\title{
Dot
}

DOE/NASA CONTRACTOR

REPORT

\section{SOLAR HEATING SYSTEM INSTALLED AT JACKSON, TENNESSEE - FINAL REPORT}

Prepared from documents furnished by

Energy Solutions, Incorporated

5575 Poplar Avenue, Suite 612

Memphis, Tennessee 38117

Under DOE Contract EG-77-A-01-4092

Monitored by

National Aeronautics and Space Administration

George C. Marshall Space Flight Center, Alabama 35812

For the U. S. Department of Energy

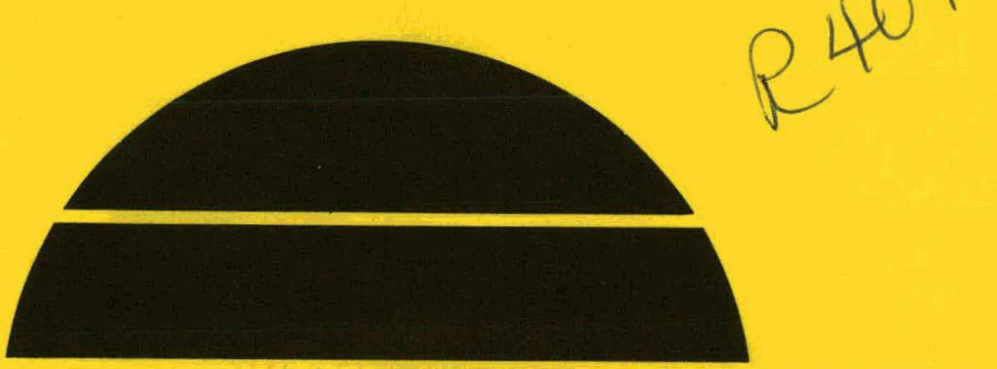

\section{U.S. Department of Energy}




\section{DISCLAIMER}

This report was prepared as an account of work sponsored by an agency of the United States Government. Neither the United States Government nor any agency Thereof, nor any of their employees, makes any warranty, express or implied, or assumes any legal liability or responsibility for the accuracy, completeness, or usefulness of any information, apparatus, product, or process disclosed, or represents that its use would not infringe privately owned rights. Reference herein to any specific commercial product, process, or service by trade name, trademark, manufacturer, or otherwise does not necessarily constitute or imply its endorsement, recommendation, or favoring by the United States Government or any agency thereof. The views and opinions of authors expressed herein do not necessarily state or reflect those of the United States Government or any agency thereof. 


\section{DISCLAIMER}

Portions of this document may be illegible in electronic image products. Images are produced from the best available original document. 
NOTTCE

Th1s report was prepared to document work sponsored by the United States Government. Neither the United States nor 1ts agents the United States Department of Energy, the United States National Aeronautics and Space Adminfstration, nor any federal employees, nor any of their contractors, subcontractors or their employees, make any warranty, express or implied, or assume any legal liab1l1ty or responstb1l1ty for the accuracy, completeness, or usefulness of any information, apparatus, product or process disclosed, or represent that 1ts use would not Infringe privately owned rights. 
TECHNICAL REPORT ST ANDARD TITLE PAGE

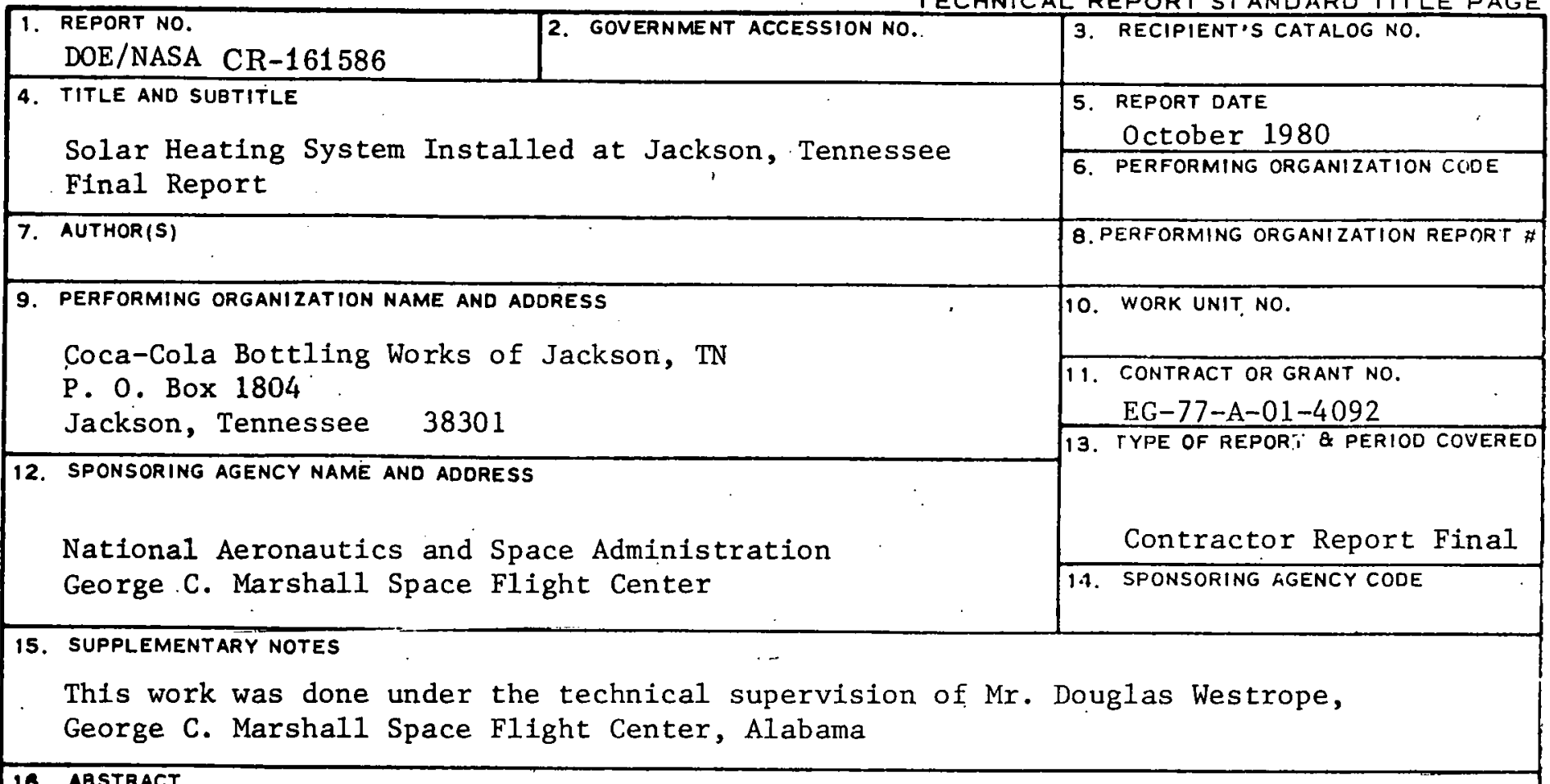

16. ABSTRACT

This final report describes the solar energy heating system installed at the Coca-Cola Bottling Works, in Jackson, Tennessee. The solar components were partly funded by the Department of Energy under Grant EG-77-A-01-4092, and the technical management was done by NASA/George C. Marshall Space Flight Center, Alabama.

The system consists of 9480 square feet of Owcns Illinuts evicuated cubular solar collectors with attached specular cylindrical reflectors and will provide space heating for the 70,000 square foot production building in the winter, and hot water for the bottle washing equipment the remainder of the year.

\begin{tabular}{|c|c|c|c|}
\hline 17. KEY WORDS & & $\begin{array}{l}\text { 18. DISTRIBUTION STATEMENT } \\
\text { Unclassified-Unlimited } \\
\text { WILLIAM A. BROOKSBANK JR. } \\
\text { Mgr., Solar Energy Applicatic }\end{array}$ & ons $-59 a$ \\
\hline $\begin{array}{l}\text { 19. SECURITY CLASSIF. (of thle roport) } \\
\text { Unclassified }\end{array}$ & $\begin{array}{r}\text { 20. SECURITY CLAS } \\
\text { Unclas }\end{array}$ & \begin{tabular}{|l|c|} 
if. (of thle pago) & 21. NO. OF PAGES \\
if ied & 143
\end{tabular} & $\begin{aligned} \text { 22. } & \text { PRICE } \\
& \text { N. TIS }\end{aligned}$ \\
\hline
\end{tabular}


THIS PAGE

\section{WAS INTENTIONALLY LEFT BLANK}




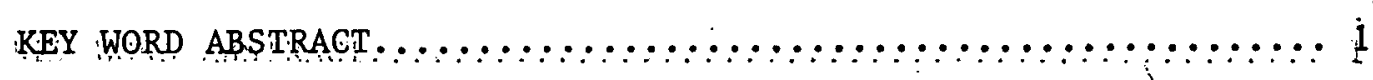

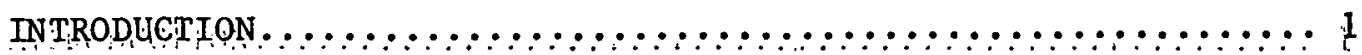

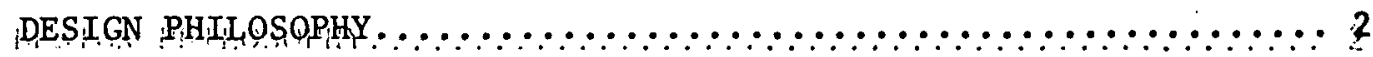
PROBLEMS ENCQUNTERED AND SRT

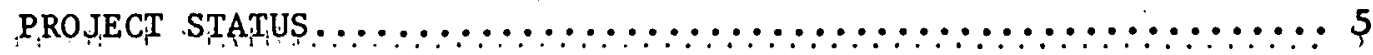
APPENDIX $\Lambda$ ACCEPTANCE TESTT PLAN
APPENDIX B MAINTENANCE AND OPERATING PROCEDURES.

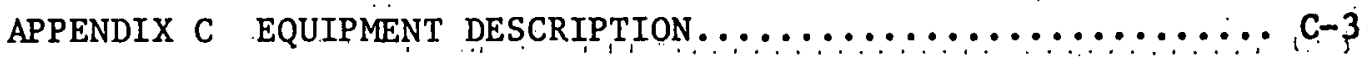

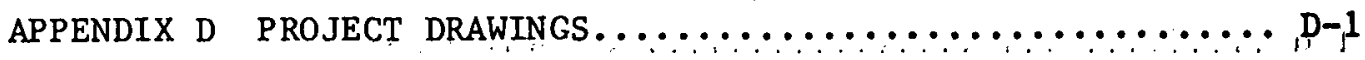


SOLAR HEATING SYSTEM FOR THE COCA-COLA

BOTTLING WORKS OF JACKSON, TENNESSEE

KEY WORD ABSTRACT

$\begin{array}{lll}\text { Application } & & \text { space and wacer heating } \\ \text { System Type. } & - & \text { active } \\ \text { Collector Type } & - & \text { hydronic evacuated tube } \\ \text { Collector Manufacturer } & - & \text { Owens-Illinois } \\ \text { Collector Area } & - & 9480 \mathrm{sq} \text {. ft. net } \\ \text { Stolage Capacity } & - & 24,000 \mathrm{gallons} \\ \text { Building Load } & - & 5001 \times 10^{6} \mathrm{BTU} / \mathrm{YR} \\ \text { BTU's Produced } & - & 2765 \times 10^{6} \mathrm{BTU} / \mathrm{YR} \\ \text { Building Owner } & - & \text { Coca-Cola Bottling Works } \\ & - & \text { of Jackson, Inc. } \\ \text { Designer } & - & \text { Energy Solutions Inc. } \\ \text { Contractor } & - & \text { Morgan \& Turner, Inc. }\end{array}$

INTRODUCTION

A retrofit solar heating system has been designed and installed at the Coca-Cola Bottling Works in Jackson, Tennessee. The system consists of 9480 square feet (net) of Owens-Illinois evacuated tubular solar collectors with attached specular cylindrical reflectors and will provide space heating for the 70,000 square foot production building in the winter and hot water for the bottle washing equipment the remainder of the year.

It is anticipated that the solar heating system will supply an estimated $55 \%$ of the present total thermal load at the bottling plant. 
It was originally envisioned that flat plate collectors would be used for the system, but the evacuated tubular collector was ultimately chosen because it offered greater potential for possible higher temperature applications at the plant (e.g. process cooling and air conditioning) in the future.

Figure 1 presents a schematic of the final system design. A total of 346 collector modules comprise the solar collector array which faces virtually due south and is tilted $50^{\circ}$ from the horizontal. The steep tilt angle for this year-round system is due to the high space hearing load in the winter months ( $900 \times 106 \mathrm{BTU} / \mathrm{MO}$ ) compared to the much lower process hot water load in tue summer ( $\left.200 \times 10^{6} \mathrm{BTU} / \mathrm{MO}\right)$.

Storage is provided via two (2) 12,000 gallon steel tanks located within the bottling plant's production bullding. The somewhat higher than normal storage volume-to-collector area ratio $\left(2.5 \mathrm{GAL} / \mathrm{FT}^{2}\right)$ is required because of the four-day work week employed at the plant. Thus; energy is collected seven days a week but is used primartly only four days a week.

Space heating from storage occurs via sixteen (16) hydronic unit heaters located throughout the production bullding. Four shell-and-tube heat exchangers transfer stored heat from the tanks to the bottle washer.

The collector pump is activated whenever a pyranomecer in the plane of the collectors measures a solar insolation above some threshold (e.g. $50 \mathrm{BTUH} / \mathrm{FT}^{2}$ ). To minimize pump cycling, a time-delay arrangement keeps the pump on a minimum of 30 minutes (adjustable) once it is activated. Over-temperature protection is provided via the purge coll chrough which collector return water is diverted whenever the return temperature exceeds $235^{\circ} \mathrm{F}$. The heat from the purge unt is directed to the outdoors in the summer and to the indoors during the heating season. The collector pump is activated for 30 minutes every four hours to supply freeze. protection whenever the outdoor temperature is below $35^{\circ} \mathrm{F}$.

Because the existing roof structure was unable to support the collector array with an acceptable margin of safety, a super-structure tied to the vertical columns of the bullding was designed and Installed above the roof using standard steel structural members.

Figure 2 presents the predicted thermal performance of the system along with the combined space and water heating loads of the bottling works. As can be seen, with tile exception of a couple of summer months, virtu- 


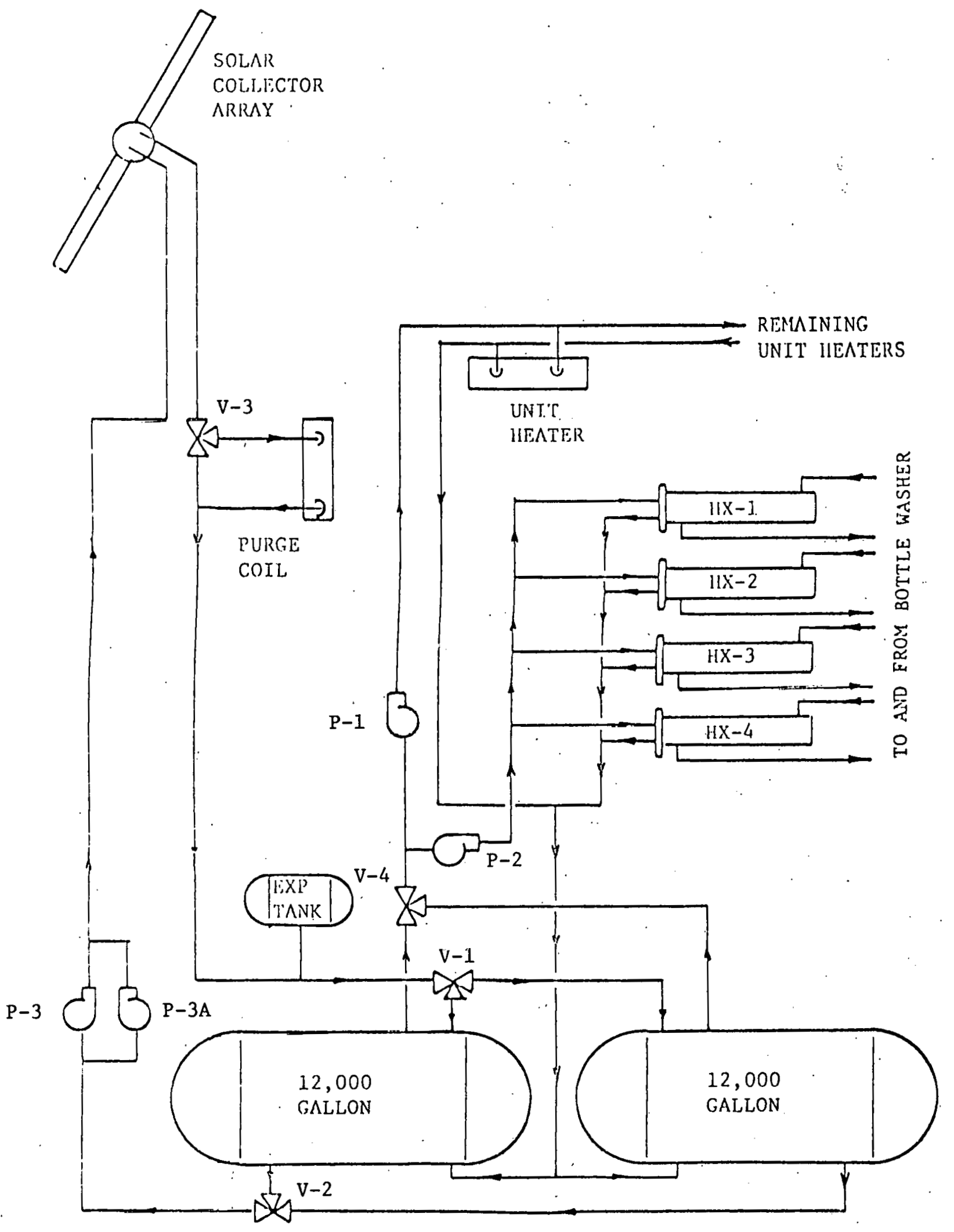

FTGURE 1. SCHHMATIC OF SYSTEM 
ally all of the collected energy can be used by the plant.

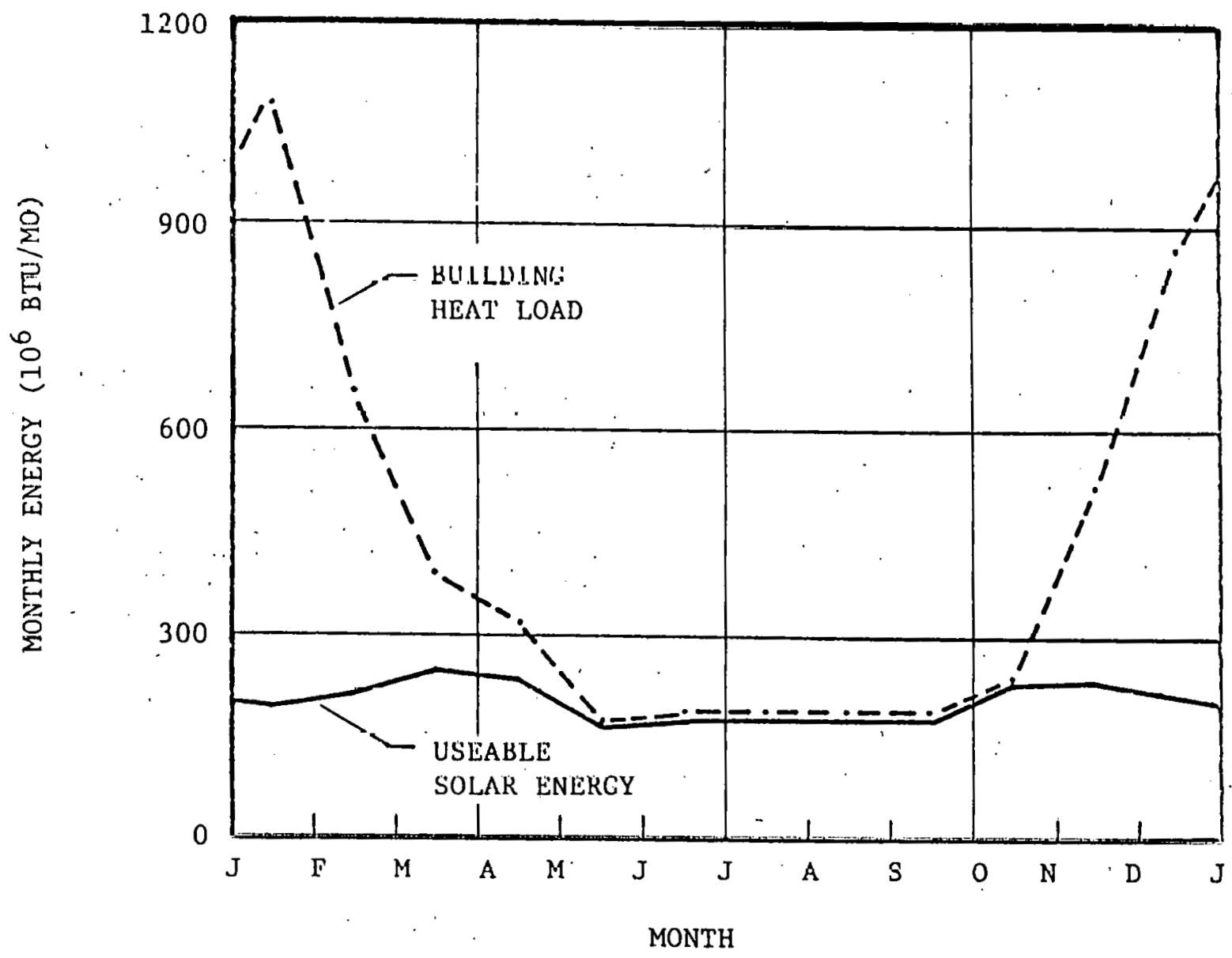

FIGURE 2. SYSTEM PERFORMANCE PREDICTION

PROBLEMS ENCOUNTERED AND SOLUTIONS.

The two major problems that led to project delays both concerned changes in solar collectors. The first concerned the request to change from the originally proposed flat plate collector to the evacuated tubular collector. Approximately three months elapsed before approval of this request was given. 
The second delay occurred after the final design review when the collector manufacturer urged that the project use a drainable version of its collector. After much discussion and approximately four months delay, it was decided to use the non-drainable collector originally envisioned.

No major problems occurred during the construction phase of the project which commenced in January, 1979 and ended in September, 1979. A virtually flawless start-up occurred in September, 1979 followed by a "shakedown" period during the ensuing fall. The only problems encountered during this last phase have been relatively minor problems associated with the control system. These problems are presently being reviewed by the controls sub-contractor in hopes of finding a solution forthwith.

$\underline{\text { PROJECT STATUS }}$

As discussed above the system has been in continuous operation since early September, 1979. With the exception of the aforementioned controls problem, the system appears to be operating satisfactorily.

At present data are being gathered to ascertain the system performance characteristics and to compare them with those predicted by the design analysis. 


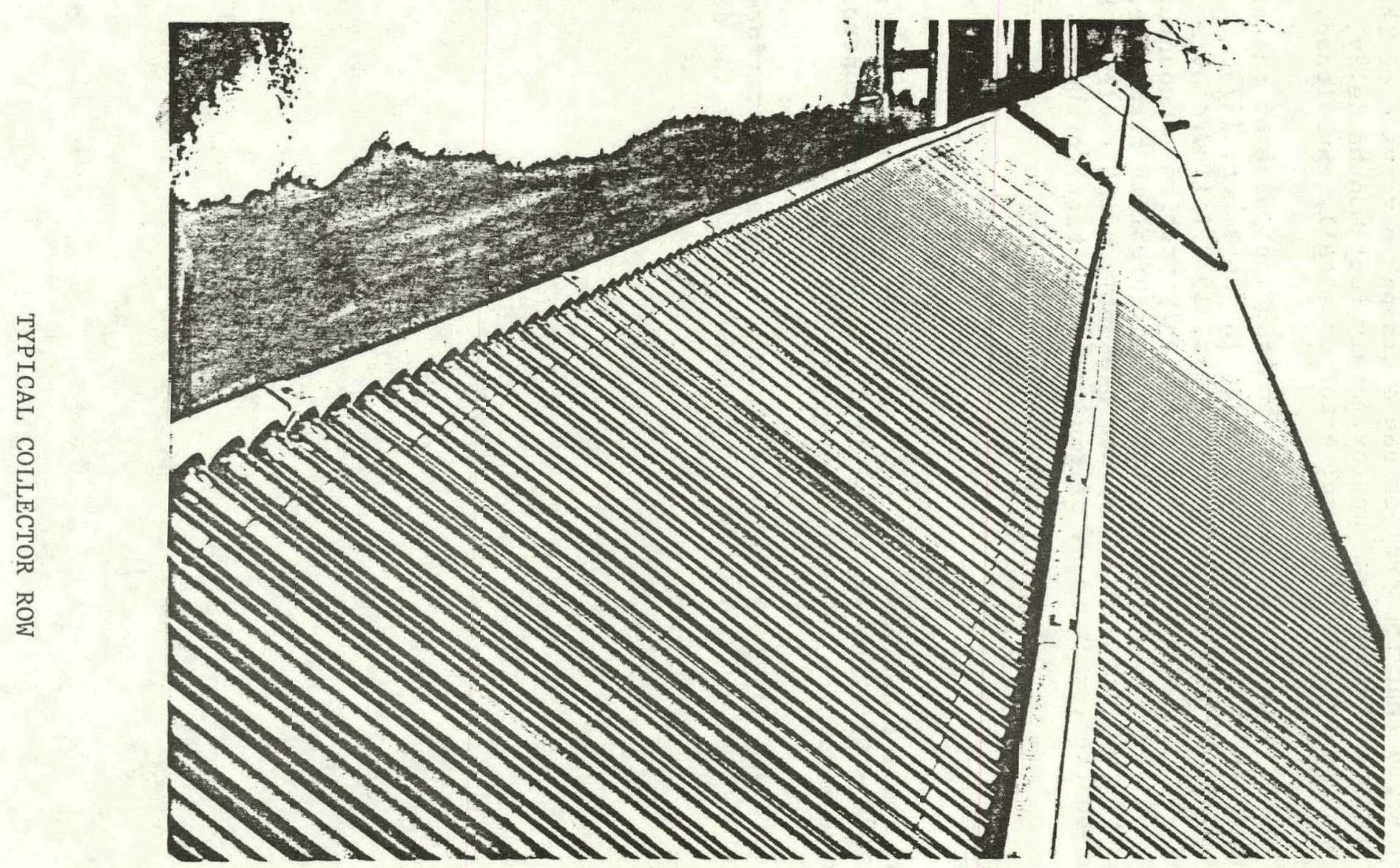


APPENDIX A

ACCEPTANCE TEST PLAN

A-1 
PROJECT NAME:

PROJECT LOCATION :

DATE OF TEST:

INSPECIOR :
Coca-Cola Bottling Works of Jackson, Inc. Jackson, Tennessee

September 20,1979

T. COILECTTON SUB-SYSTIM

$\Lambda$. Verify that solar collectors are those called for and that the number of collectors is that called for in the plans and specifications.

COMMENTS : Owens-Illinois Tubular Collectors installed

- B. Verify that collector orientation is that called for in the plans. COMMEN'TS : Collectors are slightly off due south $4^{\circ}$ west of south

c. Verify that collector-loop pump is that called for it plans. COMMENTS : Verified

D. Verlfy that pressure relief valves of the rating called for in the plans are installed at each collector array between any shut-of $f$ valve:s.

COMMIN'IS: $\quad$ Verified

li. Verily that cullector fluid is a water/ethylene glycol mixture with a freezing point below $-20^{\circ} \mathrm{p}$.

Commlin'ts: The system is using water with a pump mode

for freeze protection. 
b. Verity that collector loop caln malintajn a pressure of 30 psifg for 1.5 minures with no leaks occuring. If relief valves are: remesvel, carce should be taken to insure that solar collectors do not overlicilt.

COMMEN'J'S: System was pressure tested to 100 PSIG

hydrostatic pressure for 24 hours and no

leaks were found.

C. With collector pump operating, adjust "circuit-setter" valves at aich collector array to provide schedule flow rate through each array.

COMMEN'IS: Circuits were balanced

H. With collector pump operating and with clear skies prevailing, record the system performance via the below table. Fluid temperatures shal.l be taken with thermometers mounced in the collector supply and return lines as near the collector array as possible. Insolation measurements shall. be made with a solar pyranometer in the plane of collector. Array \#.l. 


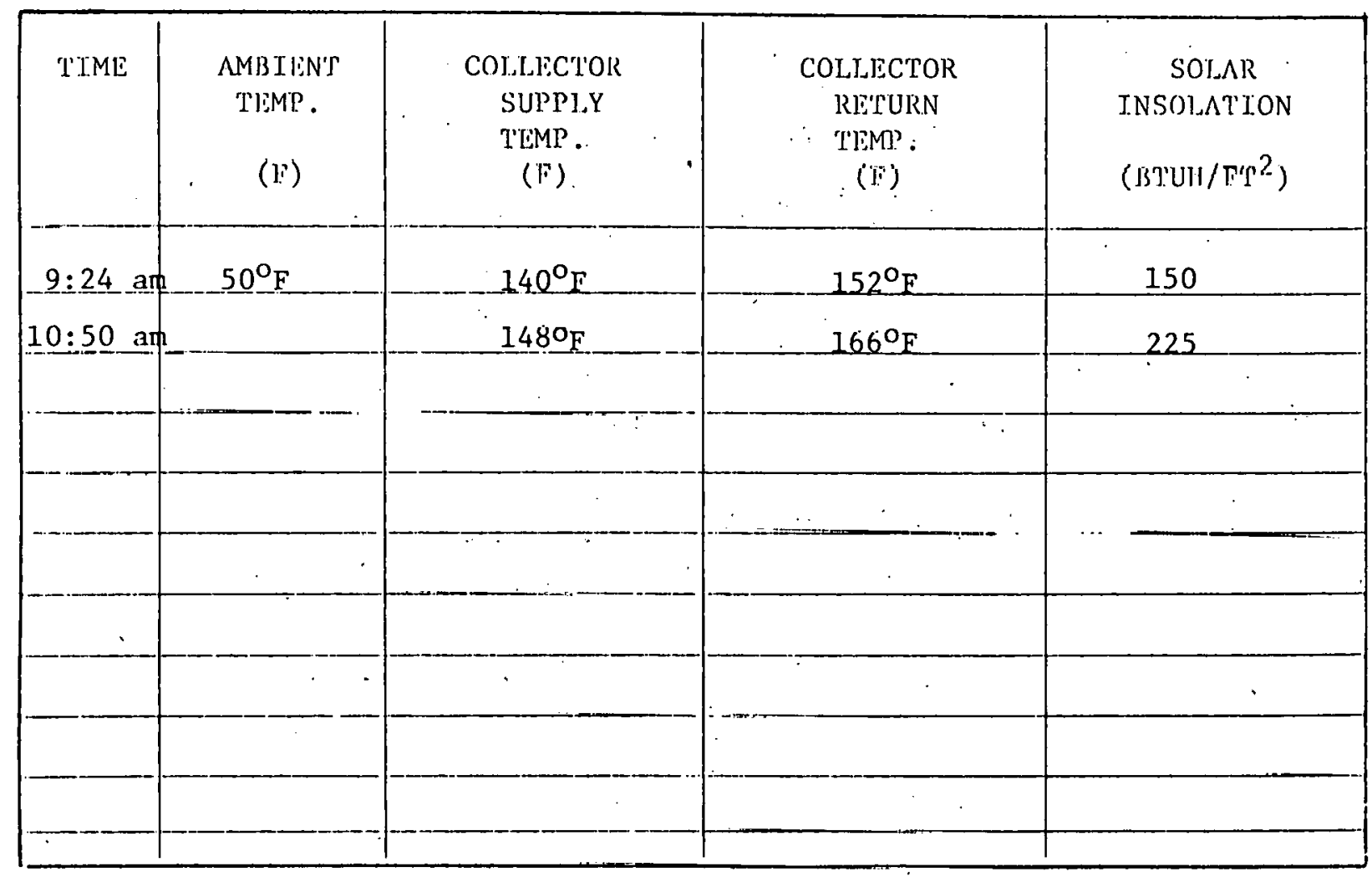

COMMLNT'S: _ Data taken on November 7, 1979 
I.I. HEAT DISSIPATION SUB-SYSTEM

A. Verify that purge unit is that called for in the plans or note any exceptions. Verify that unit is installed as shown in the plans.

COMMENTS :

Purge air unit measured amp $25-24-25$

B. Verify that whenever storage tank temperature exceeds a given (adjustable) set-point that flow returning from the collector array is diverted through purge unit.

COMMENTS :

Verified

C. With storage tank temperature above $180^{\circ} \mathrm{F}$ and with a solar insolation level above $200 \mathrm{BTUH} / \mathrm{FT}^{2}$ in the collector plane, verify that flow returning to tank heat exchanger via the purge coil is at a lower temperature than flow leaving the tank heat exchanger.

COMMENI'S: Purge unit operation was simulated and found to operate properly

III. STORACE SUB-SYSTEM

A. Verify that main storage tank and all related hardware are as specified in the plans. Verify that tank carries an ASME seal.

COMENTS: Verified 
A. Verify that the pump, piping, valves, heat exchangers, insulation and related components are in accordance wath the plans or note any exceptions.

COMMIIN'S : Verificied

B. Verify that solar collertor pump starts whenever the collector temperature exceeds the miatin storage temperature by $20^{\circ} \mathrm{p}$ and remilins on until this tomperature difference falls to less than $3 \%$.

COMMIINTS: Solir pump is started by pyronometer.

C. Verify that whenever main storage tank temperature exceeds a given set point (nominatly $240^{\circ} \mathrm{F}$ ) and collector pump is on, the llow returning from the collectors is diverted through the purge coil via the two-position motirized valve and that purge coil fan i.s simultancously activatied. Verily that this condition prevails unti. tamk temperature drops to at least $2^{\circ}$ below the given set point.

COMMlints: Condition was simulialed and verified

1). Verifiy that whenever the building's thermostat calls for space heat and the malin storage tank temperature is above a given set point (nominally $100^{\circ}$ i) rhe spatce hearing pump is activated and that the air-handing unit is activated simultancously.

COMMIN'I'S: Simulated 
1. Verily that tank dritin value and sight gage are operalive,

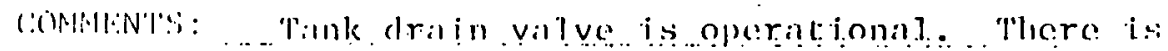
a sight gage on expansion tanks

C. Verjfy that tank is equipped with a pressure relijef villve as shown in the pilans.

COMMIENIS:

Verified 


\section{THIS PAGE \\ WAS INTENTIONALLY \\ LEFT BLANK}




\section{APPENDIX B}

MAINTENANCE AND OPERATING PROCEDURES

B-1 
EQUIPMENT FUNCTIONS

SOLAR HEA?ING PROJECT

COCA-COLA BOTTLING WORKS OF JACKSON, INC.

JACKSON, TLNNESSEE.

\section{Solar Collectors}

A total of 346 Owens-Illinois solar collectors are installed on the roof of the building. These collectors are of glass construction and must be protectac? against freezing and from excessive pressure. Water must be circulated thru the collectors or they must be drained whenever solar heat from the sun is available or in the event the outdoor temperature is below $35^{\circ}$. It is very important that water be circulated when solar heat is available as the heat build-up can occur very quickly, thereby generating steun dul ju'essures. which will cause the tubes to explode. Individual relief valves have been installed at each array of collectors to protect against high pressirie. These valves should not be depended upon for protection of the collectors except in the case of an emergency. In the event maintenance is required on a collector, the work should preferably be done on a cloudy day so as to minimize the chance of pressure build-up.

In the event it is necessary to drain the water from the collectors, they must be vented as they are filled to purge all air out of the tubes and assure a filled condition. The circulation tubes within the collector's are quite small and the least amount of air can be trapped in the tubes and block the water flow. This blockage of water flow would then result in a high pressure as soon as sunlight. was available and possibly cause damage to the collectors. Venting may be accomplished thru the individual tubes and also thru a manual air vent located at the pipe connection to each array.

It will be necessary to periodically clean the collector tubes and particularly the reflectors. We do not have a recommended schedule for this, the surfaces should be checked and maintained in a clean condition. 
2. Hot Water Unit Heaters

A total of 16 McQuay downflow hot water unit heaters have been installed for building heat. These units are controlled by wall mounted electric thermostats and manual starters. Each thermostat is equipped with a manual "Fan-On" switch which permits operation of the fan for air circulation.

3. Hot Water Circulating Pumps

A total of 4 centrifugal pumps provide all water circulation for the system. These pumps are automatically controlled so long as the starter selector. switch is in the "AUTO" position. The function of each pump is as listed below:

P-1 Circulation of hot water thru the McQuay unit heaters.

P-2 Circulation of hot water thru the 4 heat exchangers which serve the bottle washer.

P-3 Circulation of water thru the solar collectors.

P-3A Circulation of water thru the solar collectors, this is the same function and pumping circuit as P-3. NOTE: There is located at the bottom of the control panel a switch marked "P-3/P-3A", the purpose of this switch is to alternate the use of these two pumps. This switch should be re-positioned on a monthly basis so as to evenly distribute the running time between the two pumps.

\section{Water to Water Heat Exchangers}

These units are located on the floor near the bottle washer. Hot water circulated from Pump P-2 flows thm the tubes within these heat exchangers and provides a source of heat for the caustic solution used in the bottle washer. The caustic solution is circulated thru the shell of these heat exchangers and is heated by the hot water being circulated thru the tubes. Temperature control of the caustic solution is achieved by varying the water flow thru the tubes. This is accomplished by the Honeywell valves located at each 
heat exchanger. Control of these valves is discussed in the control sequence portion of this manual.

5. Watts Backflow Preventer

A series 900 Watts backflow preventer is installed in the fresh water fill connection serving the solar system. The purpose of this device is to prevent a backflow of water from the solar system into the domestic system serving the plant.

\section{Nitrogen Compressors}

Two Ingersall-Rand nitrogen compressors are located adjacent to the control panel and under the storage tank. These compressors control the system pressure so as to maintain the minimum pressure necessary for circulation thru the collectors and to prevent an excessive build-up of pressure as the heated water expands. A supply of ritrogen must be maintained in the 3 storage cylinders located to the left of the control panel as this nitrogen provides the cushion in the compression tanks. The purpose of the nitrogen is to provide a gas which will prevent oxidation within the piping system. Pressure control switches are located adjacent to the compressors and their function is described on sheet 10 of the control diagrams.

\section{Purge Air Handling Unit}

A McQuay air handling unft with a capacity of $18000 \mathrm{cfm}$ is located on a platform above the storage tanks. The purpose of this unit is to exhaust excessive heat to the atmosphere. There is no way to prevent the collectors from absorbing heat whenever solar energy is available;therefore, whenever the control system senses an excessive build-up of heat, the Purge unit fan runs and hot water is diverted thru the coil of the unit. Dampers are available in the discharge duct to direct the heated air either thru the roof or back into the building. It is very unlikely that excessive heat 
would ever be available when heat would be desired within the building;

therefore, the dampers should always be positioned for exhaust thru the roof. A chain operator has been provided to facilitate the positioning of these dampers. The selector switch on the face of the starter cover serving this unit should always be left in the "AUTO" position.

\section{Control Panel}

This panel houses the various control relays and instruments for the operation of the system. Pilot lights are provided which indicate equipment operation and in some cases alarm conditions. A description of the various lights and switches is as follows:

System Alarm - 4 lights are provided at the top of the panel and indicate high temperature alarm, outside air temperature below $35^{\circ}$, low nitrogen pressure in the storage system and low water level in the expansion tanks. In addition to the alarm lights, an audible alarm will sound in the event of an alam condition.

Display Thermometer located in the center of the panel can be used to obtain the temperature at any of the 16 points indicated by the push buttons below the thermometer. These points are as follows:

"Heating supply and return" indicates the hot water temperature being circulated by pump P-1 thru the hot water unit heaters.

"Process supply and return" indicates the temperature of the hot water being circulated by pump P-2 thru the heat exchangers.

"HX supply and return" for each of the 4 heat exchangers indicates the temperature of glycol solution entering and leaving the heat exchanger. "Compartment supply" provides an indication of the temperature of the glycol being supplied to the individual wash compartment. This may be higher than the temperature leaving the heat exchanger, indicating that the gas burner is supplementing the heat to the washer. 
In addition to the single multiple use thermometer in the center of the panel, 4 indicating thermometers are located on each side of the panel. Temperature in each storage tank is indicated by "Tank \#l" and "Tank \#2". Temperature of: the water being circulated to the solar collectors on the roof is indicated by "Solar Supply" while "Solar Return" indicates the temperature of the water returning to the tank from the solar panels. On the right hand side of the panel, 4 thermometers indicate the temperature in each compartment of the bottle washer.

Eight pilot lights located near the bottom of the panel indicate the operation of the system. Four lights to the left indicate whloh sturage tank is filling, that is obtaining heat from the solar loop and which tank is in use, that is providing heat to the process pump or the building heating system. Tlie fou: lights to the right are an indication as to whether or not the automatic control system would permit the individual burners to be used. This is not an indication that the burners are in operation only that they can operate automatically if required to maintain the desired compartment temperature.

At the bottom of the panel, selector switches are provided for Pumps P-1, P-2, P-3 and P-3A. These switches should be left in the automatic position during normal operation. The selector switch between $\mathrm{P}-3$ and $\mathrm{P}-3 \mathrm{~A}$ should be repositioned on some regular schedule, preferably monthly, so as to utilize each purm on an equal basis.

The sequence of control operation is shown on sheet \#1 of the attached control diagrams.

9. Manual Control of Evans Heaters

Occasionally it may be desirable to operate the gas fired Evans heaters separately from the solar installation. The original sensing elements have 
been left at the side of the bottle washer and must be inserted in one of the temperature wells at that point. A selector switch in front of each Evans heater should then be placed in the "MANUAL" position. Under this condition temperature of the caustic solution being circulated to the washer will be controlled directly by the gas heaters. As soon as possible, the system should be returned to a normal and automatic condition. 


\section{THIS PAGE}

\section{WAS INTENTIONALLY LEFT BLANK}


APPENDIX C

EQUIPMENT DESCRIPTIONS

C-1 


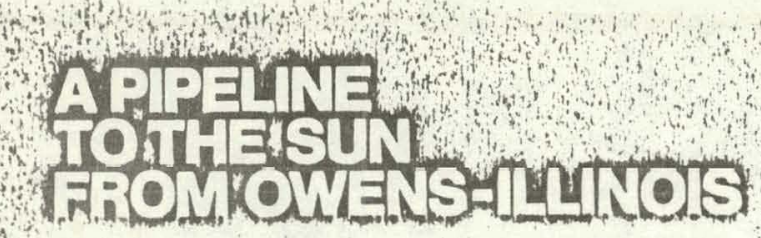

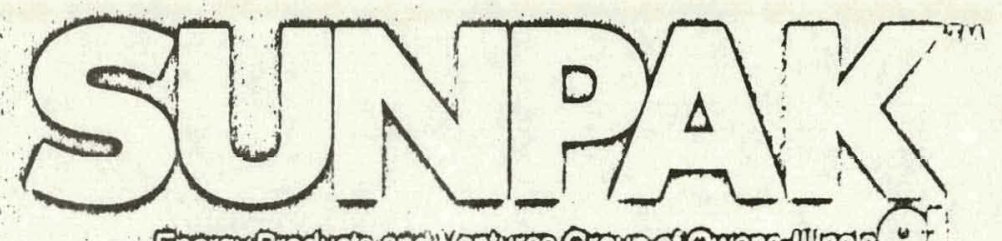

निनाकW

(F)

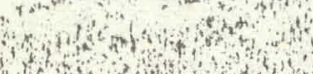

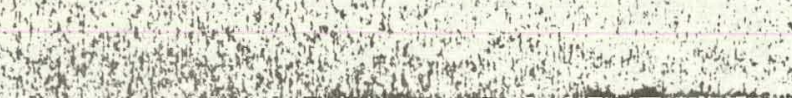

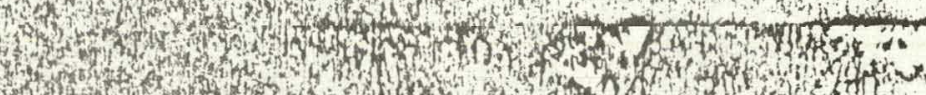

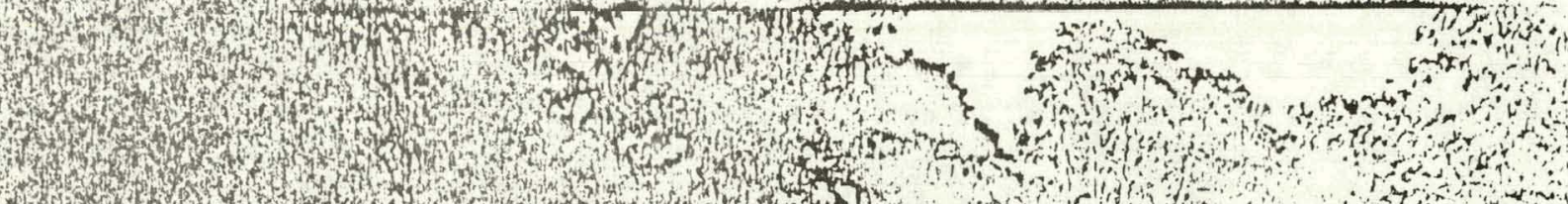
W A.

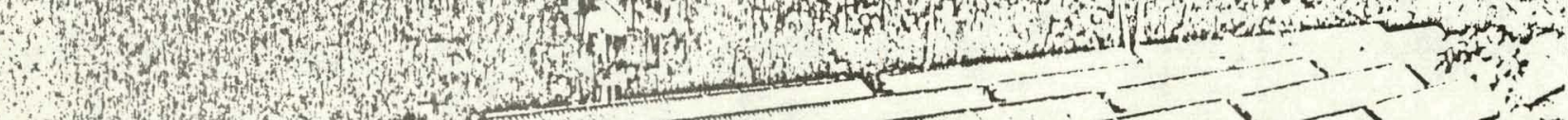

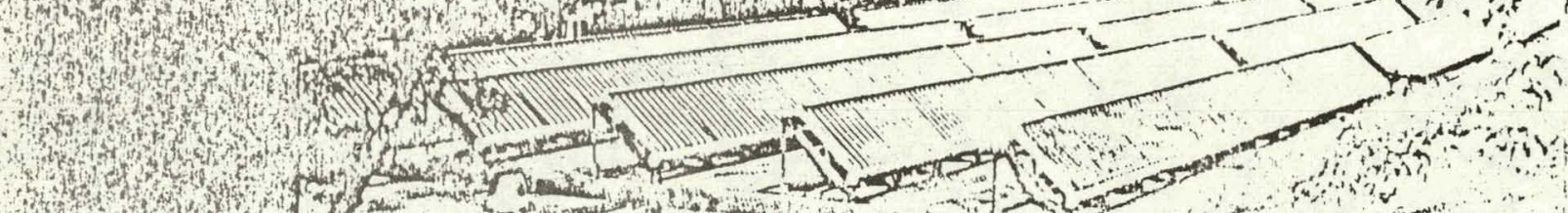

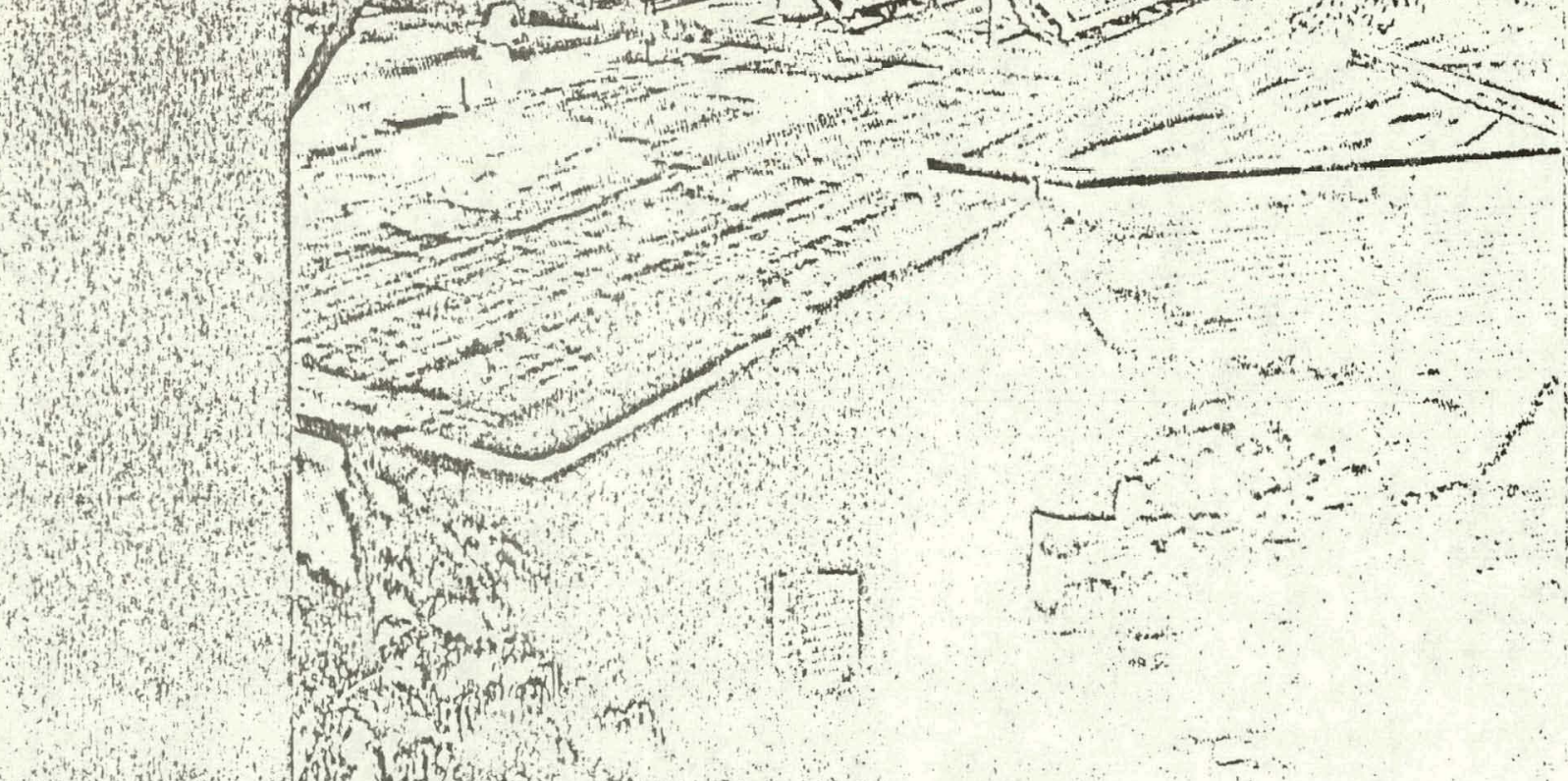

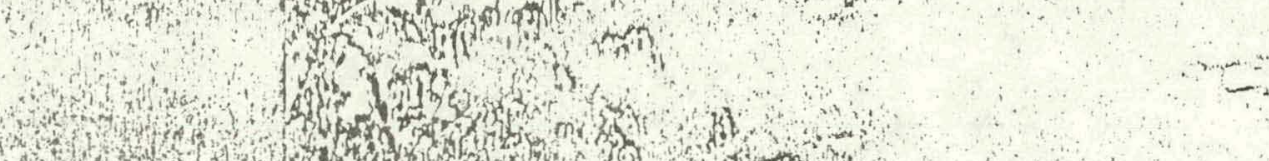

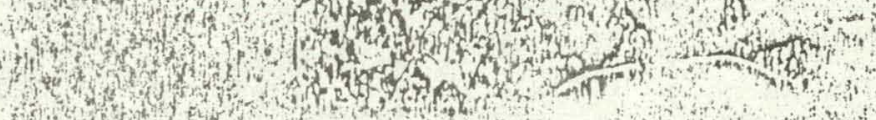

with then thent

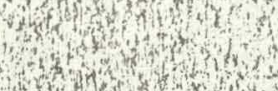

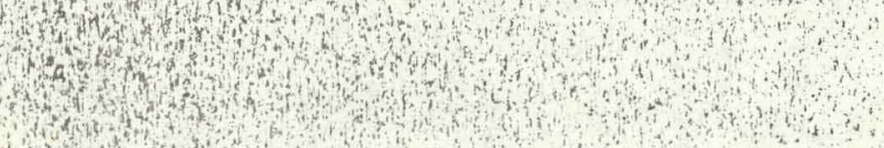

tintion

Hof 
The SUNPAK collectors described in this catalog are the most efficient solar collectors offered in the marketplace today. The following graphs show comparative test data for SUNPAK vS. flat-plate and other vacuum tube collectors based on actual independent laboratory test data*

Fig. 1: ASHRAE 93-77 test data at normal incidence for SUNPAK collectors, measured by independent lest laboratories - and shown on an aperture area busis.

Fig. 2: Incidence angle modifiers for SUNPAK collectors, measured according 10 ASHPAE 93-77 standards by independent test laboratories. For comparison. similar data is shown for both the GE evacuated tube collector and a typical flat-plate collector.

Fig. 3: All-day elficiencies of the SUNPAK colleclors, measured on an aperture died Uasis, by independent test laboratories at the indicated inlet temperatures. $I_{\text {Avt }}$ is equal 10 daily insolation-divided by the number of hours between sunisise and sunsel. Solıd lines indicate eflective daily elficiency curves derived from ASHRAE 93-77 instantaneous test clata."

Fig. 4: Comparison of ASHRAE 93-77 normal incidence efficiency curves for SUNPAK collectors, two flat-plate collectors, and the GE evacuated tube collector, all on an aperture area basis.

Fig. 5: Comparison of efluctive all-day elticiency curves for SUNPAK collectors, two liat-plate collectors, and the GE evacuated tube collector (see Fig 4). Colored regions indicate typical operating ranges for swimming pool heating. space and water heating, and air conditioning.

1 ASHRAE 93-77 TEST DATA AT NORMAL INCIDENCE

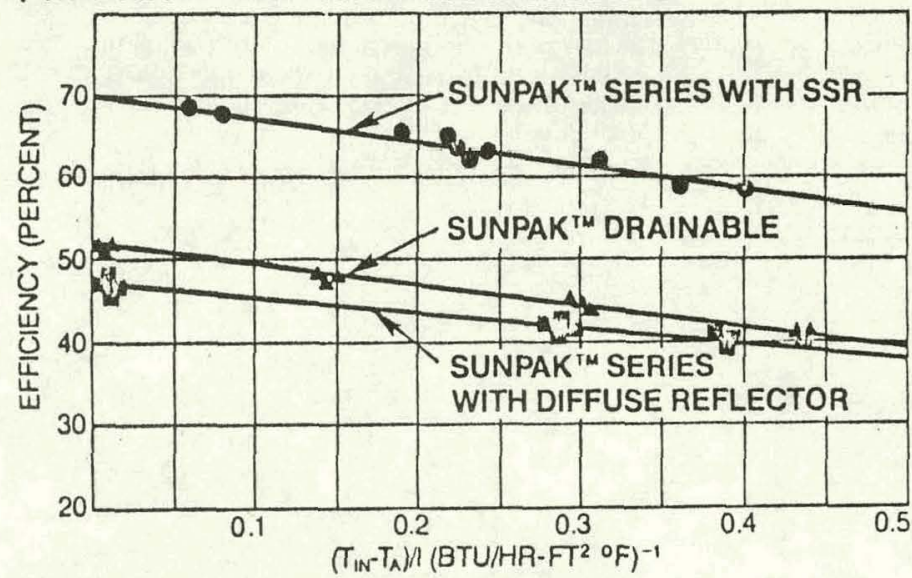

2 ASHRAE 93-77 INCIDENCE ANGLE MODIFIERS

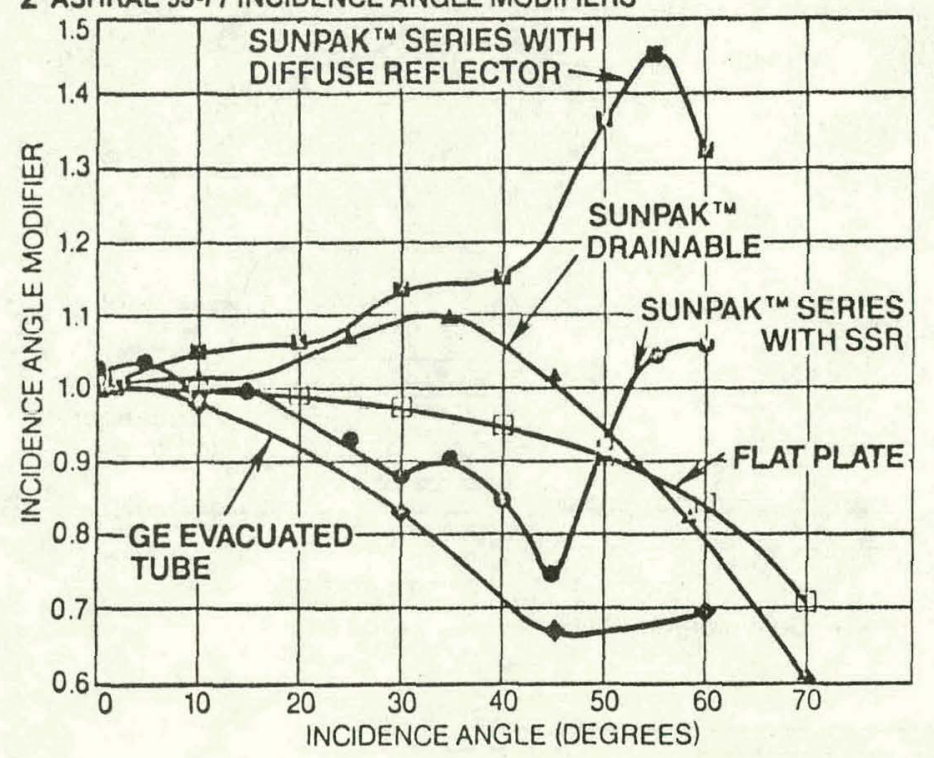

- Ficmala Sular Enurgy Cunlur and Dusurl Sunshino Exposura Tust. Inc.

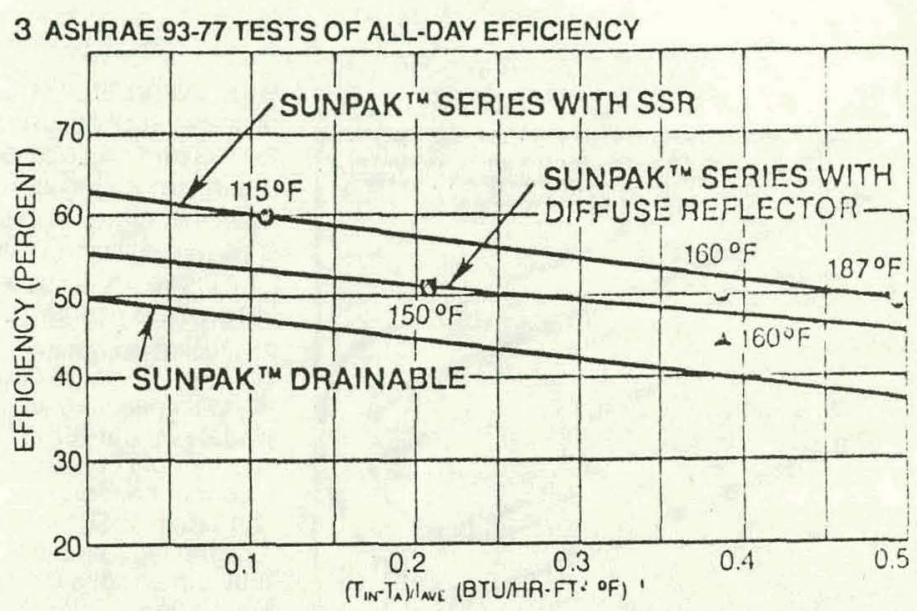

4 COMPARATIVE ASHRAE 93-77 TEST DATA AT NORMAL INCIDENCE

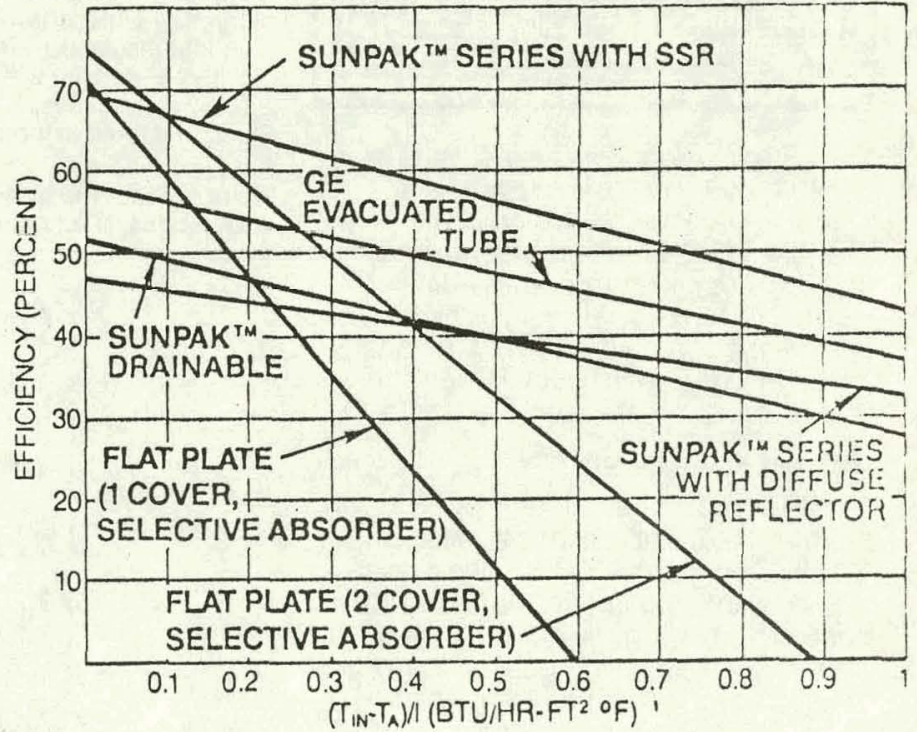

5 COMPARATIVE EFFICIENCIES ON ALL-DAY BASIS

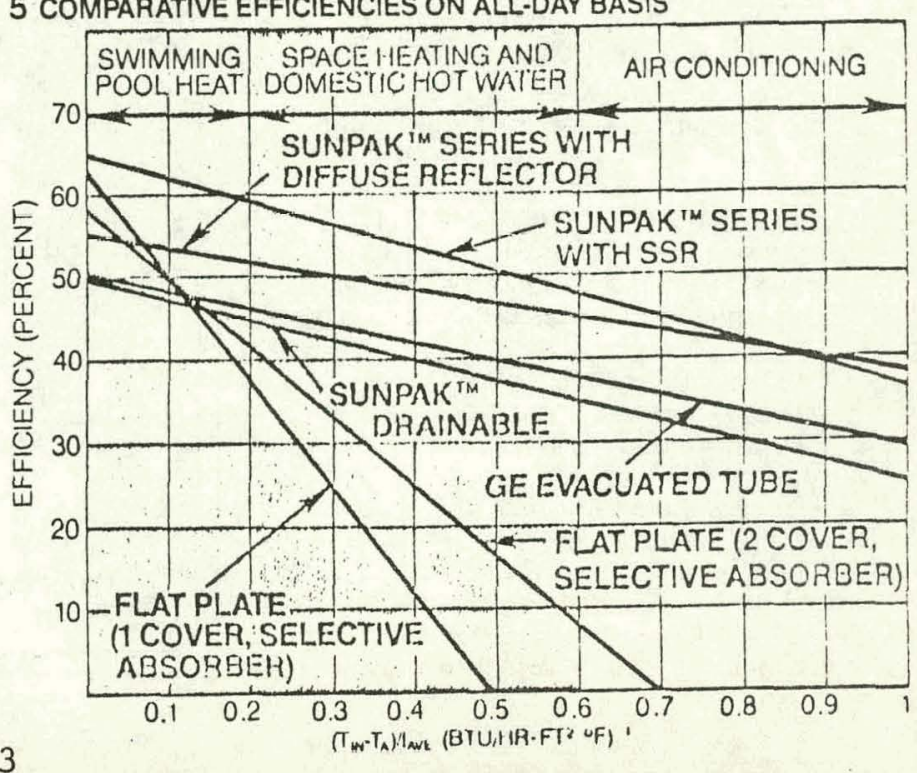




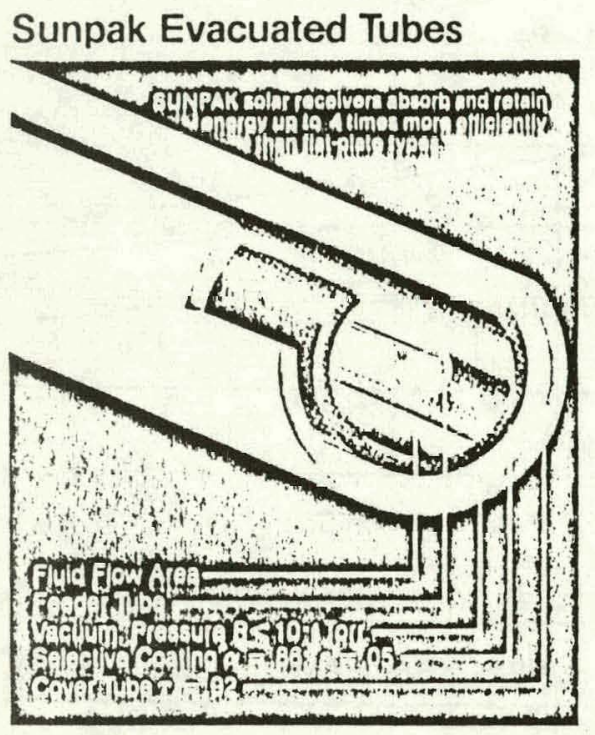

The basic component of the Owens-Illinois SUNPAK solar collector system is a hermelic package consisting of an absorber glass lube and a cover lube. The absorber lube accommodales differential thermal expansion, while a third lube permits the reverse flow path for the heat Iransler fluid. Nominal tubc dimension is $?^{\prime \prime}$ in diameter by $44 "$ long

\section{Durability and Weatherability}

SUNPAK lubes are made of low iron, low thermal expansion chemically resistant, weatherable Kimble KG-33 borosilicale glass - with a high-pertormance selective coating applied on the outside surface of the absorber lube. This coating is a semiconductor type providing absorp. lance of $\alpha=0.86, \varepsilon=0.05$.

Vacuum prolects the coaling from environmental eflects, while the vacuum ilself is protecled by a barium gelter

Exiensive life testing shows our tubes can indelinitely withstand the dry temperatures that can accompany brighi sunlight (650 $0^{\circ}$ F) Field experience and lests conducled at the Institute for Disister Research al Texas Tech Universily, also demonstrate that the tubes can withsland

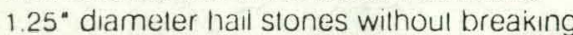

\section{Sunpak Series Collector}

A SUNPAK series solar collector consists of 24 evacualed lubes in a series flow arrangement: 12 lubes above, and 12 lubes below a centrally localed manitold A module consisting of lubes, manitold and hardware occuples an area of approximately $4^{\prime} \times 8^{\prime}$ (or 3211 ? $^{\prime}$ ). The series module is a hydronically filled non-drainable solar unit ideal for those large commercial buildıngs or industrial process applications where there's a reed for maximum solar collection area with minimum piping connections. Once the hydronic circuil is filled, minurnum power is required 10 circulate the solar circuit Comes ready-10-assemble, or preassembled (for large instatlations)

\section{Physical Description}

Module installation ated -32 (t? (4 fl. × $0 \mathrm{ft}$.)

Module collecting aperture $=27.4 \mathrm{ft}^{2}$

Module weight-185 lbs water filled. $110 \mathrm{lbs}$ diy.

Intermodule connections made by integral copper headers

(1.125 in. O.D. 1 in I.D.) and mechanical clamn type phenolic activated seal.

Tube dimensions (nomina!): 2 in. diameter $x$ 44 ith. long.

Recommended heat transfer fluid = water

Materials

Manifold-Hard drawn type $M$ copper tube Manifold insulation-Polyurethane foam.

$2 \mathrm{lbs} / \mathrm{ft}$. density. $\mathrm{k}=0.012 \mathrm{Btu} / \mathrm{hr} / \mathrm{ft} .{ }^{\circ} \mathrm{F}$ average thickness of 2 inches

Fluid Seals-High temperature silicone rubber.

\section{Freeze Protection}

Water, without the addition of freeze

depressants, is recommended as the heat

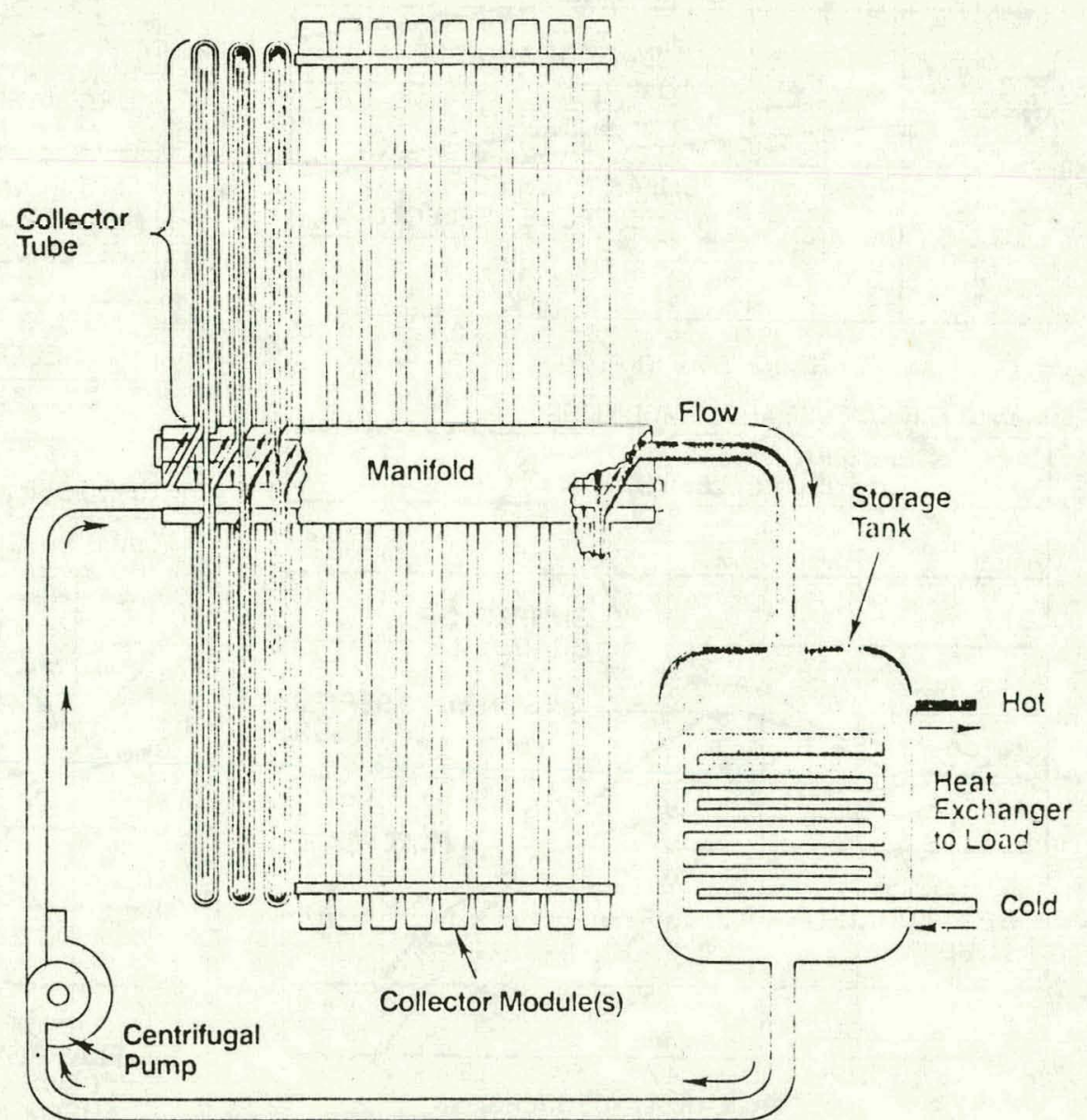

Iransfer fluids in most geographical locitions

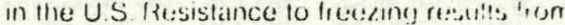
the very low thermall losses and high thislliat mass of the SUNPAK Iube: wiosi? temperatune-decily linice consilan'? is greater Inan 20 hours Periodic fluic low 'or aris! periods is recommended to protec! in'e:! outlet pipes ind connections under nethiltime: or other no-flow conditions.

\section{Operating Conditions}

Tellnel diule Relluci-minus $40^{\circ} \mathrm{F} 210^{\circ} \mathrm{F}$

Maximum oullet pressure -30 psig

Minimum pressure divis-5 issi

Tilt Ang!e-optimized tor bes! performance

Thermal Pertormance

Testing a! the Natıonal Bureay o! Standards and at Desrert Sunnshine Exposure 'ust, 'nc. in addition to ex!ensive in-house Durtormaince tests, verifles !he lag!!-pel luman!lue leat dit." of the SUNPAK colleclor in pan!:culat. SUNPAK's ability 10 de'tver usotul energy throughout in entire daly has been (tementhstrated for both high temperalures $\left(T_{114} \geqslant 200^{\circ} \mathrm{F}\right)$ and cold cloucly wuither conditions. Since performance !es!!ng is always performed on one or more complete SUNPAK modu'es, the e!!ects of mantold and miscel'aneous heat losse's atre automaticat!y ncluded in the :es! cilli 
Series Collectors

Shown: the basic dimensions and support structure interface of the module.
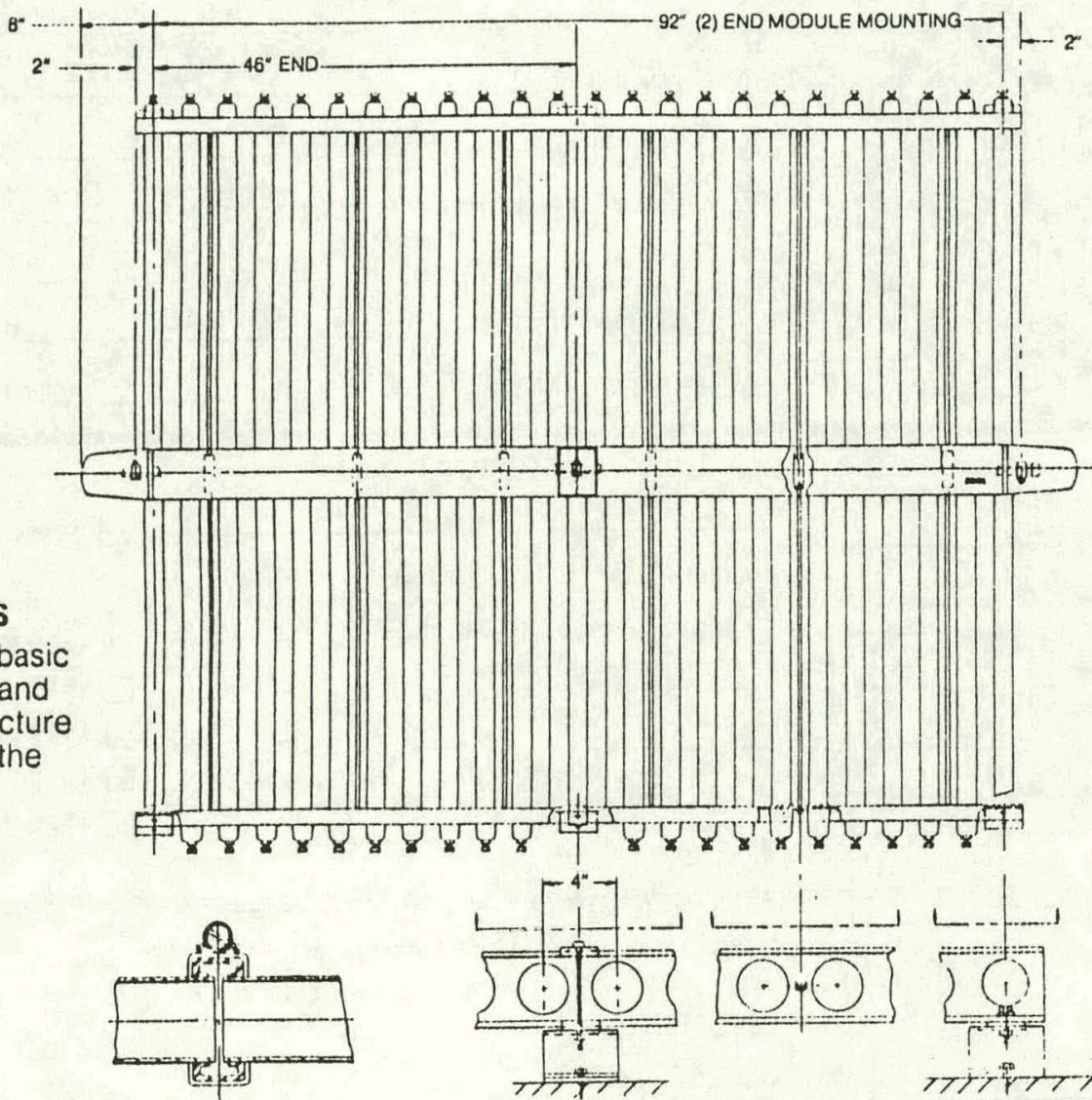

HEADER INTERCONNECTION
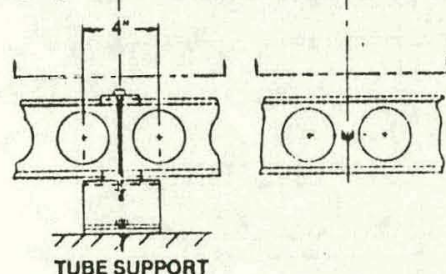

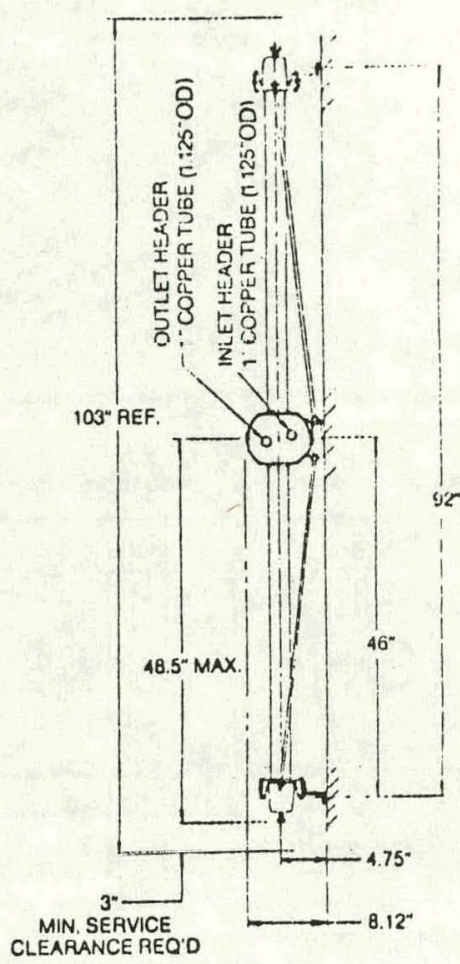

CLEARANCE REO'D

$\left\{\begin{array}{l}(1) \\ i=x+y\end{array}\right.$

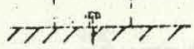

END TERMINATION

\section{Drainable \\ Collector \\ Module}

Shown: the basic

components and the

pre-assembled

package as it

interfaces the

support structure.
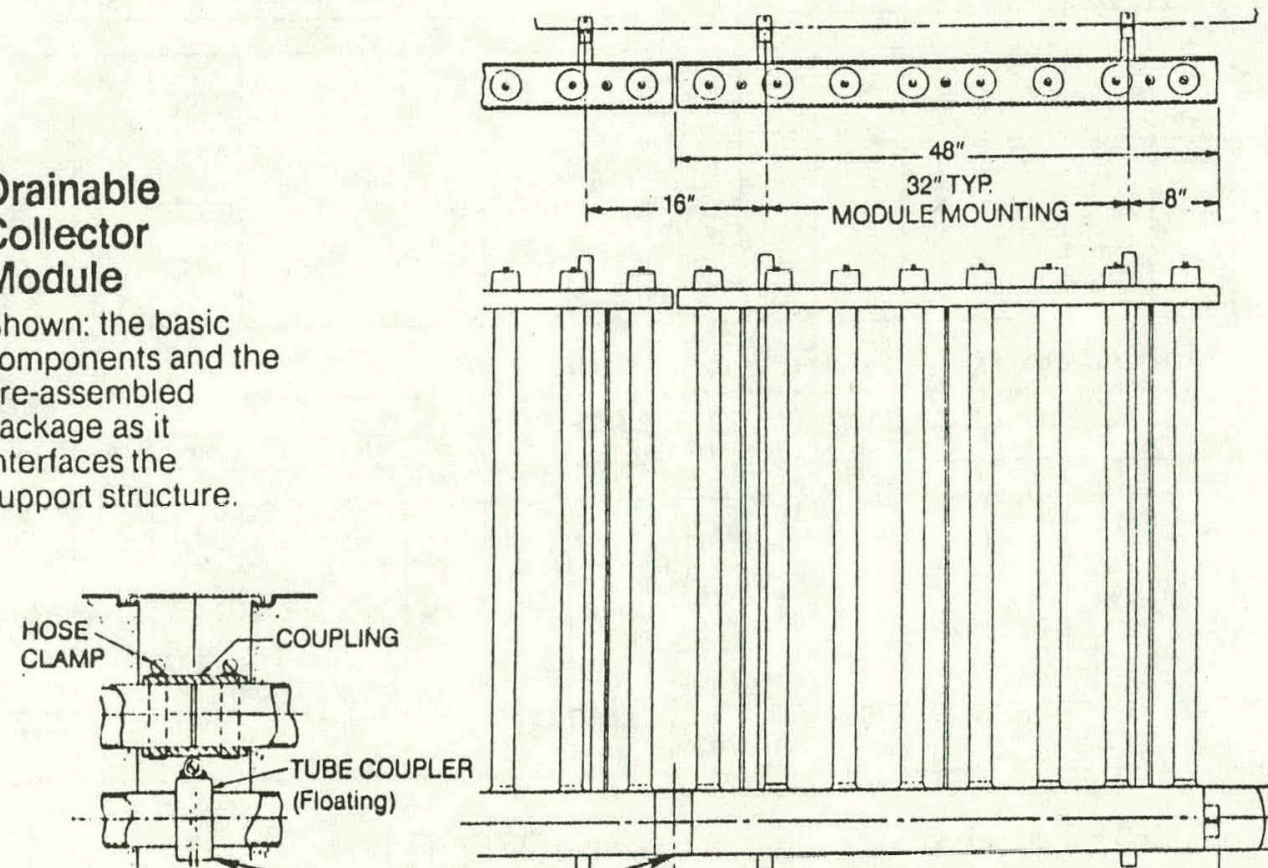


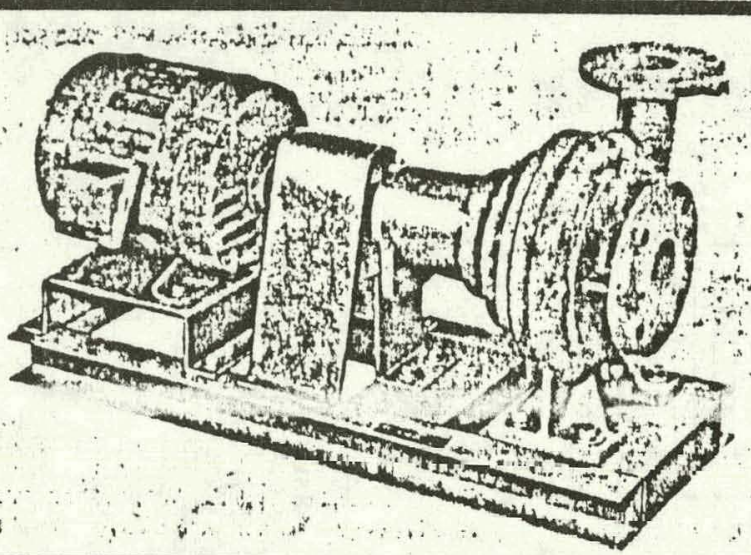

јов Coca-Cola Jackson, TN
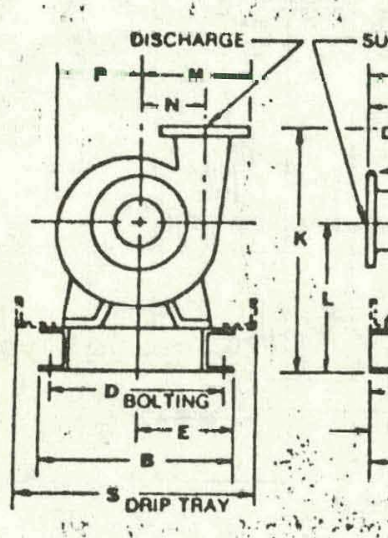

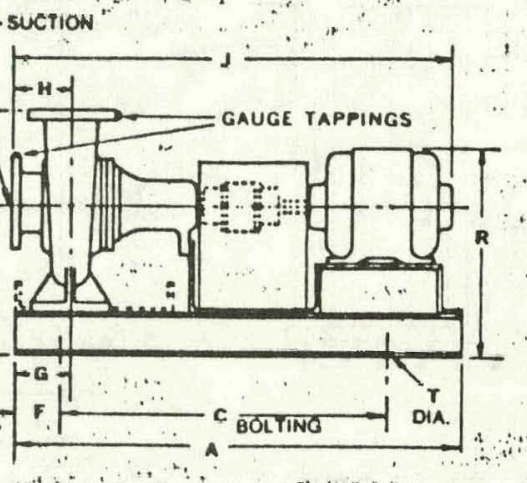

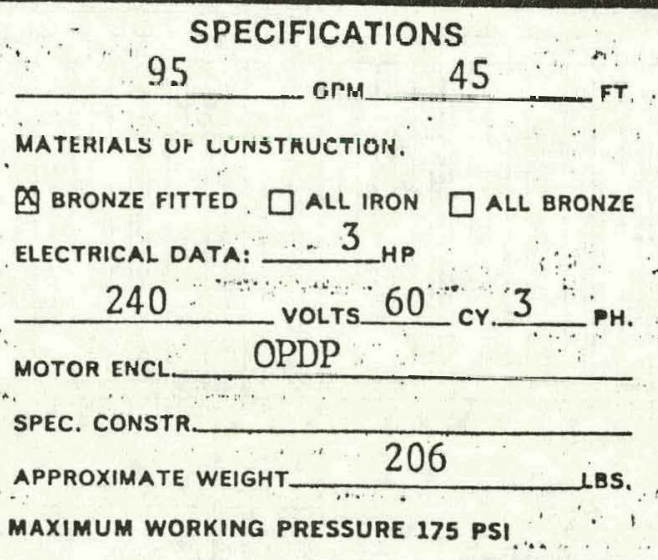

DIMENSIONS

FLANGES ARE $125+$ A.S.A.
UNIT TAG NO., $\mathrm{P}-1$

ENGINEER

Griffith C. Burr

Morgan \& Turner

B \& G REPRESEnTATIVE Johnson \& Scott

1252

suвmitted вr Gene Mankowski DATE $12-6-78$

I APPROVED BY

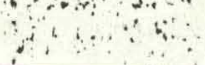

STANDARD SEAL 1510

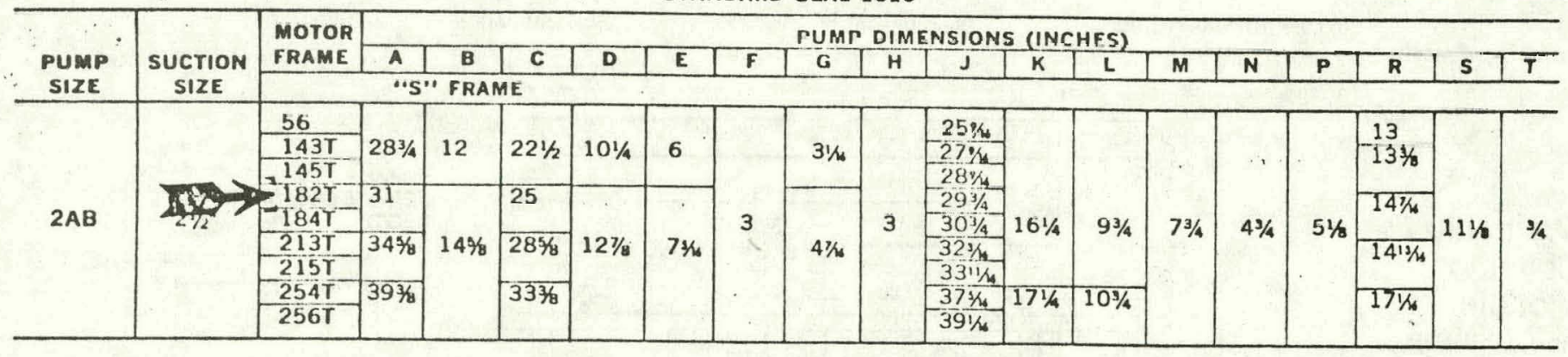

STUFFING BOX 1510-P, 1510-PF, 1510-S, 1510-D

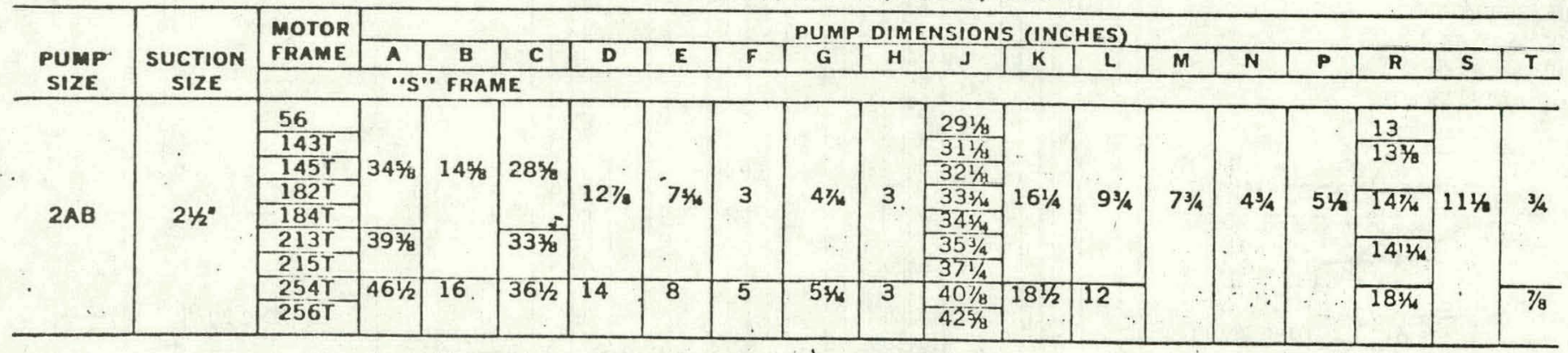

BELL \& GOSSETT mORTON GROVE, ILL. 60053 Tlum
Fluid Handling Division, International Telephone and Telegraph Corporation 


\section{PERFORMANCE CURVES}

Fon 2" AB cemtarueal mump ne. mo. 1510

\section{PERFORMANCE CHARACTERISTIC CURVE}

CURNES BASED ON SHOP TEST USING CLEAR COLD WATER AT A TEMPERATURE OF NOT

OVER $85^{\circ} \mathrm{F}$. PERFORMANCE IS GUARANTEED AT INDICATED OPERATING POINT ONLY.

HORSEPOWER CURVES DO NOT INCLUDE MOTOR SERVICE FACTOR.

1750
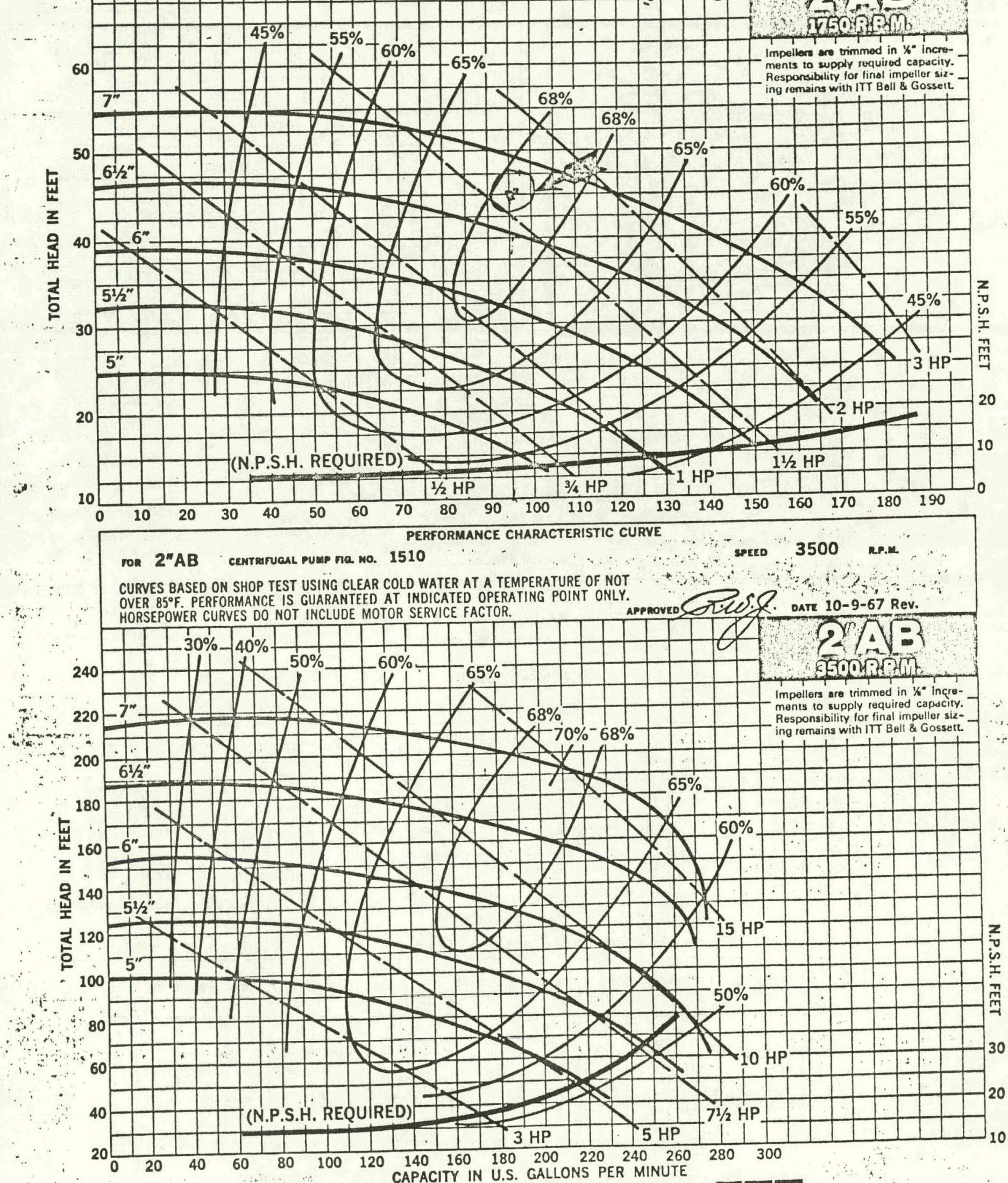


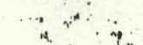

\section{Centrifugal Pumps-Base Mounted
SERIES 1510 TYPE B \\ Centrifugal Pumps - Base Mounted
SERIES 1510 TYPE B} REVISION 3 ats.
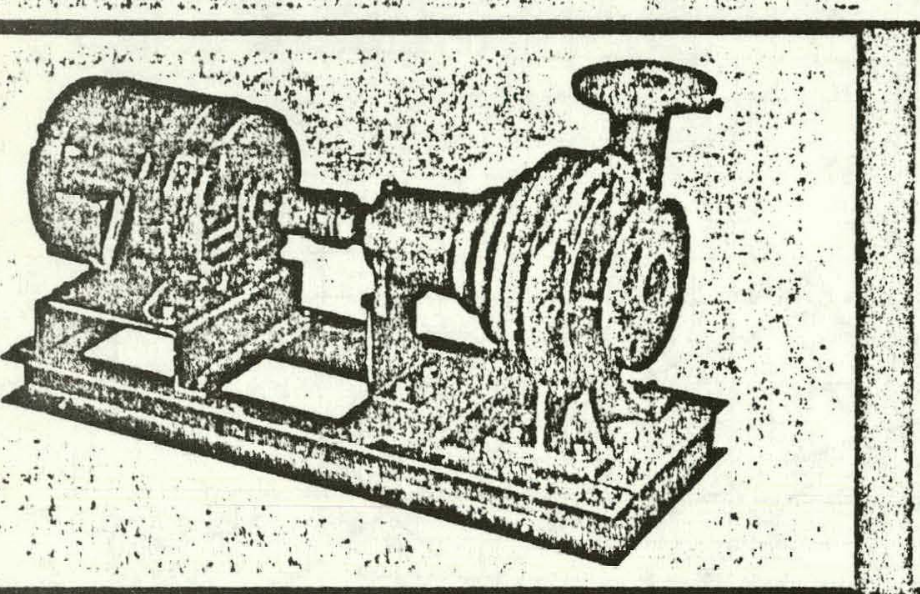

UNIT TAG NO. P-2

ENGINEER Griffith C. Burr

CONTRACTOR_ Morgan \& Turner

B \& g RePresentative Johnson \& Scott

ORDER NO.

1252

DATE

submitred ву Gene Mankowski

DATE $12-6-78$

APPROVED BY

DATE

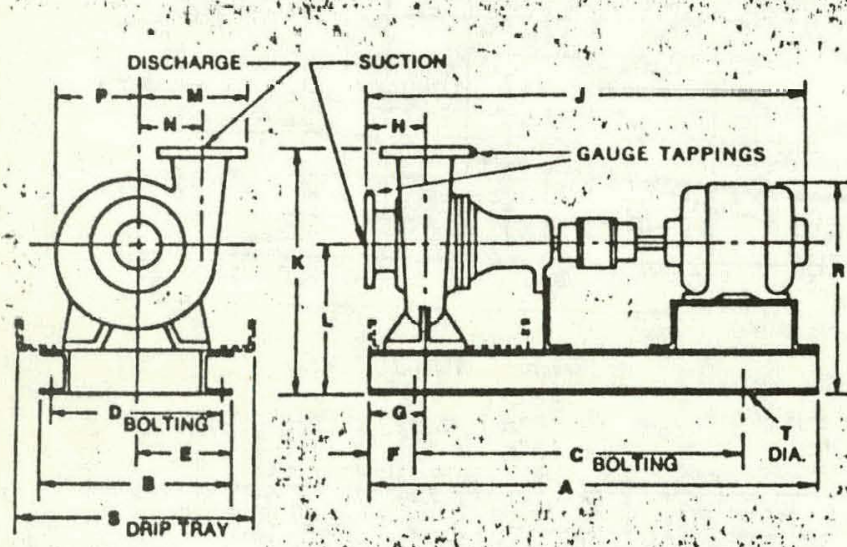

it 1 is

\begin{tabular}{c}
194 SPECIFICATION3 \\
\hline GPM 50
\end{tabular}

MATERIALS OF CONSTRUCTION:

B BRONZE FITTED $\square$ ALL IRON $\square$ ALL BRONZE ELECTRICAL DATA: 5 HP

$240 \quad$ VOLTS 60 CY. 3 PH.

MOTOR ENCL_ OPDP

SPEC, CONSTR

MAXIMUM WORKING PRESSURE 175 PSI

FLANGES ARE 125 A.S.A.

\section{DIMENSIONS}

STANDARD SEAL 1510

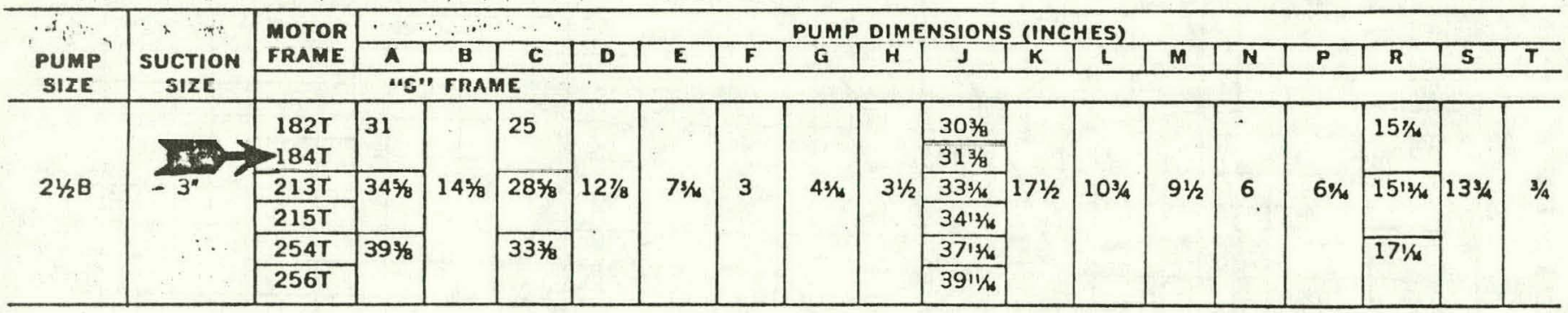

STUFFING BOX 1510-P, 1510-PF, 1510-S, 1510-D

\begin{tabular}{|c|c|c|c|c|c|c|c|c|c|c|c|c|c|c|c|c|c|c|c|}
\hline \multirow{3}{*}{$\begin{array}{l}\text { PUMP } \\
\text { SIZE }\end{array}$} & \multirow{3}{*}{$\begin{array}{c}\text { SUCTION } \\
\text { SIZE }\end{array}$} & \multirow{2}{*}{$\begin{array}{l}\text { MOTOR } \\
\text { FRAME }\end{array}$} & \multicolumn{17}{|c|}{ PUMP DIMENSIONS (INCHES) } \\
\hline & & & A & $\mathbf{B}$ & $\mathbf{C}$ & D & $\mathbf{E}$ & $\mathbf{F}$ & $\mathbf{G}$ & H & $J$ & $K$ & L & $M$ & $\mathbf{N}$ & $\mathbf{P}$ & $\mathbf{R}$ & $\mathbf{s}$ & $T$ \\
\hline & & \multicolumn{18}{|c|}{ "S" FRAME } \\
\hline \multirow{5}{*}{$21 / 2 B$} & \multirow{6}{*}{$\mathbf{3}^{\prime \prime}$} & $182 \mathrm{~T}$ & $34 \%$ & \multirow{4}{*}{$14 \% 8$} & \multirow[t]{2}{*}{285} & \multirow{4}{*}{$12 \%$} & \multirow{4}{*}{$7 \%$} & \multirow{4}{*}{3} & \multirow{4}{*}{$4 x_{0}$} & \multirow{6}{*}{$\begin{array}{l}31 / 2 \\
\cdots\end{array}$} & $3315 / 4$ & \multirow{4}{*}{$171 / 2$} & \multirow{4}{*}{$103 / 4$} & \multirow{6}{*}{$91 / 2$} & \multirow{6}{*}{6} & \multirow{6}{*}{$6 \%$} & \multirow[t]{2}{*}{$15 \%$} & \multirow{6}{*}{$13 \%$} & \multirow{4}{*}{$3 / 4$} \\
\hline & & $184 \mathrm{~T}$ & & & & & & & & & $3415 / 6$ & & & & & & & & \\
\hline & & $213 T$ & 39\% & & $337_{8}=$ & & & & & & $367 / 8$ & & & & & & $151 \mathrm{~K}$ & & \\
\hline & & $215 \mathrm{~T}$ & & & & & & & & & 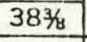 & & & & & & & & \\
\hline & & $254 \mathrm{~T}$ & $461 / 2$ & 16 & $361 / 2$ & 14 & 8 & 5 & 536 & & $411 / 2$ & \multirow[t]{2}{*}{$183 / 4$} & \multirow[t]{2}{*}{12} & & & & \multirow[t]{2}{*}{$181 / 6$} & & \multirow[t]{2}{*}{$7 / 8$} \\
\hline$\therefore$ & & $256 \mathrm{~T}$ & & , & & & & & : & & $431 / 4$ & & & & & & & & \\
\hline
\end{tabular}

BELL \& GOSSETT MORTON GROVE, ILL. 60053 TTTT

Fluid Handling Division, International Telephone and Telegraph Corporation 


\section{PERFORMANCE CURVES}

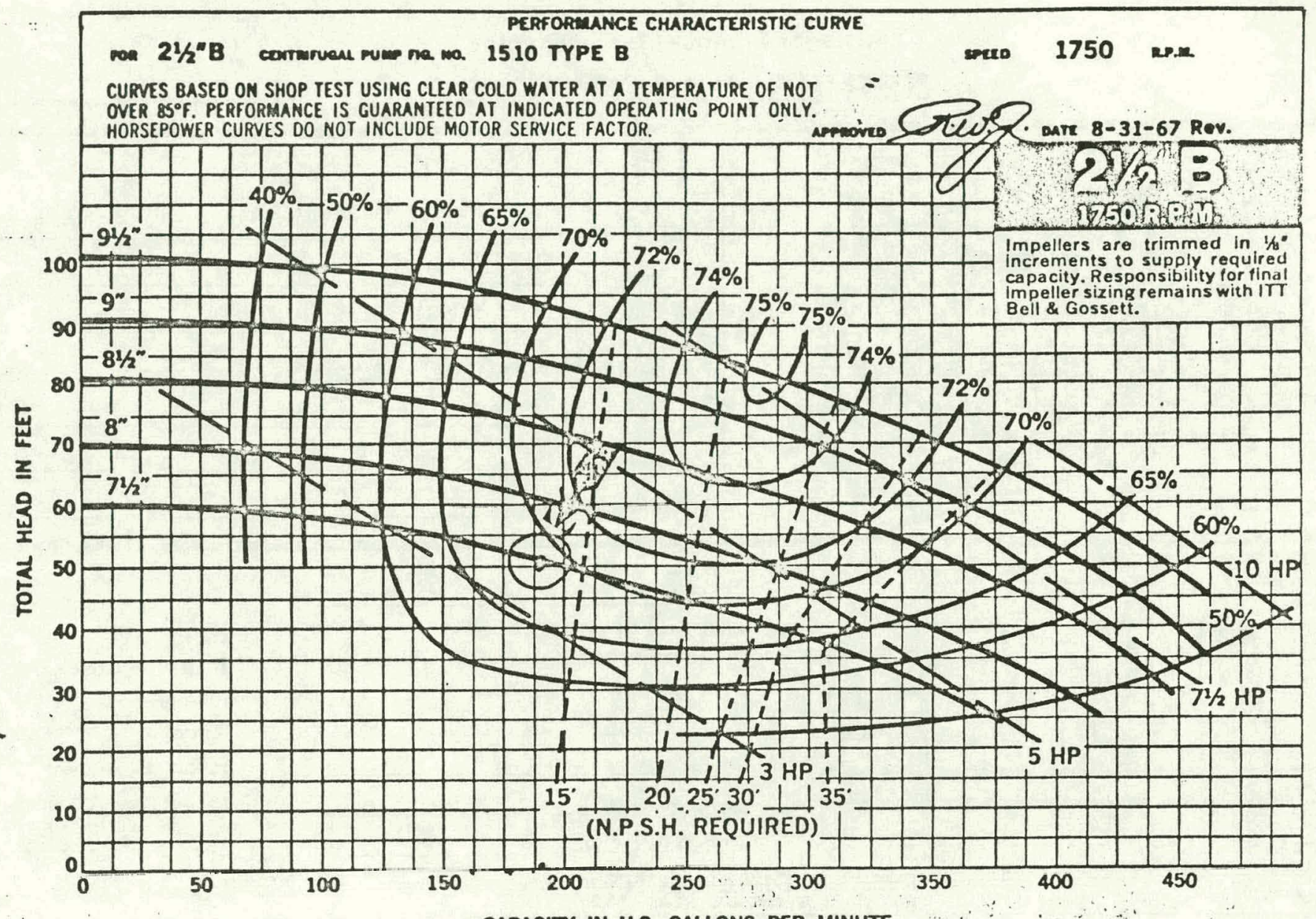

CAPACITY IN U.S. GALLONS PER MINUTE

PERFORIANACE CMARACTERISTIC CURVE

21/2"B conrarueal mum na wa. 1510 TYPE B

HORSEPOWER CURVES DO NOT INCLUDE MOTOR SERVICE FACTOR.

arroive $8-31-67$ Rev. 


\section{Centrifugal Pumps - Base Mounted SERIES 1510 TYPE B}
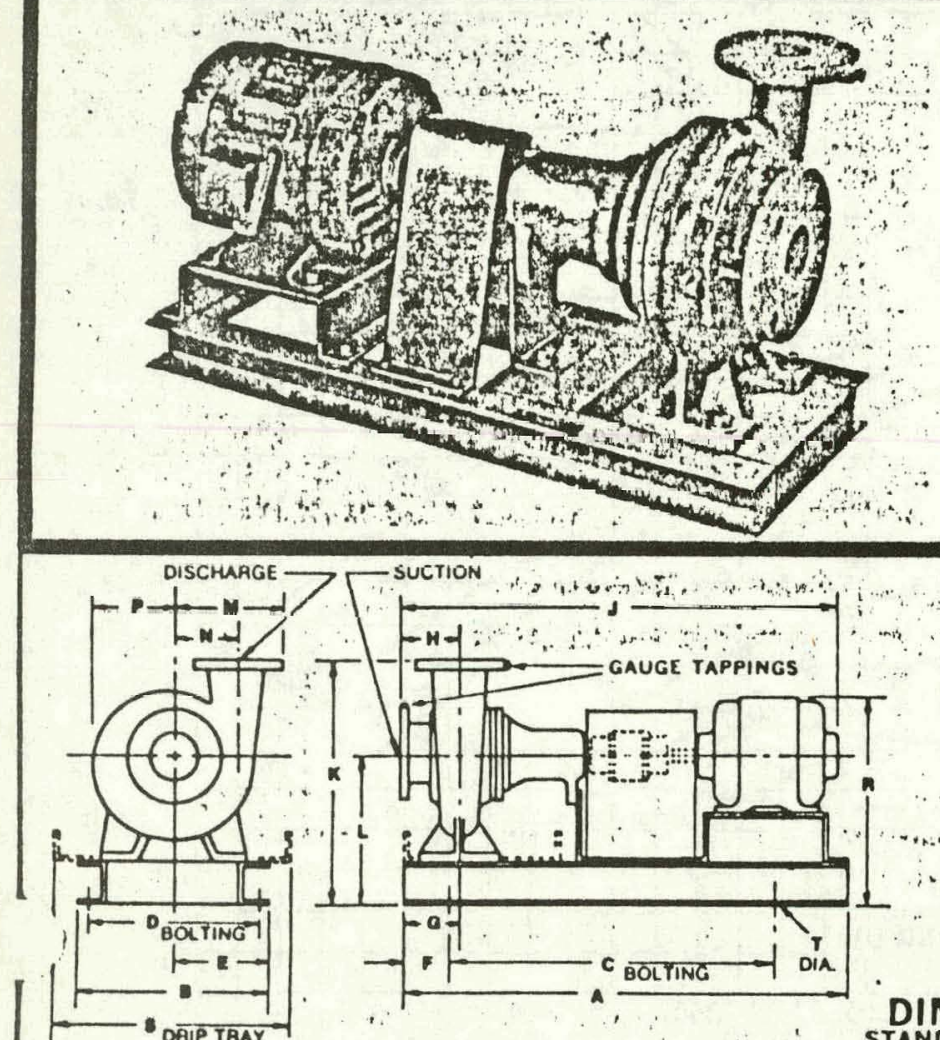

\section{3 \\ SPECIFICATIONS}

MATERIALS OF CONSTRUCTION:

酋 BRONZE FITTED $\square$ A 5 IRON $\square$ ALL BRONZE 1510 (Standard Seal)

ELECTRICAL DATA: 5 HP

240

volts 60

Cr. 3 PH.

$\square$ 1510.PF

MOTOR ENCL OPDP

(Packing-Flushed)

SPEC. CONSTR.

APPROXIMATE WEIGHT

260

$\square$ 1510-s (Single Sea1)

IMENSIONS

LBS. FLANGES ARE 125 A.S.A. STANDARD SEAL 1510

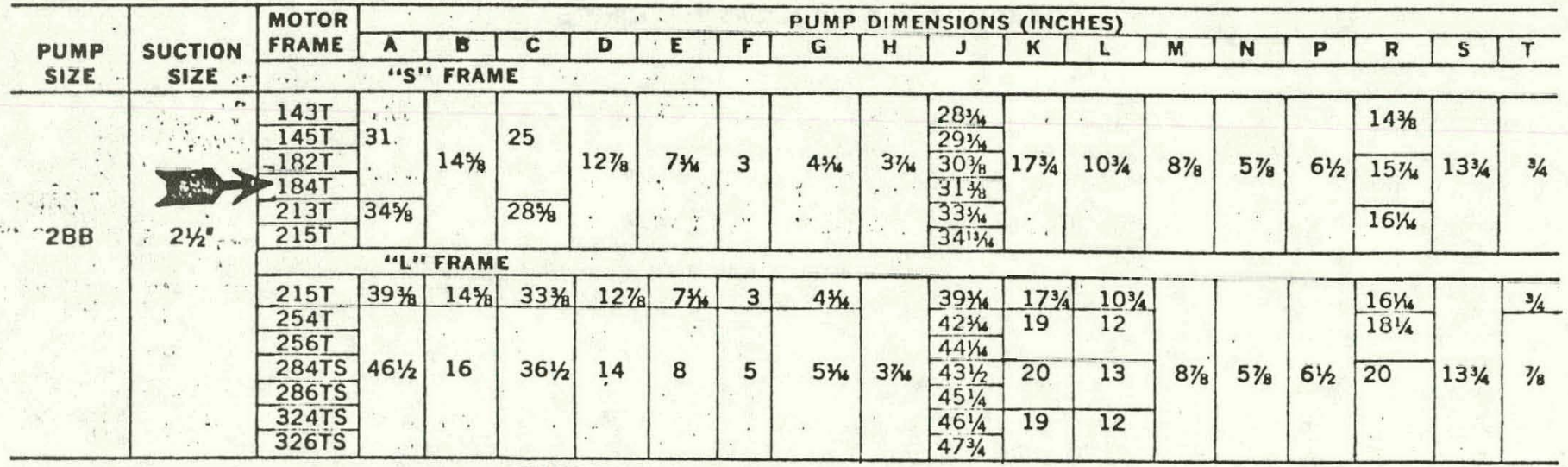

STUFFING BOX 1510-P, 1510-PF, 1510-S, 1510-D

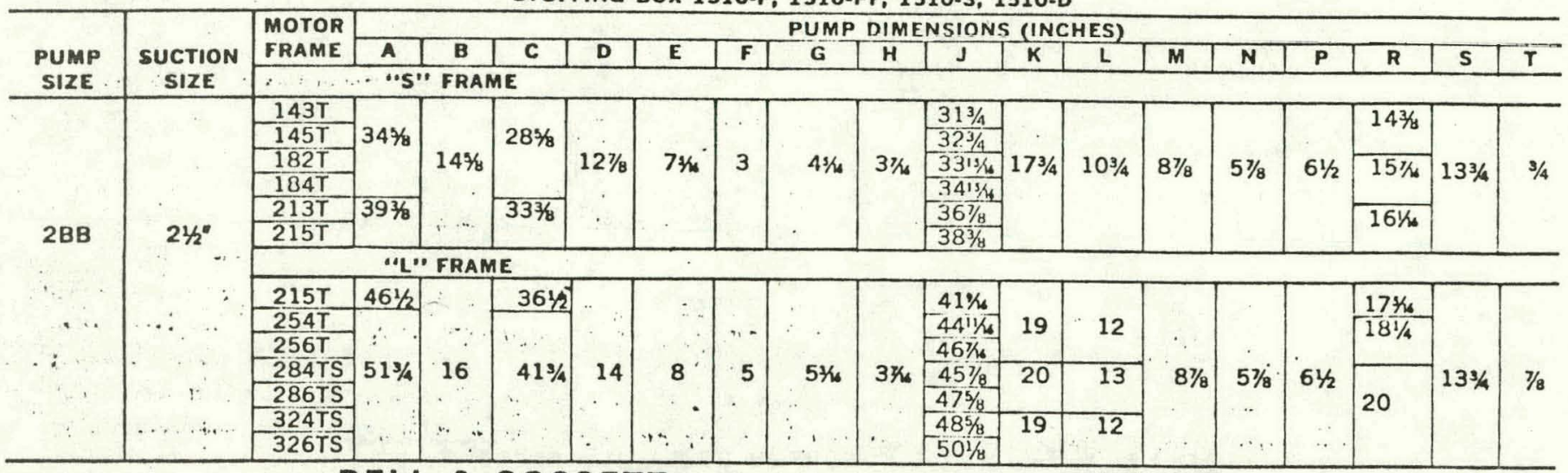

BELL \& GOSSETT MORTON GROVE. ILL. 60053 TTITI

Fluid Handling Division, International Telephone and Telegraph Corporation 


\section{PERFORMANCE CURVES}

\section{PERFORMANCE CHARACTERISTIC CURVE}

ron 2"BB centraruent pump ne. nо. 1510

Spted 1750 R.P.M.

CURVES BASED ON SHOP TEST USING CLEAR COLD WATER AT A TEMPERATURE OF NOT

OVER $85^{\circ}$ F. PERFORMANCE IS GUARANTEED AT INDICATED OPERATING POINT ONLY.

HORSEPOWER CURVES DO NOT INCLUDE MOTOR SERVICE FACTOR.

appmoveo \&S. L. D. Dare 8-25-67

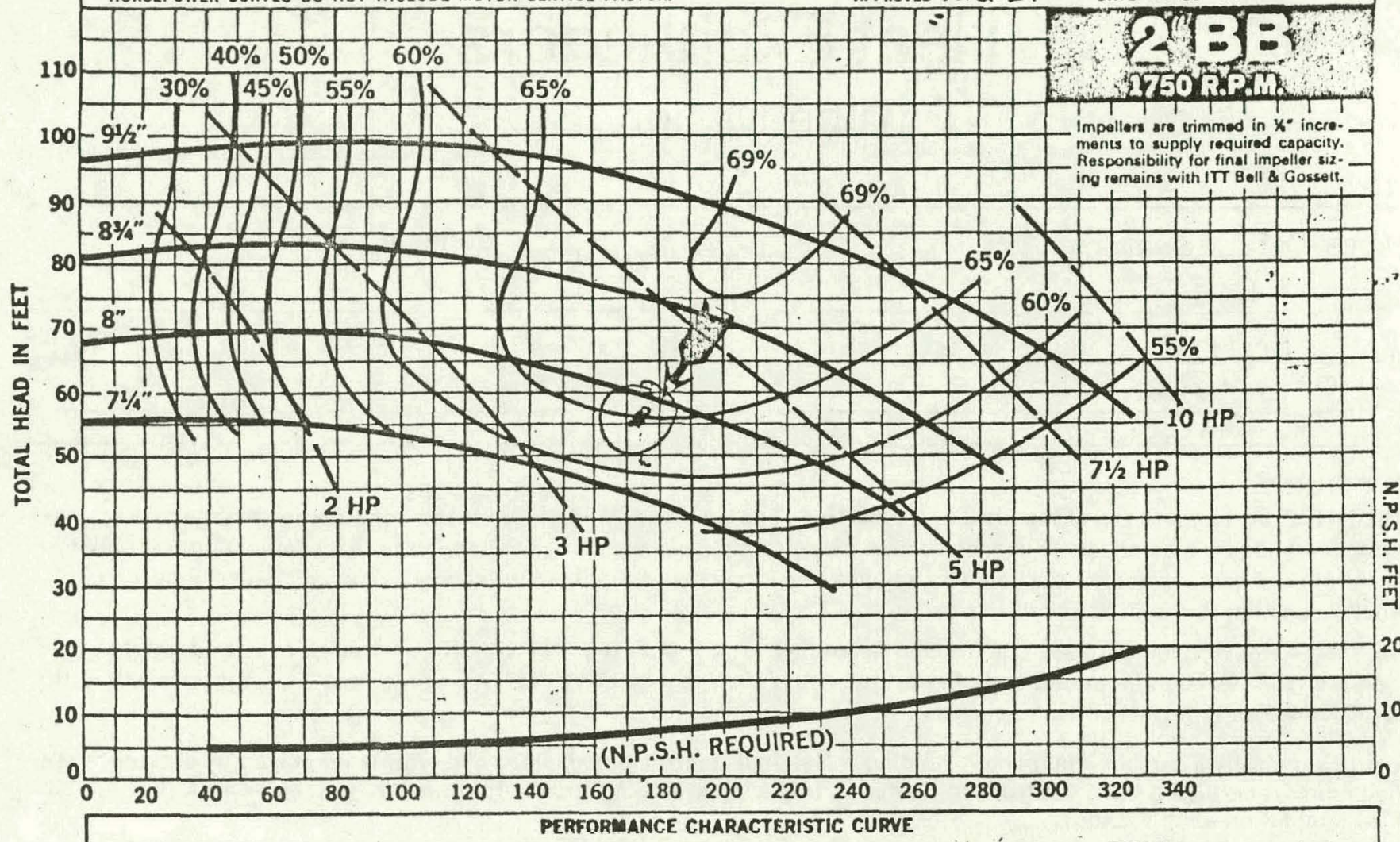

von $2^{\prime \prime B B}$ centwrueal mum na. wa. 1510

gezeo 3500 ep.m.

CURVES BASED ON SHOP TEST USING CLEAR COLD WATER AT A TEMPERATURE OF NOT

OVER 85०F. PERFORMANCE IS GUARANTEED AT INDICATED OPERATING POINT ONLY.

HORSEPOWER CURVES DO NOT INCLUDE MOTOR SERVICE FACTOR.

H.L.F. Dare $8-29-67$

$30 \%-45 \%-55 \%$

$440-\quad$\begin{tabular}{c|c|c|c|c|}
\hline & $40 \%$ & $50 \%$ & $60 \%$
\end{tabular}

440

$000-91 / 2^{\prime \prime}$ . 11

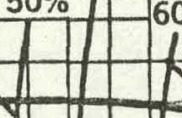

appoved

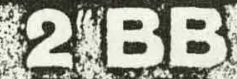

$65 \%$
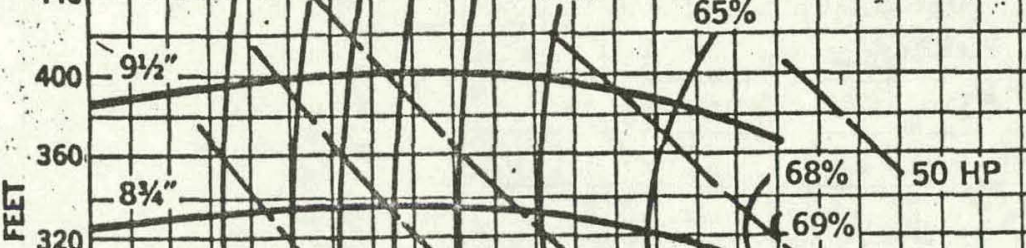

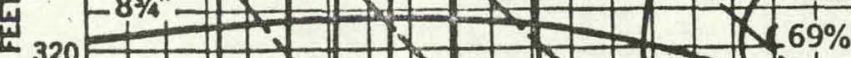

z

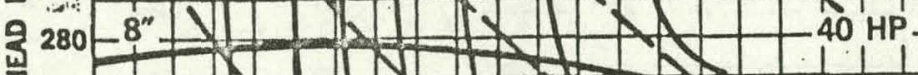

모 DNDO

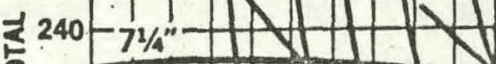

은

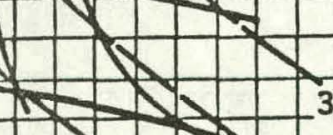

$30 \mathrm{HP}$

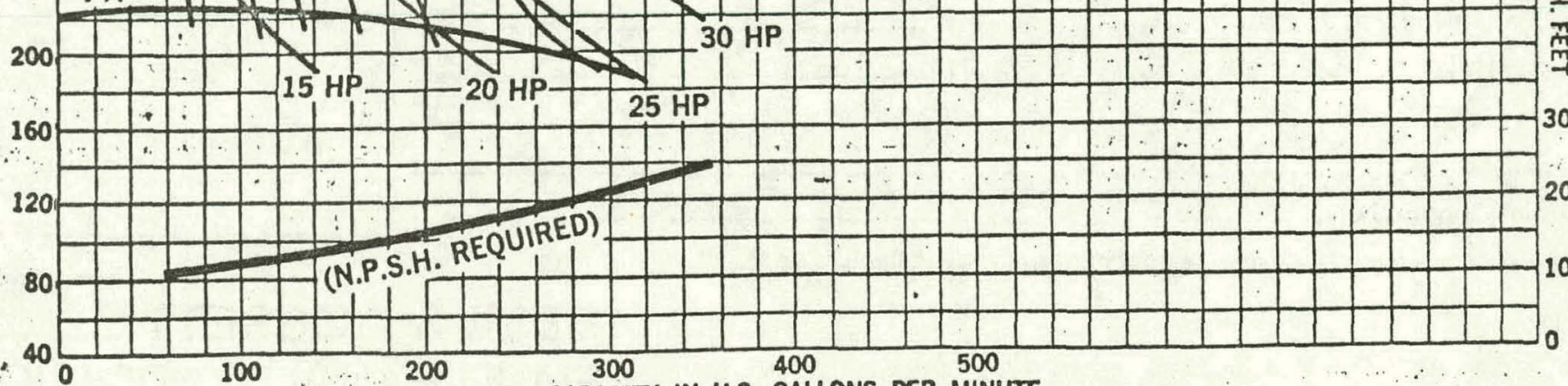

100 


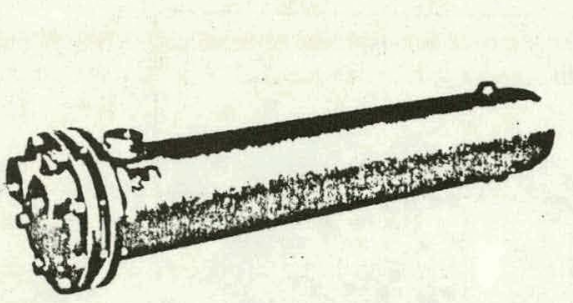

\begin{tabular}{|c|c|}
\hline лов Coca-Cola Jackson, TN & B \& G Representative Johnson \& Scott \\
\hline UNIT TAG NO. $\mathrm{HX}-1$ & ORDER NO. 1252 \\
\hline ENGINEER Griffith C. Burr & suвміттер ву Gene Mankowski \\
\hline Contractor Morgan \& Turner & APYHUVEU BY_ DATE \\
\hline
\end{tabular}

\section{DESCRIPTION}

B\&G "WU" Heat Exchangers are of the shell and tube type. The tube bundle is of " $U$ " bend construction with tube ends expanded, into a stationary tube sheet. This construction permits ample expansion or contraction for wide temperature variations. A fluid entering the tubes is heated or cooled by a fluid being circulated through a baffled shell. The unit is designed primarily for pumped circulation through the shell.

Standard "WU" Heat Exchangers are constructed according to A.S.M.E. requirements for pressures and temperature noted in table on the rear. A Manufacturers' Data Report for Pressure Vessels, Form No. U-1 as required by the provisions of the A.S.M.E. Code Rules is furnished with each unit.

This form is signed by a qualified inspector, holding a National Board Commission, and who is employed by an authorized inspection agency, certifying that construction conforms to the latest A.S.M.E. code for pressure vessels. The A.S.M.E. "U" symbol is stamped on each vessel.

\section{RECOMMENDED "WU" HEAT EXCHANGER}

MODEL NO. 109-45

APPROVALS

HEATING SURFACE (SQ. FT.) 125

1. Fluid Circulated.

OPERATING DATA

TUBE SIDE

Water

SHELL SIDE

2. Total Flow" ("Expressed in GPM.GPH, or lbs./hr.) 63

3. Temperature In/Out.

$160 \quad 140$ Watcr

4. Transfer BTU/hr. 622,000

5. Pressure Drop (Maximum) 2.5FT

$\frac{\frac{63}{120 / 140}}{\frac{622,000}{1.5 \mathrm{FT}}}$

6. Fouling Factor or Percentage of Additional Surface. 001 Note: Following applies only for fluids other than water.

7. Specific Gravity.

8. Specific Heat

9. Latent Heat.

10. Viscosity"*

11. Thermal Conductivity

- Expressed in Proper Units and Temperature such as centipolses (a. ${ }^{\circ} \mathrm{F}$. 
2 PASS HEAD

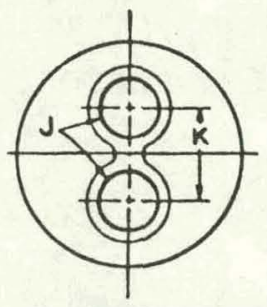

4 PASS HEAD

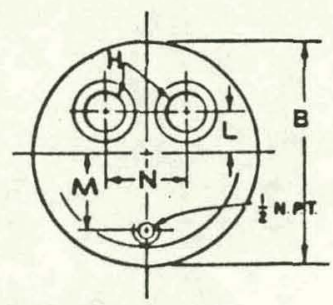

Optional Cast Iron

150 PSI OESIGN PRESSURE HEADS (Flanged Connections)

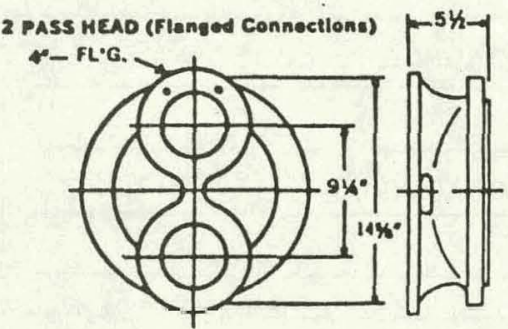

6 PASS - HEAO

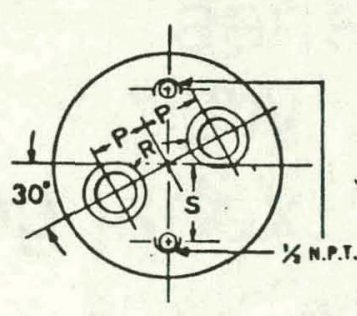

$\square U$

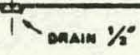

Flange connections for field piping drilled and laced per 150 ANSI standards.

Room for removal of tube bundle, equal to or ereater than " $A$ ". should be provided.

Cast iron or bolted steel legs can be supplied when specified.

\section{DIMENSIONS}

\begin{tabular}{|c|c|c|c|c|c|c|c|c|c|}
\hline & & & \multicolumn{7}{|c|}{ DIMENSIONS } \\
\hline & & & \multicolumn{2}{|c|}{2 PASS } & \multicolumn{4}{|c|}{4 PASS } & \\
\hline$\stackrel{2}{\text { PASS }}$ & PASS & PASS & 1 & K & H & L & m & N & $\mathbf{p}$ \\
\hline WU104-25 & WU104-45 & WU104-65 & 4 NPT & $5 \%$ & $3 \mathrm{NPT}$ & $23 \%$ & $4 \%$ & $43 / 6$ & $313 / 6$ \\
\hline WU105-25 & WU105-45 & WU105-64 & 4 NPT & $5 \%$ & $3 \mathrm{NPT}$ & $23 / 8$ & $4 \frac{1}{8}$ & $43 / 4$ & $313 / 6$ \\
\hline WU106-25 & WU106-45 & WU106-65 & 4 NPT & $5 \%$ & $3 \mathrm{NPT}$ & $23 / 8$ & $4 \frac{1}{8}$ & $43 / 4$ & $313 / 6$ \\
\hline WU107-25 & WU107-45 & Wu107-65 & 4 NPT & $5 \%$ & 3 NPT & $23 / 8$ & $4 \%$ & $43 / 4$ & $313 / 6$ \\
\hline WU108-25 & MU108-45 & WU108-65 & 4 NPT & $5 \%$ & 3 NPT & $23 / 2$ & $41 / 8$ & $43 / 4$ & $312 / 6$ \\
\hline WU109-25 & WU109-45 & WU109-65 & $4 \mathrm{NPT}$ & $5 \%$ & $3 \mathrm{NPT}$ & $23 / 8$ & $4 \%$ & $43 / 4$ & $313 / 6$ \\
\hline WU1010-25 & WU1010-45 & WU1010-65 & $4 \mathrm{NPT}$ & $5 \%$ & 3 NPT & $23 / 8$ & $4 \%$ & $43 / 4$ & 31318 \\
\hline
\end{tabular}

\begin{tabular}{|c|c|c|c|c|c|}
\hline \multicolumn{4}{|c|}{ DESIGN PRESSURES* } & \multirow{2}{*}{\multicolumn{2}{|c|}{$\begin{array}{l}\text { DESIGN TEMPERATURES } \\
\text { TUBE \& SHELL SIDE }\end{array}$}} \\
\hline \multicolumn{2}{|c|}{ TUBE SIDE } & \multicolumn{2}{|c|}{ SHELL SIDE } & & \\
\hline DESIGN & TEST & DESIGN & . TEST & CAST IRON & BRASS \\
\hline \multicolumn{6}{|c|}{4 \& 6 Pass } \\
\hline $150 \mathrm{psi}$ & 300 psi & $150 \mathrm{psi}$ & $300 \mathrm{psi}$ & $375 \mathrm{~F}$ & $300 \mathrm{~F}$ \\
\hline \multicolumn{6}{|c|}{2 Pass } \\
\hline 125 psi & $250 \mathrm{psi}$ & 150 psi & $300 \mathrm{psi}$ & $375 \mathrm{~F}$ & $300 \mathrm{~F}$ \\
\hline \multicolumn{6}{|c|}{2 Pass Head (Flanged Connections) Cast Iron only } \\
\hline $150 \mathrm{psi}$ & 300 psi & $150 \mathrm{psi}$ & $300 \mathrm{psi}$ & $375 \mathrm{~F}$ & - \\
\hline
\end{tabular}

- For desion pressures and temperatures hlgher than shown, consult B \& G Representative for epeciflcations and dimensions.

Caution:

A properly sized relief valve must be installed on the heated water side to protect heat exchangers from possible damage due to volumetric expansion.

PRINTED IN U.S.A. 8.76

MATERIALS

\begin{tabular}{l|l|l}
\hline \multicolumn{1}{c|}{ PART } & $\begin{array}{c}\text { STANDARD } \\
\text { CAST IRON UNIT }\end{array}$ & \multicolumn{1}{c}{ BRASS UNIT } \\
\hline & 2,4 \& 6 Pass & \multicolumn{1}{|c}{2 \& 4 Pass } \\
\hline Shell & Steel & Steel. \\
Head & Cast Iron & Cast Brass \\
Tubes 3/4" O.D. & Copper & Copper \\
Tube Sheet & Steel & Rolled Naval Brass \\
Baffles & Steel & Steel \\
Nuts \& Bolts & Steel & Steel \\
\hline
\end{tabular}

BELL \& GOSSETT

O200 N AUSTIN AVE. - MORTON GROVE. ILL 6005J INTERNATIONAL TELEPHONE AND TELEGRAPH CORPORATIO 


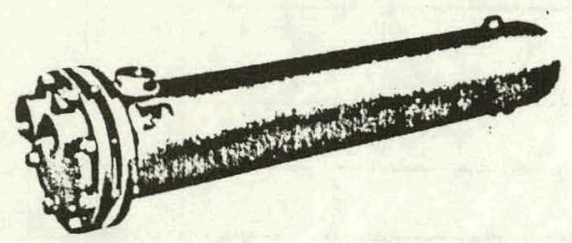

\begin{tabular}{|c|c|}
\hline Coca-Cola Jackson, TN & Johnson \& Scott \\
\hline UNIT TAG NO. HX-2 & ORDER NO. 1252 \\
\hline ENGINEER Griffith C. Burr & Gene Mankowski \\
\hline CONTAACTOR Morgan \& Turner & APPROVED BY_ DATE \\
\hline
\end{tabular}

\section{DESCRIPTION}

B\&G "WU" Heat Exchangers are of the shell and tube type. The tube bundle is of " $U$ " bend construction with tube ends expanded into a stationary tube sheet. This construction permits ample expansion or contraction for wlde temperaluie variatiuis. A fluid entering the tubes is heated or cooled by a fluid being circulated through a baffled shell. The unit is designed primarily for pumped circulation through the shell.

Standard "WU" Heat Exchangers are constructed according to A.S.M.E. requirements for pressures and temperature noted in table on the rear. A Manufacturers' Data Report for Pressure Vessels, Form No. U-1 as required by the provisions of the A.S.M.E. Code Rules is furnished with each unit.

This form is signed by a qualified inspector, holding a National Board Commission, and who is employed by an authorized inspection agency, certifying that construction conforms to the latest A.S.M.E. code for pressure vessels. The A.S.M.E. "U" symbol is stamped on each vessel.

RECOMMENDED "WU" HEAT EXCHANGER .

MODEL NO. 128-46

HEATING SURFACE (SQ. FT.) 160

APPROVALS

\section{OPERATING DATA}

TUBE SIDE SHELL SIDE

Water Water

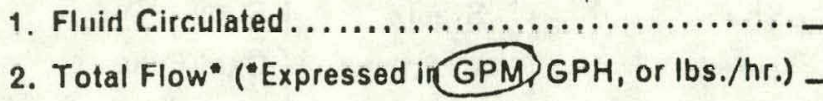

3. Temperature In/Out.....................

4. Transfer BTU/hr.

90

5. Pressure Drop (Maximum).

$190 / 179 \frac{160 / 178}{567,000}$

567,000

4.1

6. Fouling Factor or Percentage of Additional Surface

.001

567,000

Note: Following applies only for fluids other than water.

7. Specific Gravity

8. Specific Heat.

9. Latent Heat

10. Viscosity"*

11. Thermal Conductivity

- Expressed in Proper Units and Temperature such as centipoises @ $\bullet$ F. 
2 PASS MEAO

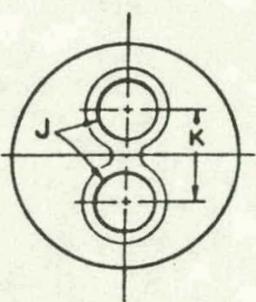

Optional Cast Iron

150 PSI DESIGN PRESSURE MEADS (FIanged COnnections)

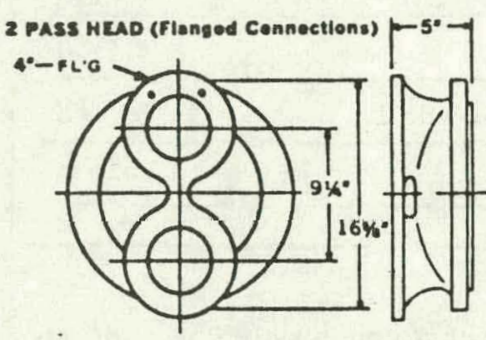

6 PASS HEAD

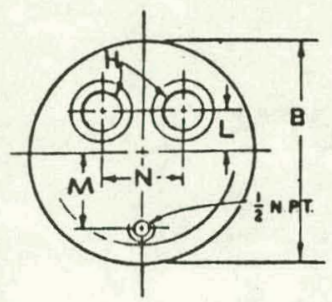

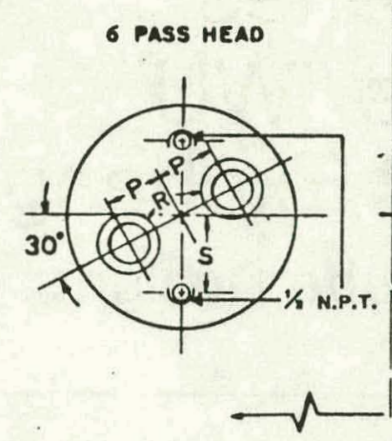

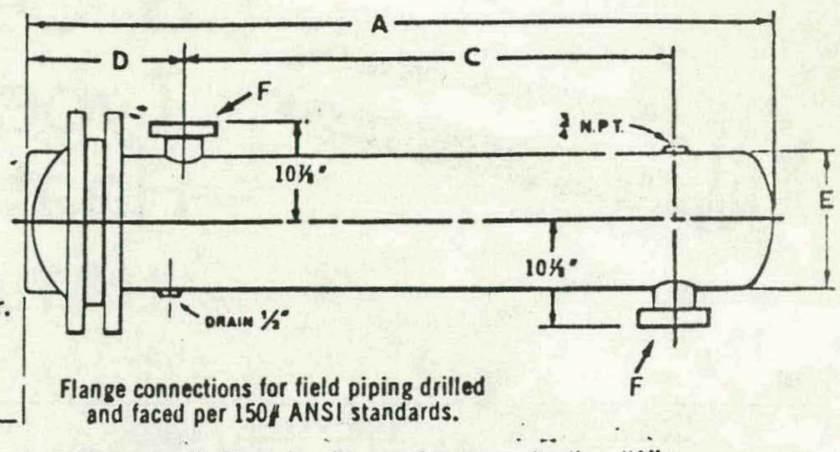

Room for removal of tube bundle, equal to or greater than " $A$ ". should be provided.

Cast iron or bolted steel legs can be supplied when specified.

\section{DIMENSIONS}

Complete sales number consists of example: Wu126.26

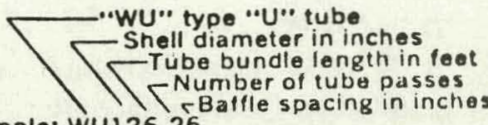

\begin{tabular}{|c|c|c|c|c|c|c|c|c|c|c|c|c|c|c|c|c|c|c|c|c|c|}
\hline \multicolumn{3}{|c|}{ DIMENSIONS } & \multicolumn{19}{|c|}{ Complete sales number consists of example: WU126.26 } \\
\hline & & & \multicolumn{15}{|c|}{ DIMENSIONS IN INCHES } & \multirow{2}{*}{\multicolumn{3}{|c|}{ 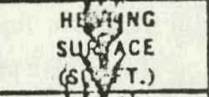 }} & \multirow{3}{*}{$\begin{array}{l}\text { APPROX. } \\
\text { SHIPPING } \\
\text { WT. (LBS.) }\end{array}$} \\
\hline & & & \multicolumn{2}{|c|}{2 PASS } & \multicolumn{4}{|c|}{4 PASS } & \multicolumn{3}{|c|}{6 PASS } & \multicolumn{6}{|c|}{ 2, 4 AND 6 PASS } & & & & \\
\hline$\stackrel{2}{\text { PASS }}$ & $\begin{array}{l}\text { PASS } \\
\text { PAs }\end{array}$ & PASS & 1 & K & H & $\mathbf{L}$ & $m$ & N & $P$ & R & s & A & 8 & c & D & E & $\begin{array}{c}\mathrm{FLG} \\
\mathbf{F}\end{array}$ & $\begin{array}{c}2 \\
\text { Pass }\end{array}$ & $\begin{array}{l} \\
p \\
\text { pass }\end{array}$ & \begin{tabular}{c|}
6 \\
Pass \\
\end{tabular} & \\
\hline WU124-26 & WU124-46 & WU124-66 & 4 NPT & $73 / 4$ & 4 NPT & $2 \%$ & $5 \frac{1}{8}$ & $5 \% / 8$ & $41 / 2$ & 3 NPT & $513 / 6$ & $561 / 2$ & $16 \%$ & $37 \%$ & $101 / 4$ & $12 \%$ & 5 & 83 & 78 & 68 & 456 \\
\hline WU125-26 & WU125-46 & WU125-66 & $4 \mathrm{NPT}$ & $73 / 4$ & $4 \mathrm{NPT}$ & $25 / 8$ & $51 / 8$ & $5 \%$ & $41 / 2$ & 3 NPT & $513 / 6$ & $681 / 2$ & $16 \%$ & $491 / 4$ & $10 \%$ & $123 / 4$ & 5 & 104 & 98 & 85 & 525 \\
\hline WU126.26 & WU126-46 & WU126-66 & $4 \mathrm{NPT}$ & $73 / 4$ & $4 \mathrm{NPT}$ & $25 / 8$ & $5 \%$ & $5 \%$ & $41 / 2$ & 3 NPT & $513 / 4$ & $801 / 2$ & $16 \%$ & $611 / 4$ & $101 / 4$ & $123 / 4$ & 5 & 126 & 119 & 103 & 594 \\
\hline WU127-26 & WU127-46 & WU127.66 & $4 \mathrm{NPT}$ & $73 / 4$ & 4 NPT & $25 / 8$ & $5 \%$ & $5 \%$ & $41 / 2$ & 3 NPT & $512 / 16$ & $921 / 2$ & $16 \%$ & $731 / 4$ & $101 / 4$ & $123 / 4$ & 5 & 148 & 139 & 121 & 663 \\
\hline स्रेण128.26 & WU128-46 & WU128.66 & $4 \mathrm{NPT}$ & $73 / 4$ & $4 N P T$ & $25 / 1$ & $5 \%$ & $5 \%$ & $41 / 2$ & 3 NPT & $513 / 4$ & $1041 / 2$ & $165 / 8$ & $851 / 4$ & $10 \%$ & $123 / 4$ & 5 & 169 & 160 & 139 & 732 \\
\hline Wu129-26 & WU129.46 & WU129.66 & 4 NPT & $7 \%$ & 4 NPT & $2 \%$ & $51 / 8$ & $5 \%$ & $41 / 2$ & 3 NPT & $513 / 16$ & $1161 / 2$ & $16 \%$ & $971 / 4$ & $101 / 4$ & $123 / 4$ & 5 & $19 !$ & 180 & 156 & 801 \\
\hline
\end{tabular}

\section{DESIGN PRESSURES-A.S.M.E. CONSTRUCTION CAST IRON \& BRASS UNITS}

\begin{tabular}{|c|c|c|c|c|c|}
\hline \multicolumn{4}{|c|}{ DESIGN PRESSURES * } & \multirow{2}{*}{\multicolumn{2}{|c|}{$\begin{array}{l}\text { DESIGN TEMPERATURES } \\
\text { TUBE \& SHELL SIDE }\end{array}$}} \\
\hline \multicolumn{2}{|c|}{ TUBE SIDE } & \multicolumn{2}{|c|}{ SHELL.SIDE } & & \\
\hline DESIGN & TEST & DESIGN & TEST & CAST IRON & BRASS \\
\hline \multicolumn{6}{|c|}{6 Pass } \\
\hline $150 \mathrm{psi}$ & 300 psi & $150 \mathrm{psi}$ & 300 psi & $375 \mathrm{~F}$ & $-\ldots$ \\
\hline \multicolumn{6}{|c|}{$2 \& 4$ Pass } \\
\hline 125 psi & $250 \mathrm{psi}$ & $150 \mathrm{psi}$ & 300 psi & $375 \mathrm{~F}$ & $300 \mathrm{~F}$ \\
\hline \multicolumn{6}{|c|}{2 Pass Head (Flanged Connections) Cast Iron only } \\
\hline 150 psi & 300 psi & $150 \mathrm{psi}$ & 300 psi & $375 \mathrm{~F}$ & - \\
\hline
\end{tabular}

- For deslgn pressures and temperatures higher than shown.

coneult B \& G Representative for specifications and dimensions.

Caution:

A properly sized relief valve must be installed on the heated water side to protect heat exchangers from possible damage due to volumetric expansion.

$$
\text { ? }
$$

PRINTED IN U.S.A. 8.76

\section{MATERIALS}

\begin{tabular}{l|l|l}
\hline \multicolumn{1}{c|}{ PART } & $\begin{array}{c}\text { STANDARD } \\
\text { CAST IRON UNIT }\end{array}$ & \multicolumn{1}{c}{ BRASS UNIT } \\
\hline & $2,4 \& 6$ Pass & \multicolumn{1}{|c}{2 \& 4 Pass } \\
\hline Shell & Steel & Steel \\
Head & Cast Iron & Cast Brass \\
Tubes 3/4" O.D. & Copper & Copper \\
Tube Sheet & Steel & Rolled Naval Brass \\
Baffles & Steel & Steel \\
Nuts \& Bolts & Steel & Steel \\
\hline
\end{tabular}

BELL \& GOSSETT

$8200 \mathrm{~N}$ AUSTIN AVE. MORTON GROVE. ILL 60053 INTEANATIONAL TELEPHONE AND TELEGRAPH CORPORATION 


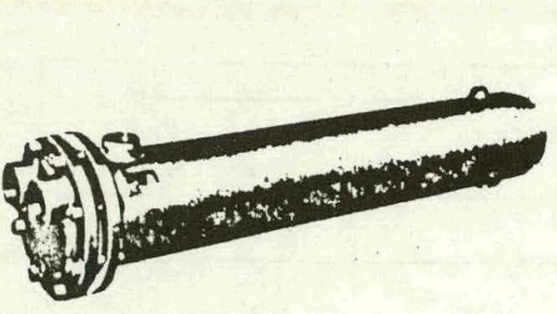

\section{8" Series}

\begin{tabular}{|c|c|}
\hline Coca-Cola Jackson, TN & Johnson \& Scott \\
\hline UNIT TAG NO. HX-3 & ORDER NO. $\quad 1252$ \\
\hline ENGINEER Griffith C. Burr & Gene Mankowski \\
\hline Contracton Morgan \& Turner & APPROVED BY \\
\hline
\end{tabular}

\section{DESCRIPTION}

B\&G "WU" Heat Exchangers are of the shell and tube type. The tube bundle is of "U" bend construction with tube ends expanded into a stationary tube sheet. This construction permits ample expansion or contraction for wide temperature variations. A fluid entering the tubes is heated or cooled by fluid being circulated through a baffled shell. The unit is designed primarily for pumped circulation through the shell.

Standard "WU" Heat Exchangers are constructed according to A.S.M.E. requirements for pressures and temperature noted in table on the rear. A Manufacturers' Data Report for Pressure Vessels, Form No. U-1 as required by the provisions of the A.S.M.E. Code Rules is furnished with each unit.

This form is signed by a qualified inspector, holding a National Board Commission, and who is employed by an authorized inspection agency, certifying that construction conforms to the latest A.S.M.E. code for pressure vessels. The A.S.M.E. "U" symbol is stamped on each vessel.

RECOMMENDED "WU" HEAT EXCHANGER MODEL NO. $89-43$

HEATING SURFACE (SQ. FT.) 75

1. Fluid Circulated.

OPERATING DATA TUBE SIDE SHELL SIDE

2. Total Flow" ("Expressed in GPM GPH, or lbs./hr.)

3. Temperature In/Out Water Water

4. Transfer BTU/hr.

$66-\frac{12}{160}$

5. Pressure Drop (Maximum)

349,000

$160 / 177$

6. Fouling Factor or Percentage of Additional Surface ... 001

Note: Following applies only for fluids other than watẹr.

7. Specific Gravity

8. Specific Heat.

9. Latent Heat

10. Viscosity

11. Thermal Conductivity

- Expressed in Proper Units and Temperature such as centipoises @ ${ }^{\bullet} \mathrm{F}$. 

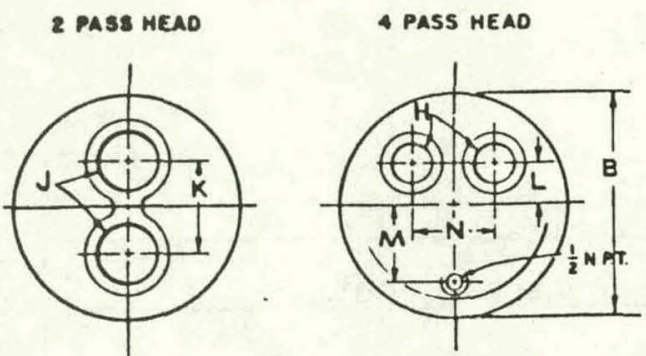

Cast iron or bolted steel legs can be supplied when specified.
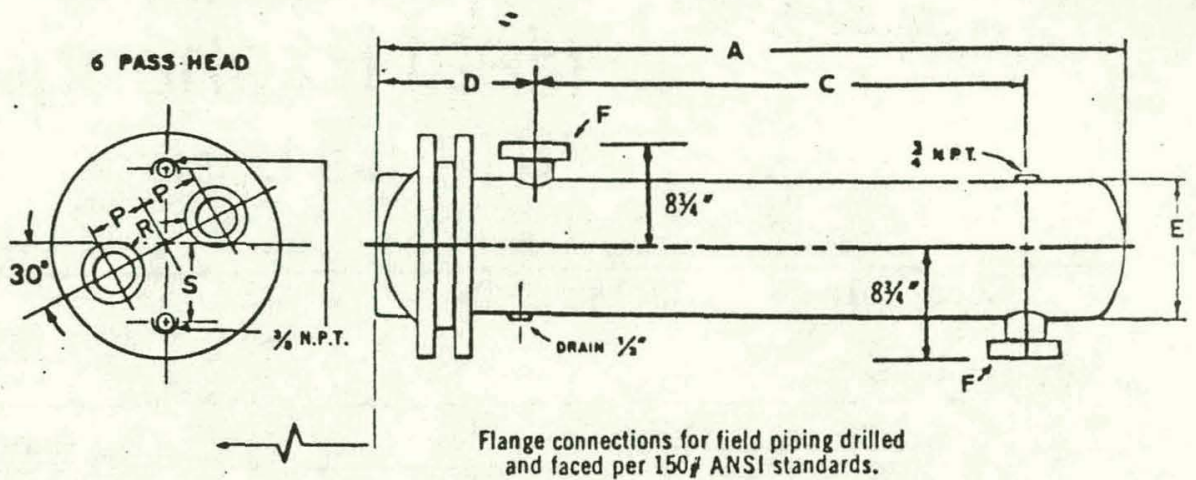

Flange connections for field piping drilled and faced per 150, ANSI standards.

Room for removal of tube bundle, equal to or greater than "A". should be provided.

\section{DIMENSIONS}

\begin{tabular}{|c|c|c|c|c|c|c|c|c|c|}
\hline \multirow{2}{*}{\multicolumn{3}{|c|}{ UNIT }} & \multicolumn{7}{|c|}{ DIMENSION } \\
\hline & & & \multicolumn{2}{|c|}{2 PASS } & \multicolumn{4}{|c|}{4 PASS } & \\
\hline $\begin{array}{c}2 \\
\text { PASS }\end{array}$ & $\begin{array}{l}\text { PASS } \\
\text { PAS }\end{array}$ & $\begin{array}{c}6 \\
\text { PASS }\end{array}$ & 1 & K & H & L & $M$ & N & $\mathbf{P}$ \\
\hline WU84-24 & WU84-44 & WU84-64 & 3 NPT & 5 & 2 NPT & 2 & $31 / 2$ & 4 & 3 \\
\hline WU85-24 & WU85-44 & WU85-64 & 3 NPT & 5 & $2 \mathrm{NPT}$ & 2 & $31 / 2$ & 4 & 3 \\
\hline WU86-24 & WU86-44 & WU86-64 & $3 \mathrm{NPT}$ & 5 & $2 N P T$ & 2 & $31 / 2$ & 4 & 3 \\
\hline WU $87-24$ & WU87.44 & WU87.64 & 3 NPT & 5 & $2 \mathrm{NPI}$ & 2 & $31 / 2$ & 4 & 3 \\
\hline WU88.24 & WU 88.44 & WU88-64 & $3 \mathrm{NPT}$ & 5 & $2 \mathrm{NPT}$ & 2 & $31 / 2$ & 4 & 3 \\
\hline WU89-24 & WU89.44 & WU89-64 & 3 NPT & 5 & 2 NPT & 2 & $31 / 2$ & 4 & 3 \\
\hline DE & IGN PI & $\begin{array}{l}\text { ESSUR } \\
\text { AST IR }\end{array}$ & $\begin{array}{l}S-A \\
N \&\end{array}$ & M. & $\begin{array}{l}\text { E. CO } \\
\text { SS UA }\end{array}$ & $\begin{array}{l}\text { NS } \\
\text { IIT }\end{array}$ & & 4 & DN \\
\hline
\end{tabular}

\begin{tabular}{|c|c|c|c|c|c|}
\hline \multicolumn{4}{|c|}{ DESIGN PRESSURES * } & \multirow{2}{*}{\multicolumn{2}{|c|}{$\begin{array}{l}\text { DESIGN TEMPERATURES } \\
\text { TUBE \& SHELL SIDE }\end{array}$}} \\
\hline \multicolumn{2}{|c|}{ TUBE SIDE } & \multicolumn{2}{|c|}{ SHELL SIDE } & & \\
\hline DESIGN & TEST & DESIGN & TEST & CAST IRON & BRASS \\
\hline 150 psi & 300 psi & 150 psi & $300 \mathrm{psi}$ & $375 \mathrm{~F}$ & $300 \mathrm{~F}$ \\
\hline
\end{tabular}

- For design pressures and temperatures higher than shown, consult B \& G Representative for specifications and dimensions.

Caution:

A properly sized relief valve must be installed on the heated water side to protect heat exchangers from possible damage due to volumetric expansion.

\section{MATERIALS}

\begin{tabular}{l|l|l}
\hline \multicolumn{1}{c|}{ PART } & $\begin{array}{c}\text { STANDARD } \\
\text { CAST IRON UNIT }\end{array}$ & \multicolumn{1}{c}{ BRASS UNIT } \\
\hline & 2,4 \& 6 Pass & \multicolumn{1}{c}{ 2 \& 4 Pass } \\
\hline Shell. & Steel & Steel \\
Head & Cast Iron & Cast Brass \\
Tubes 3/4" O.D. & Copper & Copper \\
Tube Sheet & Steel & Rolled Naval Brass \\
Baffles & Steel & Steel \\
Nuts \& Bolts & Steel & Steel \\
\hline
\end{tabular}




\begin{tabular}{|c|c|}
\hline $\begin{array}{lcc}\text { Joca-Cola } & \text { Jackson, TN } \\
& H X-4 & \end{array}$ & B \& G Representative Johnson \& Scott \\
\hline Griffith C. Burr & SUBMITTED BY Gene Mankowski \\
\hline CONTAACTOR Morgan \& Turner & APPROVED BY \\
\hline
\end{tabular}

\section{DESCRIPTION}

B\&G "WU" Heat Exchangers are of the shell and tube type. The tube bundle is of " $U$ " bend construction with tube ends expanded into a stationary tube sheet. This construction permits ample expansion or contraction for wide temperature variations. A fluid entering the tubes is heated or cooled by a fluid being circulated through a baifled shell. The unit is designed primarily for pumped circulation through the shell.

Standard "WU" Heat Exchangers are constructed according to A.S.M.E, requirements for pressures and temperature noted in table on the rear. A Manufacturers' Data Report for Pressure Vessels, Form No. U-1 as required by the provisions of the A.S.M.E. Code Rules is furnished with each unit.

This form is signed by a qualified inspector, holding a National Board Commission, and who is employed by an authorized inspection agency, certifying that construction conforms to the latest A.S.M.E. code for pressure vessels. The A.S.M.E. "U" symbol is stamped on each vessel.

\section{RECOMMENDED "WU" HEAT EXCHANGER}

MODEL NO. $89-44$

HEATING SURFACE (SQ. FT.)

\section{OPERATING DATA}

$i^{21}$

1. Fluid Circulated TUBE SIDE

2. Total Flow" ("Expressed in GPM, GPH, or lbs./hr.)

3. Temperature $\ln /$ Out Water

4. Transfer BTU/hr.

5. Pressure Drop (Maximum).

6. Fouling Factor or Percentage of Additional Surface.

Note: Following applies only for fluids other than watẹr.

7. Specific Gravity

8. Specific Heat

9. Latent Heat.

10. Viscosity"

11. Thermal Conductivity.

-. Expressed in Proper Units and Temperature such as centipoises @ ${ }^{\circ} \mathrm{F}$.

$345,200-345,200$

$2.0^{\prime} \quad 2.5^{\prime}$

.001

\section{SHELL SIDE} Water

$\frac{\frac{\frac{190}{35} / 179}{345,200}}{\frac{1.01}{.001}} \frac{\frac{\text { Water }}{35}}{\frac{120 / 140}{345,200}}$



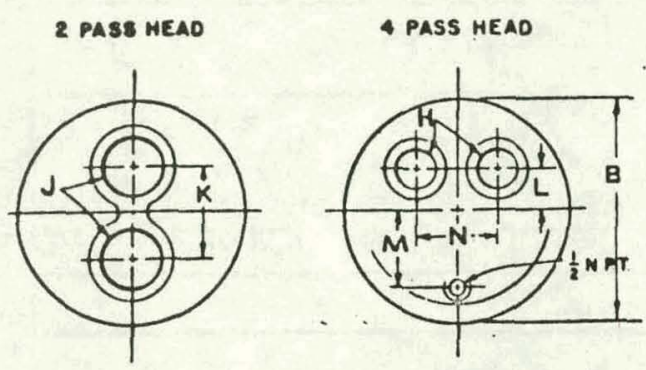

Cast iron or bolted steel legs can be supplied when specified.
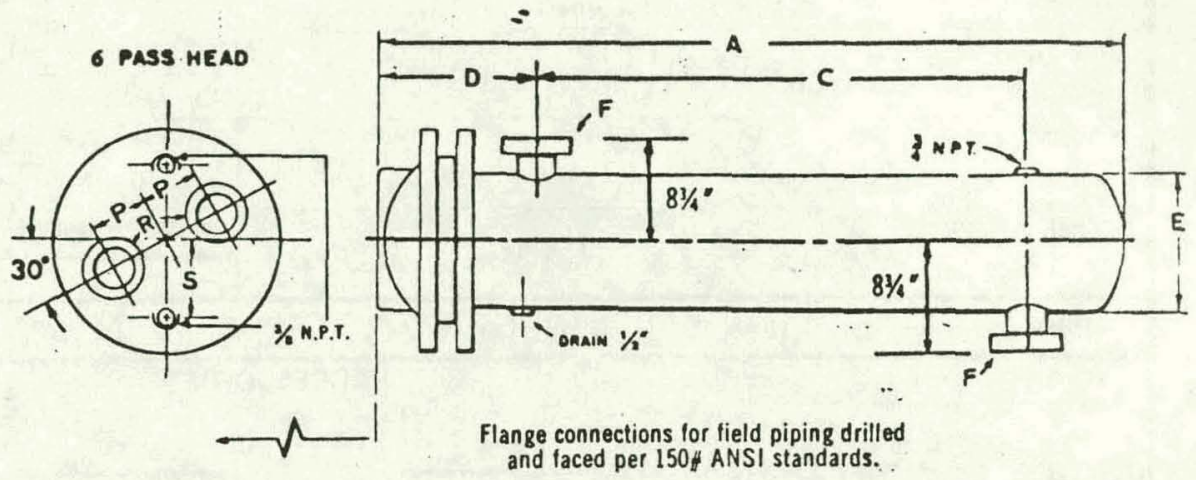

Room for removal of tube bundle, equal to or greater than " $A$ ". should be provided.

\section{DIMENSIONS}

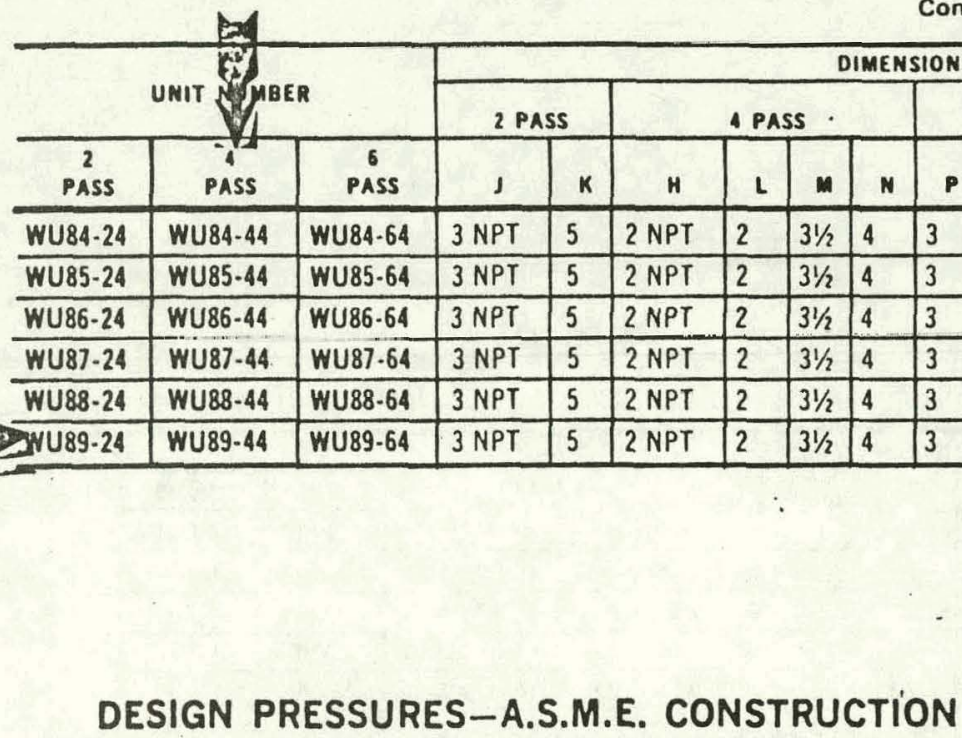 CAST IRON \& BRASS UNITS}

\begin{tabular}{|c|c|c|c|c|c|}
\hline \multicolumn{4}{|c|}{ DESIGN PRESSURES • } & \multirow{2}{*}{\multicolumn{2}{|c|}{$\begin{array}{l}\text { DESIGN TEMPERATURES } \\
\text { TUBE \& SHELL SIDE }\end{array}$}} \\
\hline \multicolumn{2}{|c|}{ TUBE SIDE } & \multicolumn{2}{|c|}{ SHELL SIDE } & & \\
\hline DESIGN & TEST & DESIGN & TEST & CAST IRON & BRASS \\
\hline 150 psi & 300 psi & 150 psi & 300 psi & $375 \mathrm{~F}$ & $300 \mathrm{~F}$ \\
\hline
\end{tabular}

- For design pressures and temperatures higher than shown,

consult $B \& G$ Representative for speciflcations and dimensions.

\section{Caution:}

A properly sized relief valve must be installed on the heated water side to protect heat exchangers from possible damage due to volumetric expansion.

\section{MATERIALS}

\begin{tabular}{l|l|l}
\hline \multicolumn{1}{c|}{ PART } & $\begin{array}{c}\text { STANDARD } \\
\text { CAST IRON UNIT }\end{array}$ & \multicolumn{1}{c}{ BRASS UNIT } \\
\hline & 2,4 \& 6 Pass & \multicolumn{1}{|c}{ 2 \& 4 Pass } \\
\hline Shell. & Steel & Steel \\
Head & Cast Iron & Cast Brass \\
Tubes 3/4" O.D. & Copper & Copper \\
Tube Sheet & Steel & Rolled Naval Brass \\
Baffles & Steel & Steel \\
Nuts \& Bolts & Steel & Steel \\
\hline
\end{tabular}

1

PAINTED IN U.S.A.8.76 


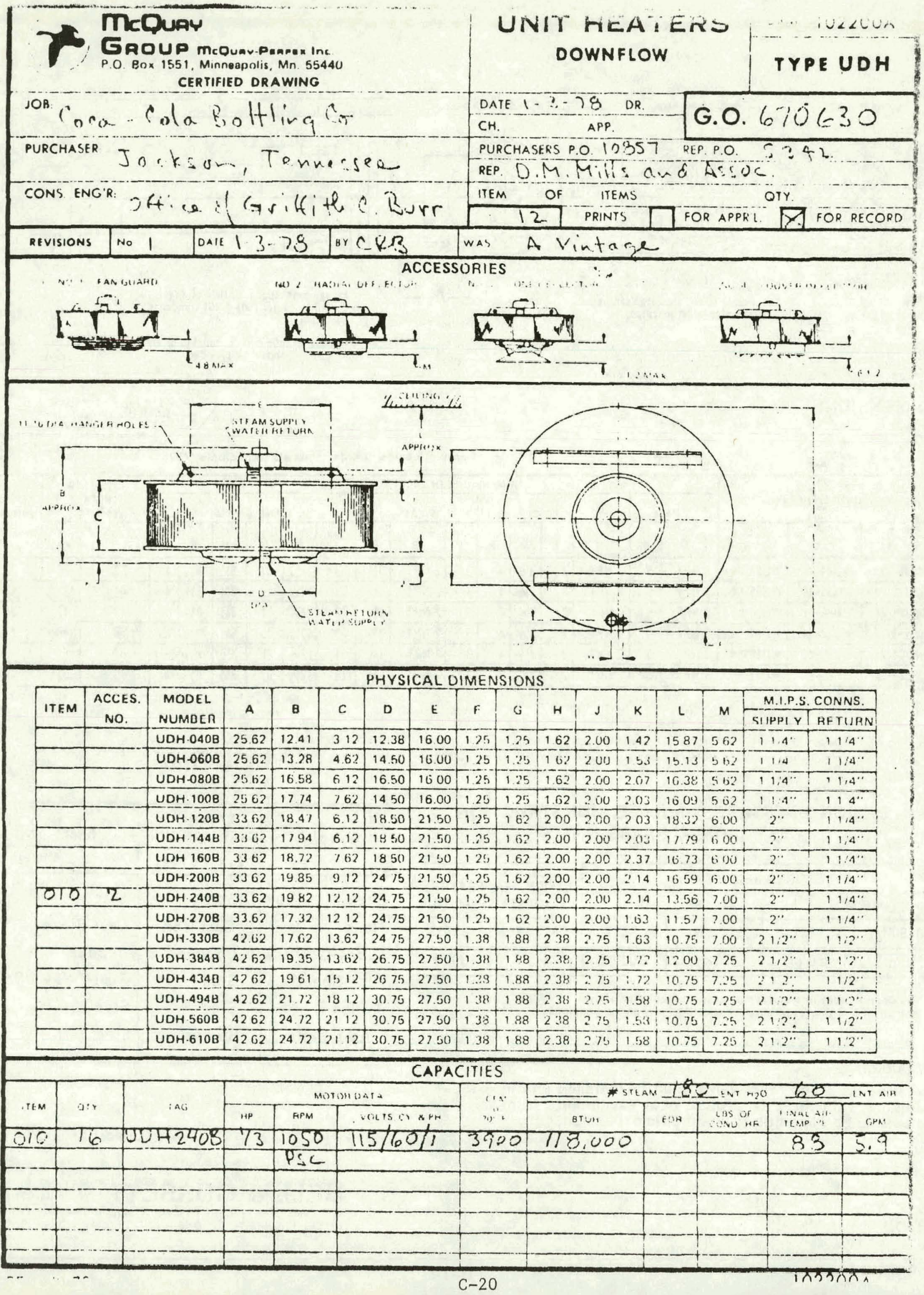


BULLETIN NO. IM 215

OCTOBER 1978

INSTALLATION \&

MAINTENANCE DATA

\section{UNIT HEATERS \\ Downflow and Horizontal \\ For Steam \& $\mathrm{H}$ ot $W$ ater Heating Systems}

\section{CONTENTS}

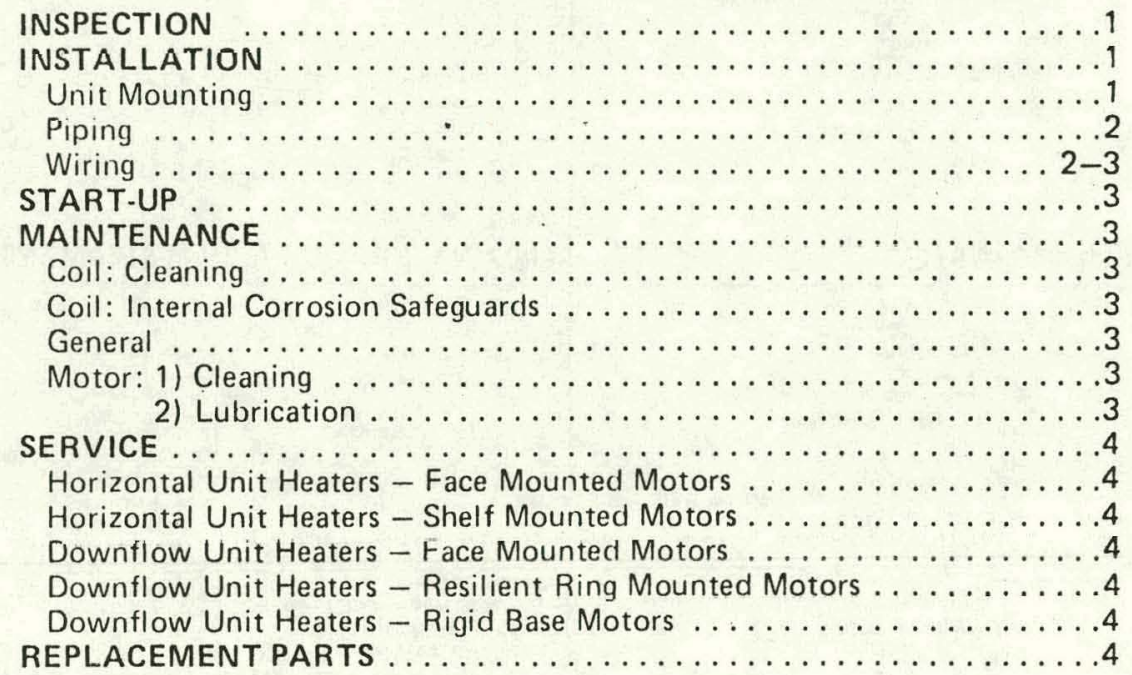

\section{INSPECTION}

When the equipment is received all items must be careiully checked against the bill of lading to be sure all cartons have been received. Visible or concealed damage should be reported immediately to the carrier and a claim filed with him for damage. The electrical nameplate should be checked to be sure it agrees with the power supply available.

\section{INSTALLATION}

Installation and maintenance are to be performed only by qualified personnel who are familiar with local codes and regulations, and experienced with this type of equipment.
CAUTION: Sharp edges and coil surfaces are a potential injury hazard. Avoid contact.

\section{UNIT MOUNTING}

Use care in handling the units to avoid damage to the coil fins. Hang units with supporting rods; do not hang units from piping. When handling the downflow unit heaters do not set the unit down on its fan blades as the fan blades may be damaged. The unit should be hung level and located with sufficient space around it for maintenance. It is suggested that 8 inches of space be left between the highest point on the downflow units and the ceiling.

The downflow unit heaters have four 11/16-inch diameter hanger holes on the top of the unit. The horizontal unit heaters have two $1 / 2-13$ weld nuts on top of the unit for threaded hanger rods.

OSHA regulations, as recorded in Federal Register Vol. 37. No. 202 in October 1972, require the use of a fan guard when the periphery of the fan blades is less than 7 feet above the floor or working surface. The customer must evaluate the location of the unit to determine if the quidelines set up by OSHA provide adequate protection against personal injury and provide protection if required. A fan guard designed to comply with OSHA requirements is available from the unit manufacturer. 
Typical piping diagrams are illustrated in Figures 1 through 4. All piping should be in conformance with good standard practice and local codes. Pipe size is based on the type of heating system, pressure and flow rate. Consult the ASHRAE guide for complete data. The selection of proper steam traps and air vents is very important. Steam traps must be properly sized and orificed for the pressure involved and should be sized for a minimum of two times the maximum condensing rate of the unit heater. In case of doubt, consult the steam trap manufacturer. Branch piping must allow for expansion and contraction without placing a strain on the unit heater. Piping should be independently supported, not supported by the unit.

Do not exceed 150 PSIG or $375^{\circ} \mathrm{F}$ temperature on standard coils, 350 PSIG or $450^{\circ} \mathrm{F}$ temperature on high pressure coils, or $300^{\circ} \mathrm{F}$ temperature on horizontal unit optional low flow water coils. The unit nameplate designates coil pressure.

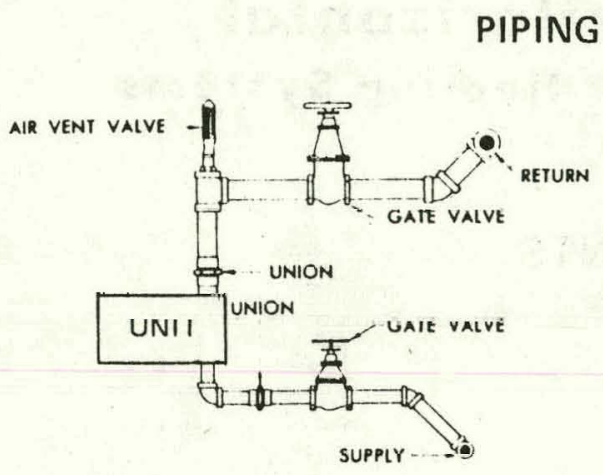

Fig. 1 HOT WATER SYSTEM

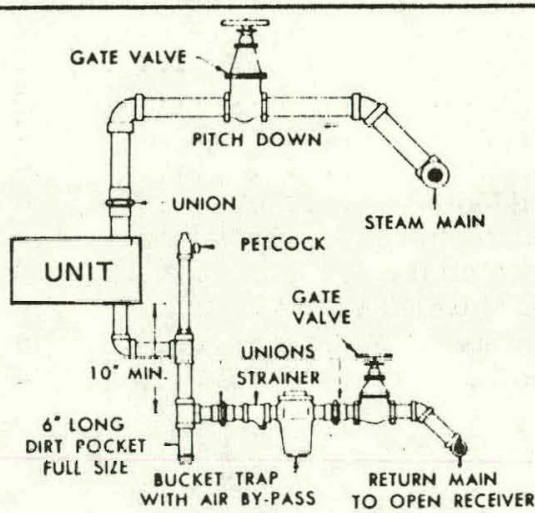

Fig. 3 HIGH PRESSURE STEAM SYSTEM

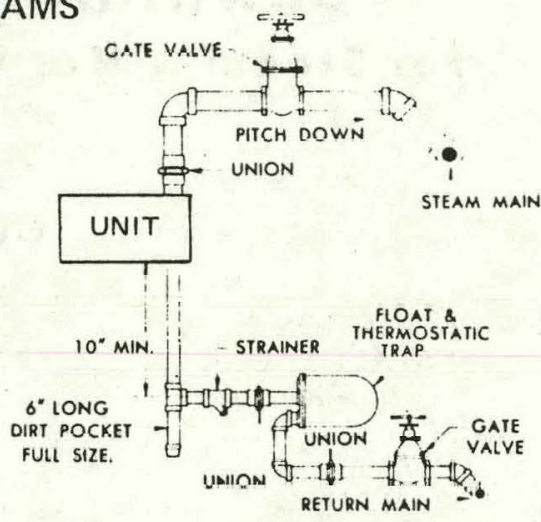

Fig. 2 VAPOR AND VACUUM STEAM SYSTEM

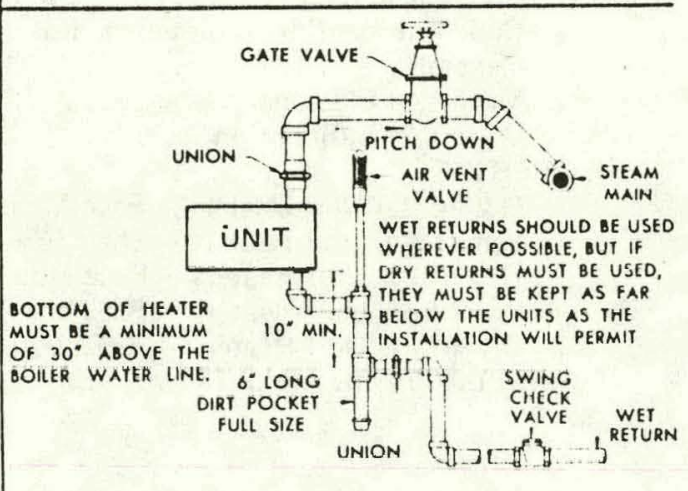

Fig. 4 LOW PRESSUHE STEAM GRAVITY SYSTEM

\section{WIRING}

Wire in accordance with local codes or the National Electric Code, whichever is applicable. The installer shall provide wiring to the motor, branch circuit overcurrent protection, and disconnect means. All standard units, except the $\mathrm{UHH}-094$ and UDH-270 and 330 with 3-phase motors and all UDH -384 through 610 , are provided with motors which have internal thermal overloads. The installer must provide overload protection for those units. Typical wiring diagrams are shown in Diagrams 1 through 6 . Wiring instruction for the optional speed controller are included with the speed controller.

Diagram 1 and 4. Although unit heaters are usually thermostatically controlled, there are some installations where manual "on-off" control is sufficient. These diagrams show this type of control. The single phase manual starter shown in Diagram 1 may be of the single pole or double pole type.
Diagram 2 and 5 . These diagrams show the most common method of controlling unit heaters. Each unit is controlled by a space thermostat and, in addition, a limit control (temperature or pressure type) is connected in the circuit so that the unit cannot operate when the temperature of the steam or water is too low.

Diagram 3 and 6 . These diagrams show the most flexible method of control providing both automatic and manual operation. The automatic operation will be the same as in Diagram 2 and 5 . However, an additional provision is made for operating the unit manually. This permits the unit being used as an air circulator during the non-heating season.

Although Diagram 6 shows a multiple application, this same type of control may be applied to individual units by substituting a magnetic starter for the magnetic relay and omitting the manual starter. 


\section{TYPICAL WIRING DIAGRAMS}

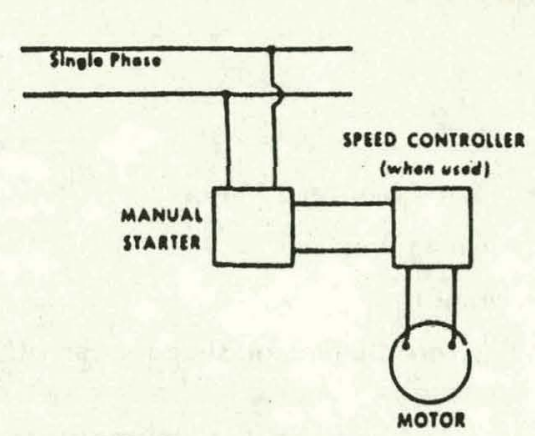

Diagram 1 - Single Phase Power MANUAL CONTROL

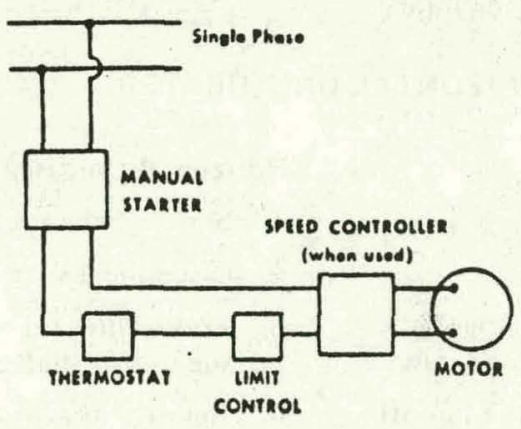

Diagram 2 - Single Phase Power AUTOMATIC CONTROL

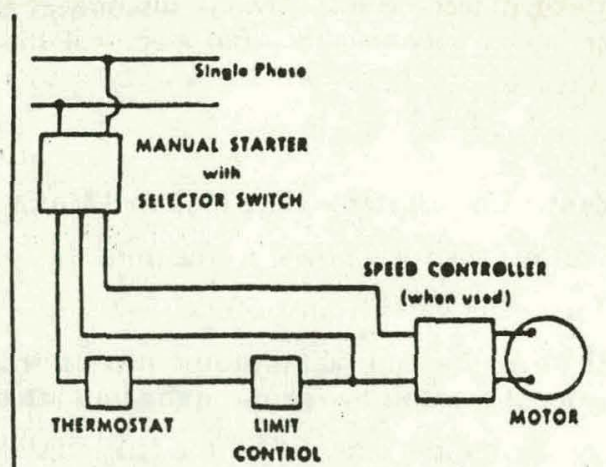

Diagram 3 - Single Phase Power MANUAL OR AUTOMATIC CONTROL

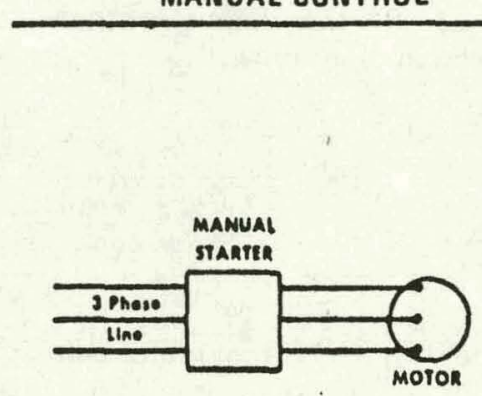

\section{Diagram 4 - 3.Phase Power MANUAL CONTROL}

\section{START-UP}

Inspect the unit heater carefully before starting. Tighten any loose nuts, bolts or screws. Examine the propeller fan to see that it has not been clamaged during installation, that it is tight on the shaft, and that it rotates freely and in the correct direction. The fan should be centered in the orifice (equal gap between fan and orifice on each side of fan), and the fan should protrude through the orifice (in direction of air flow) approximately $1 / 3$ of the blacte depth. Make sure that the line voltage at the unit is within $10 \%$ of the motor nameplate voltage. Vent the lines on hot water systems. Discharge dampers should not be closed more than $75 \%$ or motor overheating may occur.

\section{MAINTENANCE}

WARNING - Before performing any maintenance, disconnect the electrical power to avoid electrical shock or injury from rotating parts.

\section{COIL CLEANING}

All unit heater coils should be cleaned at least once a year and more often under unfavorable conditions. Build-up of dirt, grease and lint will reduce original heating capacity and may overload motor. The following are suggested cleaning methods.

1. Disconnect the electrical power before servicing to avoid electrical shock or injury from rotating parts.

2. Use a brush to loosen dirt on side where air enters the coil and then turn fan on to blow the dirt from the unit.

3. Use compressed air to loosen dirt by blowing from leaving airside of unit.

4. For a more thorough cleaning of coil, remove the fan and motor and spray a mild alkaline solution over the coil. This must be followed by a very thorough hot water rinse.
INTERNAL CORROSION SAFEGUARDS

1. Provide controlled water treatment - but do not use an excess of boiler compounds.

2. De-aerate boiler feed water.

3. Insure rapid and continous condensate drainage by proper sizing and installation of steam traps and piping.

4. Clean strainers and check steam traps for proper operation.

5. Provide proper vents for each unit. Verify annually that automatic vents are operating properly.

6. Use low pressure steam whenever possible.

GENERAL

Casings should be periodically cheaned to remove dirt, grease and corrosive substances which might injure the finish. Any rusted or corroded spots should be cleaned and repainted. Check accessories and motor mount. Also, check fan for tight connection to shaft, free rotation and proper clearance.

\section{MOTOR}

Cleaning - Disconnect the electrical power before cleaning to avoid electrical shock or injury from rotating parts. During each inspection, remove all grease and clirt from the outside of the motor. This is important as grease and dirt act as insulation and thereby prevent heat dissipation, causing overheating of the motor.

Lubrication - Sleeve bearing motors with oilers should be relubricated at the end of the first year and after each 2000 hours of operation thereafter. Use one teaspoon or $5 \mathrm{cc}$ of SAE No. 20 non-detergent oil per bearing. Where motors are operated in high ambient temperatures and/or under severe conditions, they must be serviced more frequently. DO NOT OVER-LUBRICATE. 


\section{SERVICE}

This equipment should be serviced only by qualified experienced technicians. Always disconnect the electrical power before servicing to avoid electrical shock or injury from rotating parts. If motor service is required, the motor can be removed as follows:

\section{HORIZONTAL UNIT HEATER}

\section{Horizontal Unit Heater - Face Mounted Motor}

1. Shut off electrical power to the unit.

2. Disconnect wires from motor.

3. Remove the fan guard/motor mount from the back panel of the unit by removing the four attaching screws.

4. Loosen the set screw(s) on the fan and slide the fan off the motor shaft.

5. Remove four nuts holding the motor to the fan guard/motor mount.

6. Reverse process to reassemble. Fan should be centered in the orifice and $1 / 3$ of the fan should protrude through the orifice in direction of air flow.

\section{Horizontal Unit Heater - Shelf Mounted Motor}

1. Shut off electrical power to unit.

2. Disconnect wires from motor.

3. Loosen the set screw(s) on the fan and slide the fan off the motor shaft.

4. Remove the four nuts and bolts holding the motor to the motor shelf and lift the motor off the unit.

5. Reverse process to reassemble. Fan should be centered in the orifice and $1 / 3$ of the fan should protrude through the orifice in direction of air flow.

\section{DOWNFLOW IINIT HF}

\section{Downflow Unit Heater - Face Mounted Motor}

1. Shut off electrical power to the unit.

2. Disconnect wires from the motor.

\section{Top removal}

3. Loosen the set screw(s) on the fan and slide the fan off the motor shaft.

4. Remove the four nuts holding the motor to the bottom motor pan.

5. Lift motor out of the top of unit. Proceed to Step 6.

Bottom removal

3. Remove four screws holding bottom motor pan to motor cylinder. Lower fan motor and motor pan assembly out the bottom of the unit.

4. Loosen the set screw(s) on the fan and slide the fan off the motor shaft.

5. Remove the four nuts holding the motor to the bottom motor pan. Proceed to Step 6.

6. Reverse process to reassemble. Fan should be centered in the orifice and $1 / 3$ of the fan should protrude through the orifice in direction of air flow.

Downflow Unit Heater - Resilient Ring Mounted Motor

1. Shut off electrical power to the unit.

2. Disconnect wires from the motor.

3. Loosen the set screw(s) on the fan and slide the fan off the motor shaft.

Top removal

4. Disconnect the bracket at the top of the motor.

5. Lift the motor out of the top of the unit. Proceed to Step 6.

\section{Bottom remuval}

4. Remove the four screws holding the bottom motor pan to the motor rylinder.

5. Lower motor pan and motor out the bottom of the unit. Proceed to Step 6.

6. Reverse process to reassemble. Fan should be centered in the orifice and $1 / 3$ of the fan should protrucle through the orifice in direction of air flow.

\section{Downflow Unit Heater - Rigid Base Motor}

1. Shut off electrical power to the unit.

2. Disconnect wires from the motor.

3. Loosen the set screw(s) on the fan and slide the fan off the motor shaft.

Top removal

4. From top of unit, reach down and remove the four bolts that attach the motor to the plate in the motor cylinder.

5. Lift the motor out the top of the unit. Proceed to Step 6.

\section{Bottom removal}

4. From bottom of unit, remove the screws holding the bottom motor pan to the motor cylinder.

5. Remove the four bolts that attach the motor to the plate in the cylinder and lower the motor out the bottom of the unit. Proceed to Step 6.

6. Reverse process to reassemble. Fan should be centered in the orifice and $1 / 3$ of the fan should protrucle through the orifice in direction of air flow.

\section{REPLACEMENT PARTS}

When writing for service or replacement parts always provide a complete description of the service part, part number (if known), plus complete serial and model number of unit involved. 
McQuay certifles that it will furnish equipment in accordance with this LOW AND MEDIUM PRESSURE HORIZONTAL DRAW THRU

of its home office.

\section{GENERAL SPECIFICATIONS}

CABINET - GALVANIZED STEEL STRUCTURAL FRAME AND PANELS. ACCESS DOORS AND REMOVABLE PANELS PROVIDE COMPLETE ACCESSIBILITY TO INTERIOR.

FANS - GALVANIZED STEEL DYNAMICALLY BALANCED. BLADES RIVETED TO RIMS AND CENTER PLATE. CAST IRON HUBS.

HOUSINGS - GALVANIZED STEEL, DIE FORMED WITH SPOT WELDED SEAMS.

SHAFTS - SOLID HIGH CARBON STEEL SIZED SO THAT THE OPERATING SPEED IS WELL BELOW THE FIRST CRITICAL SPEED SPEED

SHEAVES - MACHINED CAST IRON, "V" GROOVE TYPE, KEY SEATED TO SHAFT.
MOTOR MOUNT - ADJUSTABLE FOR VARYING BELT TEN. SION.

BEARINGS - SELF ALIGNING, BALL TYPE WITH GREASE FITTINGS AND EXTENDED LUBE LINES.

BELT GUARDS - GALVANIZED STEEL WITH FAN SHAFT BEL HOMEARR - GALVAN

INSULATION - NEOPRENE COATED I" GLASS FIBER. MEETS NASLATON

DRAINPAN - GALVANIZED STEEL INNER PAN COVERED DRAINPAN - GALVANIZED STEEL INNER PAN COVERED ISOLATED FROM BOTTOM PAN WITH I" GLASS FIBER IN ISOLATEO
SULATION

$23 / 4 "$ DIA. MOUNTING HOLES

(WHEN REQUIRED - TOP OR BOTTOM)

6 MOUNTING HOLES
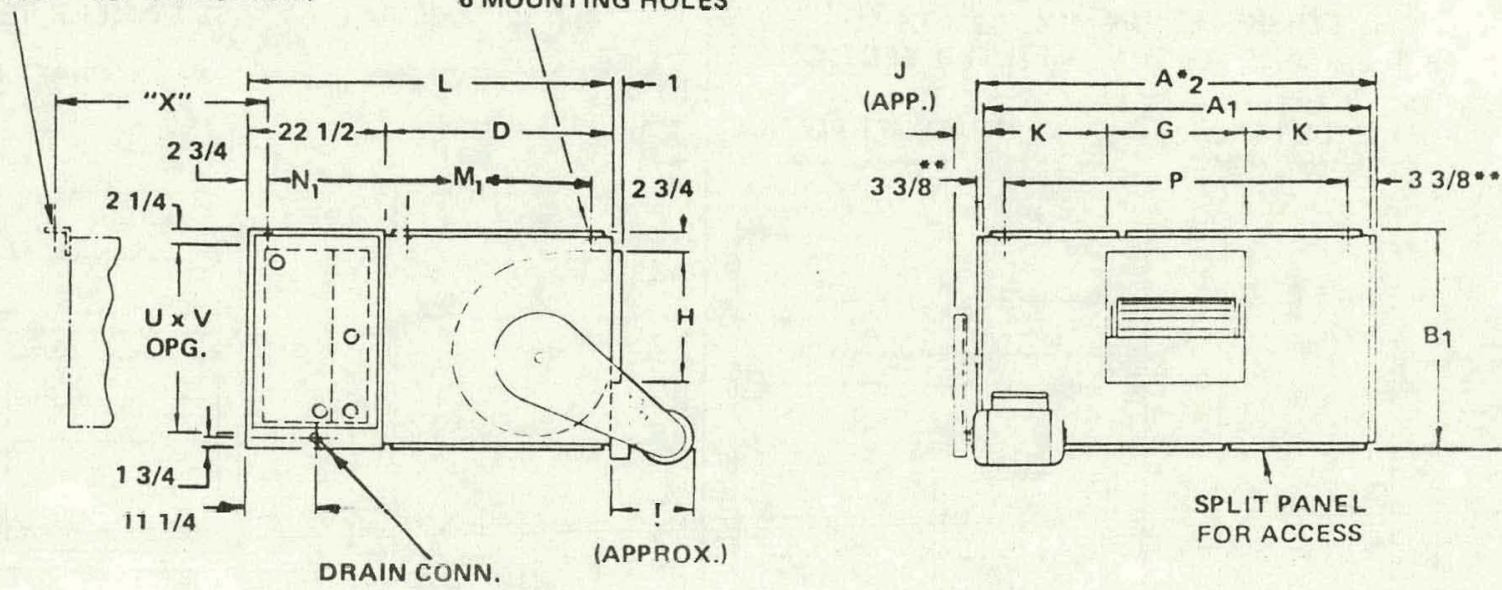

SPLIT PANEL

FOR ACCESS

$11 / 4$ MPS BOTH ENDS

NOTES:

1. $A_{1} \& B_{1}$ DIMENSIONS FOR BLOWER SECTION

$A_{2} \& B_{1}$ DIMENSIONS FOR COIL SECTION

2. "X" DIMENSION FOUND BY ADDING DIMENSION OF THE

OPTIONAL SECTIONS USED PLUS $35 / 8$ IN. INCLUDE $1 / 8$ "

FOR GASKETING WHERE SECTIONS BOLT TOGETHER

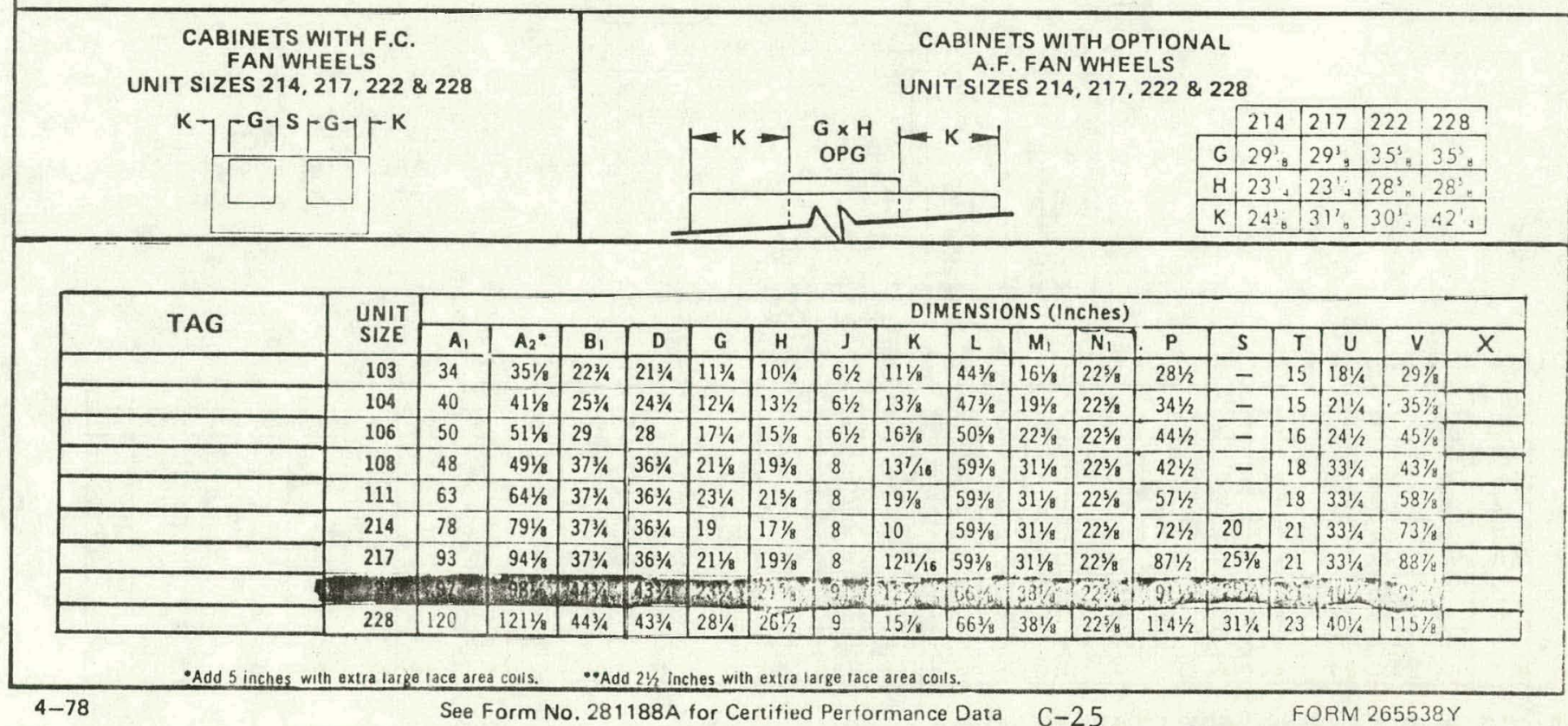




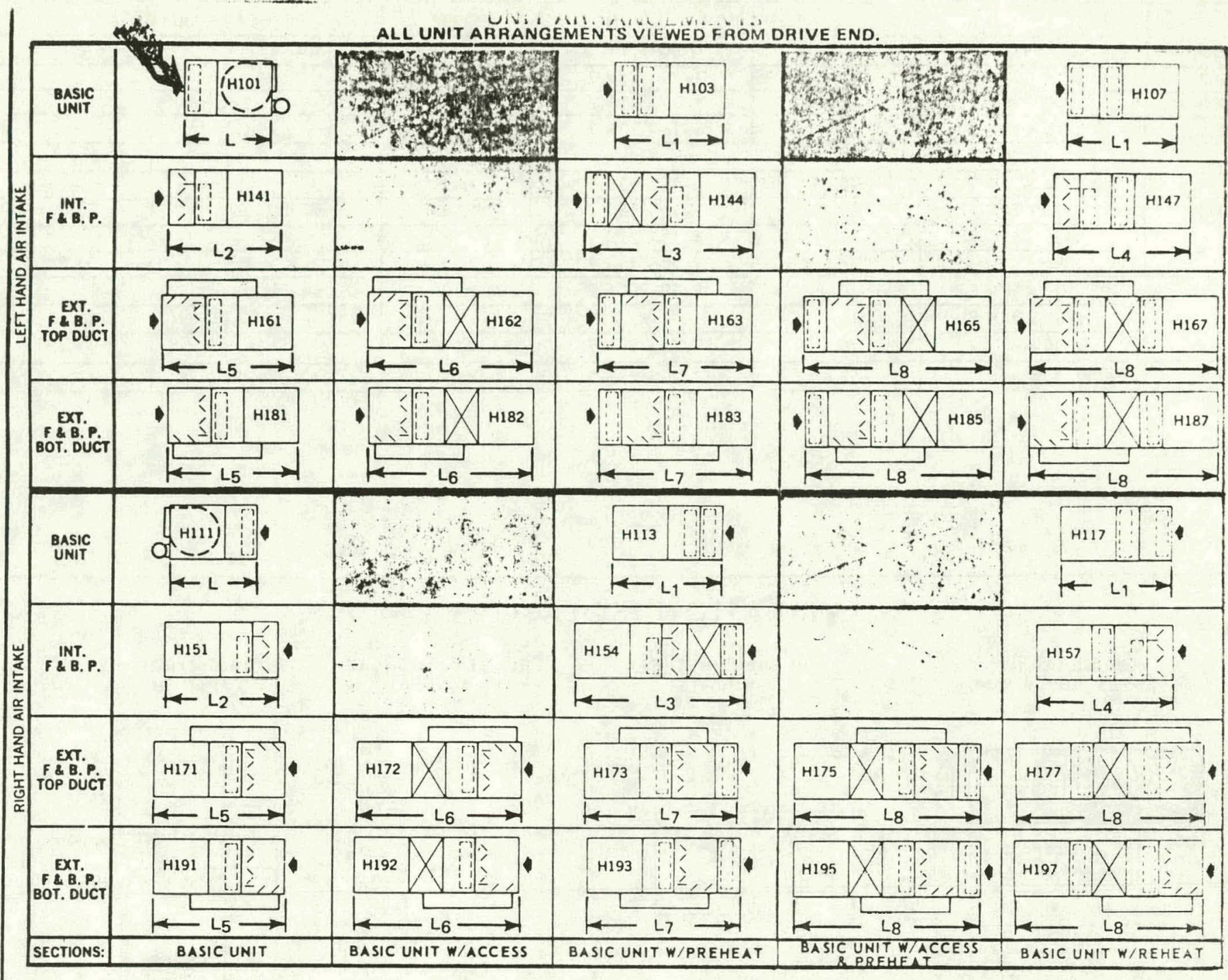

\begin{tabular}{|c|c|c|c|c|c|c|c|c|c|}
\hline \multirow{2}{*}{$\begin{array}{l}\text { UNIT } \\
\text { SIZE } \\
\end{array}$} & \multicolumn{9}{|c|}{ DIMENSIONS (Inches) } \\
\hline & $\mathrm{L}$ & $\mathbf{L}_{1}^{*}$ & $\mathrm{~L}_{2}$ & $\mathrm{~L}^{\circ}$ & $\mathrm{L}^{\circ}$ & Ls & $L_{6}$ & $L 7^{\circ}$ & $L 0^{\circ}$ \\
\hline 103 & $44 \%$ & 51 & $51 \%$ & 76 & $57 \%$ & $52 \frac{1}{2}$ & $701 / 2$ & 59 & $77 \%$ \\
\hline 104 & $47 \%$ & 54 & $551 / 2$ & $801 / 4$ & $621 \%$ & $55 \%$ & $73 \frac{1}{4}$ & $62 \%$ & $80 \%$ \\
\hline 106 & $50 \%$ & $57 \%$ & $59 \%$ & $84 \frac{1}{2}$ & $66 \frac{1}{6}$ & $59 \%$ & 78 & $661 / 2$ & $84 \%$ \\
\hline 108 & $59 \%$ & 66 & $681 / 2$ & $93 \%$ & $75 \%$ & $70 \frac{1 / 2}{2}$ & $88 \%$ & $77 \frac{1}{6}$ & $951 / 4$ \\
\hline 111 & $59 \%$ & 66 & $681 / 2$ & $93 \%$ & $75 \%$ & $70 \%$ & $88 \%$ & $77 \%$ & $951 / 4$ \\
\hline 214 & $59 \%$ & 66 & $681 / 2$ & $931 / 4$ & $75 \%$ & $701 / 2$ & $88 \%$ & $77 \%$ & $951 / 4$ \\
\hline 217 & $591 \%$ & 66 & $681 / 2$ & $93 \%$ & $75 \%$ & $701 / 2$ & $88 \%$ & $77 \%$ & $95 \%$ \\
\hline 222 & $66 \%$ & $73 \frac{1}{2}$ & $74 y_{4}$ & 100 & $81 \%$ & $79 \%$ & 98 & 87 & $1051 / 3$ \\
\hline 228 & $66^{1 / 1}$ & $731 / 2$ & $74 \%$ & 100 & $81 \%$ & $79 \%$ & 98 & 87 & $1051 / 4$ \\
\hline
\end{tabular}

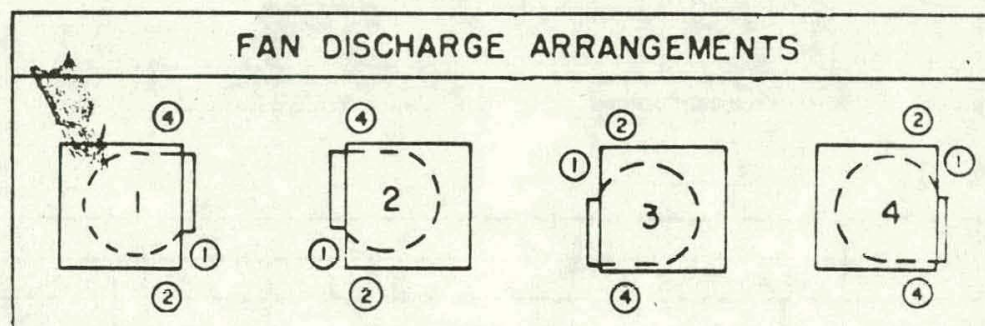

\section{NOTE:}

FOR OVERALL UNIT

LENGTH ADD DIMENSIONS

OF ACCESSORIES NOT

INCLUDED IN ABOVE "L" DIMENSION

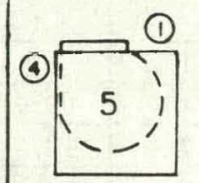

(3)

ACCESSORY ARRANGEMENTS

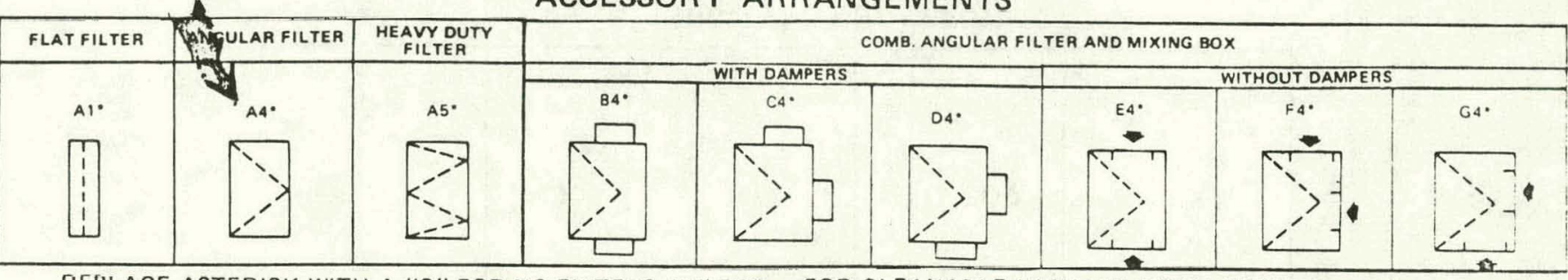

REPLACE ASTERISK WITH A "O" FOR NO FILTERS, "1" FOR FOR CLEANABLE HIGH VELOCITY FILTERS AND A "4" FOR THROWAWAY FILTERS, "2" FOR CLEANABLE FILTERS, "3" THROWAWAY HIGH PERFORMANCE FILTERS. 
. 1

\begin{tabular}{|c|c|c|c|c|c|c|}
\hline \multirow{2}{*}{$\begin{array}{l}\text { UNIT } \\
\text { SIZE }\end{array}$} & \multicolumn{2}{|l|}{ FLAT } & \multicolumn{2}{|c|}{ ANGULAR } & \multicolumn{2}{|c|}{ HEAVY DUTY } \\
\hline & QUANTITY & AREA & QUANTITY & AREA & QUANTITY & AREA \\
\hline 103 & $2-16 \times 20 \times 2$ & 4.4 & $2-16 \times 25 \times 2$ & 5.6 & - & - \\
\hline 104 & $2-20 \times 20 \times 2$ & 5.6 & $4-16 \times 20 \times 2$ & 8.9 & - & - \\
\hline 106 & $3-16 \times 25 \times 2$ & 8.4 & $6-16 \times 20 \times 2$ & 13.3 & - & - \\
\hline \multirow{2}{*}{108} & $2-16 \times 20 \times 2$ & - & - & - & - & - \\
\hline & $2-16 \times 25 \times 2$ & 10.0 & $6-16 \times 25 \times 2$ & 16.7 & - & - \\
\hline 111 & $6-16 \times 20 \times 2$ & 13.3 & $6-20 \times 25 \times 2$ & 20.8 & $9-20 \times 20 \times 2$ & 25.0 \\
\hline \multirow{2}{*}{214} & $6-16 \times 25 \times 2$ & 16.7 & $4-16 \times 25 \times 2$ & - & - & - \\
\hline & - & - & $4-20 \times 25 \times 2$ & 24.9 & $9-20 \times 25 \times 2$ & 31.2 \\
\hline \multirow[b]{2}{*}{217} & $4-16 \times 20 \times 2$ & 20.0 & $8-20 \times 25 \times 2$ & 27.8 & $9-20 \times 20 \times 2$ & \\
\hline & $4-16 \times 25 \times 2$ & - & - & - & $6-16 \times 20 \times 2$ & 38.3 \\
\hline 222 & $12-16 \times 20 \times 2$ & 26.7 & $12-16 \times 25 \times 2$ & 33.4 & $24-16 \times 20 \times 2$ & 53.3 \\
\hline 228 & $12-20 \times 20 \times 2$ & 33.4 & $12-20 \times 25 \times 2$ & 41.8 & $24-20 \times 20 \times 2$ & 66.6 \\
\hline
\end{tabular}

\section{VIBRATION ISOLATORS}

SPRING MOUNTS TYPES "BP" \& "CP"
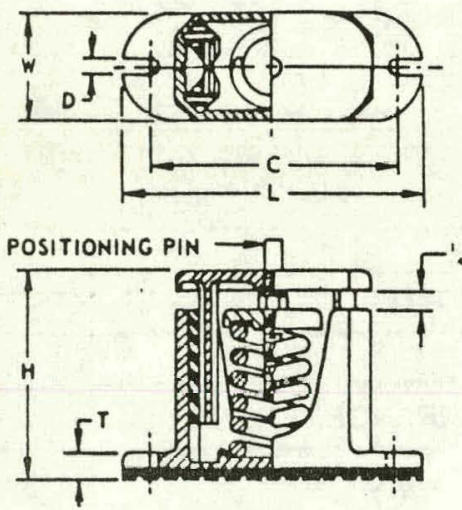

RUBBER - IN - SHEAR MOUNTS TYPE "RP"
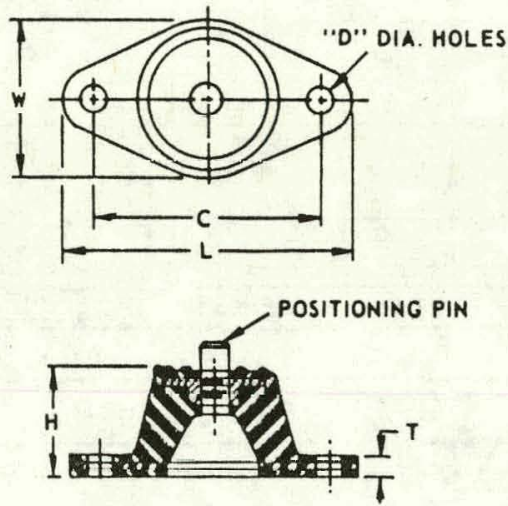

RUBBER - IN - SHEAR HANGER TYPE "RH"

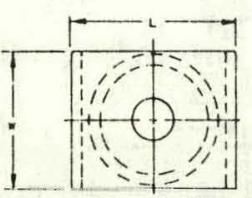
PROVISIOU FOR

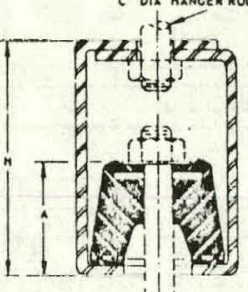

SPRING HANGER

TYPE "SH"
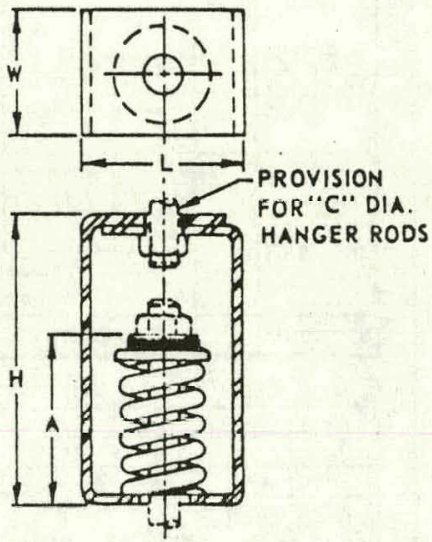

\begin{tabular}{|c|c|c|c|c|c|c|c|c|c|c|c|c|}
\hline \multirow{2}{*}{ DIMENSIONS } & \multicolumn{12}{|c|}{ ISOLATORS } \\
\hline & $B P$ & CP1 & CP2 & RP1 & RP2 & RP3 & RP4 & $\mathrm{RH} 2$ & $\mathrm{RH}_{3}$ & $\mathrm{RH}_{4}$ & $\mathrm{SH}$ & SH5 \\
\hline A & - & - & - & - & - & - & - & $13 / 8$ & 2 & 2 & $43 / 8$ & $31 / 8$ \\
\hline C & 5 & $61 / 2$ & $91 / 4$ & $23 / 8$ & 3 & $41 / 2$ & 5 & $5 / 8$ & $3 / 4$ & 1 & $3 / 4$ & $1 / 2$ \\
\hline D & $7 / 16$ & $5 / 8$ & $5 / 8$ & $11 / 32$ & $11 / 32$ & $9 / 16$ & $9 / 16$ & - & - & - & - & - \\
\hline$* \mathrm{H}$ & $37 / 8$ & 5 & $51 / 4$ & 1 & $11 / 4$ & $13 / 4$ & $13 / 4$ & $41 / 2$ & $53 / 4$ & 8 & 7 & $41 / 2$ \\
\hline$L$ & $55 / 8$ & $71 / 2$ & $101 / 4$ & 3 & $37 / 8$ & $51 / 2$ & $61 / 2$ & 3 & $33 / 4$ & $43 / 4$ & $33 / 4$ & $33 / 4$ \\
\hline$T$ & $1 / 2$ & $5 / 8$ & $5 / 8$ & $1 / 4$ & $1 / 4$ & $1 / 4$ & $1 / 4$ & - & - & - & - & - \\
\hline$w$ & $21 / 8$ & $23 / 4$ & $23 / 4$ & $15 / 8$ & $23 / 8$ & $33 / 8$ & $41 / 4$ & $21 / 4$ & $31 / 4$ & 4 & 3 & $21 / 4$ \\
\hline
\end{tabular}

- Operating Height

*OPERATING HEIGHT.

ISOLATOR LOCATIONS

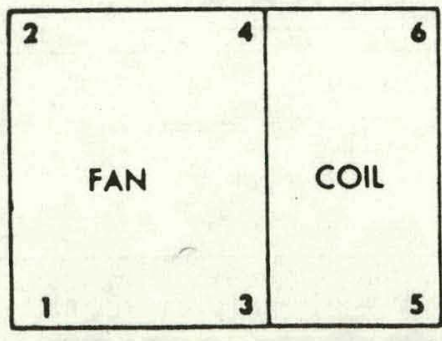

WITHOUT ACCESSORIES

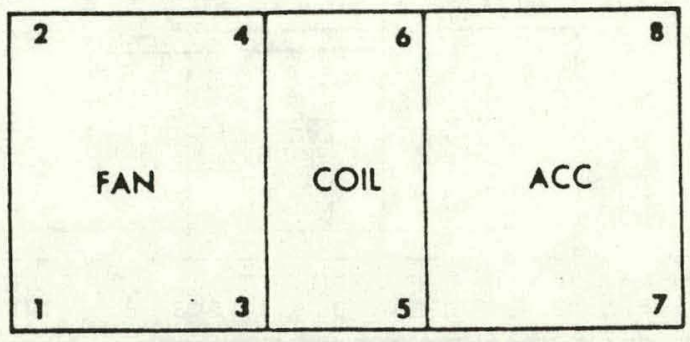

WITH ACCESSORIES 


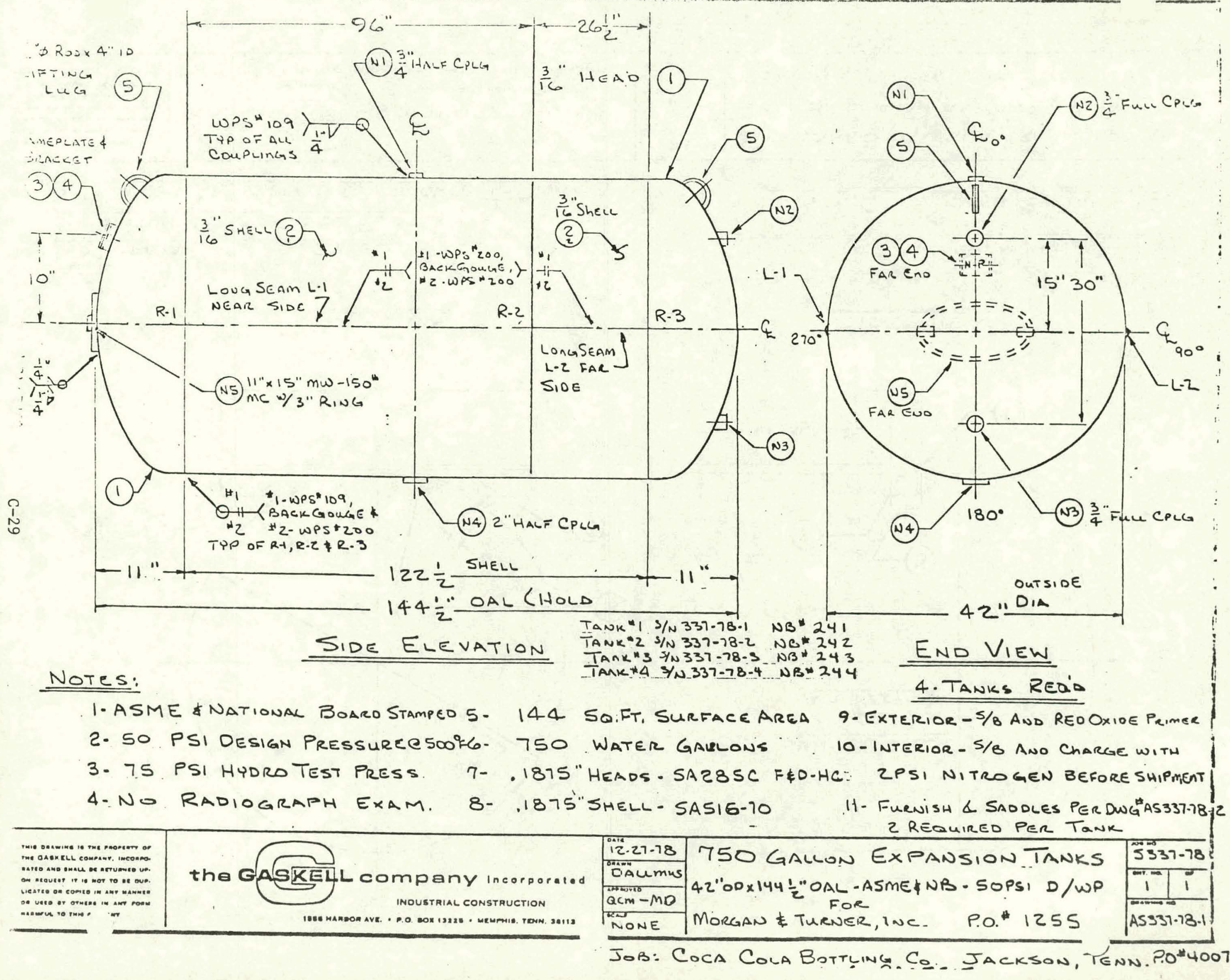




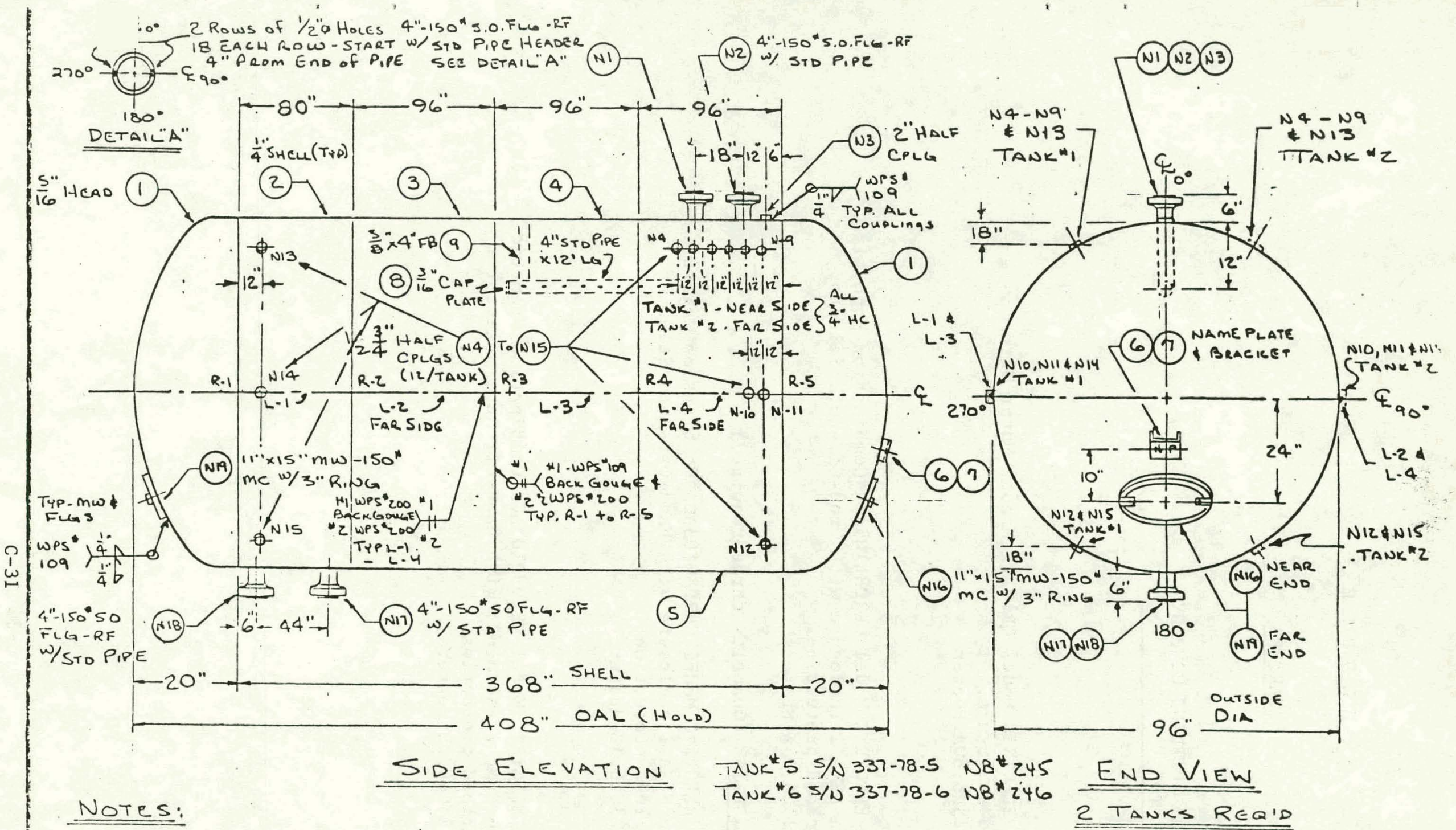

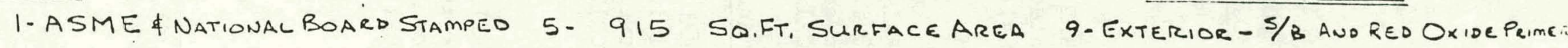

2. 50 PSI DESIGN PRESSUREC500\%6- 12,000. WATER GALLONS

3. 75 PSI HYDRD TEST PRESS. 7-.3125" HEAdS-5A516-10 FID. I. 2 PSI NITROGEN BEFORE SIHIPMEAT

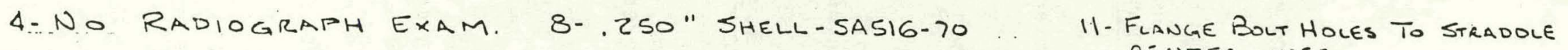
CENTER LINES

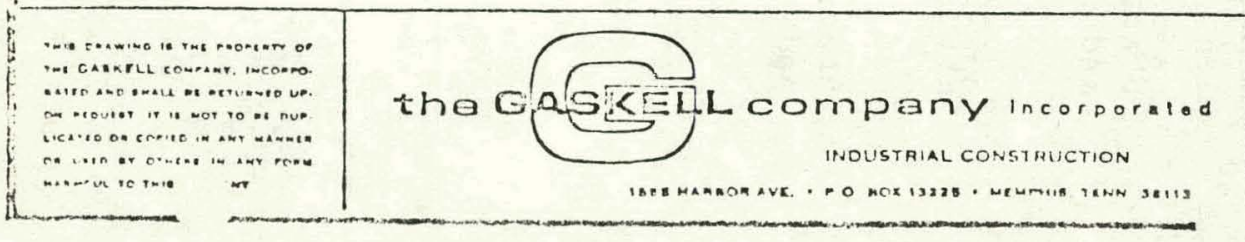

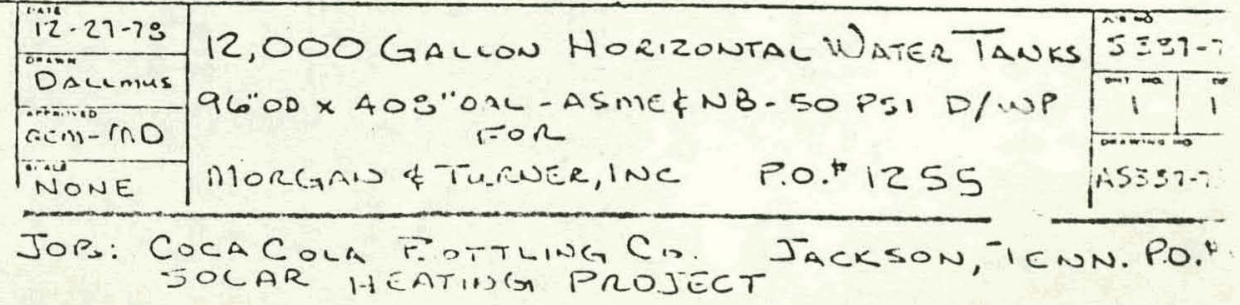




\section{STAR'TERS}

PROJECT: COCA COLA BOTTLING COMPANY JACKSON, TN

UNIT HEATERS

GENERAL ELECTRIC Model CRIOIYI Manual Motor Watchman In surface mounted enclosure.

1 - CR123116.80A Heater

PUNP P-1

GENERAL ELECTRIC Model CR208B103ACA Combination Magnetic Starter, size 0 in NEMA 1 enclosure with lland-Off-Auto Selector, and three-log overload protection.

3 - CR123C6.95A Heaters

PUMl'S P-2, P-3 and P-3A (Quantity three required)

GENERAL L'LECTRTC Model CR208C103ACA Combination Magnetic Starter, Size 1 in NEMA 1 enclosure with Hand-Off-Auto Selector and three-leg overload protection.

3 - CR123C16.3B Heaters

PURCE FAN

GENERAL ELECTRIC Model CR208D103ACA Conbination Magnetic Starter, Size 2 in NEMA 1 enclosure with Hand-Off-Auto Selector and three-leg overload protection.

3 - CR123C44.OB Heaters 
Noy UUILOL

\section{L manual motor stanteres}

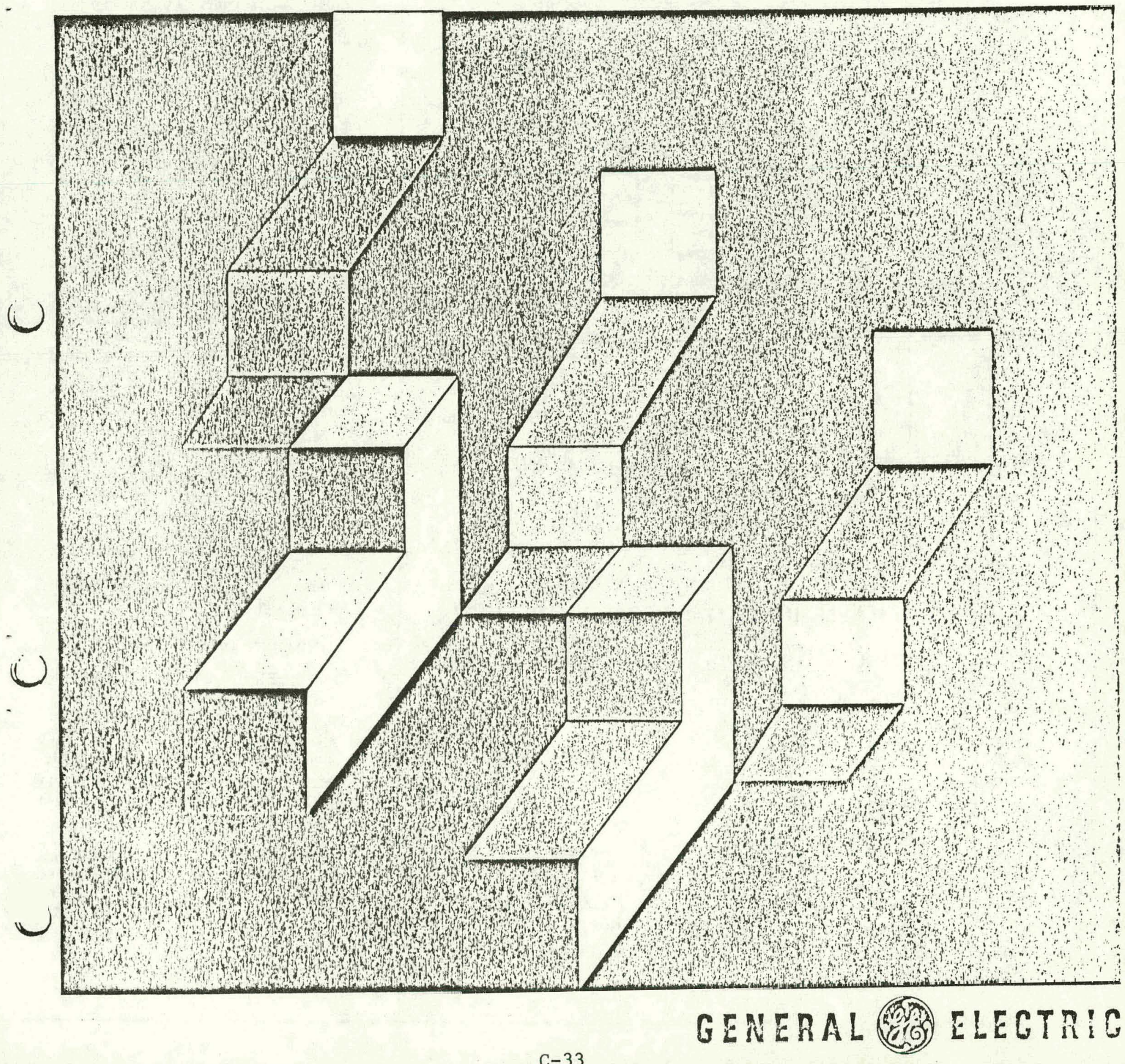




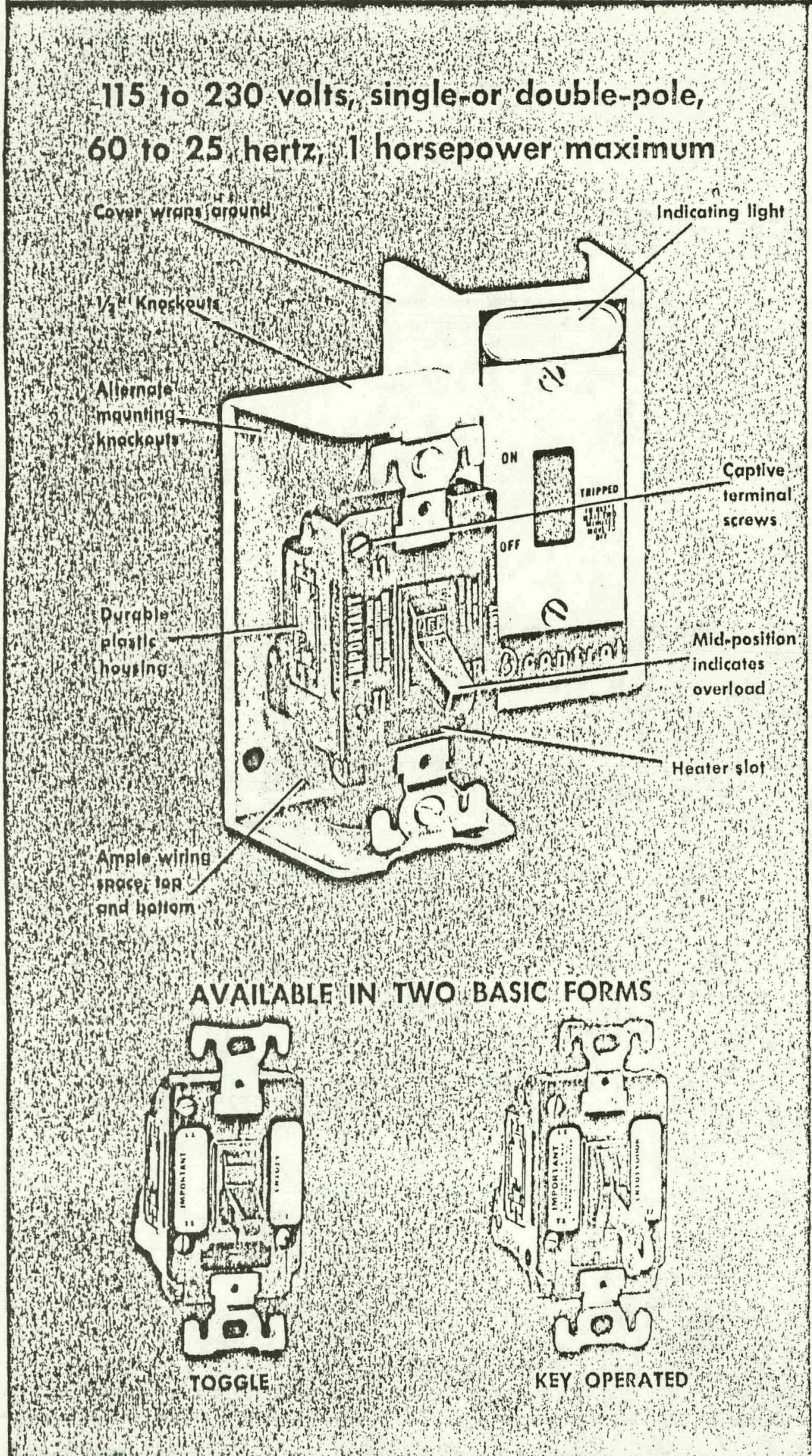

General Electric's CR101 manual starter is designed for use on single-phase fractional-horsepower motors. It provides dependable overload protection for general purpose motors and it is the most economical starter choice for ap. plications requiring no undervoltage protection. Typical applications inclucle grinders, conveyors, hydraulic presses, blowers and mixers.

The CR101 manual starter offers many measurable advantages - distinct and valuable advantages over other makes of starters - which can silve time and money in your operation. The chief measurable advantanes are illustrated at the right.

\section{DEPENDABLE OVERLOAD PROTECTION}

Positive bimetallic overload protection is provided by the thermal protective device which automatically opens the contacts when an overload occurs, and removes the motor from the line. The thermal overload device includes heater (a coil of resistance wire) which simulates the motor temperature.

The heater is designed to follow the heating curve of the motor. If the motor is overloaded, the excess current passing through the heater radiates additional heat, which caluses a bimetallic strip to bend. Bending the strip causes the starter contacts to open. This bimetallic strip will not trip on momentary overloads such as starting currents, but will guard the motor against even small persistent overloads.

Under overload conditions, the switch handle moves to the mid-position, giving a positive indication that an overload has occurred. The bimetal. lic mechanism is completely trip-free, so that contacts cannot be reclosed until the bimetallic strip cools. To resturt after overload, turn starter to OFF and then to $O N$.

\section{A COMPLETE LINE}

General Electric's CR101 manual starter is available in two basic forms; toggle or key-operated. Each form is offered as either single- or clouble-pole. In addition, this starter may be ordered in open or general-purpose, dust- and watertight and hazardous-location enclosures. Twospeed and combination forms are a!so available.

General Electric offers the widest variety of cover plates, flush plates, and accessory kits in the inclustry. As a r sult, you can select or assemble th exact starter you need to meet any fhp motor application. 


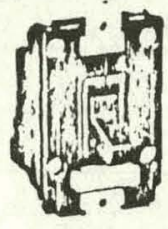

Open starter (toggle operated)

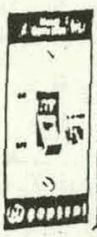

General-purpose starter

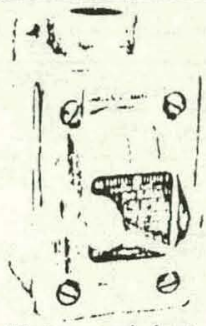

Water-and dusttight starter

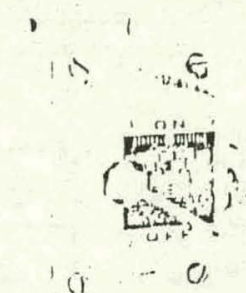

Haxardous location starter

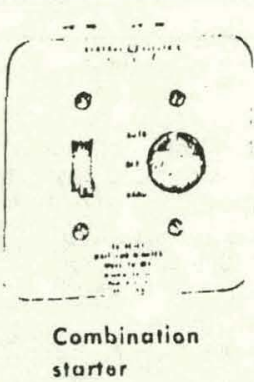

startor

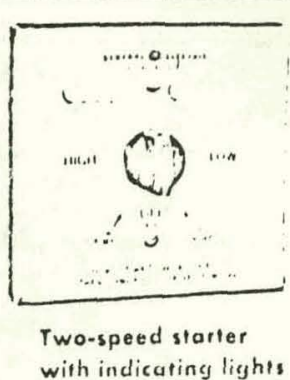

with indicatines lights

Single-phase Fractional Horsepower - 1 HP Maximum on 115 or 230 Volts, 60 to 25 Hertz

STANDARD FORMS

\begin{tabular}{|c|c|c|c|c|c|}
\hline \multirow{2}{*}{$\begin{array}{l}\text { No. of } \\
\text { Poles }\end{array}$} & \multirow{2}{*}{$\frac{\text { Open }}{\begin{array}{c}\text { For Flush or } \\
\text { Outlet Box Mig. }\end{array}}$} & \multicolumn{2}{|c|}{ General-purpose, NEMA Typo 1} & \multirow{2}{*}{$\begin{array}{l}\text { Water- and } \\
\text { Dust-tight, } \\
\text { NEMA Type } 4\end{array}$} & \multirow{2}{*}{$\begin{array}{c}\text { Hazardous - location. NEMA } \\
\text { Types } 7 \text { and } 9, \text { (Class } I \text {, } \\
\text { groups } C \text { and } D, \text { Class } I_{1} \\
\text { groups } E, F \text { and } G \text { ) }\end{array}$} \\
\hline & & Surface-mtg. & $\begin{array}{l}\text { Surface.mtg. } \\
\text { W/Ind. LIght }\end{array}$ & & \\
\hline \multicolumn{4}{|c|}{ TOGGLE-OPERATED } & \multicolumn{2}{|c|}{ LEVER-OPERATED-3/4" hub on one end } \\
\hline $\begin{array}{l}1 \\
2\end{array}$ & $\begin{array}{l}\text { CH101 Y } \\
\text { CR101 H }\end{array}$ & $\begin{array}{l}\text { CRIOL Y1 } \\
\text { CRIOI HI }\end{array}$ & $\begin{array}{l}\text { CR101 Y11 } \\
\text { CH101 H11 }\end{array}$ & $\begin{array}{l}\text { CRIO1 Y40OH } \\
\text { CH101 H40OH }\end{array}$ & $\begin{array}{l}\text { CRIO1 Y7OOH } \\
\text { CRIOI H7OOUH }\end{array}$ \\
\hline \multicolumn{4}{|c|}{ KEY-OPERATED } & \multicolumn{2}{|c|}{ LEVER-OPERATED- $3 / 4^{\prime \prime}$ hub on both ends } \\
\hline 1 & CRIOI YOOOK & CR101 Y100K & CR101 Y110K & CR101 Y400J & CRIO1 Y700J \\
\hline 2 & CRIOI HOOOK & CR101 H1OOK & CR101 H11OK & $\mathrm{CH} 101 \mathrm{H} 400 \mathrm{~J}$ & CRIOI HOOOJ \\
\hline
\end{tabular}

TWO-SPEED FORMS

\begin{tabular}{|c|c|c|c|c|}
\hline \multirow{2}{*}{$\begin{array}{l}\text { No. of } \\
\text { Poles }\end{array}$} & \multirow{2}{*}{$\begin{array}{l}\text { Indicat- } \\
\text { ing } \\
\text { Lights }\end{array}$} & \multirow{2}{*}{\begin{tabular}{|c|}
$\begin{array}{c}\text { General Purpose, } \\
\text { NEMA TyHL 1 }\end{array}$ \\
$\begin{array}{c}\text { Surface- } \\
\text { mounting }\end{array}$
\end{tabular}} & \multicolumn{2}{|c|}{ General-purpose, Flush-mountinq } \\
\hline & & & $\begin{array}{c}\text { Gray } \\
\text { Flushl-plate }\end{array}$ & $\begin{array}{l}\text { Stainless-steel } \\
\text { Flush-plat: }\end{array}$ \\
\hline $\begin{array}{l}1 \\
1 \\
2 \\
2\end{array}$ & $\begin{array}{l}\text { None } \\
\text { Two } \\
\text { None } \\
\text { Iwo }\end{array}$ & $\begin{array}{ll}\text { CRIOI YGOOB } \\
\text { CRIOI YG1OH } \\
\text { CR101 HGOOH } \\
\text { CH101 HGIOH }\end{array}$ & $\begin{array}{l}\text { CRIOI YGOOA } \\
\text { CRIOL YGIOA } \\
\text { CRIOI HGOOA } \\
\text { CHIOI HGIOA }\end{array}$ & 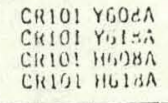 \\
\hline \multicolumn{5}{|c|}{ COMBINATION FORMS } \\
\hline \multicolumn{2}{|c|}{$\begin{array}{l}\text { No. of } \\
\text { roles }\end{array}$} & \multicolumn{3}{|c|}{ Catalog Number } \\
\hline & $\begin{array}{l}2 \\
2\end{array}$ & \multicolumn{3}{|c|}{$\begin{array}{l}\text { Note: Do not use Selector Switch } \\
\text { to interrupt motor power. }\end{array}$} \\
\hline
\end{tabular}

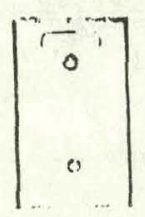

Standard flush plate with Indicating IIght, machine gray finlsh (CR101 X1)

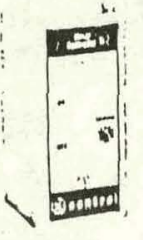

Standard front cover for surface mounting (CR101 X5)

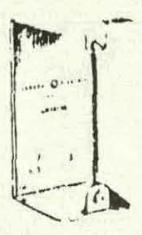

Back box (CR101 X8) mounting

(CR101 X6)

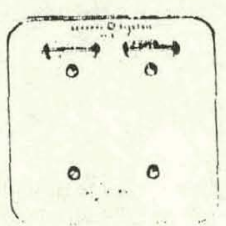

Combination flush piate with indicating lights for flush or surface mounting (CR101 X13)
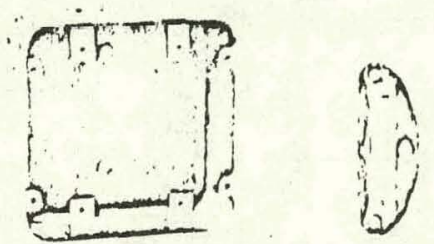

Back box for

combination forms (CR101 X14)
Locking atlachment for standard

starlers (C $1101 \times 3$ )

\section{ORDERING INFORMATION}

\begin{tabular}{|c|c|c|c|c|c|}
\hline \multirow{3}{*}{$\begin{array}{l}\text { Catalog } \\
\text { Number } \\
\text { Component } \\
\text { Only }\end{array}$} & \multirow[b]{2}{*}{ STARTER COMPONENTS } & \multicolumn{2}{|c|}{ Toggle Operated } & \multicolumn{2}{|c|}{ Key Operated } \\
\hline & & $\begin{array}{l}1 \text { Pole } \\
\text { Switch }\end{array}$ & $\begin{array}{l}2 \text { Pole } \\
\text { Switch }\end{array}$ & $\begin{array}{l}1 \text { Pole } \\
\text { Switcli }\end{array}$ & $\begin{array}{l}2 \text { Pole } \\
\text { Switch }\end{array}$ \\
\hline & Description & \multicolumn{4}{|c|}{ Catalog Number-includes complete switch plus component } \\
\hline CR101 X1 & Flush plate with $115 / 230$ volt indicating light and screws & CR101 Y31 & CRIO1 H31 & $\begin{array}{l}\text { CR101 Y310K } \\
\text { CR10I Y300K }\end{array}$ & $\begin{array}{l}\text { CR101 H310K } \\
\text { CR101 H30OK }\end{array}$ \\
\hline CRIO1 $\times 3$ & $\begin{array}{l}\text { Standard flush plate with screws } \\
\text { Locking attachment (lock not included) }\end{array}$ & $\ldots \ldots$ & $\ldots \ldots$ & $\ldots \ldots \ldots$ & $\ldots \ldots \ldots . . . .$. \\
\hline CRIOI $\times 4$ & Cover (front) with $115 / 230$ volt neon indicating light and screws & $\ldots \ldots \ldots$ & $\ldots \ldots$ & $\ldots \ldots \ldots$ & $\ldots \ldots \ldots$ \\
\hline CR101 X5 & Standard cover (front) with screws & $\ldots \ldots$ & $\ldots \ldots \ldots$ & $\ldots \ldots \ldots$ & $\cdots \cdots \cdots \cdots$ \\
\hline CRIO & Stainless-steel flush plate with $115 / 230$ volt indicating light & CRiOi Y51 & CRioi H5i & CRIOI YंडiOK & CRIOL HSIOK \\
\hline $\begin{array}{l}\text { CR } 101 \times 8 \\
\text { CR } 101 \times 10 \\
\text { CR } 101 \times 11\end{array}$ & $\begin{array}{l}\text { Stainless-steel flush plate with screws } \\
\text { Combination flush plate with HOA selector switch } \\
\text { Combination flush plate with HOA selector switch and } 115 / 230 \\
\text { volt neon indicating light }\end{array}$ & $\begin{array}{l}\text { CR } 101 \\
\text { CR } 101 \\
\text { CR } 32 \\
\text { CR } 101 \\
\text { Y35 }\end{array}$ & $\begin{array}{ll}\text { CR101 } & H 5 \\
\text { CR } 101 & H 32 \\
\text { CH101 } & \text { H35 }\end{array}$ & $\begin{array}{l}\text { CR } 101 \text { Y500K } \\
\text { CR1OI Y32OK } \\
\text { CR101 Y350K }\end{array}$ & $\begin{array}{l}\text { CRIOI H50OK } \\
\text { CRIOI H320K } \\
\text { CRIOI H35OK }\end{array}$ \\
\hline $\begin{array}{l}\text { CR101 X12 } \\
\text { CR101 X13 }\end{array}$ & $\begin{array}{l}\text { Combination flush plate for } 2-C R 101 \text { open starters } \\
\text { Combination flush plate for } 2 \text {-CR } 101 \text { open starters with } \\
2-115 / 230 \text { volt neon indicating lights }\end{array}$ & $\begin{array}{l}\text { CR101 Y33 } \\
\text { CR101 Y36 }\end{array}$ & $\begin{array}{ll}\text { CR101 H33 } \\
\text { CR101 H36 }\end{array}$ & $\begin{array}{l}\text { CR101 Y330K } \\
\text { CR101 Y36OK }\end{array}$ & $\begin{array}{l}\text { CR101 H330K } \\
\text { CR101 H360K }\end{array}$ \\
\hline CR $101 \times 14$ & $\begin{array}{l}\text { Box (back) for combination forms } \\
\text { Flush plate with } 115 / 230 \text { volt indicating light, screws and }\end{array}$ & CRioi Y38 & CRiOi H38 & $\cdots$ & \\
\hline & locking attachment (lock not included) & & & & \\
\hline CR101 $\times 2 \& \times 3$ & $\begin{array}{l}\text { Standard flush plate with screws and locking attachment } \\
\text { (lock not included) }\end{array}$ & CR101 i37 & CR101 H37 & & \\
\hline
\end{tabular}




\section{ORDERING INFORMATION - Components (Cont'd) \\ FIELD ASSEMBLY}

Customer assembly of components/open starters can be accomplished by using the table at right as a guide. The assembled units are Type 1 enclosed forms and listed by Underwriters' Laboratories.

\begin{tabular}{|c|c|c|c|}
\hline \multicolumn{2}{|c|}{ COMPONENTS } & $A D D$ & ASSEMBLED UN!T \\
\hline \multicolumn{2}{|c|}{ Component Kit } & \multirow{2}{*}{$\begin{array}{l}\text { Open Starter } \\
\text { Catalog. No. }\end{array}$} & \multirow{2}{*}{$\begin{array}{c}\text { NEMA } 1 \text { Enclosed } \\
\text { Starter } \\
\text { Catalos: No. }\end{array}$} \\
\hline $\begin{array}{l}\text { Encl. Cover } \\
\text { Catalog No. } \\
\end{array}$ & $\begin{array}{c}\text { Encl. Back Box } \\
\text { Catalog No. }\end{array}$ & & \\
\hline $\begin{array}{l}\text { CR101 } \times 5 \\
\text { CR101 X4 } \\
\text { CR101 X5 } \\
\text { CR101 X4 }\end{array}$ & $\begin{array}{l}\text { CR101 X6 } \\
\text { CR101 X6 } \\
\text { CR101 X6 } \\
\text { CR101 X6 }\end{array}$ & $\begin{array}{l}\text { CR101 Y } \\
\text { CR101 Y } \\
\text { CR101 H } \\
\text { CR101 H }\end{array}$ & 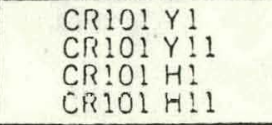 \\
\hline
\end{tabular}

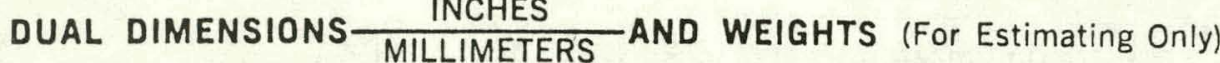

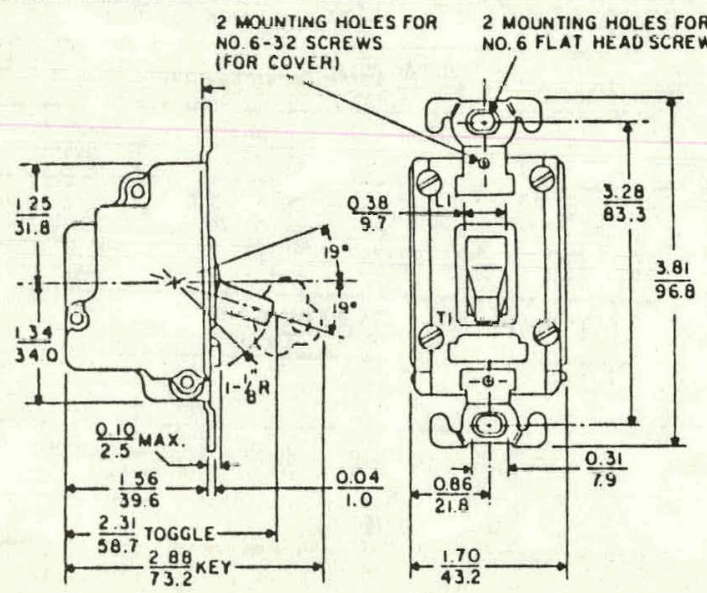

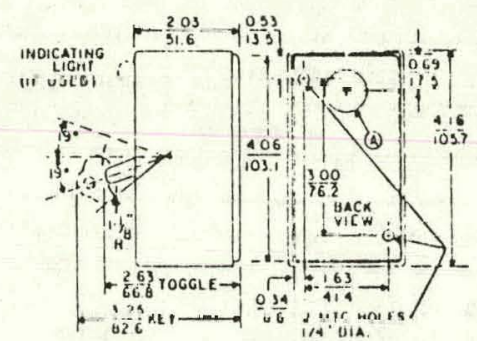

CRIOIH or $Y$ open

starter

shipping wt, $1 \mathrm{lb}$

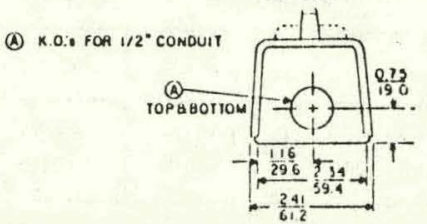

CRIOIHI, HII or YI yHemul puipoto

Approx.

shipping wt, 2 lb
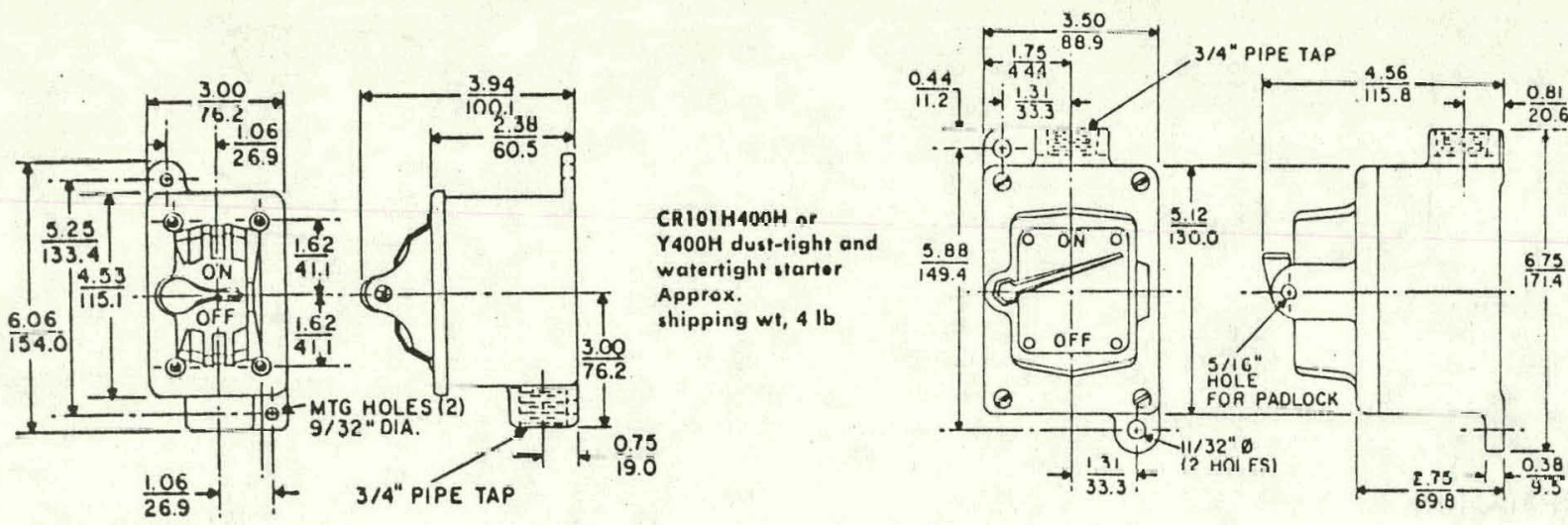

CR101H70OH or

$\mathrm{Y} 400 \mathrm{H}$ dust-tight and watertight starter Approx. shipping wt, $4 \mathrm{It}$
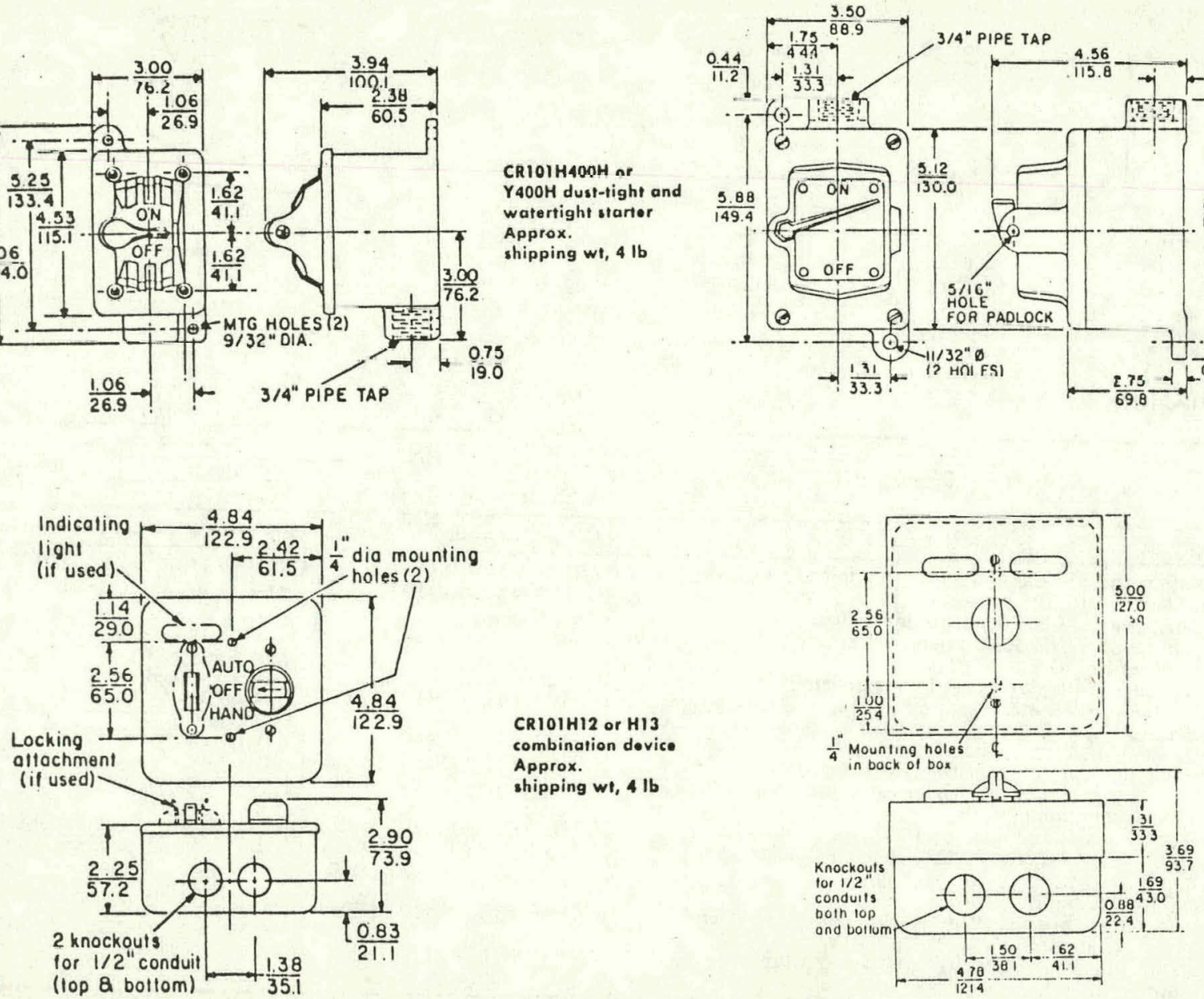

TOOOH heruiduo

location starter

Approx.

shipping w1, $31 / 2 \mathrm{lb}$

CR101H or CRIOIY two-spoed NEMA Typo I enclosed starter

Approx.

shipping $w t, 3 / b$ 


\section{CR101 manual motor stantwe swithin}

The CR101 Types B and J manual motor-starting switches are designed for use with self-protected single and polyphase motors, dc motors, and on-off applications where overload protection is not required.

Typical applications include light machine tools, home workshop equipment, fan motors, pumps or light commercial use.

- Durable Construction - heavy phenolic housing protects switch mechanism

- Long life - contacts of low-resistance silver

- Convenient Mounting - mounting screws have same spacing as wall boxes

- Mechanical Interlock-on three-button reversing and 2-speed forms, prevents two buttons from operating simultaneously

- Flush START and extended STOP button helps pievenl dicidental start and permits quick stop in an emergency

\section{SINGLE-SPEED FORMS}

\begin{tabular}{|c|c|c|c|}
\hline \multicolumn{4}{|c|}{ ORDERING INFORMATION: (Device Catalog Number) } \\
\hline Two-Pole & Three-Pole & Enclosure & $\begin{array}{c}\text { Push Button } \\
\text { Markings }\end{array}$ \\
\hline CRIOI JAOA & CR101 BAOA & $\begin{array}{l}\text { Open with } \\
\text { flush plate }\end{array}$ & START-STOP \\
\hline CR101 JA1A & CR101 BA1A & NEMA Type 1 & START-STOP \\
\hline CRIO1 JAOB & CR101 BAOB & $\begin{array}{l}\text { Open with } \\
\text { flush plate }\end{array}$ & ON-OFF \\
\hline CR101 JA1B & CR101 BA1B & NEMA Type 1 & ON-OFF \\
\hline
\end{tabular}

\section{2-SPEED AND REVERSING FORMS}

\begin{tabular}{|c|c|c|}
\hline Three-Pole & Enclosure & $\begin{array}{l}\text { Push Button } \\
\text { Markings }\end{array}$ \\
\hline CR101 BBOB & $\begin{array}{l}\text { Open with } \\
\text { flush plate }\end{array}$ & FAST-STOP-SLOW \\
\hline CR101 BB1B & NEMA Type 1 & FAST-STOP-SLOW \\
\hline CR101 BEOA & $\begin{array}{l}\text { Open with } \\
\text { flush plate }\end{array}$ & FORWARD-OFF-REVERSE \\
\hline CR101 BE1A & NEMA Type 1 & FORWARD-OFF-REVERSE \\
\hline CR101 BEOB & $\begin{array}{l}\text { Open with } \\
\text { flush plate }\end{array}$ & FORWARD-STOP-REVERSE \\
\hline CR101 BE1B & NEMA Type 1 & FORWARD-STOP-REVERSE \\
\hline CR101 BEOC & $\begin{array}{l}\text { Open with } \\
\text { flush plate }\end{array}$ & UP-STOP-DOWN \\
\hline CR101 BE1C & NEMA Type 1 & UP-STOP-DOWN \\
\hline
\end{tabular}

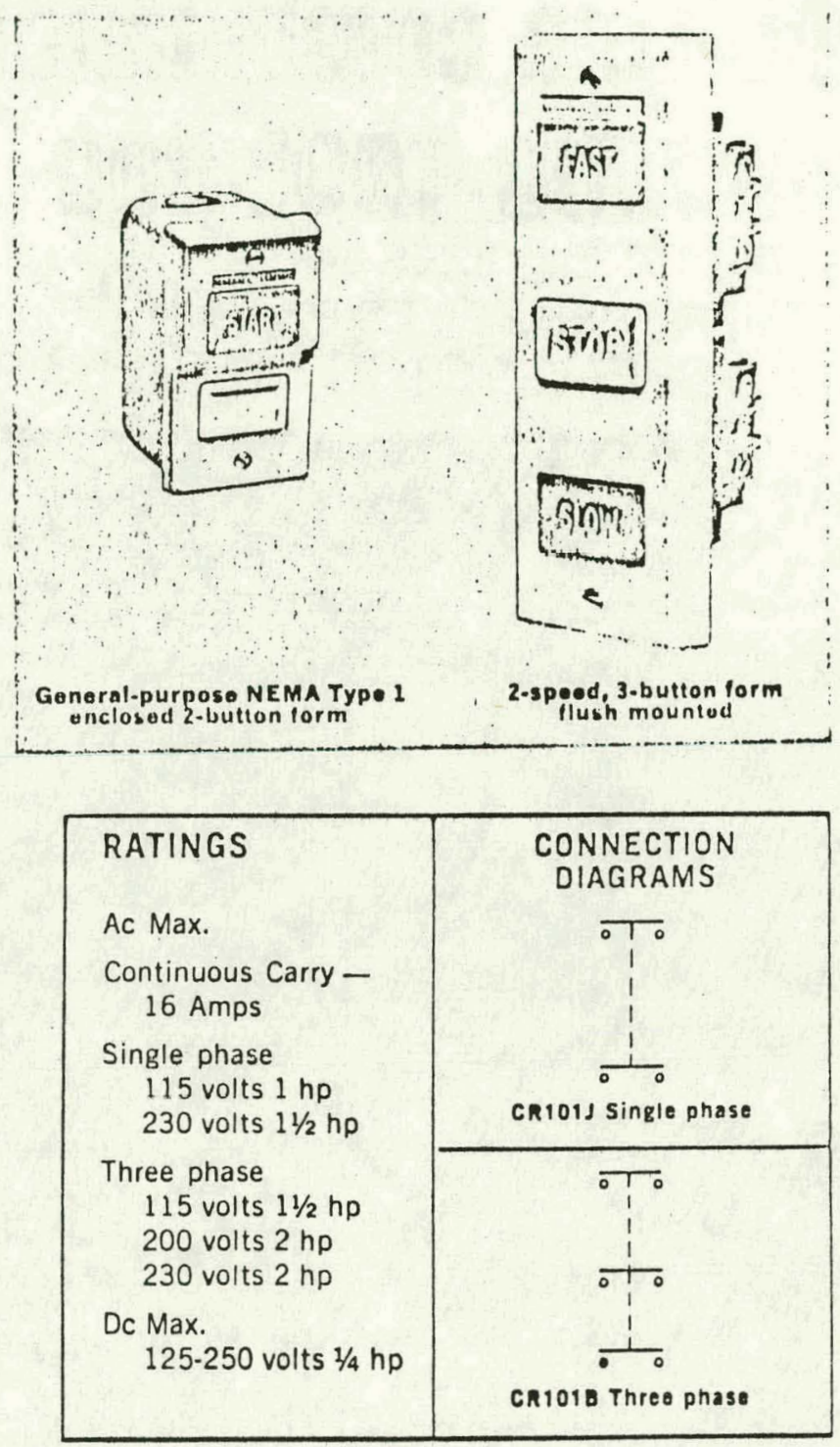

P

\section{RATINGS}

Ac Max.

Three phase

115 volts $11 / 2 \mathrm{hp}$ 200 volts $2 \mathrm{hp}$ 230 volts 2 hp

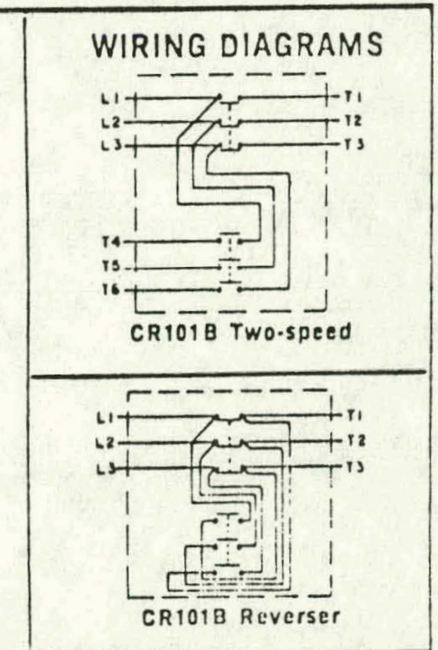




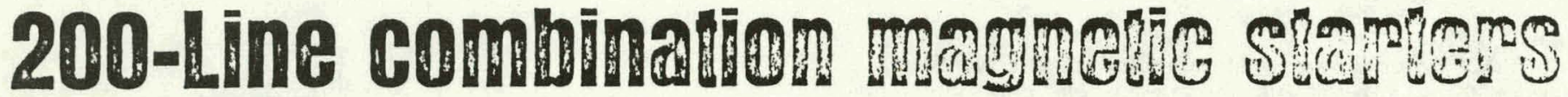 and MOD-TMOL 200}

- NEMA TYPE 1 SIZES 0-5

- NEMA TYPE 12 SIZES 0-5

- MAG BREAK MOTOR STARTERS

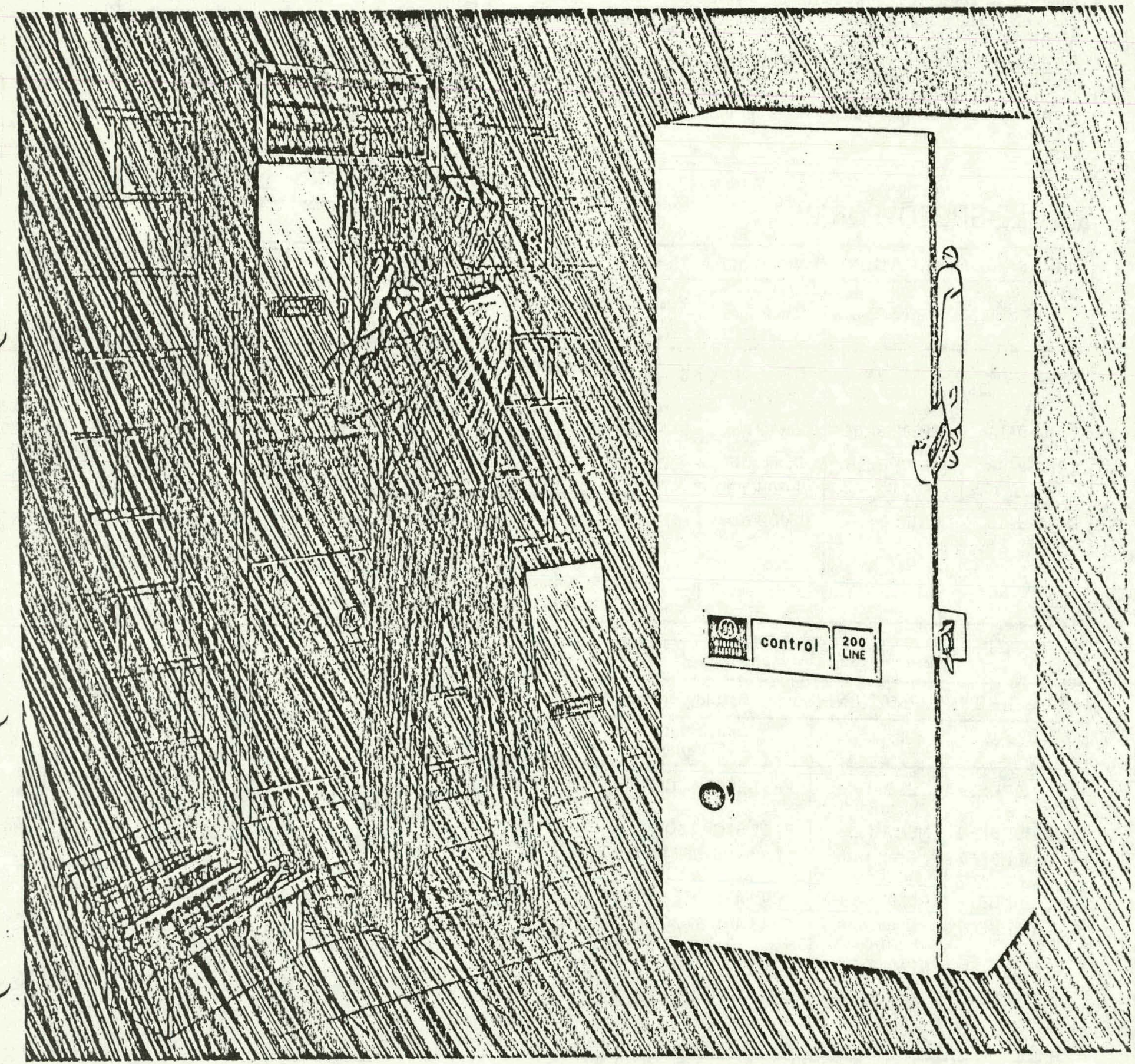


CR207-DOOR CLOSED

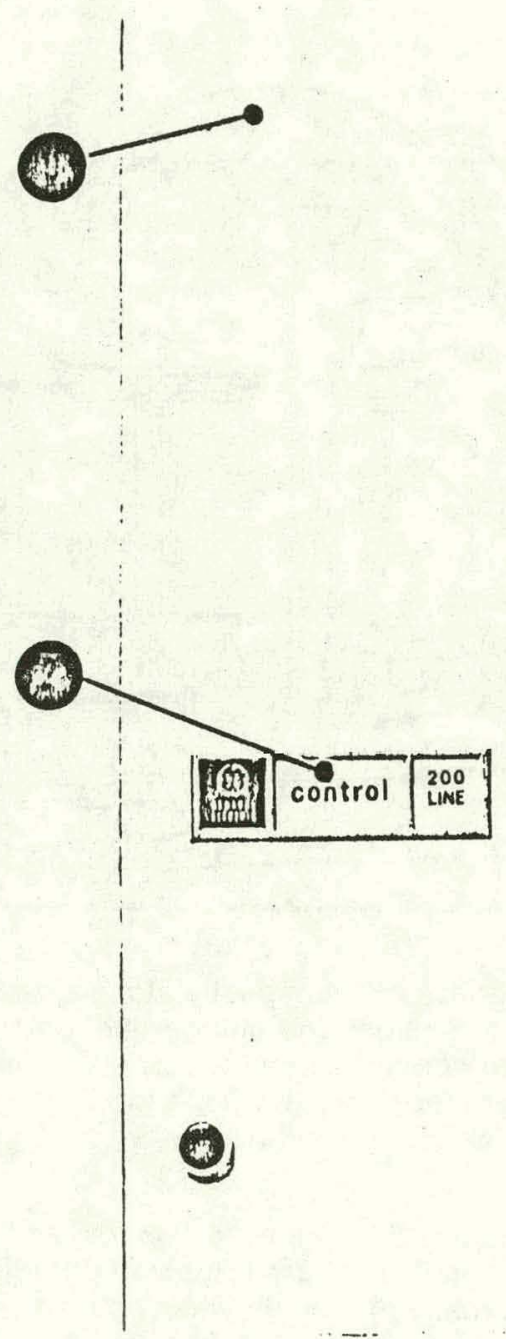

The 200-Line combination magnetic starter, like each of the members of General Electric's smart looking 200-Line family, was designed with features that make it the industry's most contemporary starter package. The 200-LineGE's "second generation" of magnetic motor starters-consolidates the time proved dependability of the 100-Line with the most recent developments in control technology. Yet, basic renewal parts and overload relay heaters are completely interchangeable from line to line.
CR207-INSIDE OF DOOR CR207-COMPONENT PARTS

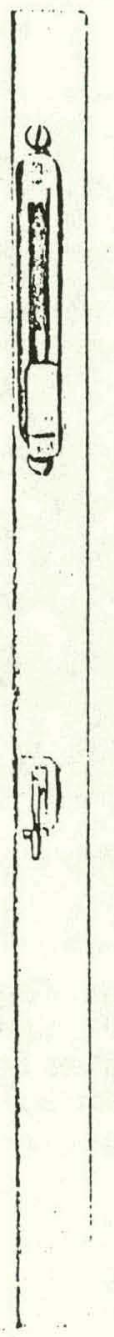

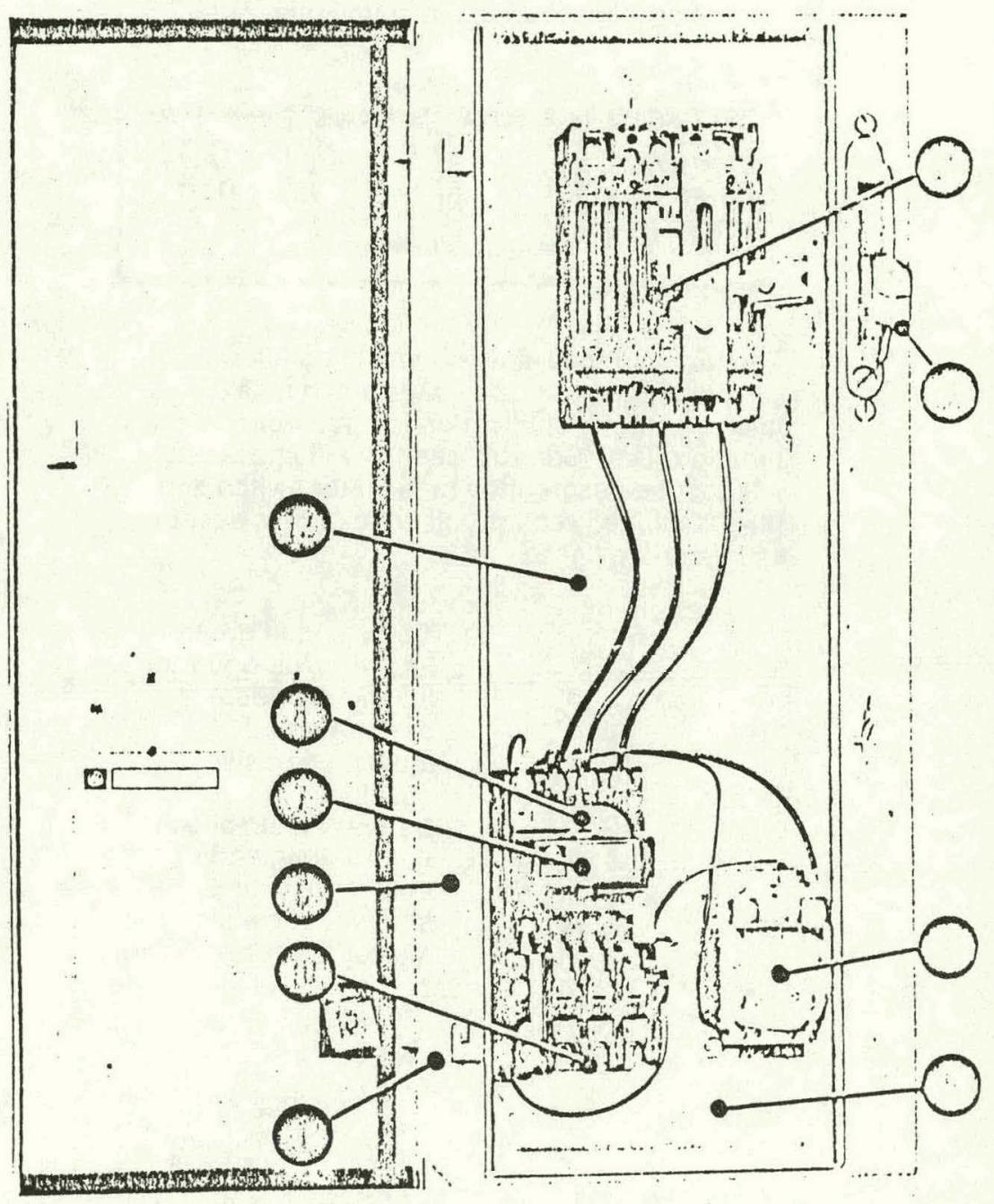

Both inside and out the combination magnetic starter is every inch a member of the 200-Line family. Its modern design makes it easy to install and wire. The starter's vertical contact design makes possible convenient inspection and maintenance. All mechanlcal parts are built to perform with greater motor protection and assured safety. And this quality apparatus provides the utmost in combination starter flexibility. 
1. Removable hinged enclosure cover allow's for optional side-by-side butt mounting and simplifies inspection and maintenance.

2.

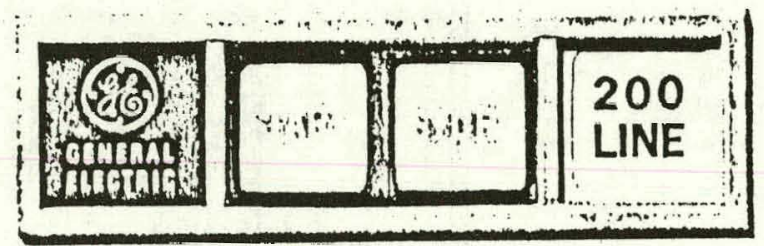

The dual purpose slotted nameplate allows for installation of custom labels in the fleld, giving instant Identification to circuit or control function. The "Control" section will knock out to accept a push button or selector switch and the "200-LIne" section will knock out to accept an indicating llght.

3.

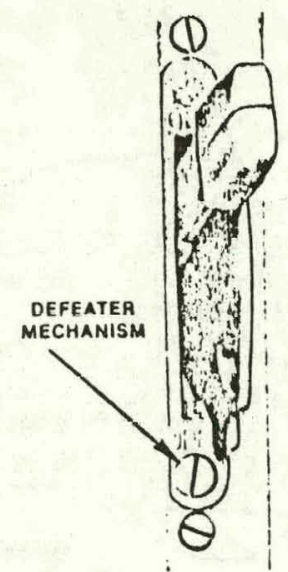

4. Control power transformer is available either factory installed or as a kit for field installatlon. Shortcircuit protection in low-voltage side is standard. Transformer is also available with both primary and secondary fused.
Color-coded green and red side-operator handle provides positive visual indication of switch position.

Defeator mechanism allows opening the enclosure with a screwdriver while starter is in operation.

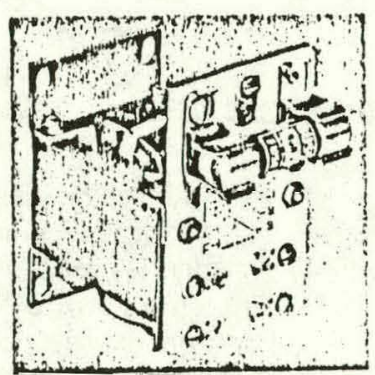

5. Up to 14 knockouts for ample conduit access.

6.

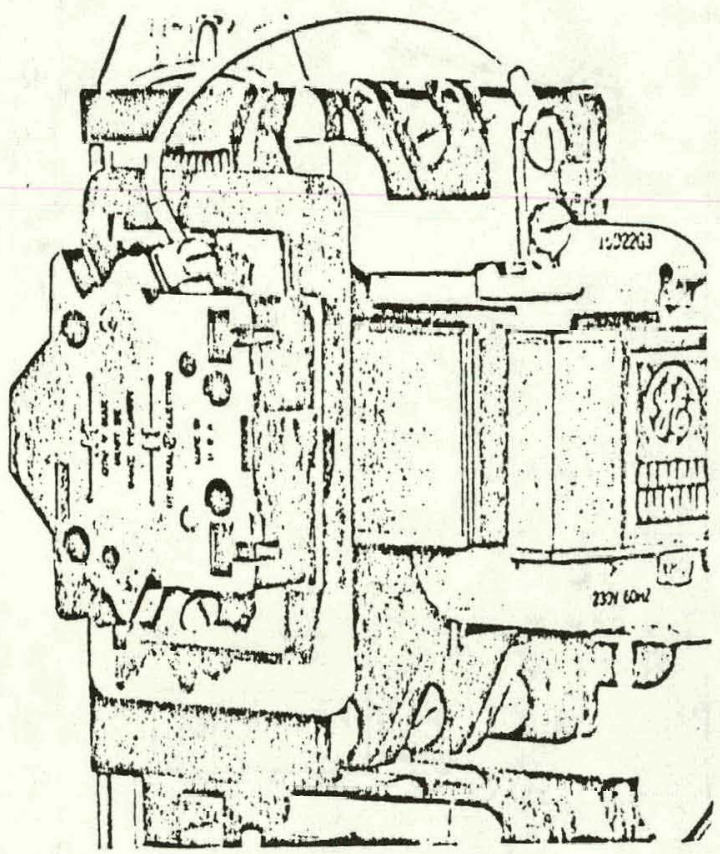

Auxiliary interlocks fit compactly along side the contactor. Straight line plunger motion gives positive contact action. NO or NC contact adder blocks are available for greater application versatility.

7. Specially treated " $E$ " magnet resists rust and corrosion. Magnet faces are protected during idle periods, ready to operate when needed.

8. Encapsulated coil is impervious to molsture ... resists high humidity failure and mechanical damage.

9. Enclosure dimensions are identical for Sizes 0,1 , and 2 . 
10.

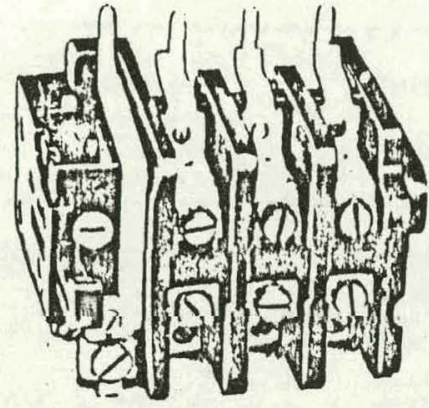

The three-leg block overload relay offers dual bimetal current monitoring... an additional bimetal strip anticipates the rate of temperature rise in the heater, effec-

tively reducing trip time in locked rotor conditions. The manual weld check operator permits you to check for welded contactsin the field, and the overload relay is convertible from manual to automatic reset. Relay trip is adjustable $\pm 10 \%$ of rated value, and a single reset arm resets all three legs at once.

11. Choose from either molded case circuit breaker or fusible QMR disconnect switch.

12. Pre-drilled and tapped holes for field conversion of non-fused and fused forms.

13. Combination starters are designed to mount on General Electric's MOD-TROL 200 framework.

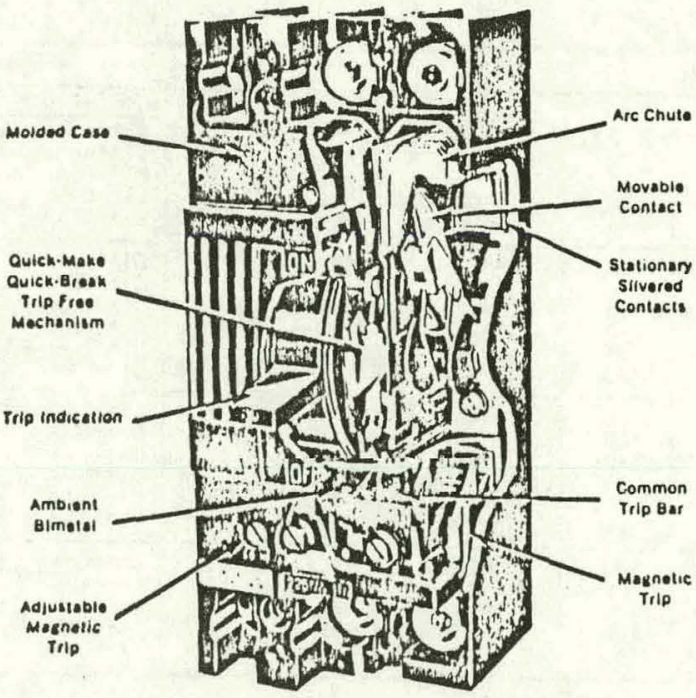

MOLDED CASE CIRCUIT BREAKER

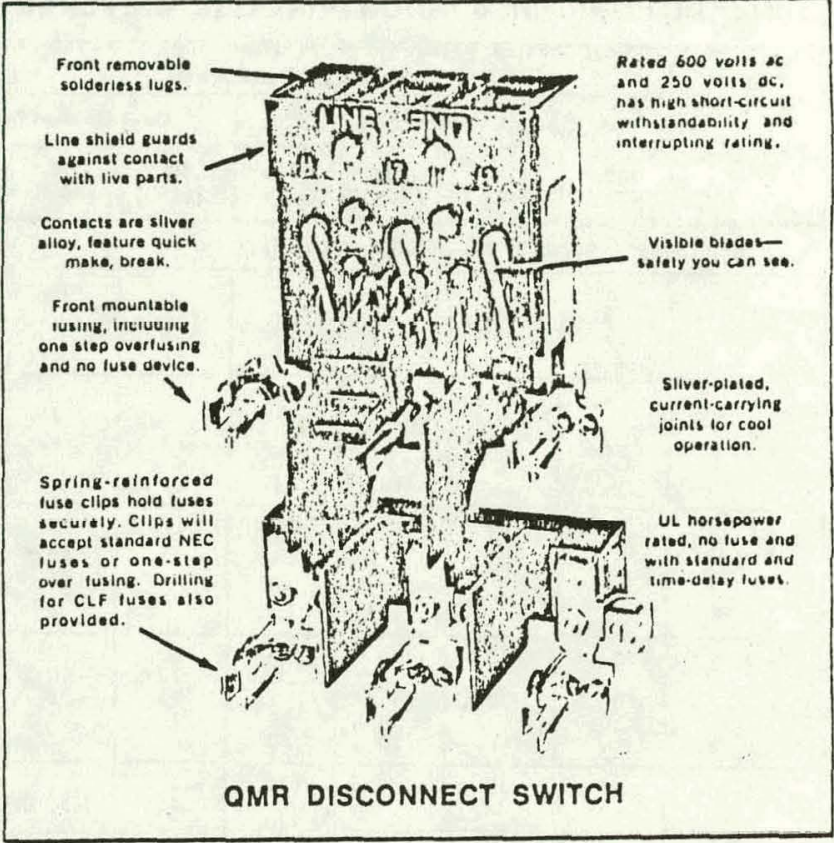

\section{SHORT-CIRCUIT PROTECTION}

Fusible-type combination magnetic starters, sizes 0 through 5 , when equipped with UL labeled, nonrenewable NEC-type fuses having an Interrupting rating not less than the available short-circuit current, are adequate for installation on motor branch circuits where the available short-circuit current at the incoming line terminals of the starter does not exceed 22,000 rms symmetrical amperes. These combination starters can be furnished with noninterchangeable fuse clips for current-limiting fuses and when so equipped may be specified for up to $100,000 \mathrm{rms}$ symmetrical amperes available short circuit current.

Circuit breaker-type combination magnetic starters equipped with the circuit breakers listed in the table below are adequate for installation on mator branch circuits where the available short-circuit current at the incoming line terminals of the starter does not exceed the value shown.

For either type, it is recognized that maintenance of some components may be required after a branch-circult fault and in some cases a device may require replacement.

\begin{tabular}{|c|c|c|c|c|c|}
\hline \multirow{3}{*}{$\begin{array}{l}\text { INEMA } \\
\text { Slan } \\
\text { Slationt }\end{array}$} & \multirow{2}{*}{\multicolumn{2}{|c|}{ Criculf Aruaker }} & \multirow{3}{*}{$\begin{array}{l}\text { Nhox } \\
\text { syslum } \\
\text { vallopi }\end{array}$} & \multirow{2}{*}{\multicolumn{2}{|c|}{ 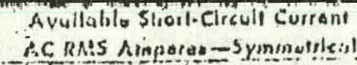 }} \\
\hline & & & & & \\
\hline & ryna: & Max & & $\begin{array}{l}115,200,2,230 \\
\text { volits }\end{array}$ & $\begin{array}{l}46010<00 \\
\text { Volls }\end{array}$ \\
\hline $0,1,2,3$ & $\left\{\begin{array}{l}\text { TEB } \\
\text { TED }\end{array}\right.$ & 100 & $(240$ or $) 600$ & $\begin{array}{l}10,000 \\
1,000\end{array}$ & \\
\hline 3 & TED & 125 & & & $\begin{array}{l}14,000 \\
14,000\end{array}$ \\
\hline 4 & & & & & 22,000 \\
\hline 5 & $\left\{\begin{array}{l}\text { TJX4 } \\
\text { TSK }\end{array}\right.$ & 400 & & 22,000 & 22,000 \\
\hline 5 & TJK6 & 600 & 800 & 22,000 & 22,000 \\
\hline
\end{tabular}




\section{0-LINE MAGNETIC STARTER ordering informeation}

GENERAL PURPOSE \& INDUSTRIAL USE-REVERSING \& NON-REVERSING STARTERS

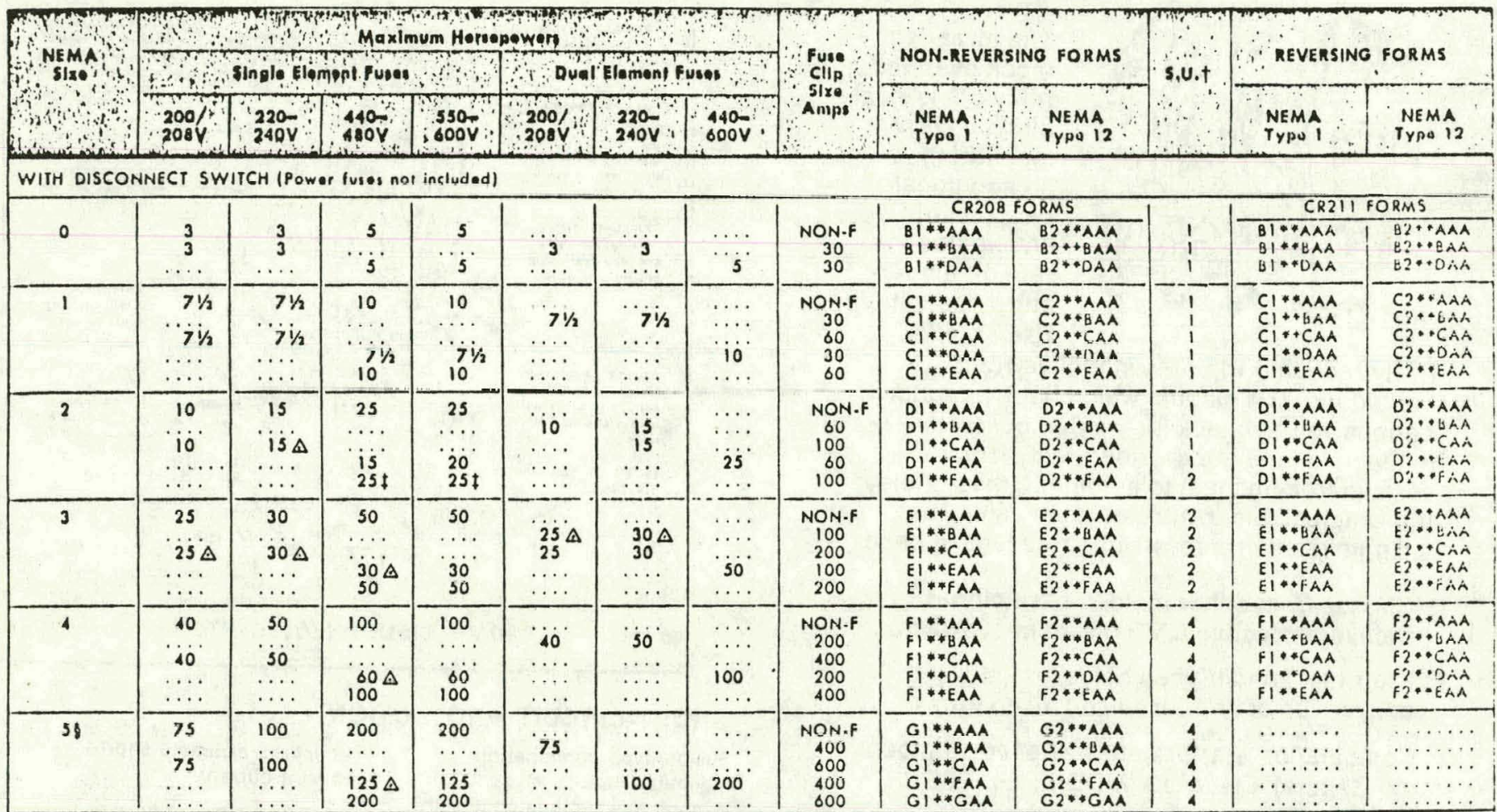

-Coll Suftix Tablo

\begin{tabular}{|c|c|c|c|}
\hline $\begin{array}{l}\text { Prequancy } \\
\text { (Hortz) }\end{array}$ & 1135 & $200 / 20 a \mathrm{~V}$ & $230 \mathrm{~V}$ \\
\hline \multirow[t]{3}{*}{60} & 02 & 23 & 03 \\
\hline & $460 \mathrm{~V}$ & s75V & $600 \mathrm{~V}$ \\
\hline & 04 & 05 & 08 \\
\hline \multirow{4}{*}{$\begin{array}{c}\text { Prequency } \\
\text { (Hertis). } \\
\text { so }\end{array}$} & $110 \mathrm{~V}$ & $220 \mathrm{~V}$ & $380 \mathrm{~V}$ \\
\hline & 07 & 08 & 04 \\
\hline & $440 \mathrm{~V}$ & ssov & $600 \mathrm{~V}$ \\
\hline & 09 & 10 & 11 \\
\hline
\end{tabular}

Use 22 for dual ratod $120 \mathrm{~V}$

$60 \mathrm{~Hz} / 110 \mathrm{~V}, 50 \mathrm{~Hz}$ coll.

t Space unlts for CR207 CA208 when

Inslalled on MOD-TROL Irame.

\$ Roquires overoizo enclesure. Soo Fig. 2

$\Delta$ For ordinary slariing duly only. Dual ole. ment, next larger size luses or breaker with hlghor irip rating is rocommended lor trequent starts of long accolerating

I limo. s nemenclature llising applles to 60 or 50 heris forms only.

NOrE, Packages of 100 plastic insent cards are ovailable for use in the enclosure cover Identification panel. Order CR205X147A.

\begin{tabular}{|c|c|c|c|c|c|c|c|c|c|c|}
\hline \multirow{2}{*}{$\begin{array}{l}\text { NEMA } \\
\text { SIXe }\end{array}$} & \multicolumn{4}{|c|}{ Maximum Horeopowars } & \multirow{2}{*}{$\begin{array}{l}\text { Clircult } \\
\text { Broaker } \\
\text { Ratling } \\
\text { Ampo }\end{array}$} & \multicolumn{2}{|c|}{ NON-REVERSING FORMS } & \multirow{2}{*}{ S.u. } & \multicolumn{2}{|c|}{ REVERSING FORMS } \\
\hline & $\begin{array}{l}200 / \\
200 \mathrm{~V}\end{array}$ & $\begin{array}{l}220 \\
240 Y\end{array}$ & $440-$ & $\begin{array}{l}550- \\
600 \mathrm{~V}\end{array}$ & & TYPA 1 & $\underset{\text { TYPO } 12}{\text { NEMA }}$ & & $\begin{array}{l}\text { NEMA } \\
\text { TYPO I }\end{array}$ & $\begin{array}{l}\text { NEMA } \\
\text { Tyipo i2 }\end{array}$ \\
\hline
\end{tabular}

WITH THERMAL MAGNETIC TRIP BREAKERS

\begin{tabular}{|c|c|c|c|c|c|c|c|c|c|c|}
\hline \multirow[b]{2}{*}{0} & \multirow[b]{2}{*}{$\begin{array}{r}2 \\
3 \\
\cdots \cdots \\
\cdots \cdots \\
\cdots\end{array}$} & \multirow[b]{2}{*}{$\begin{array}{c}2 \\
3 \\
\cdots \cdots \\
\cdots \cdots \\
\cdots \cdots \\
\end{array}$} & \multirow[b]{2}{*}{$\begin{array}{l}\cdots \\
\cdots \\
j \\
\cdots\end{array}$} & \multirow[b]{2}{*}{$\begin{array}{l}\cdots \\
\cdots \\
\cdots \\
5\end{array}$} & \multirow[b]{2}{*}{$\begin{array}{l}15 \\
20 \\
15 \\
20 \\
15\end{array}$} & \multicolumn{2}{|c|}{ CR207 FORMS } & \multirow[b]{2}{*}{$\begin{array}{l}1 \\
1 \\
1 \\
1 \\
1\end{array}$} & \multicolumn{2}{|c|}{ CR210 FORMS } \\
\hline & & & & & & $\begin{array}{l}81 * * A A A \\
81 * * B A A \\
81 * * F A A \\
B 1 * * G A A \\
B 1 * * W A A A\end{array}$ & $\begin{array}{l}B 2 * * A A A \\
82 * * B A A \\
B 2 * * F A A \\
B 2 * * G A A \\
B 2 * * W A A\end{array}$ & & $\begin{array}{l}B 1 \because A A A \\
81 \because B A A \\
B 1 \because F A A \\
\forall 1 \because G A A \\
B 1 \because W A A \\
\end{array}$ & 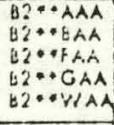 \\
\hline 1 & $\begin{array}{c}\quad 5 \\
71 / 2 \\
\cdots \cdots \\
\cdots \cdots \\
\cdots \cdots\end{array}$ & $\begin{array}{l}{ }_{71 / 2}^{5} \\
\cdots \cdots \\
\cdots \cdots \\
\cdots \cdots \\
\cdots \cdots\end{array}$ & $\begin{array}{l}\cdots \\
\cdots \\
\cdots \\
10 \\
\ldots \\
\ldots\end{array}$ & $\begin{array}{l}\cdots \\
\cdots \\
71 / 2 \\
\cdots \\
i 0\end{array}$ & $\begin{array}{l}40 \\
50 \\
20 \\
30 \\
35 \\
30\end{array}$ & $\begin{array}{l}\text { CI **DAAA } \\
\text { CI **EAA } \\
\text { CI } * * \text { XAAA } \\
\text { CI } * * \text { HAA } \\
\text { CI **IAA } \\
\text { CI } * * \text { YAA }\end{array}$ & $\begin{array}{l}C 2 * * D A A \\
C 2 * * E A A \\
C 2 * * X A A \\
C 2 * * H A A \\
C 2 * * I A A \\
C 2 * * Y A A\end{array}$ & 1 & 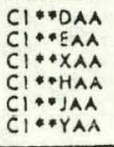 & 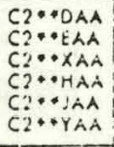 \\
\hline 2 & $\begin{array}{l}10 \\
\cdots \cdots \\
\cdots \cdots \\
\cdots \\
\cdots\end{array}$ & $\begin{array}{l}15 \Delta \\
15 \\
\cdots \cdots \\
\cdots \cdots \\
\cdots \cdots\end{array}$ & $\begin{array}{l}25 \Delta \Delta \\
25\end{array}$ & $\begin{array}{l}\cdots \\
\text { is } \\
\cdots \\
25\end{array}$ & $\begin{array}{r}50 \\
100 \\
40 \\
50 \\
70 \\
50\end{array}$ & $\begin{array}{l}\text { DI } * * \text { EAA } \\
\text { DI **GAAA } \\
\text { DI**YAA } \\
\text { DI } * * \text { MAAA } \\
\text { DI **NAA } \\
\text { D } 1 * * \text { ZAA }\end{array}$ & $\begin{array}{l}D 2 * * E A A \\
D 2 * * G A A \\
D 2 * * Y A A \\
D 2 * * M A A \\
D 2 * * N A A \\
D 2 * * 2 A A\end{array}$ & 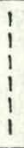 & 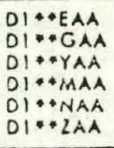 & 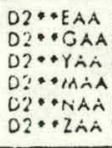 \\
\hline 3 & $\begin{array}{l}25 \\
\cdots \cdots \\
\cdots \cdots\end{array}$ & $\begin{array}{l}30 \triangle \\
30 \\
\cdots \\
\cdots \\
\cdots\end{array}$ & $\begin{array}{l}\cdots \\
\cdots \\
\text { so } \\
\cdots\end{array}$ & $\begin{array}{l}\cdots \\
30 \\
30\end{array}$ & $\begin{array}{r}100 \\
125 \\
70 \\
100 \\
100\end{array}$ & $\begin{array}{l}E 1 * * C A A \\
E 1 * * T A A \\
E 1 * * R A A \\
E 1 * * F A A \\
E 1 * * S A A\end{array}$ & $\begin{array}{l}E 2 * C A A A \\
E 2 * I A A \\
E 2 * * R A A \\
E 2 * * F A A \\
E 2 * S A A\end{array}$ & 2 & $\begin{array}{l}E I \because C C A A \\
F \mid \cdots B B A \\
E I \cdots R A A \\
E I \cdots F A A \\
E I \cdots S A A\end{array}$ & $\begin{array}{l}E 2 * C A A \\
E 2 \because B E A \\
E 2 \because K A A \\
E 2 \because F A A \\
E 2 * S A A\end{array}$ \\
\hline 4 & ${ }_{40}$ & ${ }_{50}^{40} \mathrm{~A}$ & $\begin{array}{r}60 \\
75 \\
100\end{array}$ & $\begin{array}{r}75 \\
100\end{array}$ & $\begin{array}{l}125 \\
150 \\
200\end{array}$ & $\begin{array}{l}F 1 * * B A A \\
F 1 * * C A A \\
F \mid * * E A A\end{array}$ & $\begin{array}{l}F 2 * * B A A \\
F 2 *+C A A \\
F 2 * * E A A\end{array}$ & & $\begin{array}{l}F \mid \because B B A A \\
F \mid * \because C A A \\
F \mid * E E A A\end{array}$ & $\begin{array}{l}F_{2} \because B A A \\
F^{2}, * C A A \\
F_{2} \cdots E A A\end{array}$ \\
\hline $5 \ddagger$ & \%... & $\begin{array}{r}60 \\
75 \\
100 \\
\end{array}$ & $\begin{array}{l}125 \Delta \\
150 \\
200\end{array}$ & $\begin{array}{l}150 \\
200\end{array}$ & $\begin{array}{l}250 \\
300 \\
400\end{array}$ & $\begin{array}{l}\text { G1**AAA } \\
\text { GI**BAA } \\
\text { GI**CAA }\end{array}$ & $\begin{array}{l}G 2 * * A A A \\
G 2 * * B A A \\
G 2 * * C A \Lambda\end{array}$ & & & \\
\hline
\end{tabular}




\section{INDUSTRIAL JIC SAFETY STARTERS-REVERSING \& NON-REVERSING FORMS}

Complles with most automotive industry standards and electrical standards for Mass Production Equipment EMP-1-1967

SAFETY STARTER WITH FUSIBLE DISCONNECT SWITCH

\begin{tabular}{|c|c|c|c|c|c|c|c|c|c|c|}
\hline \multirow{3}{*}{ 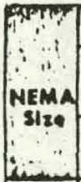 } & \multicolumn{7}{|c|}{ Maximum Horsopowar } & \multirow{3}{*}{$\begin{array}{l}\text { Fuse } \\
\text { Clip } \\
\text { Sixo } \\
\text { Amps }\end{array}$} & \multirow{2}{*}{\multicolumn{2}{|c|}{$\begin{array}{l}\text { Nomenclaturo } \\
\text { (Includes Standord Raled } \\
\text { Control Clirculi Transformor) }\end{array}$}} \\
\hline & \multicolumn{4}{|c|}{ Single Eloment Fupes } & \multicolumn{3}{|c|}{ Dual Eloment Fuses } & & & \\
\hline & $\begin{array}{l}200 / \\
2004\end{array}$ & $\begin{array}{l}2200^{\circ} \\
240 \mathrm{~V}\end{array}$ & & & & & $\begin{array}{l}440 . \\
600 \mathrm{~V}\end{array}$ & & & $\begin{array}{c}\text { Rev } \\
\text { form }\end{array}$ \\
\hline 1 & $\begin{array}{c}71 / 2 \\
7 i / s \\
\ldots \\
\ldots\end{array}$ & $\begin{array}{l}71 / 2 \\
\cdots \\
\cdots\end{array}$ & $\begin{array}{l}10 \\
\ldots \\
7 y / 2 \\
10\end{array}$ & $\begin{array}{l}10 \\
\ldots \\
71 / 2 \\
10\end{array}$ & $71 / 2$ & $71 / 2$ & 10 & $\begin{array}{c}\text { NON.F } \\
30 \\
60 \\
30 \\
60\end{array}$ & & \\
\hline 2 & $\begin{array}{c}10 \\
10 \\
\ldots \\
\ldots\end{array}$ & $\begin{array}{l}\text { ISA } \\
\ldots \\
\ldots\end{array}$ & $\begin{array}{l}25 \\
\cdots \\
15 \\
25\end{array}$ & $\begin{array}{l}25 \\
\ldots \\
20 \\
25\end{array}$ & $\begin{array}{l}10 \\
\cdots \\
\cdots\end{array}$ & $\begin{array}{l}15 \Delta \\
15\end{array}$ & $\begin{array}{l}\ldots \\
\ldots \\
25 \\
\ldots\end{array}$ & $\begin{array}{c}\text { NON.F } \\
60 \\
100 \\
60 \\
100\end{array}$ & & \\
\hline $\mathrm{J}$ & $\begin{array}{l}25 \\
25 \Delta A\end{array}$ & $\begin{array}{l}30 \\
30 \mathrm{~A}\end{array}$ & so & $\begin{array}{l}50 \\
30 \\
50\end{array}$ & 25 & 30 & 50 & $\begin{array}{l}\text { NON.F } \\
200 \\
100 \\
200 \\
\end{array}$ & & \\
\hline 4 & $\begin{array}{l}40 \\
40 \\
\cdots \\
\cdots\end{array}$ & so & $\begin{array}{c}100 \\
\cdots \\
100 \\
100\end{array}$ & $\begin{array}{c}100 \\
\ldots . \\
100 \\
100\end{array}$ & $\begin{array}{ll}40 \\
\cdots \\
\cdots\end{array}$ & $\begin{array}{ll}\ldots 0 \\
\cdots\end{array}$ & $\ldots$ & \begin{tabular}{|l} 
NON.F \\
200 \\
400 \\
200 \\
400
\end{tabular} & 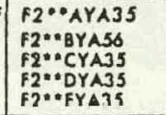 & $\begin{array}{l}F 2 \cdots \text { OAYA2 } \\
F 2 \cdots \text { BYA2 } \\
F 2 \cdots \text { CYA3 } \\
F 2 \cdots \text { DYA2 } \\
\text { F2" EYA2 }\end{array}$ \\
\hline
\end{tabular}

REVERSING NON-REVERSING TYPE 12 STARTERS-JIC Complles with electrlcal standards for General Purpose Machine Tools, EGP-1-1967

TYPE 12 STARTER-JIC WITH DISCONNECT SWITCH

\begin{tabular}{|c|c|c|c|c|c|c|c|c|c|c|}
\hline \multirow{3}{*}{ 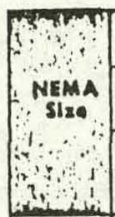 } & \multicolumn{7}{|c|}{$\therefore$ Max. Horsopowor } & \multirow{3}{*}{$\begin{array}{l}\text { Fuso } \\
\text { Clip } \\
\text { Sisto } \\
\text { Ampo }\end{array}$} & \multirow{2}{*}{\multicolumn{2}{|c|}{$\begin{array}{l}\text { Whith control lransformer } \\
230 / 460 \text {-voll supply, } 11 \text {; } \\
\text { voll sonirol, } 60 \mathrm{~Hz}\end{array}$}} \\
\hline & \multicolumn{4}{|c|}{ Singlo Element } & \multicolumn{3}{|c|}{$\therefore$ Dual Elomont } & & & \\
\hline & $\begin{array}{l}200 / \\
2008 \mathrm{~V}\end{array}$ & & $4400^{\circ}$ & $\begin{array}{l}550 . \\
600 \mathrm{~V}\end{array}$ & $\begin{array}{l}200 / \\
208 \mathrm{~V}\end{array}$ & $\begin{array}{l}2200^{\circ} \\
240 \mathrm{~V}\end{array}$ & $\begin{array}{l}440 . \\
600 \mathrm{~V}\end{array}$ & & & \\
\hline 0 & 3 & $\begin{array}{l}3 \\
3\end{array}$ & s & $\stackrel{5}{5}$. & 3 & 3 & $\frac{\cdots}{5}$ & & \multicolumn{2}{|c|}{ U.० NEMA Size I } \\
\hline 1 & $\begin{array}{l}71 / 2 \\
71 / 2 \\
\ldots \\
\ldots\end{array}$ & $\begin{array}{l}71 / 2 \\
71 / 2 \\
\cdots \\
\cdots\end{array}$ & $\begin{array}{c}10 \\
\ldots \\
71 / 2 \\
10\end{array}$ & $\begin{array}{c}10 \\
\cdots \\
71 / 2 \\
10\end{array}$ & $\begin{array}{l}7 \mathrm{i} \mathrm{i}_{2} \\
\cdots \\
\cdots \\
\cdots\end{array}$ & $\begin{array}{l}71 \% \\
\cdots \\
\cdots\end{array}$ & $\begin{array}{l}\cdots \\
\cdots \\
\text { io }\end{array}$ & $\begin{array}{c}\text { NON.F } \\
30 \\
60 \\
20\end{array}$ & & \\
\hline 2 & $\begin{array}{l}10 \\
10 \\
\ldots \\
\ldots\end{array}$ & $\begin{array}{l}15 \\
158 \\
\ldots\end{array}$ & $\begin{array}{l}25 \\
\cdots \\
15 \\
25\end{array}$ & \begin{tabular}{|c|}
25 \\
$\cdots$ \\
20 \\
25 \\
\end{tabular} & $\begin{array}{l}10 \\
\cdots \\
\cdots\end{array}$ & $\begin{array}{l}15 \mathrm{~A} \\
15 \\
\cdots \\
\cdots\end{array}$ & $\begin{array}{l}\cdots \\
25\end{array}$ & $\begin{array}{c}\text { NON.F } \\
60 \\
100 \\
60 \\
100\end{array}$ & & \\
\hline J & $\begin{array}{l}25 \\
25 \Delta\end{array}$ & $\begin{array}{l}30 \\
30 \triangle\end{array}$ & $\begin{array}{l}50 \\
30 \% \\
50\end{array}$ & $\begin{array}{l}50 \\
30 \\
50\end{array}$ & 25 & $\begin{array}{l}30 \\
\cdots \\
\cdots\end{array}$ & $\begin{array}{l}50 \\
\ldots \\
\ldots\end{array}$ & $\begin{array}{l}\text { NON-F } \\
200 \\
100 \\
200\end{array}$ & & \\
\hline 4 & $\begin{array}{l}40 \\
40\end{array}$ & $\begin{array}{l}50 \\
50 \\
\ldots\end{array}$ & $\begin{array}{l}.00 \\
800 \\
100\end{array}$ & $\begin{array}{l}100 \\
30 \\
100\end{array}$ & $\begin{array}{l}\cdots \\
\cdots \\
\cdots\end{array}$ & $\begin{array}{l}50 \\
\cdots \\
\cdots\end{array}$ & 100 & $\begin{array}{l}\text { NON.F } \\
400 \\
200 \\
400\end{array}$ & & \\
\hline 58 & $\begin{array}{c}75 \\
75 \\
\ldots\end{array}$ & $\begin{array}{l}100 \\
100\end{array}$ & $\begin{array}{l}200 \\
125 \dot{120} \\
200\end{array}$ & & & $\begin{array}{l}\cdots \\
\cdots \\
\cdots\end{array}$ & 200 & $\begin{array}{l}\text { NON.F } \\
600 \\
400 \\
600\end{array}$ & & $\cdots$ \\
\hline
\end{tabular}

$\Delta$ For ordinary starting duty only. Dual element, nexl larger size fuse or breaker with higher trip 5 Size 3 nomenclature shown applies to 60 . and 50 . Hertz forms only. The transformer is supplied as a conirol relay and transformer for the relay.
SAFETY STARTER WITH CIRCUIT BREAKER

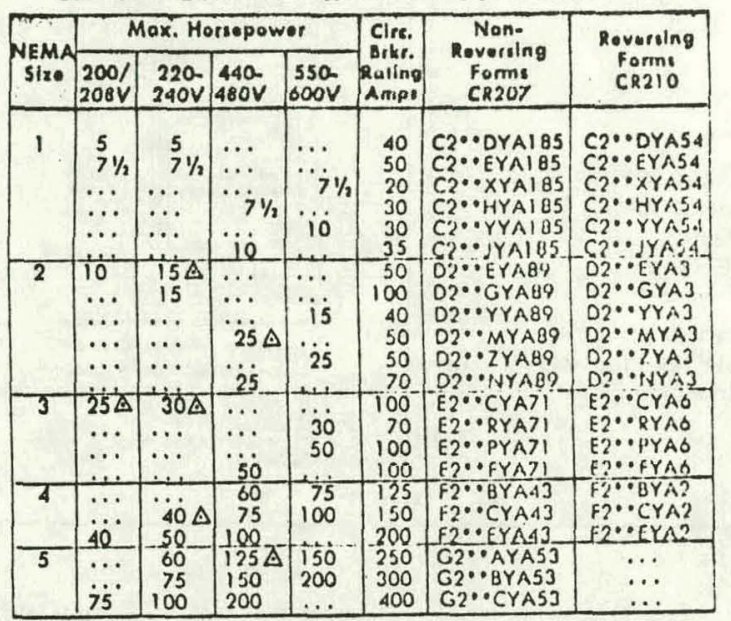

TRANSFORMER/COIL-SUFFIX TABLES

- (Uso where double asterlste appears in nomenclature)

\begin{tabular}{|c|c|c|c|c|c|}
\hline $\begin{array}{c}\text { Voliages, } \\
\text { Supply: } \\
\text { conirol }\end{array}$ & \multicolumn{6}{|c|}{ NEMA SIZE } \\
\cline { 2 - 6 } & 10 & 20 & 30 & 4 & 5 \\
\hline $230-115$ & 03 & 03 & 03 & 03 & 03 \\
240.120 & 58 & 41 & 31 & 37 & 28 \\
460.115 & 04 & 04 & 04 & 04 & 04 \\
480.120 & 57 & 45 & 32 & 36 & 12 \\
575.115 & 05 & 05 & 05 & 05 & 05 \\
600.120 & 13 & 13 & 13 & 13 & 38 \\
\hline
\end{tabular}

- For extra capacity Iransformer, refer to nearest GE Soles Office. TYPE 12 STARTER-JIC WITH THERMAL MAGNETIC TRIP BREAKER \& CONTROL TRANSFORMER

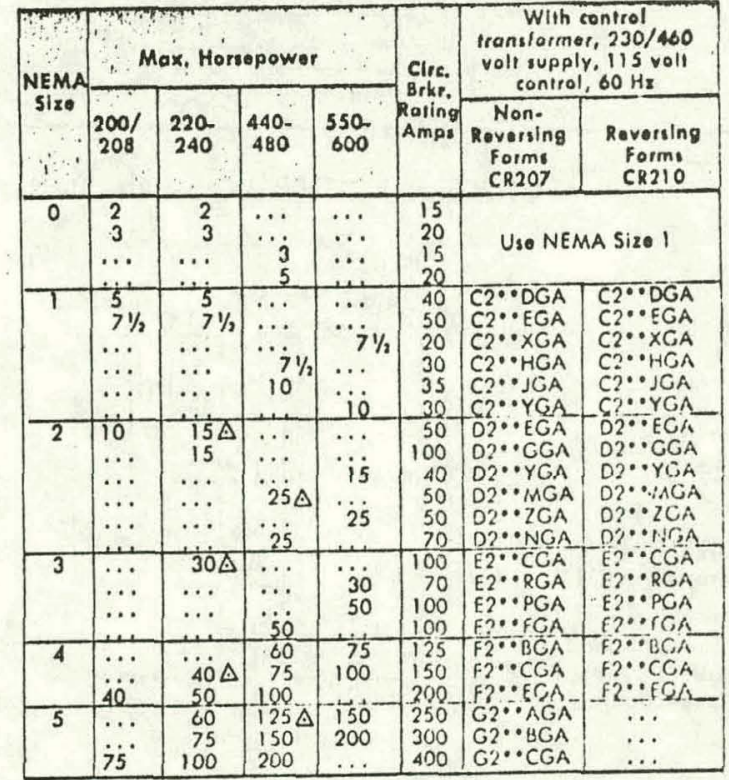

NOTE: For NEMA Typo 12 Multispeed Forms refor to neorest Genero Electric Sales Office. 


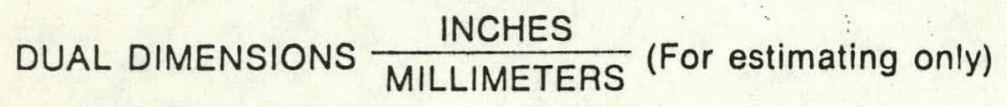

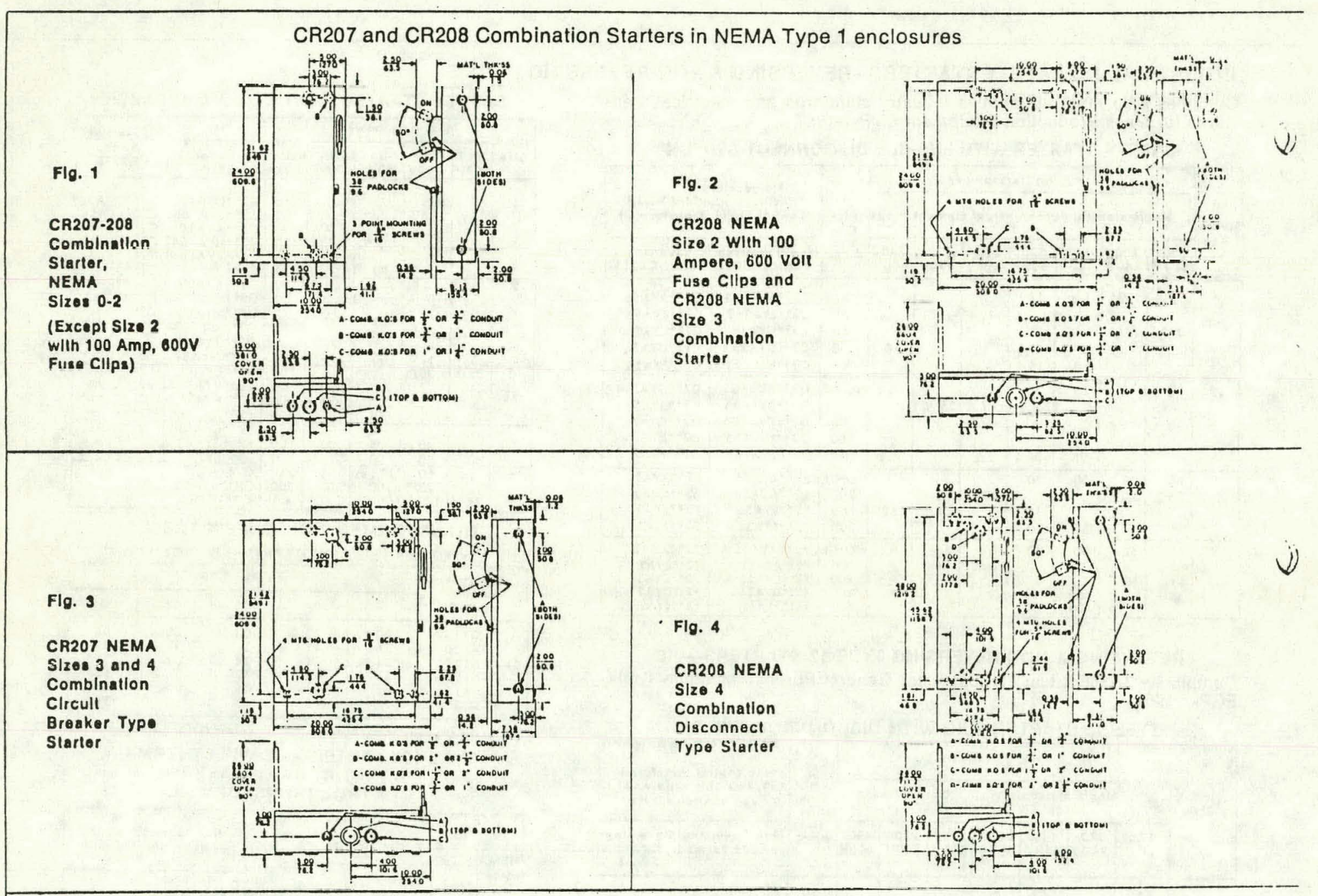

CR207 and CR208 JIC Safety Starters In NEMA Type 12 enclosures

FIg. 5

CR207-208 Safely Starter, NEMA

Sizes 0 -2

(Except Slae 2

with 100 Amp, 600V Fuse Cllps)

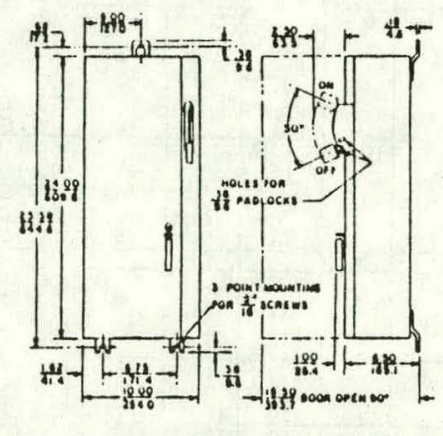




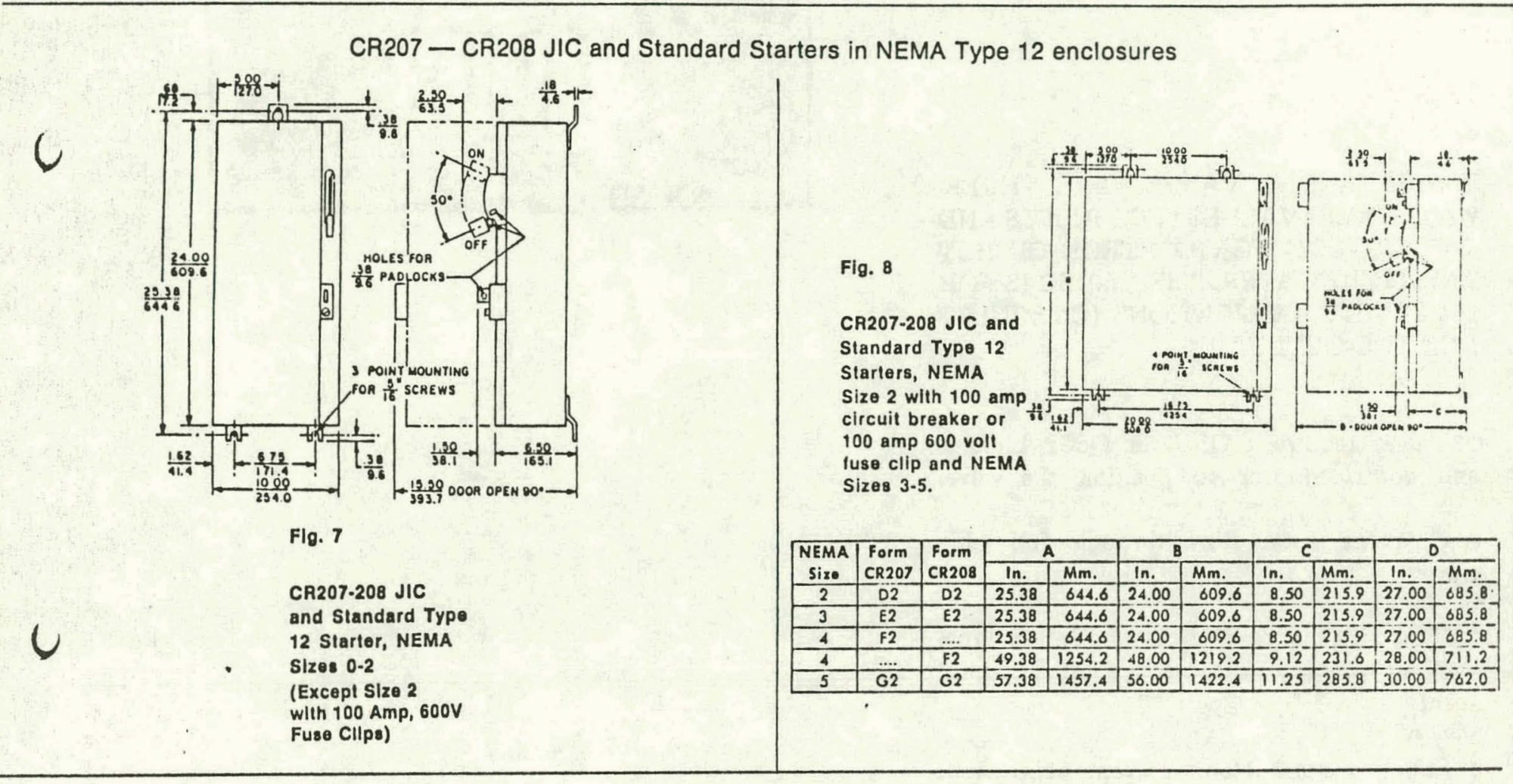

CR210 and CR211 Comblnation Reversing or Multispeed Starters in NEMA Type 12 enclosures

Fig. 0

CA210-211

Reversing of

Mullispeed Safoty

Starters
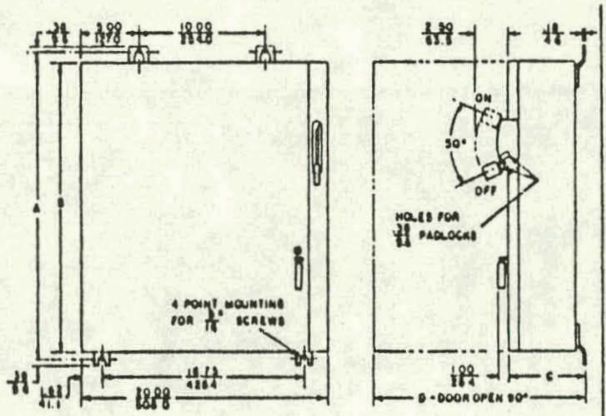

Fig. 10

CR210-211 Type 12
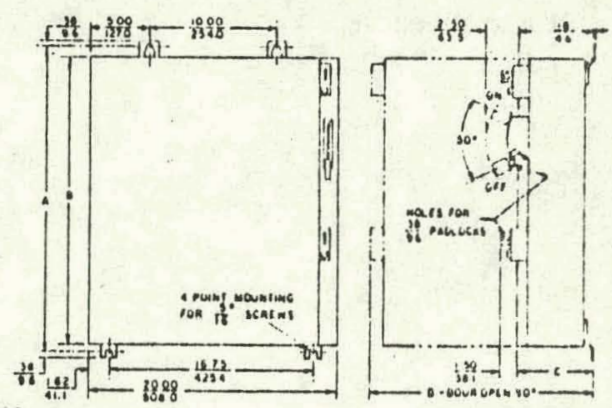

and JIC

Reversing or

Multispead Starter

\begin{tabular}{|c|c|c|c|c|c|c|c|c|}
\hline \multirow{2}{*}{$\begin{array}{c}\text { NEMA } \\
\text { Sixo }\end{array}$} & \multicolumn{2}{|c|}{ A } & \multicolumn{2}{|c|}{$B$} & \multicolumn{2}{|c|}{ C } & \multicolumn{2}{|c|}{ D } \\
\hline & In. & $\mathrm{Mm}$. & In. & $\mathrm{Mm}$. & In. & $\mathrm{Mm}$. & In. & $\mathrm{Mm}$. \\
\hline 0.2 & 25.38 & 644.6 & 24.00 & 609.6 & 8.50 & 215.9 & 27.00 & 685.8 \\
\hline 3,4 & 49.38 & 1254.2 & 48.00 & 1219.2 & 9.12 & 231.6 & 28.00 & 711.2 \\
\hline
\end{tabular}


V5013A AND B VALVES ARE THREEWAY MIXING VALVES (TWO INLETS AND ONE OUTLET) FOR CONTROL OF HOT AND COLD WATER. THE V5013C IS FOR DIVERTING APPLICATIONS (ONE INLET AND TWO OUTLETS).

- Valves require a $\mathrm{Q} 618$ or $\mathrm{Q601}$ Linkage and control motor to position the valve.

$\square$ Constant total flow through full plug travel.

$\square$ Spring-loaded, self-adjusting, Teflon cone packing provides seal-off for all common agents.

口 Stainless steel stem prevents corrosion.

NOTE: Mixing and diverting valves are not interchangeable.

H.A.

REV. 8-75 (.034)
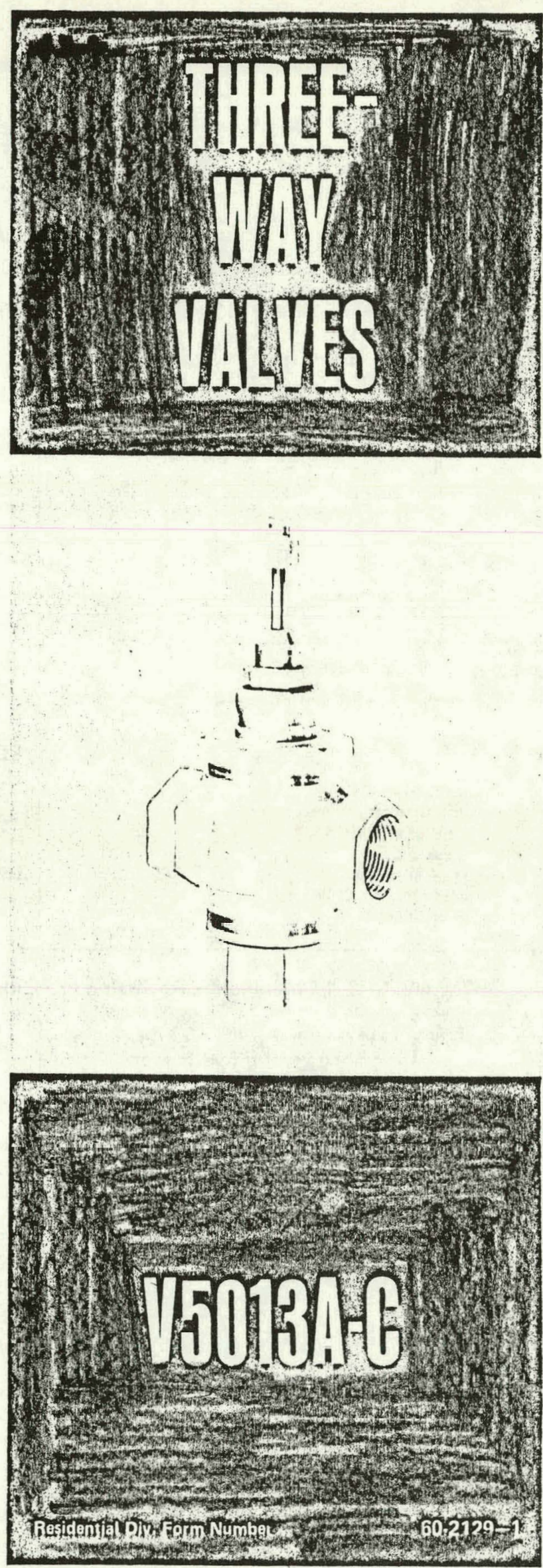
MODELS:

V5013A-Three-Way Mixing Valve with screwed valve end connections.
V5013B-Three-Way Mixing Valve with flanged valve end connections.

V5013C-Three-Way Diverting Valve with flanged valve end connections.

\begin{tabular}{|c|c|c|c|c|c|c|c|c|c|c|c|}
\hline \multirow{4}{*}{$\begin{array}{l}\text { MODEL } \\
\text { NO. }\end{array}$} & \multirow{4}{*}{ SERVICE } & \multirow{4}{*}{$\begin{array}{l}\text { PIPE } \\
\text { SIZE } \\
\text { (IN.) }\end{array}$} & \multirow{4}{*}{$\begin{array}{l}\text { CAPACITY } \\
\text { INDEX } \\
\text { (CV) }\end{array}$} & \multirow{2}{*}{\multicolumn{3}{|c|}{$\begin{array}{c}\text { CLOSE-OFF RATINGS } \\
\text { WHEN USED } \\
\text { WITH LINKAGES }\end{array}$}} & \multicolumn{4}{|c|}{ VALVE DIMENSIONS } & \multirow{4}{*}{$\begin{array}{l}\text { VALVE } \\
\text { END } \\
\text { CONNEC } \\
\text { TIONS }\end{array}$} \\
\hline & & & & & & & \multirow{2}{*}{\multicolumn{2}{|c|}{$\begin{array}{l}\text { FACE-TO- } \\
\text { FACE }\end{array}$}} & \multirow{2}{*}{\multicolumn{2}{|c|}{\begin{tabular}{|l} 
CENTER \\
LINE TO \\
BOTTOM \\
\end{tabular}}} & \\
\hline & & & & \multirow{2}{*}{$\begin{array}{l}\text { O618A } \\
80 \text { LB } \\
\text { LINKAGE }\end{array}$} & \multirow{2}{*}{$\begin{array}{l}\text { Q618A } \\
160 \text { LB } \\
\text { LINKAGE }\end{array}$} & \multirow{2}{*}{ Q601E } & & & & & \\
\hline & & & & & & & IN. & MM & IN. & $M M$ & \\
\hline \multirow{7}{*}{ V5013A } & \multirow{7}{*}{ Mixing $\mathrm{C}$} & $1 / 2$ & 2.5 & $140 \mathrm{psig}$ & $150 \mathrm{psig}$ & - & $3 \cdot 1 / 8$ & 79.5 & 2. $3 / 4$ & 70 & \multirow{7}{*}{ Screwed } \\
\hline & & $1 / 2$ & 4.0 & 130 psig & 150 psig & - & $3 \cdot 1 / 8$ & 79.5 & 2. $3 / 4$ & 70 & \\
\hline & & $3 / 4$ & 6.3 & 120 psig & $150 \mathrm{psig}$ & - & $3 \cdot 3 / 8$ & 85.5 & $2 \cdot 19 / 32$ & 66 & \\
\hline & & 1 & 10.0 & 70 psig & 150 psig & - & $3-7 / 8$ & 98.5 & $2 \cdot 27 / 32$ & 72 & \\
\hline & & $1.1 / 4$ & 16.0 & - & $146 \mathrm{psig}$ & - & $4 \cdot 1 / 4$ & 108 & $2 \cdot 23 / 32$ & 69 & \\
\hline & & $1.1 / 2$ & 25.0 & 35 psig & $98 \mathrm{psig}$ & - & $4 \cdot 3 / 4$ & 120.5 & 2. $7 / 8$ & 73 & \\
\hline & & 2 & 40.0 & $20 \mathrm{psig}$ & $67 \mathrm{psig}$ & - & $5.7 / 8$ & 149 & 3. $1 / 4$ & 82.5 & \\
\hline \multirow{6}{*}{ V5013B } & \multirow{6}{*}{ Mixing $c$} & $2 \cdot 1 / 2$ & 63.0 & - & $32 \mathrm{psig}$ & - & $9 \cdot 1 / 2$ & 241.5 & $6 \cdot 7 / 16$ & 163.5 & \multirow{6}{*}{ Flanged $^{b}$} \\
\hline & & 3 & 100.0 & - & $22 \mathrm{psig}$ & - & 11 & 279.5 & 6. $5 / 8$ & 168.5 & \\
\hline & & 4 & 160.0 & - & - & 9 psig & 13 & 330 & $8 \cdot 11 / 16$ & 220.5 & \\
\hline & & 5 & 250.0 & \multicolumn{3}{|c|}{$\begin{array}{l}\text { Not recommended for tight } \\
\text { close-off }\end{array}$} & 15 & 381 & 9. $5 / 8$ & 244.5 & \\
\hline & & 6 & 360.0 & \multicolumn{3}{|c|}{$\begin{array}{c}\text { Not recommended for tight } \\
\text { close-off. }\end{array}$} & $16 \cdot 1 / 2$ & 419 & $10-11 / 16$ & 271.5 & \\
\hline & & $8 \mathrm{e}$ & 600.0 & \multicolumn{3}{|c|}{$\begin{array}{c}\text { Not recommended for tight } \\
\text { close-off }\end{array}$} & $21 \cdot 3 / 8$ & 543 & 14 & 355.5 & \\
\hline \multirow{6}{*}{ V5013C } & \multirow{6}{*}{ Diverting $d$} & $2 \cdot 1 / 2$ & 63.0 & - & $32 \mathrm{psig}$ & - & $9 \cdot 1 / 2$ & 241.5 & 6. $7 / 16$ & 163.5 & \multirow{6}{*}{ Flanged $b$} \\
\hline & & 3 & 100.0 & - & 22 psiq & - & 11 & 279.5 & 6. $5 / 8$ & 168.5 & \\
\hline & & 4 & 160.0 & - & - & 9 psig & 13 & 330 & $8 \cdot 11 / 16$ & 220.5 & \\
\hline & & 5 & 250.0 & \multicolumn{3}{|c|}{$\begin{array}{l}\text { Not recommended for tight } \\
\text { close-off. }\end{array}$} & 15 & 381 & 9. $5 / 8$ & 244.5 & \\
\hline & & 6 & 360.0 & \multicolumn{3}{|c|}{$\begin{array}{l}\text { Not recommended for tight } \\
\text { close-off. }\end{array}$} & $16-1 / 2$ & 419 & $10-11 / 16$ & 271.5 & \\
\hline & & $8 \mathrm{e}$ & 600.0 & \multicolumn{3}{|c|}{$\begin{array}{l}\text { Not recommended for tight } \\
\text { close-off. }\end{array}$} & $21 \cdot 3 / 8$ & 543 & 14 & 355.5 & \\
\hline
\end{tabular}

a Represents maximum pressure difference between the outlet and either of the two inlets lor between the inlet and either of the two outlets).

bFlanged bodies conform to A.S.A. specifications for cast-iron pipe flanges and flanged fittings. Valve flanges are flat faced with a smooth finish. dFor diverting service only.

cFor mixing service only.

e Use industrial type of 01 operator.

(continued on page 3)

\section{ORDERING IINORNATION}

\section{WHEN ORDERING REFER TO THE TRADELINE CATALOG OR PRICE SHEETS FOR COMPLETE ORDERING} SPECIFICATION NUMBER, OR...

\section{SPECIFY-}

1. MODEL NUMBER.

2. VALVE SIZE IN INCHES.

3. CAPACITV INDEX (CV) FOR $1 / 2$ INCH V5013A.

4. ACCESSORIES OR REPLACEMENTS, IF DESIRED.
ORDER FROM-

1. YOUR USUAL SOURCE, OR

2. HONEYWELL 1885 DOUGLAS DRIVE NORTH MINNEAPOLIS, MINNESOTA 55422

(IN CANADA-HONEYWELL CONTROLS LIMITED 740 ELLESMERE ROAD SCARBOROUGH, ONTARIO)

INTERNATIONAL SALES AND SERVICE OFFICES IN ALL PRINCIPAL CITIES OF THE WORLD. 
VALVE LIFT: $3 / 4$ in. [19 ind for models up to 3 inches; $1-1 / 2$ in. [ $38 \mathrm{~mm}$ ] for 4 to 6 inch models; 2 in. $[51 \mathrm{~mm}]$ for 8 inch models.

\section{PACKING LIMITATIONS:}

Water-150 psig maximum pressure; $40 \mathrm{~F}[4 \mathrm{C}] \mathrm{mini}$ mum temperature, $240 \mathrm{~F}[116 \mathrm{C}]$ maximum temperature.

For alternative hot and cold water-140 F [60 C] maximum differential temperature.

V5013B,C hot water service-100 psig maximum pressure.

\section{MATERIALS:}

\begin{tabular}{c|c|c}
\hline \multirow{2}{*}{ COMPONENTS } & \multicolumn{2}{|c}{ BODV TYPE } \\
\cline { 2 - 3 } & V5013A & V5013B,C \\
\hline Valve Bodya & Cast-bronze & Cast-iron \\
\hline Stem & Stainless Steel & Stainless Steel \\
\hline Plug & Brass & Bronze \\
\hline Seat & Integral Brass & Bronze, Removable \\
\hline Packing & Teflon Cone & Teflon Cone \\
\hline
\end{tabular}

aBody material should be similar to that of the system

in which the valve is installed.
MAXIMUM PRESSURE:

Bronze Body-150 psig at $366 \mathrm{~F}|186 \mathrm{C}| \max$.

Iron Body-125 psig at $353 \mathrm{~F}$ [ $178 \mathrm{C}$ ] max.

For quiet water service-20 psig maximum differential at any position.

MOUNTING MEANS: Valve mounts directly in pipe line. Must be mounted so that control motor shaft is horizontal.

ACCESSORIES AND REPLACEMENTS:

1. Lubricant for the stem and packing (Plasti-Lube No. 2) $-1 / 2$ oz. can, Part No. 311193,2 oz. can, Part No. 311057.

\section{Teflon cone puelking}

-V5013A screw body; order 3 packings, Part No. 310623 , for $1 / 2,3 / 4,1$, or $1.1 / 4$ inch valves; order 4 packings, Part No. 311432 , for $1.1 / 2$ or 2 inch valves.

-V5013B or C flanged body; order 4 packings, Part No. 41035 , for $2-1 / 2$ or 3 inch valves; order 5 packings, Part No. 41036, for 4, 5, and 6 inch valves. For 8 inch V5013B, order Part No. 65401; for 8 inch V5013C, order Part No. 37243.

3. Q601, Q618 linkages-see Table I.

4. See Honeywell Commercial Division publication, form 77.5613 , for V5013 replacement parts list.

\section{INSTALLATION}

\section{CAUTION}

a. Installer must be a trained, experienced serviceman.

b. Before wiring the actuator motor, disconnect power supply to prevent electrical shock and equipment damage.

c. Mixing valves are designed for mixing applications and diverting valves for diverting appli. cations; they are not interchangeable.

d. Install the valve so the fluid flows in the direction of the arrow cast on the body. The valve should be mounted with the operator motor shaft horizontal.

e. Always conduct a thorough checkout when installation is complete.

\section{LOCATION}

In selecting a location, the following must be considered.

1. Make sure sufficient space has been provided for the complete valve assembly. The valve linkage and motor fit over the valve stem. For installation and service, they require 4 inches [ 101.5 millimeters] minimum clearance to the length required for the motor and linkage.

2. The Modutrol motor must be mounted with the shaft horizontal.

3. The linkage should not be mounted below the valve where moisture or dirt may accumulate.
The ambient temperature must not exceed the maximum limits for the valve or motor. Controlled liquid. pressure must not exceed the maximum pressure limits of the valve.

\section{PIPING HOOKUPS}

All piping must comply with Incal condes and ordinances. Refer to Figs. 1.5 for typical piping hookups.

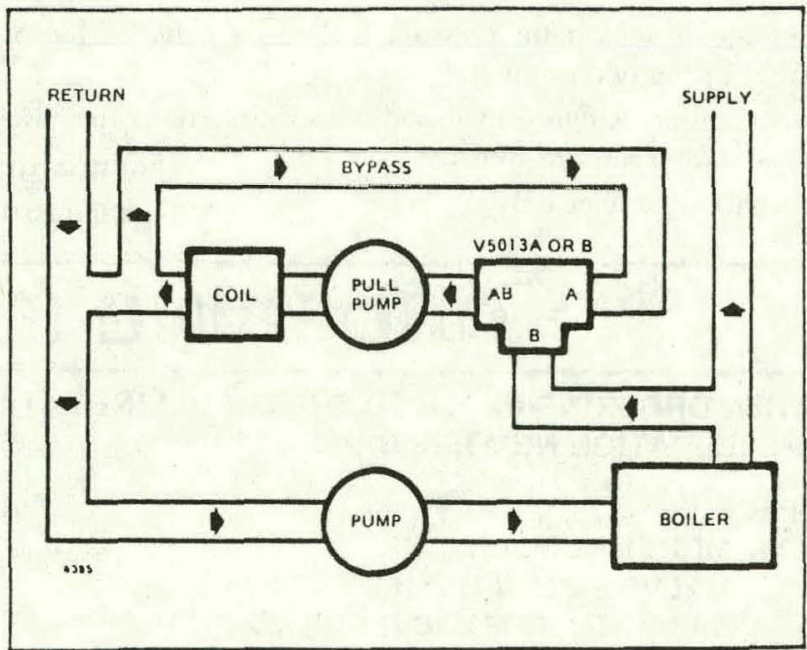

FIG. 1-TYPICAL V5013A OR B MIXING VALVE WITH CONSTANT VOLUME THROUGH COIL. FOR TYPICAL MOTOR-CONTROLLER WIRING, SEE FIG. 8. 


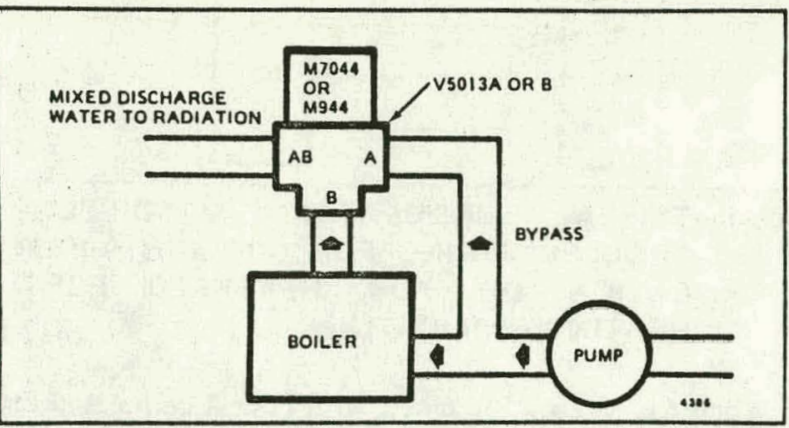

FIG. 2-SINGLE ZONE BYPASS FOR RESET CON. TROL. FOR TYPICAL MOTOR-CONTROL. LER WIRING, SEE FIG. 8.

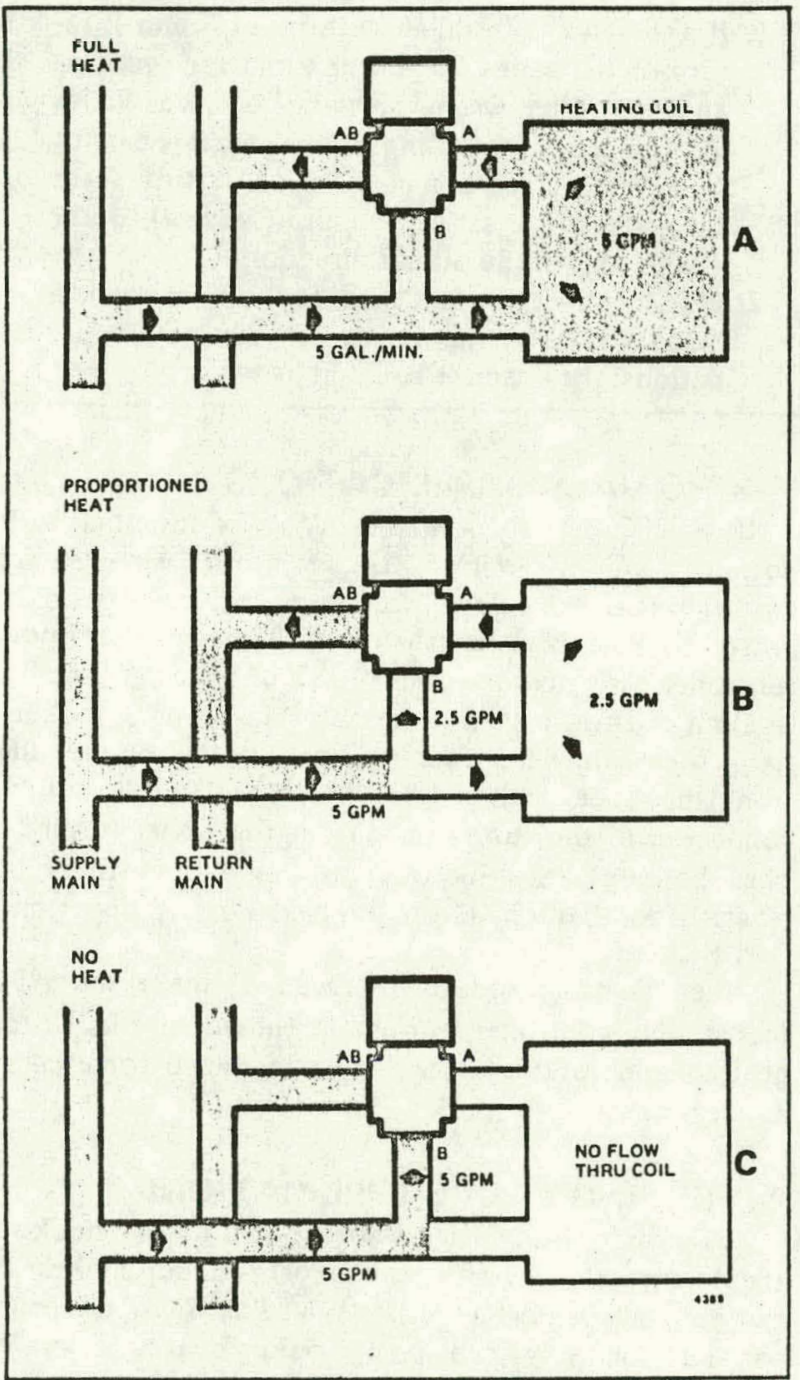

FIG. 3-THREE-WAY VALVE OPERATION-COIL BYPASS. THREE-WAY VALVES MAINTAIN CONSTANT FLOW IN THE PIPING. AS THE TEMPERATURE REQUIREMENTS CHANGE, THE VOLUME OF THE FLUID IN THE COIL VARIES. FOR TYPICAL MOTOR-CONTROLLER WIRING HOOKUP, SEE FIG. 9.

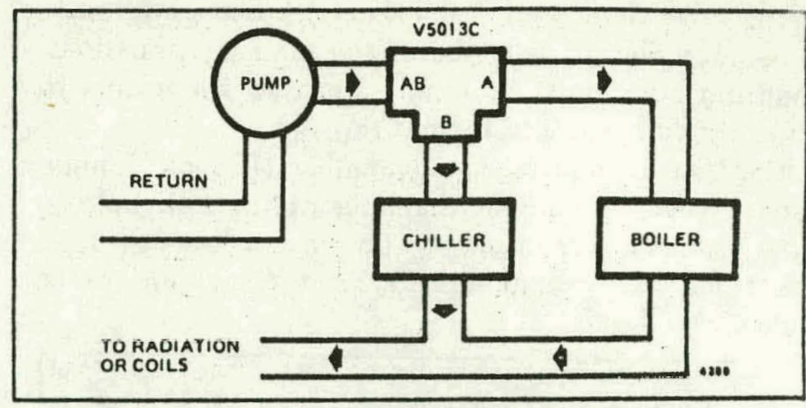

FIG. 4-V5013C DIVERTING VALVE USED TO CHANGEOVER COMPLETE SYSTEM. FOR TYPICAL MOTOR-CONTROLLER WIRING, SEE FIG. 8.

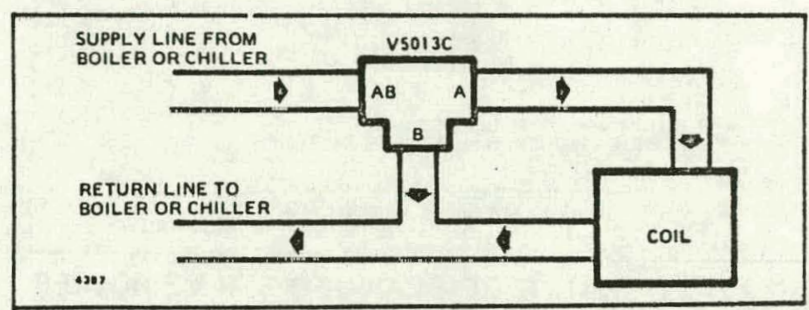

FIG. 5-TYPICAL ZONE HOOKUP OF V5013C USED TO CONTROL FLOW THROUGH COIL. FOR TYPICAL MOTOR-CONTROLLER WIRING, SEE FIG. 8 FOR HEATING APPLICATION OR FIG. 9 FOR COOLING APPLICATION.

\section{VALVE INSTALLATION}

\section{SCREWED VALVE BODIES}

Line up the pipes squarely with the valve at each end. If the pipes are forced into the valve, the body may become twisted and improper seating will result. Prevent pipe chips, scale, and dirt from entering the piping since they may lodge in the seat and prevent proper closing. Apply a vise or wrench to the valve only as shown in the following figure.

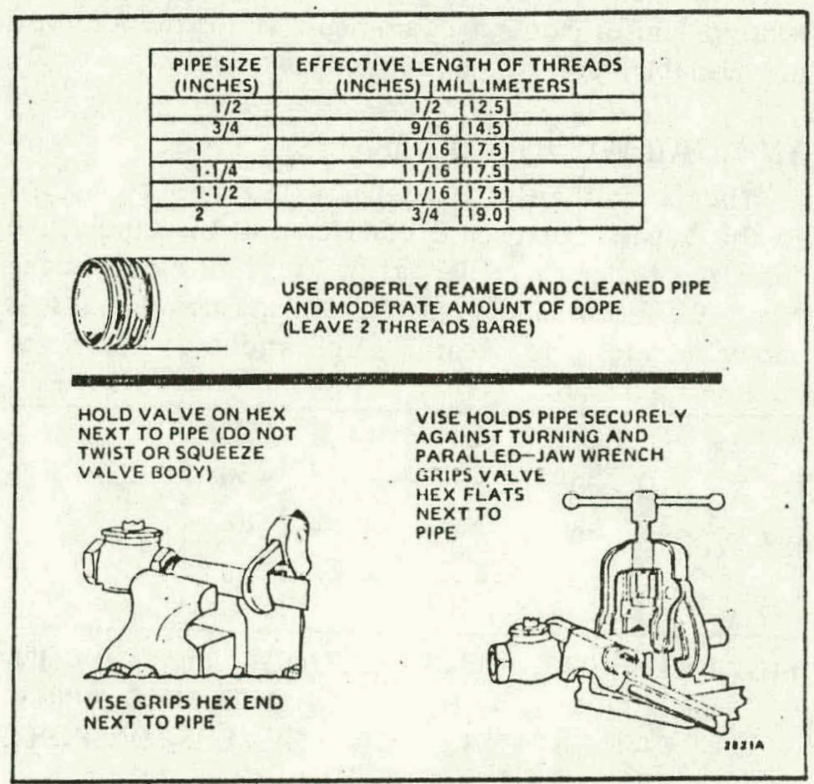

FIG. 6-MOUNTING OF SCREWED VALVE BODIES. 


\section{FLANGED VALVE BODIES}

The valve flanges are flat faced with a smooth finish. Companion flanges must be of the same specifications. Mounting bolts must be long enough to allow nuts to utilize the full length of the nut threads.

The bolts should be approximately $1 / 8$ inch 13 millimeters] smaller than the diameter of the bolt hole to allow clearance for installing. To prevent leakage, use a gasket material recommended for the medium to be handled.

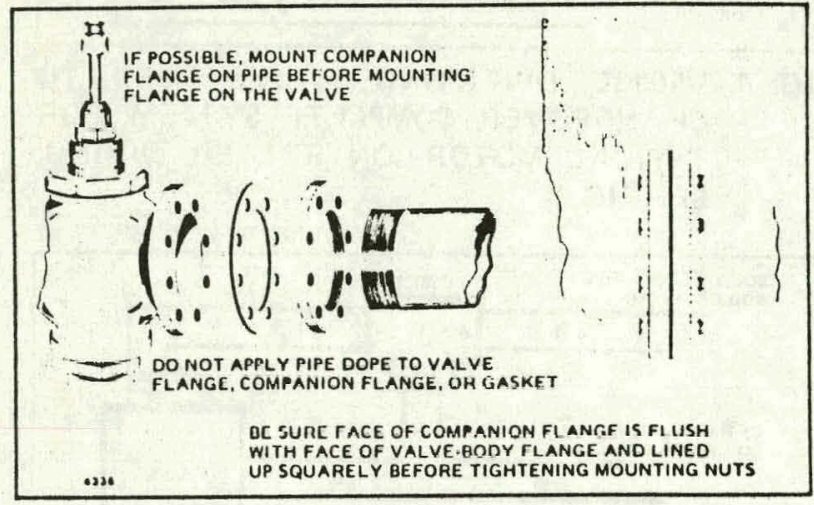

FIG. 7-MOUNTING OF FLANGED VALVE BODIES.

NOTE: For V5013A and $B$, if the pressures in the pipe lines at inlets $A$ and $B$ are unequal, a balancing cock may be installed in the line carrying the higher pressure. Best possible modulation will be obtained if this cock is adjusted under actual operating conditions so that pressures $\mathrm{A}$ and $\mathrm{B}$ are equal at midstroke.

\section{MOTOR-CONTROLLER WIRING}

\section{CAUTION}

Disconnect power supply to prevent electrical shock and equipment damage.

All wiring must comply with local codes and ordinances.

When wiring the modulating motor to the controller, refer to the instructions packed with the motor and heating and/or cooling equipment. If instructions are not available, refer to the following section.

\section{TYPICAL WIRING HOOIKURS}

When a V5013A or B is piped with Port A connected to the bypass and Port B connected in the supply line from the boiler or chiller, as in Fig. 1 or Fig. 2, make series 90 motor and controller wiring connections as shown in Fig. 8 for heating applications or Fig. 9 for cooling applications.

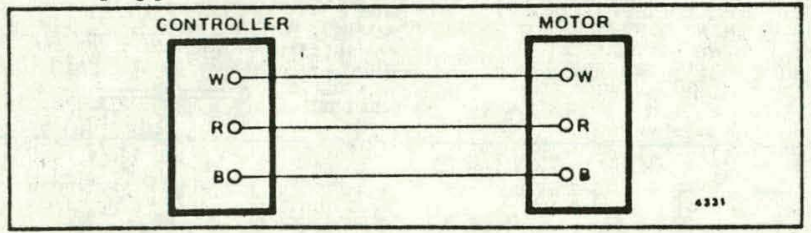

FIG. 8-TYPICAL MODULATING MOTOR-CONTROLLER WIRING FOR HEATING APPLICATION OR FOR REVERSED PORT COOLING APPLICATION.

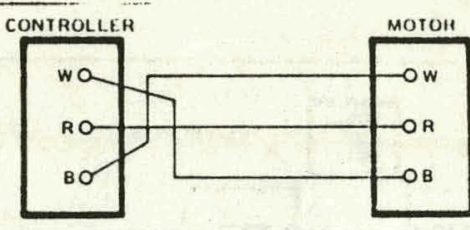

FIG. 9-TYPICAL MODULATING MOTOR-CONTROLLER WIRING FOR COOLING APPLICATION OR FOR REVERSED PORT HEATING APPLICATION.

When the V5013C is piped with Port A connected to the coil and Port B connected in the return line to the boiler or chiller, as in Fig. 5, make series 90 motor and controller wiring connections as shown in Fig. 8 for heating applications or Fig. 9 for cooling applications.

\section{REVERSE PORT HOOKUP WIRING}

\section{CAUTION}

1. If the valve is installed with ports $A$ and $B$ reversed, the series 90 motor (nonspring return) and controller wiring must be reversed. Series 70 and series 90 (spring return) motors cannot be reversed. See applicable specification sheet for series 70 or series 90 (spring return) motor which runs in the proper direction.

2. Mixing valves are designed for mixing applications and diverting valves for diverting applications; they cannot be interchanged.

\section{MIXING VALVE APPLICATIONS}

If a V5013A or B Mixing Valve is installed with Ports $A$ and $B$ reversed (i.e., the hot water enters Port $A$ rather than Port $B$, and the coil bypass is connected to Port B rather than Port A), series 90 motorcontroller wiring connections MUST be reversed (Fig. 3).

On a call for heat in a normal V5013A or B hookup, stem travels upward opening Port $B$, the supply line frum the boiler. When Port $A$ rather than Port $R$ is connected in the supply line from the boiler (reversed port hookup), the motor-controller wiring must be reversed so that on a call for heat Port $A$ opens and Port B closes.

When Ports A and B are reversed, make series 90 motor and controller wiring as shown in Fig. 9 for heating applications or as shown in Fig. 8 for cooling applications.

\section{DIVERTING VALVE APPLICATIONS}

On a call for heat with a V5013C, in a normal hookup, the stem travels upward opening Port $A$ to supply heat to the coil. When Port B rather than Port A is connected to the coil (reversed port hookup), the series 90 motor-controller wiring must be reversed such that on a call for heat Port $B$ opens and Port $A$ closes.

When Ports A and B are reversed, make series 90 motor and controller wiring as shown in Fig. 9 for heating applications or as shown in Fig. 8 for cooling applications. 


\section{V5013A,B MIXING VALVES- HEATING APPLICATION}

A three-way mixing valve should not be used in diverting service.

When the V5013A or B is used in a heating application Port $B$ is connected in the supply line from the hot water boiler, Port $A$ is connected to the bypass, and Port $A B$ is connected to the load. A fall in temperature at the controller will partially open Port B and close Port A to increase the temperature of the water to the load. A rise in temperature at the controller will partially close Port $B$ and open Port $A$ to decrease the temperature of the water to the coil. See Figs. 1, 2, and 10A.

\section{V5013C DIVERTING VALVE- HEATING APPLICATION}

When the V5013C is used in a heating application, Port $A$ is connected to the coil, Purt $B$ is connected to the coil bypass, and Port $A B$ is connected in the supply line from the boiler. A fall in temperature at the controller will close Port B and open Port A to increase the flow of hot water through the coil. An increase in temperature at the controller will close Port $A$ and open Port $B$ to decrease the flow of hot water through the coil. See Figs. 5 and 10B.

\section{V5013C USED AS \\ AUTOMATIC CHANGEOVER}

When the V5013C (Figs. 4 and 10C) is used as an automatic changeover, Port $\mathrm{A}$ is connected in the supply line to the boiler, Port B is connected in supply line to the chiller and Port $A B$ is connected in the return line from the load. A fall in temperature at the controller will close Port B to isolate the cooling equipment and open Port $A$ to increase the coil temperature. An increase in temperature at the controller will close Port $A$ to isolate heating equipment and open Port $B$ to decrease coil temperature.

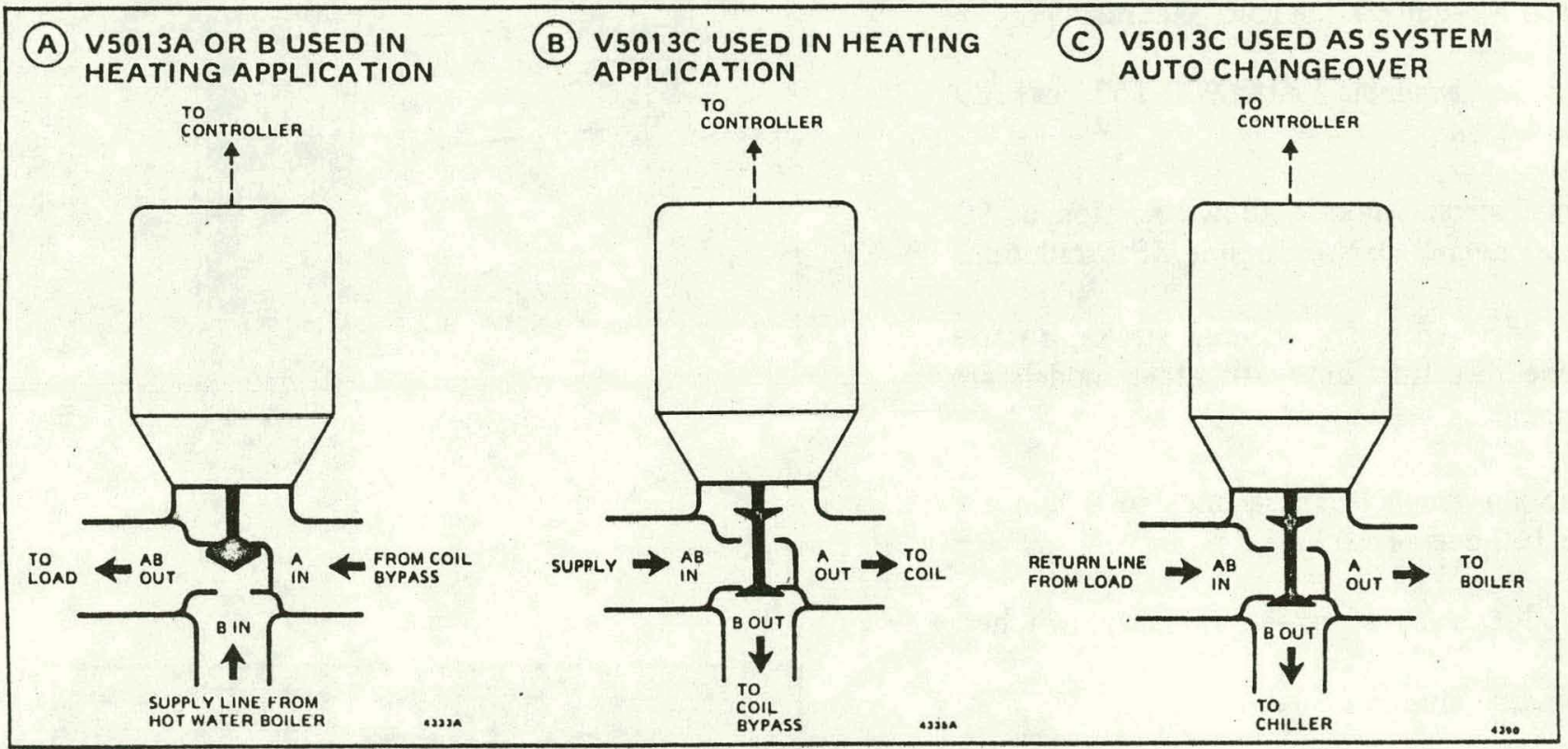

FIG. 10-V5013A-C VALVE HOOKUPS.

\section{CHECKOUT}

It is important to check the valve stem to see that it operates freely. Impaired valve stem operation may indicate that the body was twisted by faulty piping or the stem was bent by rough handling. Either of these conditions may warrant replacement of the valve body or other components.
The valve should be checked at regular intervals for leakage around the packing. The packing is spring-loaded and should seldom require attention. If leakage is discovered and inspection shows that the packing gland is screwed down tightly, the valve must be repacked. 
THE M644 TWO POSITION MODUTROL MOTORS OPEN AND CLOSE DAMPERS AND VALVES ACCORDING TO THE DEMANDS OF AN SPDT, SNAP-ACTING CONTROLLER.

M644A,C,D,E require a $24 \mathrm{~V}$ controller; $\mathrm{M} 644 \mathrm{~B}, \mathrm{~F}$ require a line voltage controller.

$\square$ Models available with 90,160 , or 180 degree stroke.

Dual stroke models allow selection of 90 or 160 degree stroke at time of installation.

$\mathrm{M} 644 \mathrm{~F}$, with 180 degree stroke, rotates in one direction only. All other models are reversing.

Timing range is 15 seconds to 4 minutes for a 160 degree stroke.

M644D,E have built-in auxiliary switches.

Die-cast aluminum case.

Oil-Immersed motor and gear train.

Weatherproofing kit, explosion-proof housing, auxiliary switches, and linkages available as accessories.

J.A.

REV. 3.73
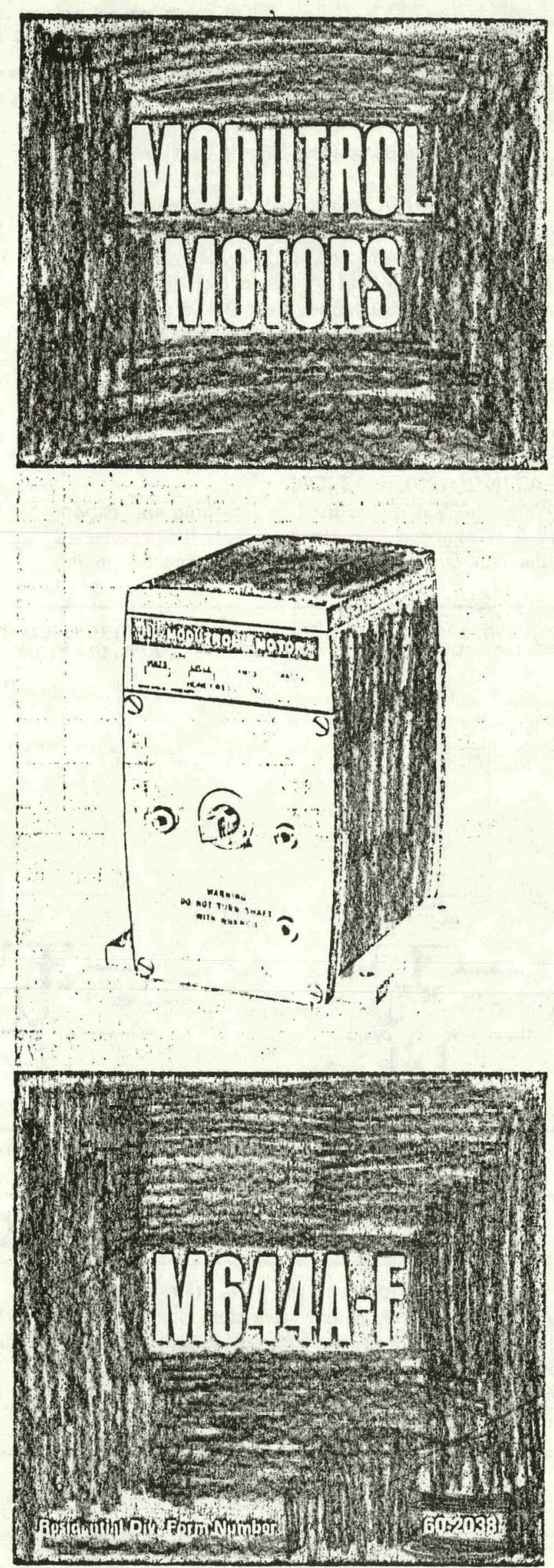


\section{SPPECIIFICATIIONS}

TRADELINE MODELS

Tradeline models are selected and paokaged to provide ease of stocking, ease of handling, and maximum replacement value. Tradeline model specifications are the same as those of standard models except as noted below.

TRADE LINE MODEL A VAILA BLE: M644A

Modutrol Motor.

ELECTRICAL RATINGS:

STROKE: 160 degrees.

Voltage $-24 \mathrm{~V}$ ac.

Frequency $-50 / 60 \mathrm{~Hz}$.

Power Consumption -14 watts, 17 VA.

TIMING: 60 seconds.

ADDITIONAL FEATURES: Tradeline pack with cross reference label.

MODELS:

STANDARD MODELS

\begin{tabular}{|c|c|c|c|c|c|c|}
\hline \multirow[t]{2}{*}{ MODEL } & \multirow{2}{*}{$\begin{array}{l}\text { VOLTAGE } \\
50 / 60 \mathrm{HZ}\end{array}$} & \multicolumn{2}{|c|}{$\begin{array}{c}\text { POWER } \\
\text { CONSUMPTION } \\
\end{array}$} & \multirow[t]{2}{*}{ TIMING } & \multirow{2}{*}{$\begin{array}{c}\text { MAXIMUM } \\
\text { OPERATING } \\
\text { TORQUE } \\
\text { (in lb. -in.) }\end{array}$} & \multirow{2}{*}{$\begin{array}{c}\text { STROKE } \\
\text { (IN DEGREES) }\end{array}$} \\
\hline & & WATTS & VA & & & \\
\hline \multirow{3}{*}{ M644A } & \multirow{3}{*}{24} & \multirow{3}{*}{14} & \multirow{3}{*}{17} & 15 sec. & 37 & 160 \\
\hline & & & & 30 sec. & 150 & 30 \\
\hline & & & & $1 \mathrm{~min}$. & 150 & 160 \\
\hline \multirow{2}{*}{ M644B } & \multirow{2}{*}{120} & \multirow{2}{*}{13} & \multirow{2}{*}{16} & $15 \mathrm{sec}$. & 37 & \multirow{2}{*}{160} \\
\hline & & & & 30 sec. & 75 & \\
\hline \multirow{2}{*}{ M644C } & \multirow{2}{*}{24} & \multirow{2}{*}{14} & \multirow{2}{*}{17} & $\begin{array}{r}15 \text { or } \\
30 \text { sec. }\end{array}$ & 75 & \multirow{2}{*}{90 or $160^{a}$} \\
\hline & & & & $\begin{array}{c}2 \text { or } 4 \\
\text { min. }\end{array}$ & 150 & \\
\hline$M 644 D^{b}$ & 24 & 14 & 17 & $\begin{array}{r}30 \text { or } \\
60 \text { sec. }\end{array}$ & 150 & 90 or $160^{a}$ \\
\hline $\mathrm{M} 644 \mathrm{~Eb}^{\mathrm{b}}$ & 24 & 14 & 17 & $\begin{array}{l}30 \text { or } \\
60 \mathrm{sec} .\end{array}$ & 150 & 90 or $160^{\mathrm{a}}$ \\
\hline $\mathrm{M} 644 \mathrm{FC}$ & 120 & 13 & 16 & 30 sec. & 75 & 180 \\
\hline
\end{tabular}

astroke is field adjustable.

b M644D has 2 auxiliary switches; M644E has 1 auxiliary switch.

$c_{\text {Rotates in only one direction. }}$

AUXILIARY SWITCH RATINGS (in amps):

M644D (2 spdt auxlliary switches)-

\begin{tabular}{l|c|c|c}
\hline & $120 \mathrm{~V}$ & $240 \mathrm{~V}$ & $277 \mathrm{~V}$ \\
\hline Full Load & 5.8 & 2.8 & - \\
\hline Locked Rotor & 34.8 & 17.4 & \\
\hline Resistive & 11.0 & 11.0 & 11.0 \\
\hline
\end{tabular}

M644E (1 spdt auxiliary switch)-

\begin{tabular}{l|c|c}
\hline & $120 \mathrm{~V}$ & $240 \mathrm{~V}$ \\
\hline Full Load & 7.2 & 3.6 \\
\hline Locked Rotor & 43.2 & 21.6 \\
\hline \multicolumn{2}{|c|}{} \\
\hline
\end{tabular}

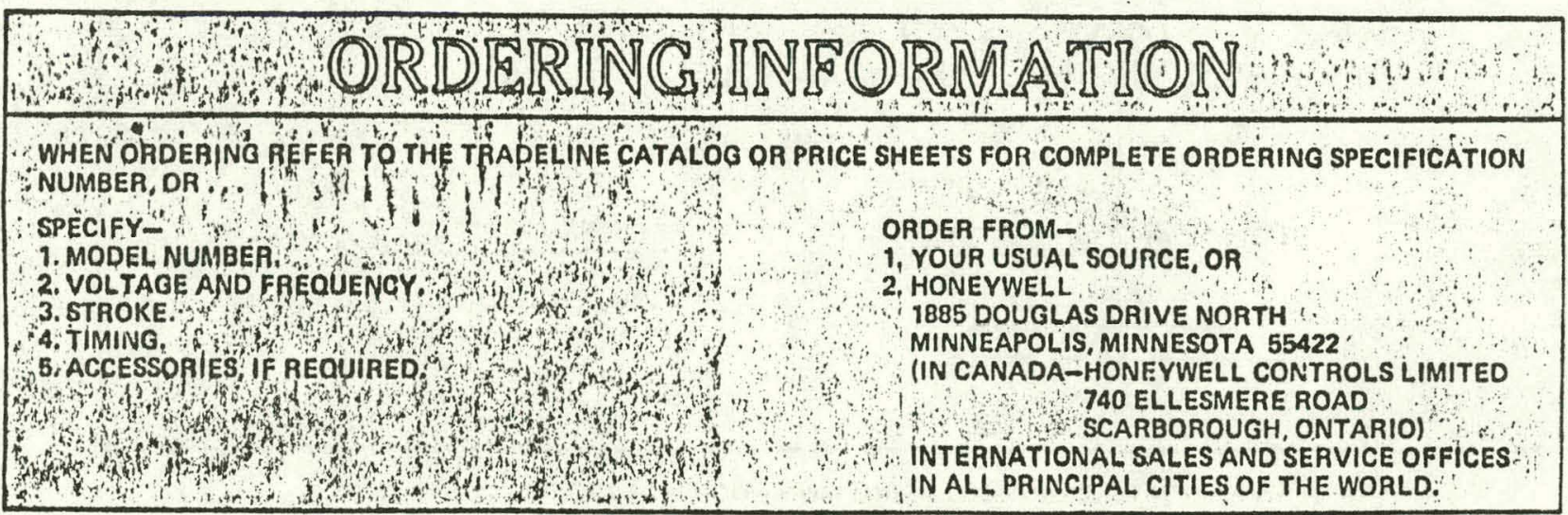


UNDERWRITERS' LABORATORIES, INC. LISTED (M644B, D, E only): File No. E4436, Guide No. XAPX.

NOTE: Only line voltage models and models with auxiliary switch are listed by Underwriters' Laboratorles, Inc.

CANADIAN STANDARDS ASSOCIATION CERTIFIED: M644B, D, E, F. File LR1620, Guide No. 400-E-O.

DEAD WEIGHT LOAD ON SHAFT: Power end-200 pounds; auxiliary end-100 pounds.

TERMINAL CONNECTIONS: M644A-E-screw terminals; M644F-leadwires.

AMBIENT TEMPERAT URE RATING: Maximum-125 $\mathrm{F}$; minimum-minus $40 \mathrm{~F}$.

STROKE: Fixed-90, 160, or 180 degrees; dual90 or 160 , fleld adjustable. See MODELS.

DIMENSIONS: See Fig. 1.

CRANK SHAFT: Double ended shaft, $3 / 8$ inch square. ACCESSORIES:

Q607 Auxiliary Switch-Controls auxiliary equipment as a function of motor position.
Q605 Damper Linkage-Connects motor to damper. Cover-Transformer-Die-cast aluminum cover with built-in transformer.

$130810 \mathrm{~A}-120 \mathrm{~V}, 60 \mathrm{~Hz}$.

$130810 \mathrm{~B}-120 / 208 / 240 \mathrm{~V}, 60 \mathrm{~Hz}$.

$130810 \mathrm{C}-220 \mathrm{~V}, 50 \mathrm{~Hz}$.

$130810 \mathrm{D}-208 / 240 \mathrm{~V}, 50 / 60 \mathrm{~Hz}$.

$130810 \mathrm{E}-208 \mathrm{~V}, 60 \mathrm{~Hz}$.

$130810 \mathrm{~F}-240 \mathrm{~V}, 50 / 60 \mathrm{~Hz}$.

Q601 Linkage-Connects Modutrol motor to water or steam valve.

Q100 Linkage-Connects Modutrol motor to butterfly valve.

Q455 Linkage-Connects Modutrol motor to water or steam valve.

Q618 Linkage-Connects Modutrol motor to water or steam valve.

Weatherprouling Kit (Part No. 7640JS)-Weatherproofs the M644 Modutrol motor.

Motor Crank Arm (Part No. 7616BR)-Included with the Q605 Linkage but not with the motor.

DHE94 Explosion-Proof Housing-Encloses Modutrol motor for use in explosive atmospheres. Not for use with Q601 and Q455 Linkage. Order from Crouse Hinds Co. Requires Honeywell 7617DM Coupling.
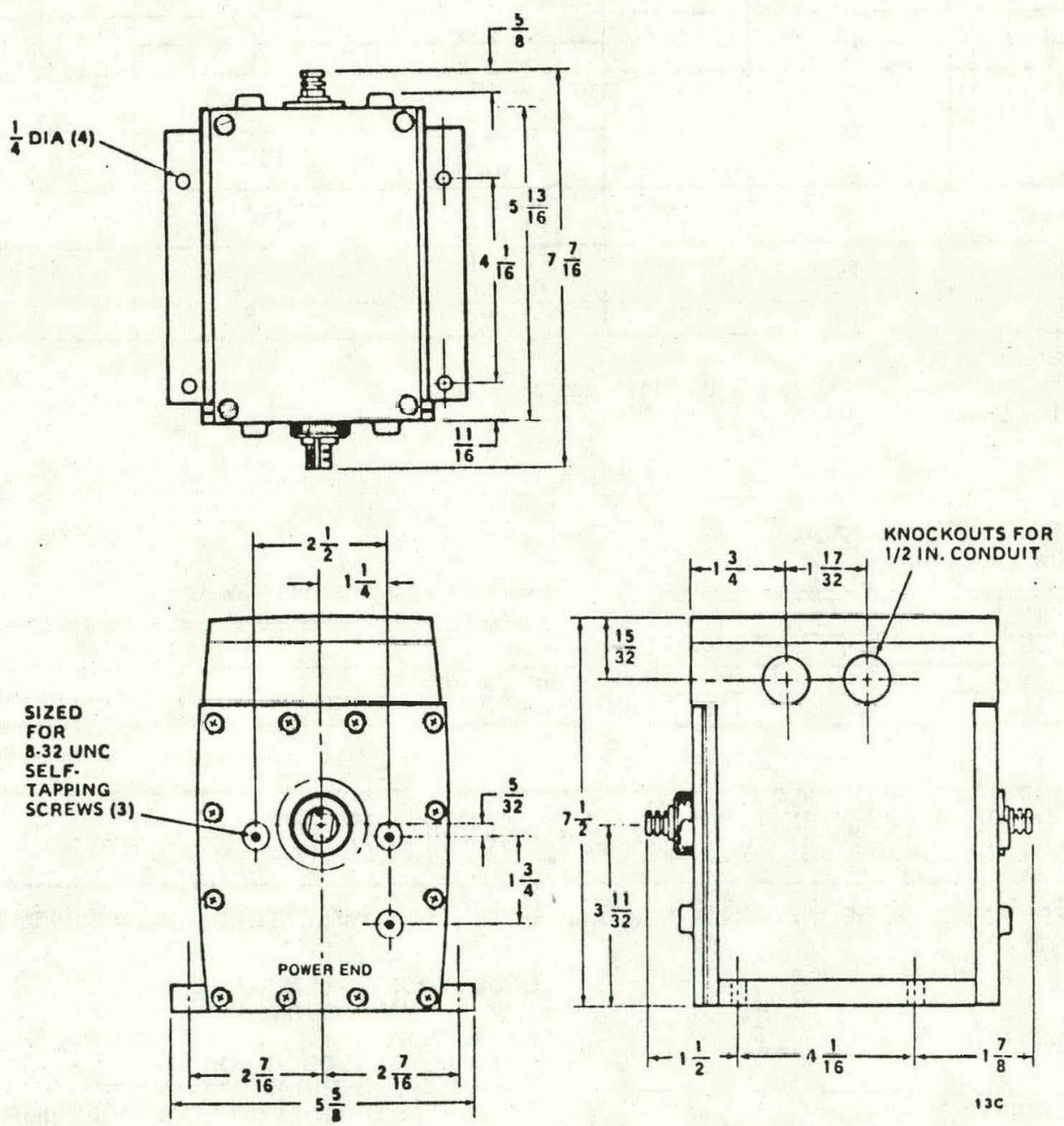

FIG. 1-APPROXIMATE DIMENSIONS OF THE MG44 MODUTROL MOTOR IN INCHES. 


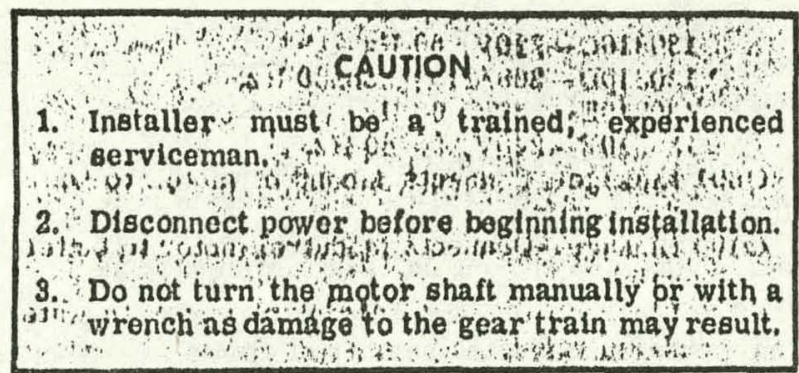

\section{LOCATION}

Install the Modutrol motor in any location except where acid fumes or other deteriorating vapors might attack the exposed metal parts of the motor, or where escaping gases or other explosive mixtures might create a fire hazard.

When choosing a location for the motor, be sure to allow enough space for mounting auxiliary equipment and servicing the motor.

\section{MOUNTING}

The motor has a flange on the bottom for mounting. The mounting holes are sized for $1 / 4$ inch machine screws or bolts. The motor may be mounted in any position as long as the shaft is horizontal.

All M644 Modutrol motors are shipped in the closed position. The closed position for the 160 degree motor is the limit of counterclockw lse rotation as viewed from the power end of the motor, where the groove is on top of the shaft and the flat on the shaft is 10 degrees from horizontal.

The closed position for the 90 degree motor is the same as for the 160 degree motor except that the flat of the shaft is 45 degrees from the horizontal.

The closed position for the M644F (180 degree stroke) is with the groove in the power end of the shaft up and the flat nearly horizontal. The shaft rotates clockwise as viewed from the power end of the motor.

\section{UINKAGES}

The motor comes without a crank arm. The motor crank arm is included in the Q605 Linkage or may be ordered separately (Part No. 7616BR).

For detalled instructions on the assembly of specific linkages, refer to the Instruction sheet packed with each individual IInkage.

When planning for and installing a motor and linkage, check the following points of operation:

1. Attach the valve or damper linkage to the motor crankarm sothat the motor crankarm travels through Its full range while the drive mechanism moves through only its required maximum distance.
2. The motor shaft must travel through its full angular stroke while opening or closing a valve or damper. This holds true even though the full stroke is not required to drive the valve or damper through its required stroke.

3. The motor must be stopped at the end of its stroke by the limit switch and must not be stalled by the damper or valve.

\section{WIRING}

That CAUTín
Disconnect power supply before connecting wiring
toprevent electrical shock or equipment damage.

All wiring must comply with local codes and ordinances. See Figs. 2-6 for typical hookups.

When using a low voltage motor, make certain that the voltage and frequency stamped on the transformer correspond to the characteristics of the power supply. NOTE: Blue $\left(B_{1}\right)$ and white $\left(W_{1}\right)$ connections at the motor may be interchanged if necessary to obtain proper motor action on a temperature (or pressure) change at the controller.

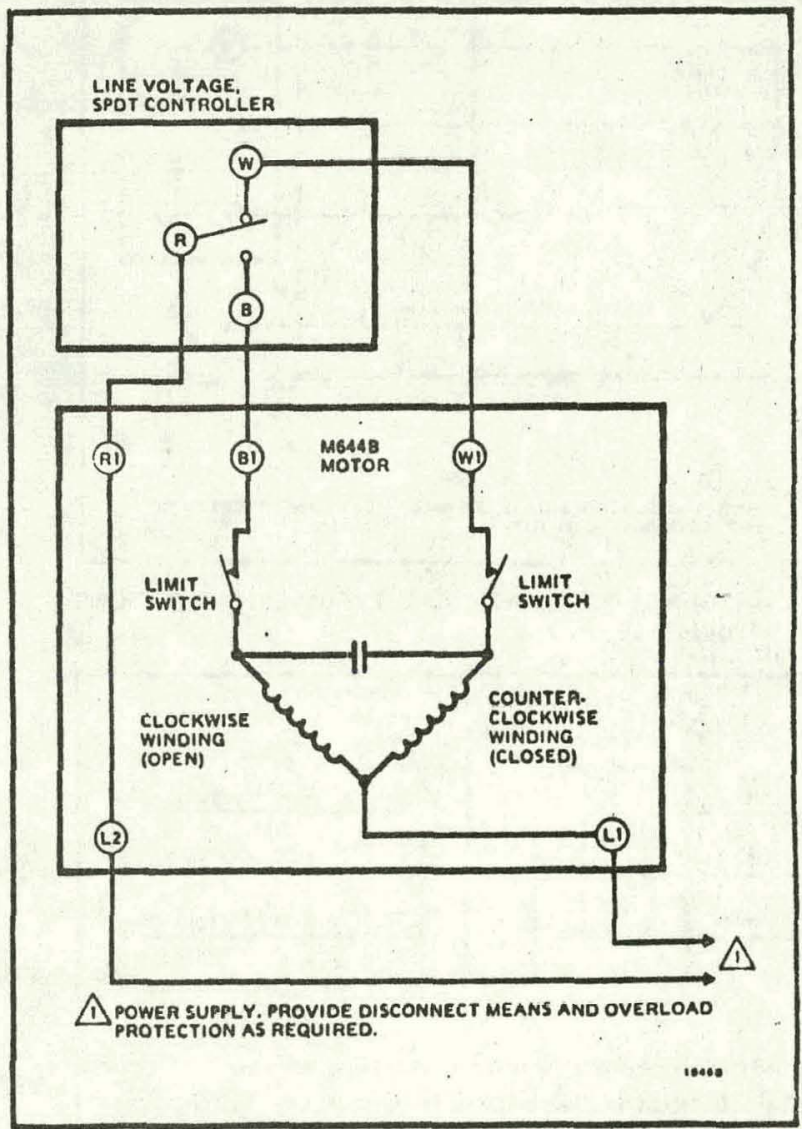

FIG. 2-INTERNAL SCHEMATIC AND TYPICAL CONNECTIONS FOR M644B. 


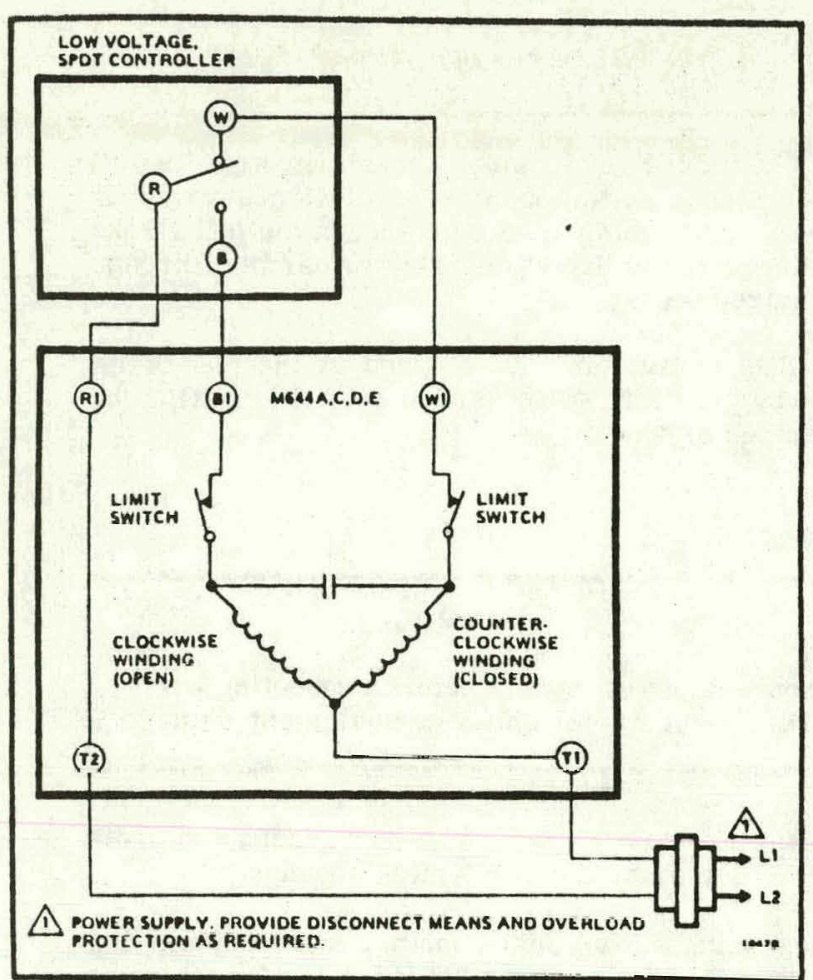

FIG. 3-INTERNAL SCHEMATIC AND TYPICAL CONNECTIONS FOR M644A,C,D,E.

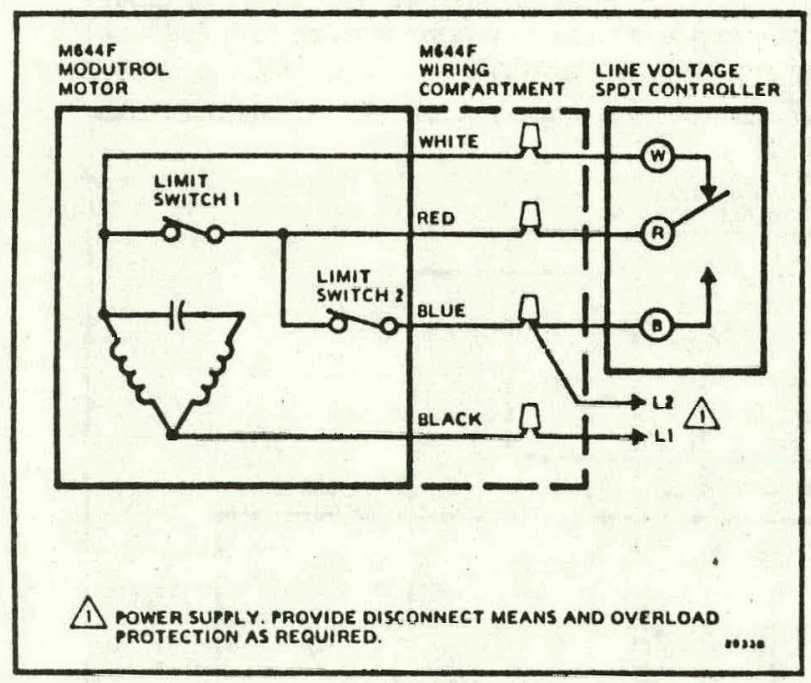

FIG. 4-INTERNAL SCHEMATIC AND TYPICAL CONNECTIONS FOR M644F.

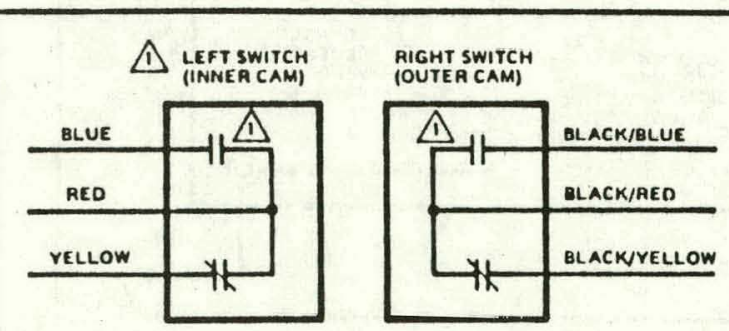

1. MAKES R TO AS MOTOR OPENS.

2. SWITCH LEADS ON ONE SWITCH MOTOR SAME AS LEFT SWITCH ABOVE.

,

FIG. 5-COLOR CODING ON AUXILIARY SWITCH LEADS.
REPLACING A THERMOSTAT-CONTROLLED M204 MODUTROL MOTOR

When the M644 is used to replace a thermostatcontrolled M204 Modutrol Motor, the thermostat must also be replaced to provide correct cycling rate.

Use a $\mathrm{T} 87 \mathrm{~F}$ or $\mathrm{T} 882 \mathrm{~A}$ with the low voltage M6\&4. An initial heat anticipator setting of $0.7 \mathrm{amp}$ is recommended. If this does not produce the desired cycling rate, adjust the thermostat heat anticipator as follows:

- Raise setting to decrease number of cycles.

-Lower setting to increase number of cycles.

Refer to Fig. 6 for the correct electrical hookup. Note that this is not a color-to-color connectlon.

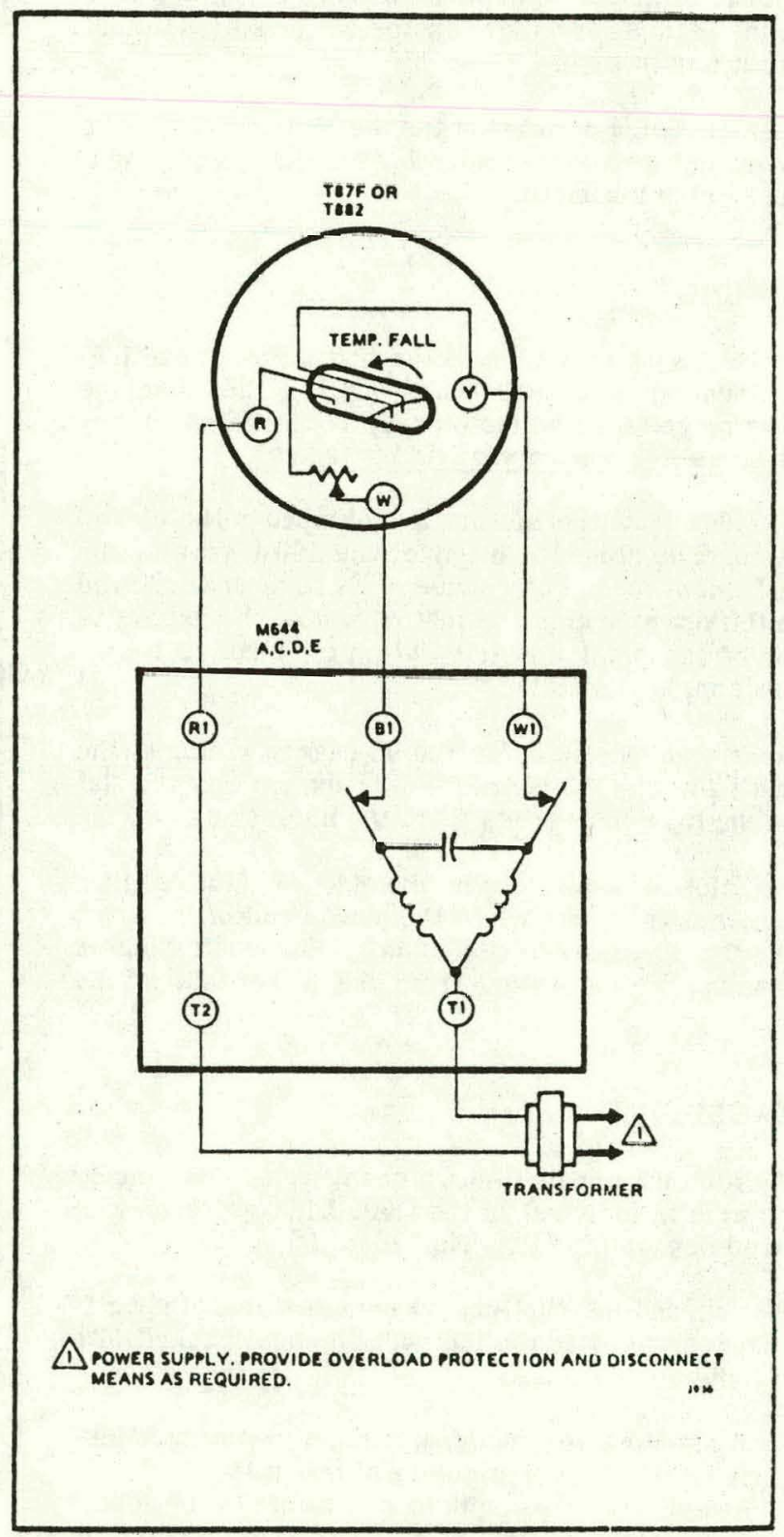

FIG. 6-HOOKUP FOR LOW VOLTAGE M644 MOTOR WHEN CONTROLLED BY A THERMOSTAT. 


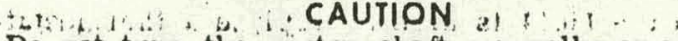

Do not turn the motor shaft manually of with a wrench as damage to the gear train will result.

\section{STROKE ADJUSTMENT (M644C, D, E)}

The stroke is adjusted by changing the position of the $l i m i t$ arms that actuate the limit switches.

\section{STEP 1}

Short motor terminal $\mathrm{R}$ to $\mathrm{B}$ and run the motor to approximately midstroke. St op the motor and remove power while adjustments are in progress. Remove the cover from the auxiliary end of the motor by taking out the four screws securing it.

NOTE: On M644D and E only-be careful not to lose the small spring and washers around the shaft. This spring holds the switch cams in contact with the driving dogs. Remove the switch cams by moving the switch actuating lever away from the cam and pulling the cam assembly straight out.

SIEP 2

Loosen the two screws in the limit arm hub (see Fig. 7). Set the arms at either extreme of their travel. With both arms up, the stroke will be 160 degrees, and with both arms down, the stroke will be 90 degrees. Retighten the two screws.

STEP 3

(On M644D and E models only, replace the switch cams and spring. Make sure the driving dogs engage the switch cams.)

Replace the cover on the auxiliary end of the motor and fasten the four screws removed earlier.

\section{AUXILIARY SWITCH OPERATION}

The auxiliary switches in the M644 are operated by cams on the motor shaft. Each switch is operated by a separate set of cams; the left switch and cams are color-coded blue, and the right switch and cams are color-coded red. M644D has 2 switches, and M644E has $1 \mathrm{sw} / \mathrm{tch}$. The switch makes when its cam roller

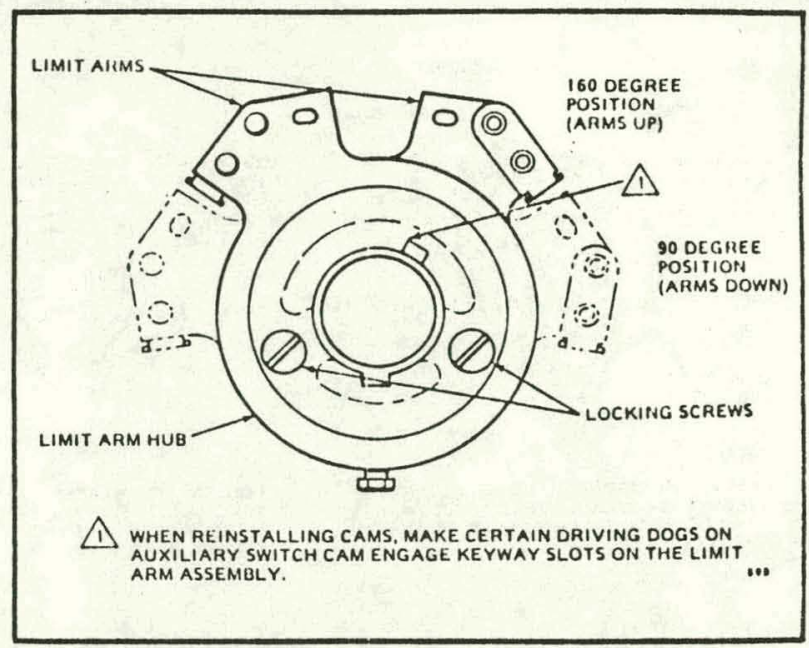

FIG. 7-ADJUSTING LIMIT ARM HUB ASSEMBLY TO CHANGE THE STROKE OF THE MUIUH.

moves to the upper level of the operational cam and breaks when the cam roller moves to the lower level. The differential cam provides an intermediate level; it can be used to increase differential between switch make and break points. The differential is adjustable on M644D and fixed on M644E.

\section{APPROXIMATE SWITCH ADJUSTMENT-M 644D}

(Does not requlre running the motor.)

1. Make sure motor is in the full closed position.

2. Remove the cover from the auxiliary end of the motor by taking out the 4 screws securing it.

3. Remove spring on motor shaft.

4. Push back right cam roller and remove outer cam. Note color code dots.

5. Adjust left switch (inner cam) first. See Fig. 9.

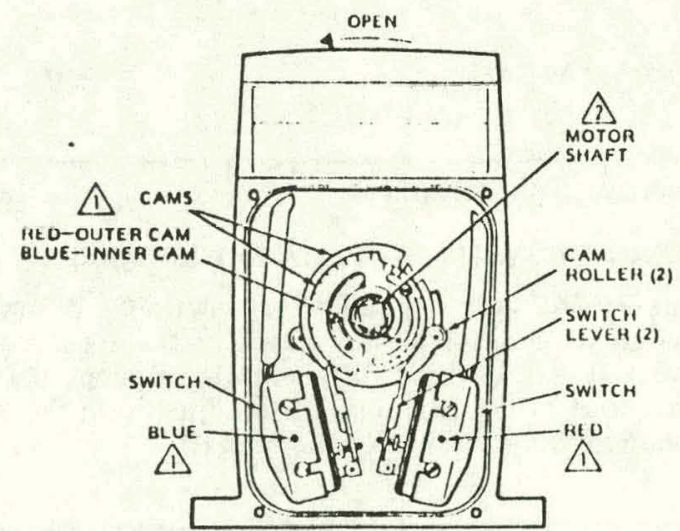

1) COLOR CODING DOT.

2. MOTOR SHOWN AT CLOSED POSITION AS VIEWED FROM AUXILIARY END.

FIG. 8--LOCATION OF INTERNAL AUXILIARY SWITCHES AND SWITCH CAMS IN M644D MODUTROL MOTOR. 
(1)

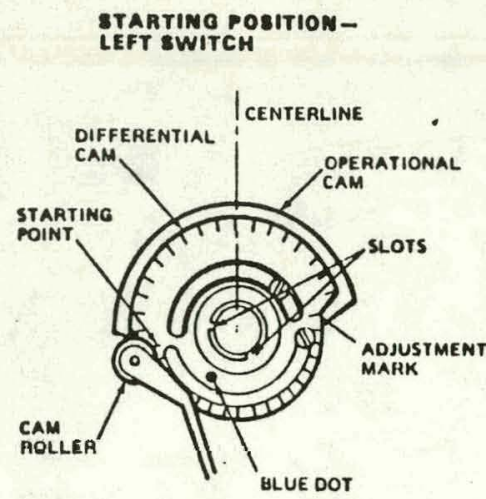

EACH ADJUSTMENT MARK REPRESENTS 10 DEGREES OF MOTOR ROTATION. USE MARKS AND CENTER OF CAM ROLLER AS ADJUST. MENT GUIDE.
(2) ADJUET
OPERATIONAL CAM OPENATIONAL CAM ADJUST DIFFERENTIAL CAM

(4) ILLE DOT WILL BE TO LEFT OF CENTERLINE IF SWITCH IS PNOPERLY ADJUSTED.

LOOSEN OPERATIONAL CAM ADJUSTMENT SCREW. ROTATE BOTH CAMS CW THE NUMBER OF DEGREES MOTOR MUST TRAVEL
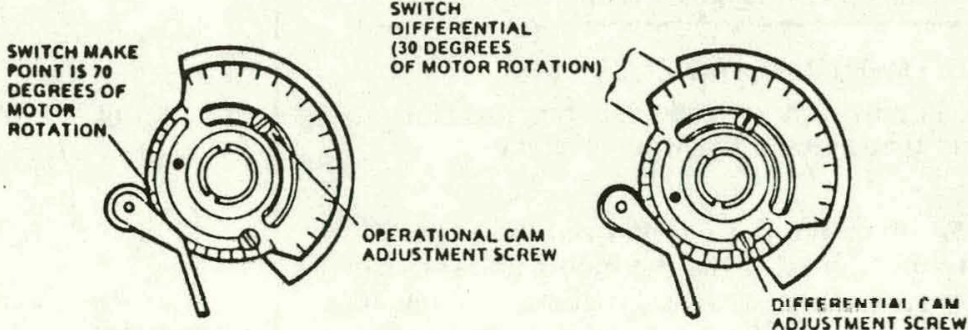

LOOSEN DIFFERENTIAL CAM ADJUSTMENT SCREW. ROTATE DIFFERENTIAL CAM CCW TION FOH SWITCH BREAK. TIGHTEN SCREW.

FIG. 9--ADJUSTING LEFT SWITCH MAKE AND BREAK POINTS.

(1)

\section{MEPLACE CAMS}

ON MOTON

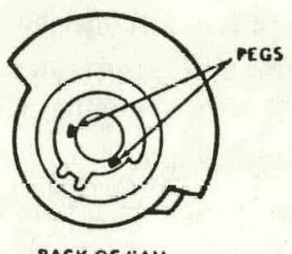

BACK OF CAM

PLACE CAM ON MOTOR SHAFT, FITTING

PEGS INTO SLOTS ON INNER CAM.
(2)

STARTINO POSITION NOTE POSITION

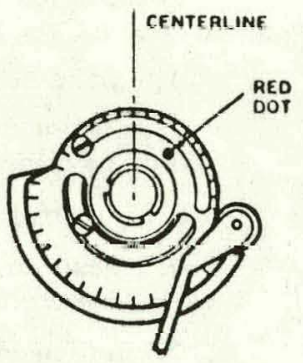

IF CAM IS PLACEO PROPERLY, RED DOT WILL BE TO RIGHT OF CENTERLINE.
(3)

ADJUST CAMBDIOHT SWITCH

4794

(4) MED DOT WILL EE TO RIGHT OF CENTERLINE IF SWITCH IS PROPENLY ADJUETEO.

FIG. 10-ADJUSTING RIGHT SWITCH MAKE AND BREAK POINTS.

6. Put right switch cams on motor shaft and adjust right switch. See Fig. 10.

7. After switches are adjusted, replace spring on motor shaft, then replace auxillary end cover.

\section{EXACT SWITCH ADJUSTMENT-M644D}

(Requilres running the motor.)

Connect a manual potentiometer tothe motor in place of the regular controller and run the motor to the desired position for switch make. Set the switch cam as described under "Approximate Switch Adjustment;" then run the motor back to desired switch break point and set differential cam.

\section{AUXILIARY SWITCH ADJUSTMENT (M644E)}

The M644E has one auxiliary switch. It may be adjusted to operate at any point in the stroke of the motor. It has a fixed differential. Except that the differential is not variable, it is adjusted in the same manner as the switches in the M644D.

\section{IMPORTANT}

The switches on the M644F are used to $11 \mathrm{~m}$ lt the stroke of the motor. They are not adjustable. Do not attempt to adjust or change the setting of thesc switches. 
After installation and linkage adjustinent, check out the entire installation. A good checkout proves that:

a. the motor operates properly,

b. the motor responds to the controller properly;

c. the motor operates the valve or damper as it should.
Energize the motor by setting the controller so its contacts close $R$ to $B$ ur by placing a jumper wire across terminals $R$ and $B$. The motor sliould run smoothly and drive the valve or daniper to the end of its struke. "If it does not, check the source of powir. to be sure there is voltage and thit it is at least 85 percent of the ratedvoltage stamped on the nameplate of the inotor.

\section{OPRERTION}

\section{ALL MODELS EXCEPT M644F}

Whether the M644 is used with a line voltage or low voltage controller the operation is the same.

Refer to Figs, 2 and 3 for an internal schematic diagram of the M644.

When the controller makes in one direction, the motor will run in a corresponding direction. The motor will continue to run in that direction until the IImit of rotation is reached and the limit switch opens, or unt il the controller makes in the opposite direction.
M644F

Refer to Fig. 4 for an internal schematic diagram of the M644F.

When cont roller makes $R$ to $B$, with the motor in the closed position (limit switch in blue lead open), power is applied to motor windings through the cont roller and limit switch 1. When the motor reaches full open, liuit switch 1 opens, stopping the motor.

When controller makes $R$ to $W$ the motor will be powered through limit switch 2, controller, and the white lead. When the motor reaches full closed, limit switch 2 will open, stopping the motor.

WARRANTY "Unless otherwhe apecified, the Company wartents oll Residential Division equipment manuluctured by it alld beating ile liemeplate to be Iree from defectl in workinenship and malosials undes normal use and servlee al follown.

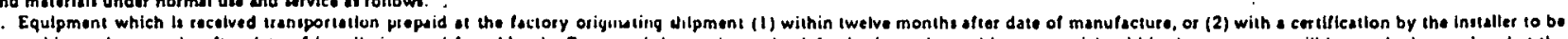

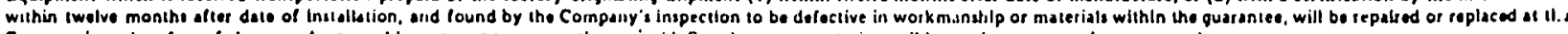

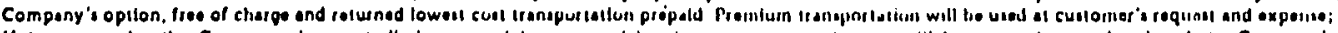

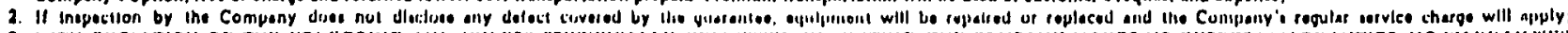

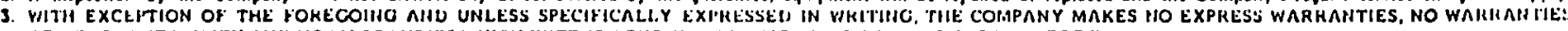
OF MERCHANTABILITY AND NO WARRANTIES WHICH EXTEND UEYOND THE DESCHIPTION ON THE FACE HEREOF."

HONE YWELL. MINNENPOLIS. MINN. 55408 IIITERNATIONAL Sales Ollices in all principal cities of the world. Manulacturing in Australia, Candda, firland, Fience. Germany, Japan, Mexico. Netherlende, Spoln, Tawan, Uniled Kluguem, U.S $\wedge$ 
M944 MODUTROL MOTORS ARE REVERSING, PROPORTIONAL MOTORS USED TO OPERATE DAMPERS OR VALVES IN ELECTRONIC (SERIES 70) OR ELECTRIC (SERIES 90) MODULATING CIRCUITS.

M944A-F,J are low voltage and M944G,K,L are line voltage motors.

$\square$ M944C-E,L stroke is field adjustable to 90 or 160 degrees; stroke is fixed at 90 or 160 degrees on other models.

$M 944 A, C, D, F$ have internal balance relay.

$\square M 944 B, E, G, J-L$ require external balance relay.

Die-cast aluminum case.

Direct drive feedback potentiometer.

$\square$ Rated for ambient temperatures of minus 40 to $125 \mathrm{~F}$ [minus 40 to $55 \mathrm{C}$ ].

Interchangeable with other proportioning motors. Use existing accessories.

$\square$ Available with 2 internal, cam-adjusted auxiliary switches.

$\square$ Available accessories include weatherproofing kit and cover-mounted transformer.
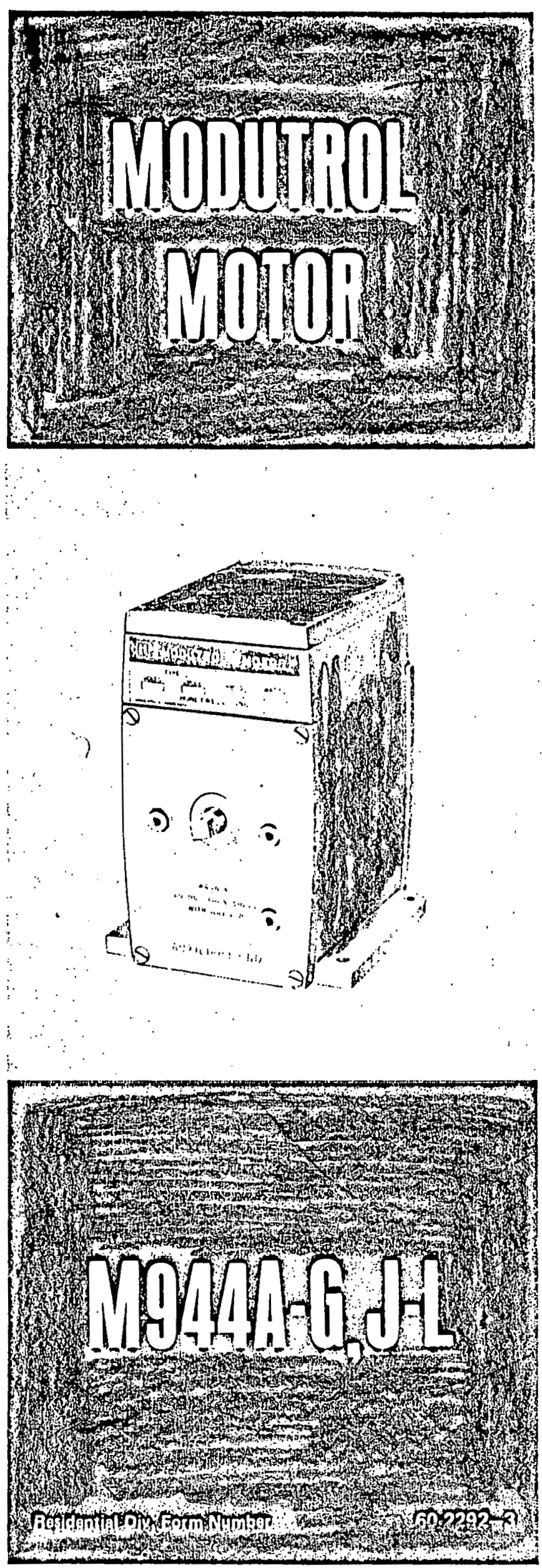

V.J.

REV. $11.75(.073)$ 
TRADELINE MODELS

Tradeline models are selected and packáged to provide ease of stocking, ease of handling, and maximum replacement value. Tradeline model specifications are the same as those of standard models except as noted below. MODELS: M944 Modutrol Motor. For additional model characteristics, refer to the table below.

\begin{tabular}{c|c|c|c|c}
\hline MODEL & $\begin{array}{c}\text { VOLTAGE } \\
50 / 60 \mathrm{HZ}\end{array}$ & $\begin{array}{c}\text { MOTOR } \\
\text { TIMING }\end{array}$ & $\begin{array}{c}\text { STROKE } \\
\text { (DEGREES ROTATION) }\end{array}$ & AUXILIARY SWITCH \\
\hline M944A & $24 \mathrm{~V}$ ac & 60 seconds & Fixed, 160 & - \\
\hline M944B & $24 \mathrm{~V}$ ac & 60 seconds & Fixed, 160 & - \\
\hline M944D & $24 \mathrm{~V}$ ac & 30 or 60 seconds & Dual, 90 or 160 & 2 \\
\hline M944E & $24 \mathrm{~V}$ ac & 30 or 60 seconds & Dual, 90 or 160 & 2 \\
\hline
\end{tabular}

ADDITIONAL FEATURES: Tradeline pack with cross reference label and special instruction sheet.

MODELS: M944 Modutrol Motors.

STANDARD MODELS

\begin{tabular}{|c|c|c|c|c|c|c|}
\hline \multirow{2}{*}{ MODEL } & \multirow{2}{*}{$\begin{array}{l}\text { VOLTAGE } \\
(50 / 60 \mathrm{HZ})\end{array}$} & \multirow{2}{*}{$\begin{array}{c}\text { BALANCE } \\
\text { RELAY }\end{array}$} & \multirow{2}{*}{$\begin{array}{l}\text { STROKE } \\
\text { (DEGREES } \\
\text { ROTATION) }\end{array}$} & \multirow{2}{*}{$\begin{array}{l}\text { MOTOR } \\
\text { TIMING }\end{array}$} & \multicolumn{2}{|c|}{ AUXILIARY FUNCTIONS } \\
\hline & & & & & SWITCHES & POTENTIOMETER \\
\hline \multirow[b]{2}{*}{ M944A } & \multirow[b]{2}{*}{$24 \mathrm{~V}$} & \multirow[b]{2}{*}{ yes } & 90 & $30 \mathrm{sec}$. & \multirow[b]{2}{*}{-} & \multirow[b]{2}{*}{-} \\
\hline & & & 160 & $\begin{array}{c}15 \mathrm{sec} \text {. or } \\
60 \mathrm{sec} .\end{array}$ & & \\
\hline M944B & $24 V$ & no & 160 & $\begin{array}{l}15 \mathrm{sec} ., \\
1 \mathrm{~min} ., \\
\text { or } 4 \mathrm{~min} . \\
\end{array}$ & - & - \\
\hline M944C & $24 \mathrm{~V}$ & yes & $\begin{array}{l}90 \text { or } \\
160^{a} \\
\end{array}$ & $\begin{array}{r}15 \mathrm{sec} . \\
\text { or } 2 \mathrm{~min} . \\
\end{array}$ & - & - \\
\hline M944D & $24 \mathrm{~V}$ & yes & $\begin{array}{l}90 \text { or } \\
160^{a}\end{array}$ & $30 \mathrm{sec}$. & $\because$ & $:-$ \\
\hline M944E & $24 \mathrm{~V}$ & no & $\begin{array}{l}90 \text { or } \\
160 a\end{array}$ & $\begin{array}{c}15 \mathrm{sec} . \\
\text { or } 2 \mathrm{~min} .\end{array}$ & 2 & - \\
\hline M944F & $24 \mathrm{~V}$ & Yes & 160 & $1 \mathrm{~min}$. & - & yes \\
\hline \multirow{2}{*}{ M944G } & \multirow{2}{*}{$120 \mathrm{~V}$} & \multirow{2}{*}{ no } & 90 & 30 sec. & \multirow{2}{*}{-} & \multirow{2}{*}{-} \\
\hline & & & $160 \div$ & $1 \mathrm{~min}$. & & \\
\hline M944J & $24 \mathrm{~V}$ & no & 160 & $1 \mathrm{~min}$. & - & yes \\
\hline M944K & $120 \mathrm{~V}$ & no & 160 & 1 min. & $2 \mathrm{~b}$ & - \\
\hline M944L & $120 \mathrm{~V}$ & no & $\begin{array}{l}90 \text { or } \\
160^{a}\end{array}$ & $2 \mathrm{~min}$. & - & - \\
\hline
\end{tabular}

aStroke is field adjustable. Motor timing shown applies when 90 degree stroke is used; timing doubles when 160 degree stroke is selected.'

buxiliary switches are wired to provide stroke limit also. Auxiliary switches close when motor reaches full open position. (continued on page 3 )

\section{ORDERING INFORMATION}

WHEN PURCHASING REPLACEMENT AND MODERNIZATION PRODUCTS FROM YOUR TRADELINE WHOLESALER OR YOUR DISTRIBUTOR, REFER TO THE TRADELINE CATALOG OR PRICE SHEETS FOR COMPLETE ORDERING NUMBER.

SPECIFY-

1. MODEL NUMBER, TRADELINE IF DESIRED. 3. STROKE AND TIMING.

2. VOLTAGE AND FREQUENCY.

4. ACCESSORIES.

IF YOU HAVE ADDITIONAL OUESTIONS, NEED FURTHER INFORMATION, OR WOULO LIKE TO COMMENT ON OUR PRODUCTS OR SERVICES, PLEASE WRITE OR PHONE:

1. YOUR LOCAL HONEYWELL RESIDENTIAL DIVISION SALES OFFICE (CHECK WHITE PAGES OF PHONE DIRECTORY).

2. RESIDENTIAL DIVISION CUSTOMER SERVICE

HONE YWELL INC., 1885 DOUGLAS DRIVE NORTH

MINNEAPOLIS, MINNESOTA 55422 (612) 542.7500

(IN CANADA-MONEYWELL CONTROLS LIMITED, 740. ELLESMERE ROAD, SCARBOROUGH, ONTARIO M1P 2V9) INTERNATIONAL SALES AND SERVICE OFFICES IN ALL. PRINCIPAL CITIES OF THE WORLD. 
ELECTRICAL CONSUMPTION:

M944A,D,F-18 watts.

M944B,E,J,K-1 4 watts.

M944G, L-1 3 watts.

AUXILIARY SWITCH RATINGS (amps):

M944D,E,K (2 MICRO SWITCH snap-acting switches)-

\begin{tabular}{l|c|c|c}
\hline & $120 \mathrm{~V}$ & $240 \mathrm{~V}$ & $277 \mathrm{~V}$ \\
\hline Full Load & 5.8 & 2.9 & - \\
\hline Locked Rotor & 34.8 & 17.4 & - \\
\hline Resistive & 11.0 & 11.0 & 11.0 \\
\hline
\end{tabular}

TORQUE (in pound-inches):

\begin{tabular}{c|c|c|c}
\hline \multicolumn{2}{c|}{ TIMING } & NORMAL \\
$\begin{array}{c}\text { 90 DEGREE } \\
\text { STROKE } \\
\text { MOTORS }\end{array}$ & $\begin{array}{c}160 \text { DEGREE } \\
\text { STROKE } \\
\text { MOTORS }\end{array}$ & $\begin{array}{c}\text { RUNNING } \\
\text { TOROUE }\end{array}$ & $\begin{array}{c}\text { BREAKAWAY } \\
\text { TOROUEa }\end{array}$ \\
\hline- & $15 \mathrm{sec}$. & 37 & 75 \\
\hline $15 \mathrm{sec}$. & $30 \mathrm{sec}$. & 75 & 150 \\
\hline $\begin{array}{c}30 \mathrm{sec} ., \\
1.2 \mathrm{~min} .\end{array}$ & $\begin{array}{c}1,2,4 \\
\text { min. }\end{array}$ & 150 & 300 \\
\hline
\end{tabular}

aBreakaway torque is the maximum torque available to overcome occasional large loads such as a seized damper or valve. MOTOR MUST NOT BE USED CONTINUOUSLY AT THIS RATING.

\section{DEAD WEIGHT LOAD ON SHAFT:}

Power End-200 pounds maximum.

Auxiliary End-100 pounds maximum.

AMBIENT TEMPERATURE RATINGS:

Maximum-125 F [55 C].

Minimum-minus $40 \mathrm{~F}$ [minus $40 \mathrm{C}$ ].

CRANKSHAFT: Double-ended, $3 / 8$ inch square.

DIMENSIONS: See Fig. 1.
ACCESSORIES:

DHE-94 Explosion-proof Housing-encloses motor for use in explosive atmospheres. Not for use with Q601 and Q455 Linkages. Order separately from Crouse-Hinds Co. Requires Honeywell 7617DM Coupling.

Cover-transformers-die-cast aluminum cover with built-in transformer.

Part No. $130810 \mathrm{~A}-120 \mathrm{~V} \mathrm{ac} ; 60 \mathrm{~Hz}$.

Part No. $130810 \mathrm{~B}-120 / 208 / 240 \mathrm{~V}$ ac; $60 \mathrm{~Hz}$.

Part No. $130810 \mathrm{C}-220 \mathrm{~V} \mathrm{ac} ; 50 \mathrm{~Hz}$.

Part No. 130810D-208/240V ac; $60 \mathrm{~Hz}$.

Part No. $130810 \mathrm{E}-208 \mathrm{~V} \mathrm{ac} ; 60 \mathrm{~Hz}$.

Part No. $130810 \mathrm{~F}-240 \mathrm{~V} \mathrm{ac} ; 60 \mathrm{~Hz}$.

Q607 Auxiliary Switch-controls auxiliary equipment as a function of motor position.

Q605 Damper Linkage-connects motor to damper. INCLUDES MOTOR CRANK ARM.

Q618 Linkage-connects Modutrol motor to water or steam value.

Q601 Linkage-connects Modutrol motor to water or steam valve.

Q100 Linkage-connects Modutrol motor to butterfly valve.

Q209 Potentiometer-limits minimum position of motor.

Qh\& Dyal Contrnl Potentinmeter-controls I through 9 additional motors.

W859 Economizer Control Package-provides controls needed for outdoor and return air damper system.

Q181 Auxiliary Potentiometer-controls 1 or 2 additional motors.

7640JS Weatherproofing Kit-weatherproofs the M944 Modutrol Motor.

7616BR Motor Crank Arm-included with Q605 but not with motor.
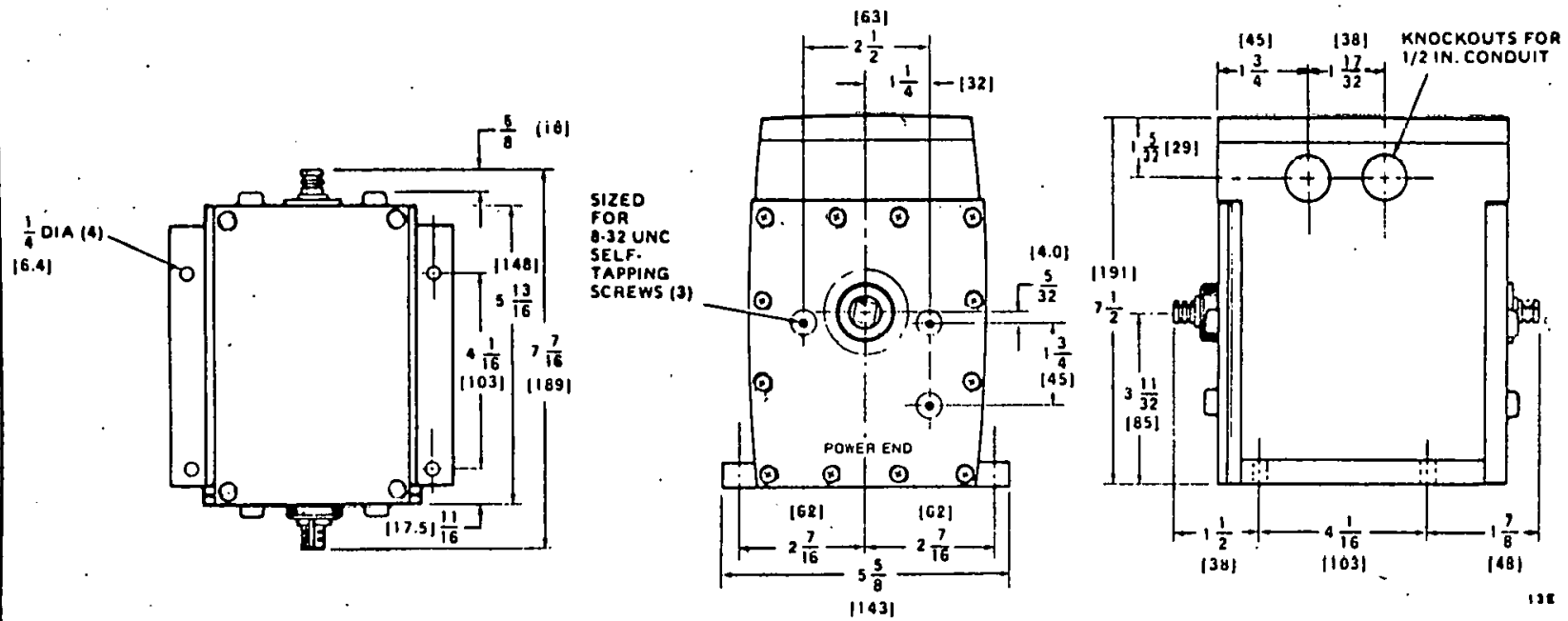

FIG. 1-DIMENSIONS, IN INCHES [IN MILLIMETRES], OF M944 MODUTROL MOTOR. 


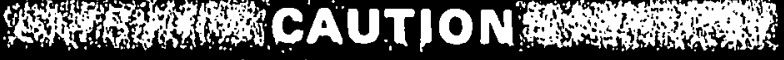

1. Installer must be a trained, experienced serviceman.

2. Disconnect power supply before beginning installation.

3. Do not attempt to turn the motor shaft by hand or with a wrench. Damage to the gear train will result.

4. Always conduct a thorough checkout when installation is complete.

\section{LOCATION}

Install the Modutrol motor in any location except where acid fumes or other deteriorating vapors might attack the metal parts, or in atmospheres of escaping gas or other explosive vapors. Motors are rated for ambient temperatures between minus 40 and $125 \mathrm{~F}$ [minus 40 and $55 \mathrm{C}$ ]. If located outdoors, use weatherproofing kit; see Accessories section.

Allow enough clearance for installing accessories and servicing the motor when selecting a location. See Fig. 1.

\section{MOUNTING}

Always install the motor with the crankshaft horizontal. Mounting flanges extending from the bottom of the motor housing are drilled for $1 / 4$ inch machine screws or bolts.

All M944 motors are shipped from the factory in closed position; i.e., at the limit of counterclockwise 7 rotation as viewed from the power end of the motor, with the groove in the shaft on top. The flat of the shaft is 10 degrees from horizontal on 160 degree stroke models and 45 degrees from the horizontal on 90 degree stroke models.

\section{INSTALLING LINKAGES}

The motor comes without a crank arm. The motor arm is included in the Q605 Linkage or may be ordered separately (see Accessories).

For detailed instructions on the assembly of specific linkages, refer to the instruction sheet packed with each linkage.

In general, however, check the following points of operation when installing a motor and linkage.
1. Linkages for valves and louver ty pe dampers should be adjusted so that the damper or valve moves through only the maximum required distance when the motor moves through its full stroke.

2. With modulating control, maximum damper opening should be no more than 60 degrees. Little additional airflow is provided beyond this point.

3. The motor must be stopped at the end of its stroke by the limit switch and must not be stalled by the damper or valve. The motor will be damaged if it is not permitted to complete its full stroke.

4. Do not exceed the motor ratings in any installation.

\section{WIRING}

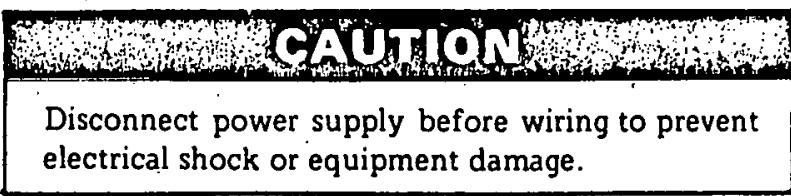

All wiring must agree with applicable codes, ordinances, and regulations.

Make sure that the voltage and frequency stamped on the motor correspond to the characteristics of the power supply.

Figs. 2-5 show internal schematics for the M944 motors, and Figs. 6-12 show some typical system connections.

\section{IMPORTANT}

After the valve or damper linkage is connected to the motor, it may be necessary to interchange the blue and yellow connections at the motor terminals to obtain the proper action of the valve or damper on a temperature increase or decrease at the controller.

If a motor operates in a direction opposite of the rotation desired, the rotation can be reversed by switching wires at either the motor or the panel. With the M944A, $C, D$, and $F$ motors, reverse wires at the $B l$ and $W I$ terminals. With M944B,E,G,J, and L motors, reverse the wires at the 1 and 2 terminals and the $Y$ and $G$ terminals. On the M944K motor, reverse the wires at the 1 and 3 terminals, and the 4 and 6 terminals.

NOTE: In most applications a single $135 \mathrm{ohm}$ potentiometer in the limit controller provides 50 percent operation of a valve or damper. For those applications where the limit controller must be able to operate the valve or damper to 100 percent of its capacity, it must have either one 270 ohm potentiometer or two series-connected potentiometers with combined total resistance up to 280 ohms. If a 2 . potentiometer limit controller is used, it should be wired into the circuit so control varies over the entire resistance. 


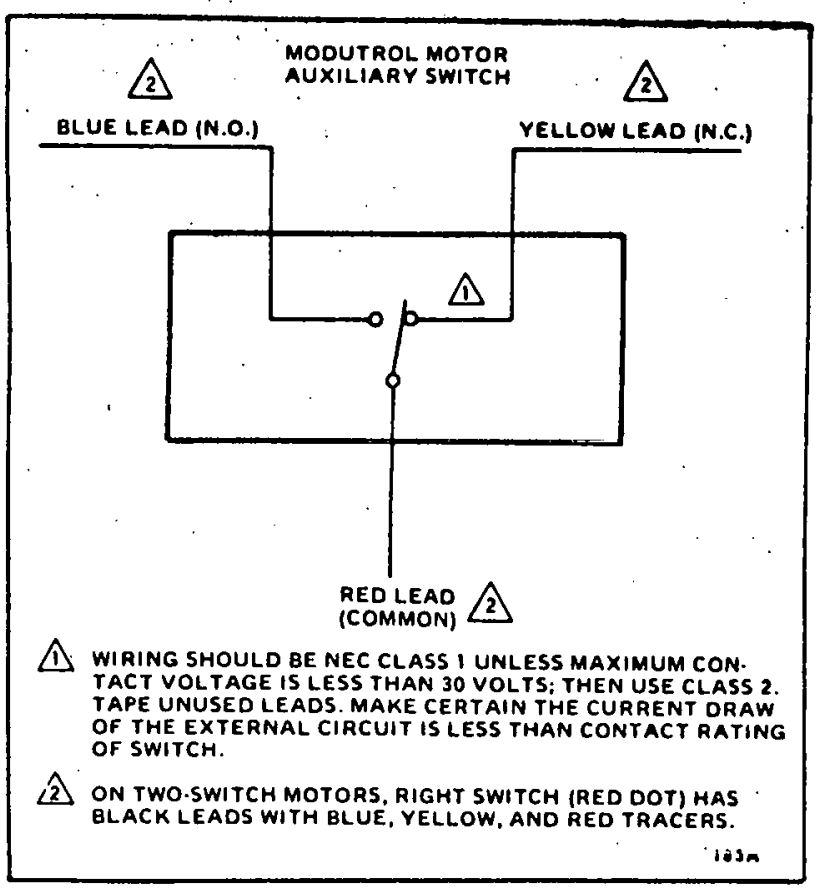

FIG. 2- AUXILIARY SWITCH SCHEMATIC.

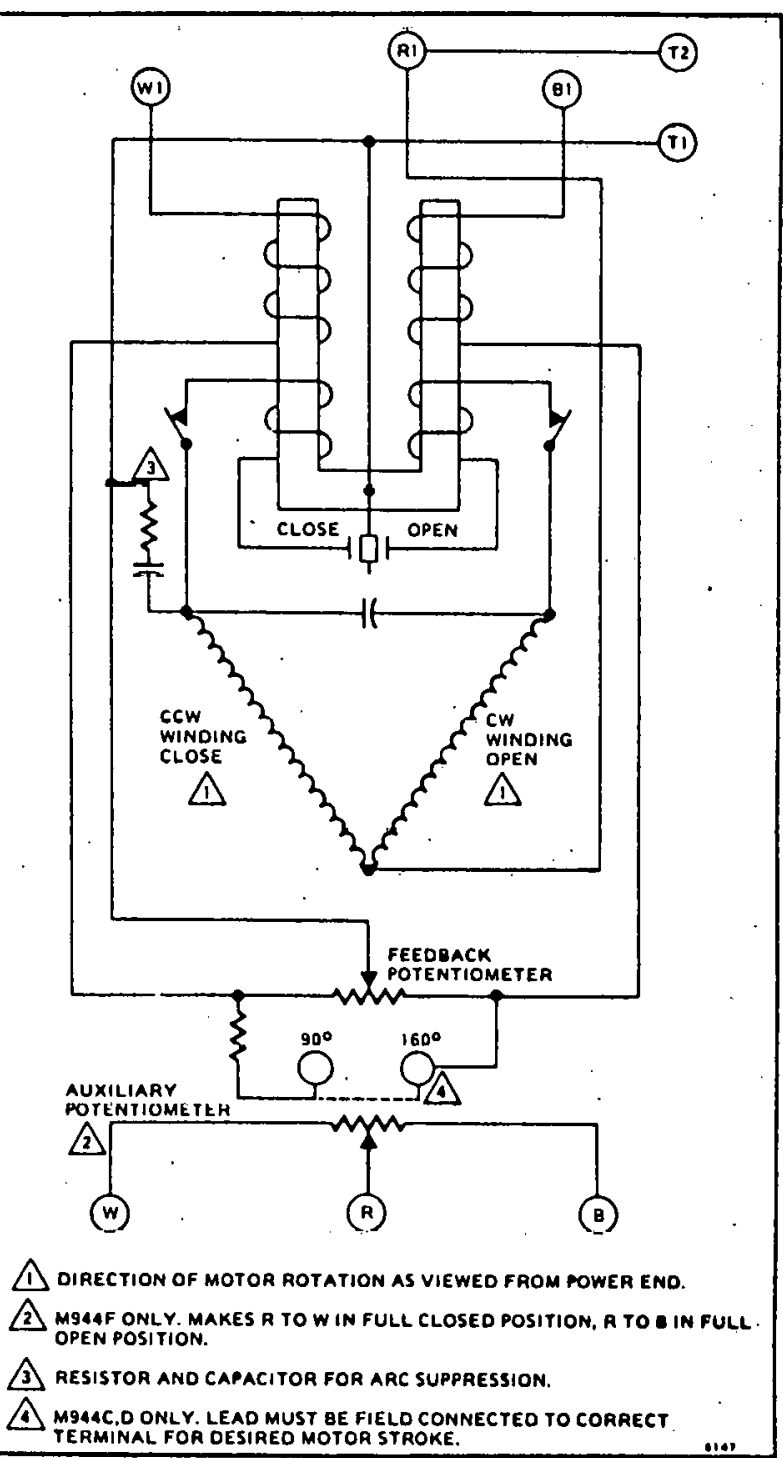

FIG. 3-M944A,C,D,F INTERNAL SCHEMATIC.
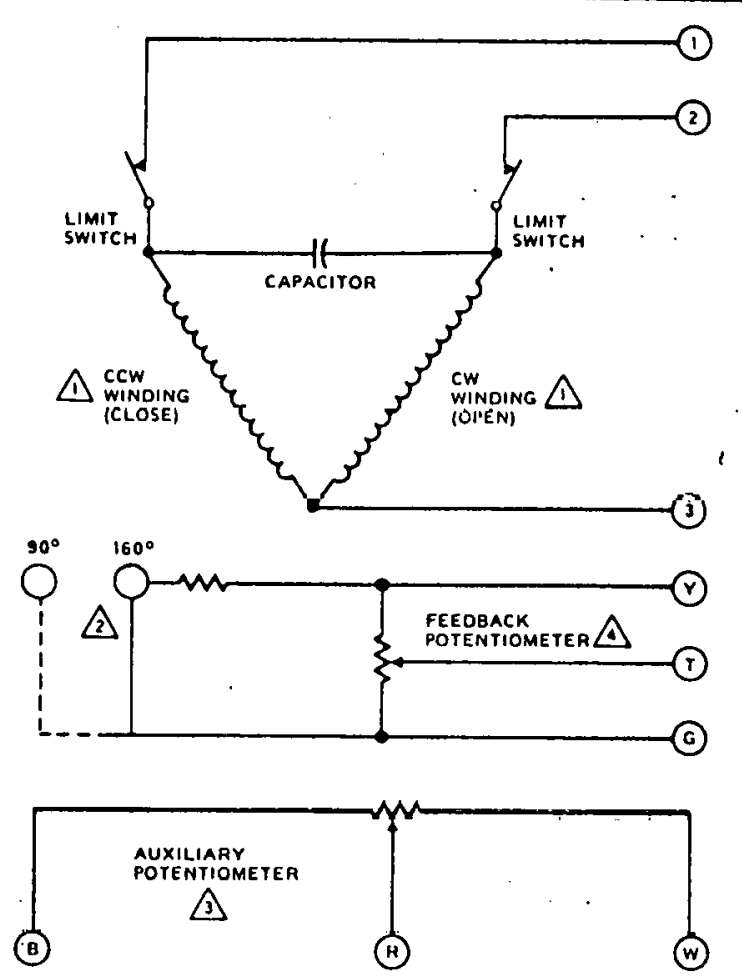

MGAAB,E.G.J, ANO L

A DIRECTION OF MOTOR ROTATION AS VIEWEO FROM POWER END.

2. MgA4E ONLY. LEAD MUST BE FIELD.CONNECTED TO CORRECT TERMINAL FOR OESIRED MOTOR STROKE.

S. AUXIL,IARY POTENTIOMETER ON MOAL! ONLY: MAKES A TO W IN FULL CLOSED POSITION, R TO B IN FULL OPEN POSITION.

A FEeOBACK POTENTIOMETER MAKES T TOG IN FULL CLOSEO POSITION. T TO Y IN FULL OPEN POSITION.

S. TERMINALS I, 2, AND 3 AAE LINE VOLTAGE ON MGAAG, L ONLY.

$463 C$

FIG. 4-M944B,E,G,J,L INTERNAL SCHEMATIC.

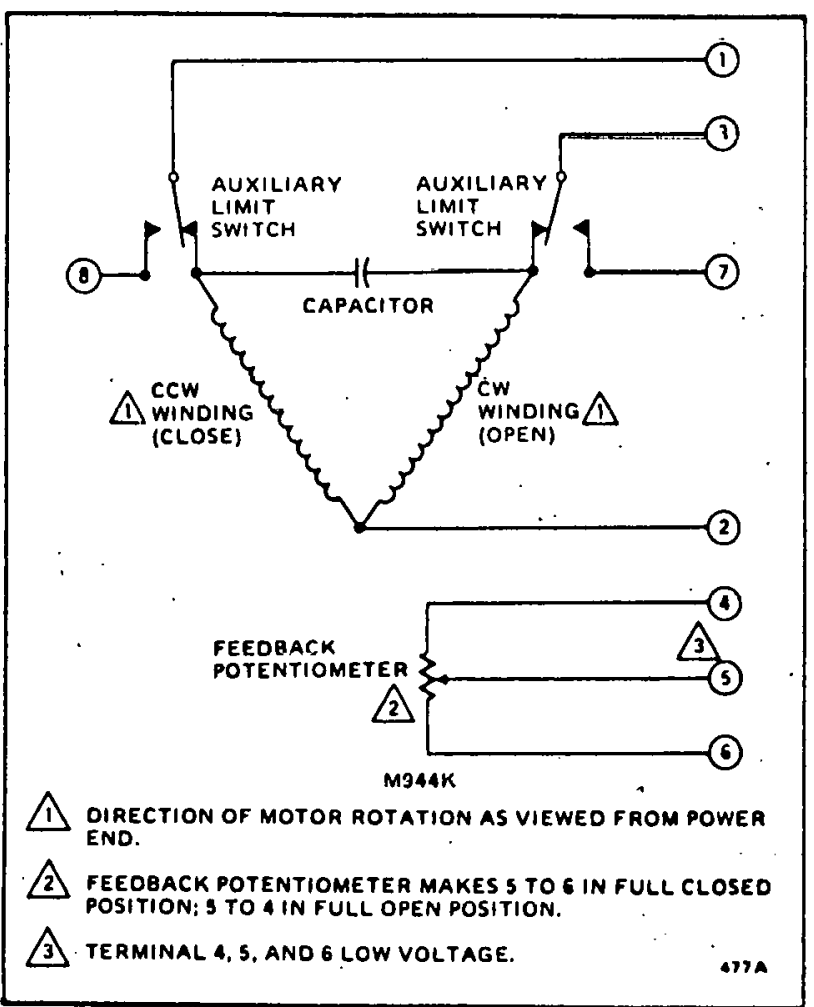

FIG. 5- M944K INTERNAL SCHEMATIC. 


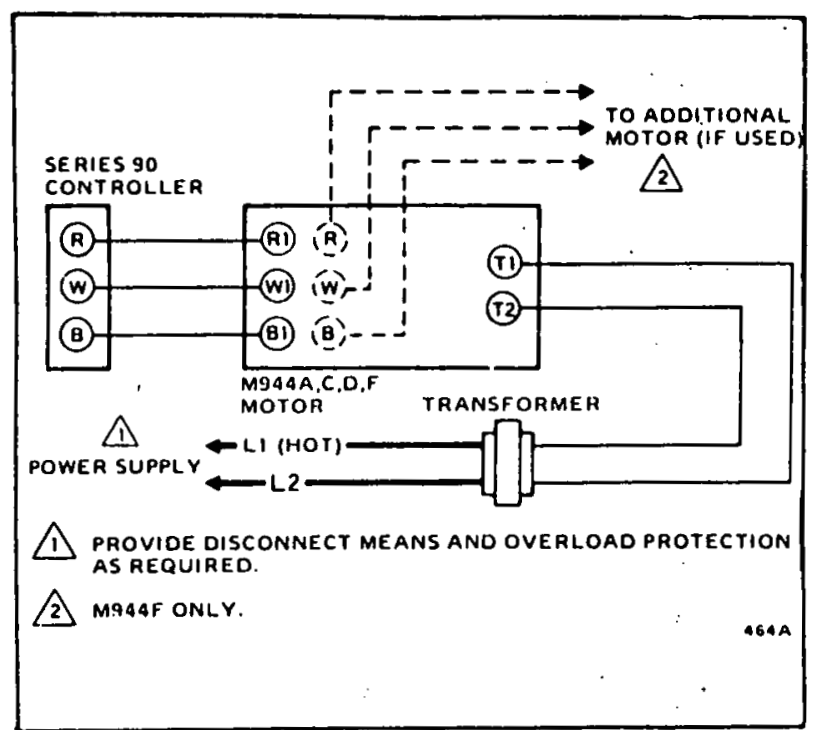

FIG. 6-M944A,C,D, OR F MODUTROL MOTOR USED WITH A SERIES 90 CONTROLLER. DOTTED I.INES SHOW CONNECTIONS TO SECOND MOTOR (M944F ONLY).

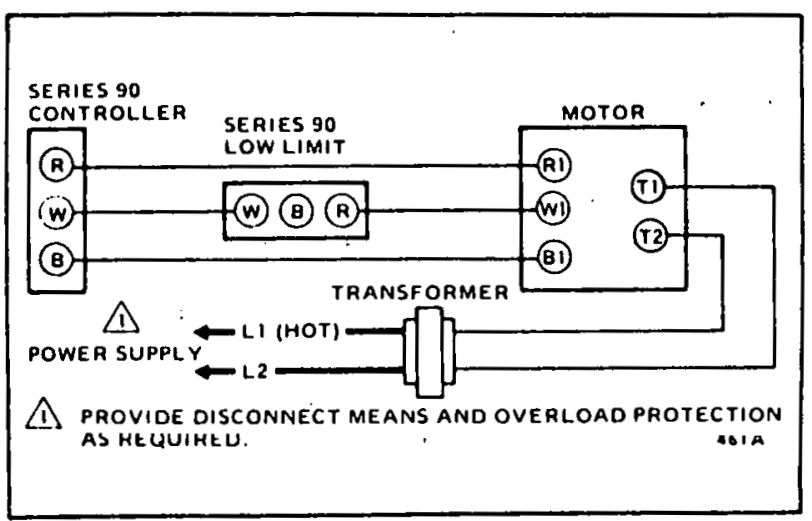

FIG. 7-M944A,C,D, OR F USED WITH MODULATING LOW LIMIT TO PREVENT DISCHARGE AIR FROM GOING BELOW DESIRED MINIMUM TEMPERATURE (MAXIMUM AUTHORITY50 PERCENT WITH 135 OHM CONTROLLER OR 100 PERCENT WITH 270 OHM CONTROLLER).

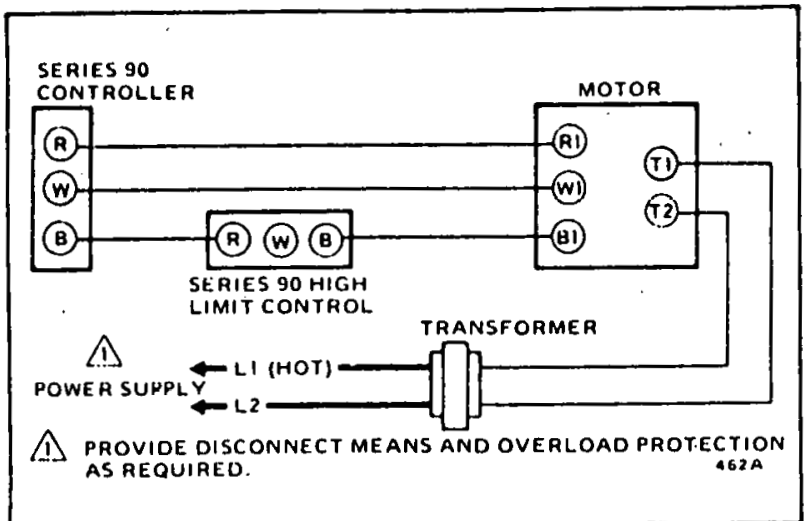

FIG. 8-M944A,C,D, OR F MOTOR USED WITH A SERIES $90^{\circ}$ CONTROLLER AND A SERIES 90 HIGH LIMIT; OFTEN USED ON CENTRAL FAN HEATING SYSTEMS TO LIMIT THE DISCHARGE AIR TEMPERATURE.

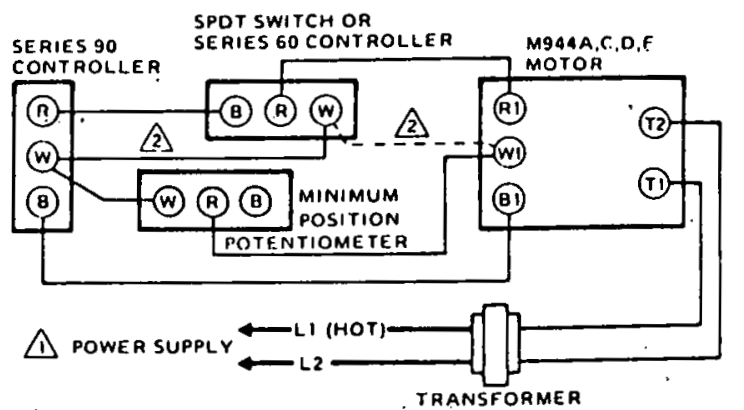

A PROVIDE DISCONNECT MEANS AND OVERLOAD PROTECTION AS REQUIRED.

2 USE SOLID LINE CONNECTION FOR POSITIVE CLOSINS TO MINIMUM POSITION. SUASTITUTE DOTTED LINE CONNECTION FOR POSITIVE FULL CLOSURE.

$$
\text { 4GSA }
$$

FIG. 9-M944A,C,D, OR F MOTOR USED WITH A SERIES 90 CONTROLLER, A MANUAL MINI. MUM POSITION POTENTIOMETER, AND AN SPDT SWITCH FOR 2-POSITION HIGH LIMIT CONTROL.

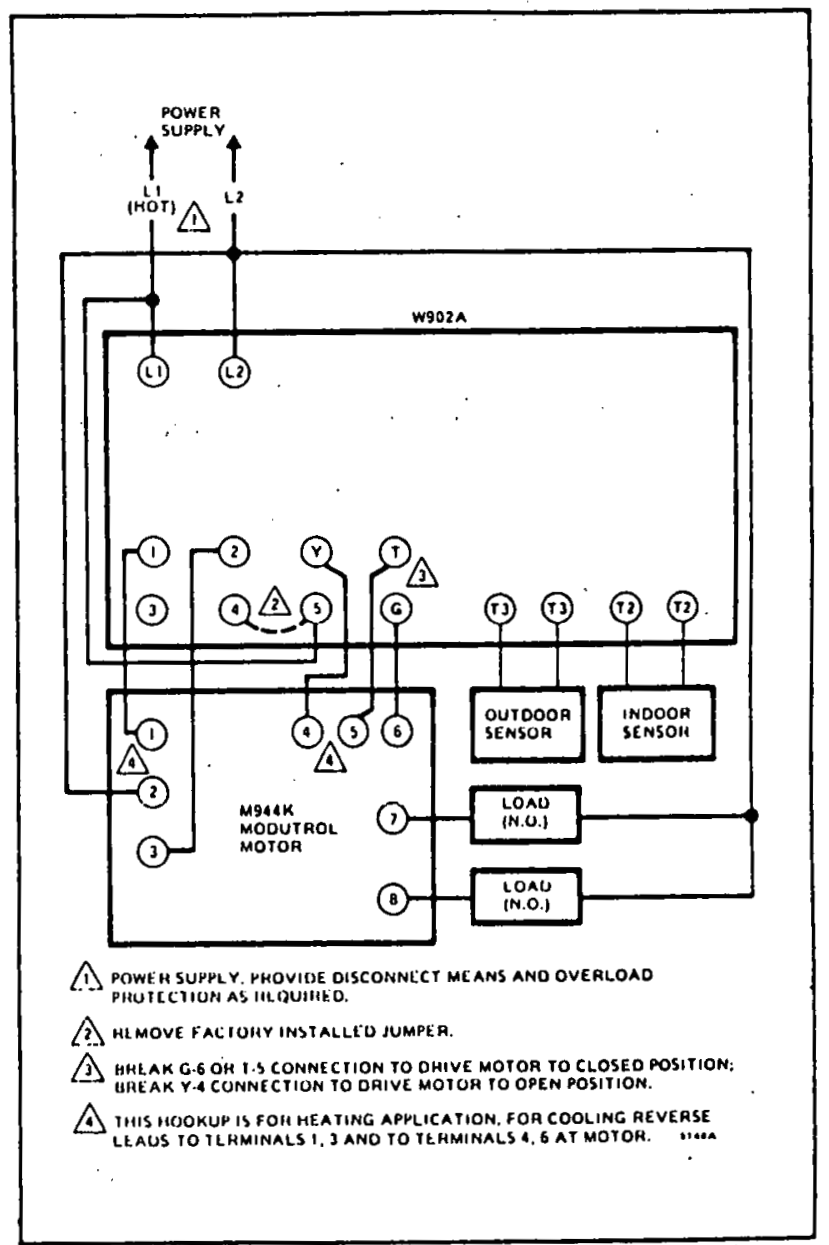

FIG. 10-CONNECTING M944K TO W902 RESET CONTROL. 


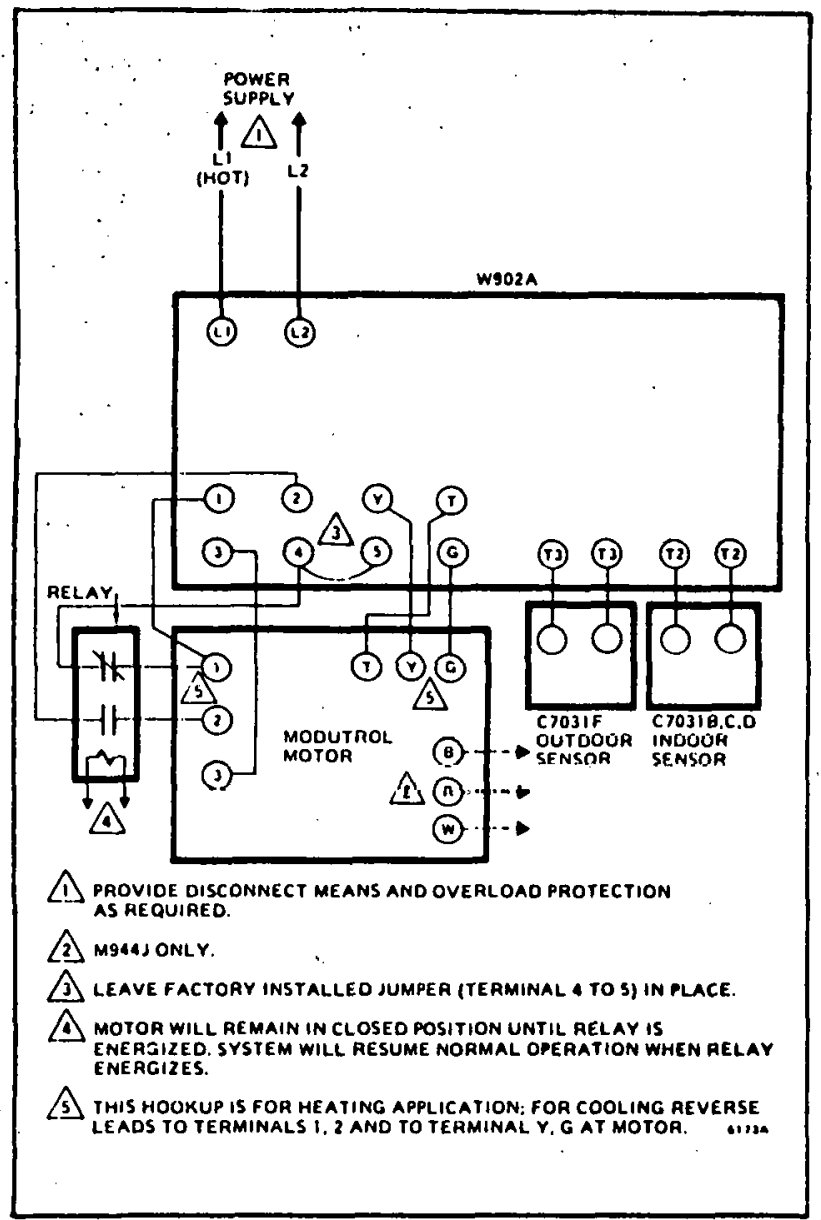

FIG. 11-M944B,E, OR J USED WITH W902 RESET CONTROL. DOTTED LINES SHOW CON. NECTIONS TO SECOND MOTOR (M944J ONLY).

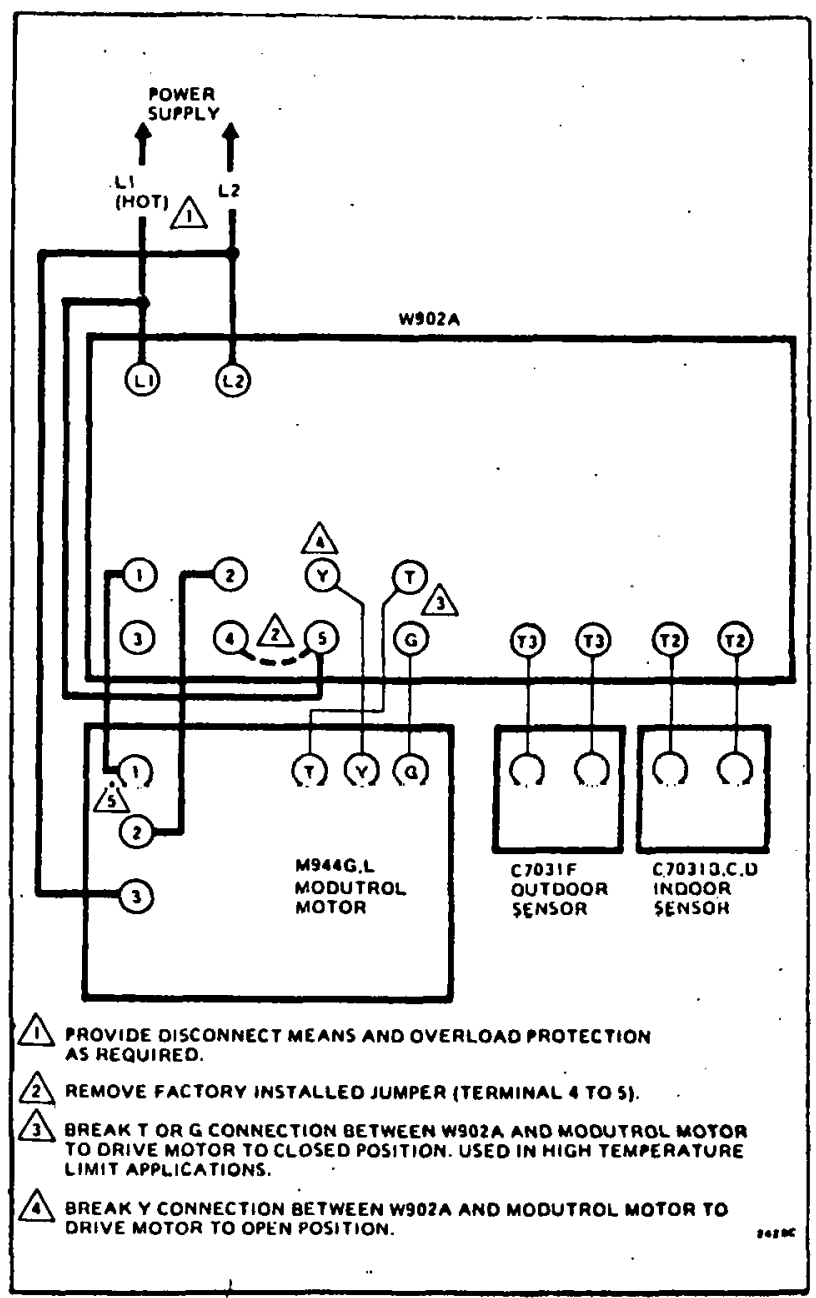

FIG. 12-CONNECTING M944G,L TO W902 RESET CONTROL.

\section{SETTINGS AND ADJUSTMENTS}

\section{STROKE ADJUSTMENT}

\section{(DUAL STROKE MOTORS M944C,D,E, AND L)}

Changing the position of the limit arms that actuate the limit switches adjusts the motor stroke. Use the following procedure to adjust the stroke to 90 or 160 degrees.

1. Run motor to approximately midstroke (motor must remain there while making adjustments). Remove the cover from the auxiliary end of the motor by taking out the 4 screws securing it. On the M944D and E, be careful not to lose the small spring and washers around the motor shaft. They hold the switch cams against the driving dogs. Remove the switch cams from the M944D and $\mathbf{E}$.
NOTE (for motors with auxiliary switches): The switch cams are color-coded to insure they are driving the correct switch. The inner cam (color-coded blue) drives the loft ewitoh (also color eoded blue). The outer cam (color-coded red) drives the right switch. When replacing the cam in the motor, make certain the color code of the switch matches the color code of the driving cam.

2. Loosen the 2 screws in the limit arm hub (Fig. 13). Set the arms at either extreme of their travel. With both arms up, the stroke will be 160 degrees; with both arms down, the stroke will be 90 degrees. Retighten both screws.

3. Connect the terminal board lead to the proper terminal (160 or 90).

Both limit arms and lead must be set for the same
stroke $(90$ or 160$)$ or the motor will not control
accurately.


4. Replace the switch cams and the spring and washers on M944D,E.

NOTE: When reinstalling cam, make certain the driving dogs engage the keyway slots on the limit arm assembly. Replace the motor cover and secure with 4 screws.

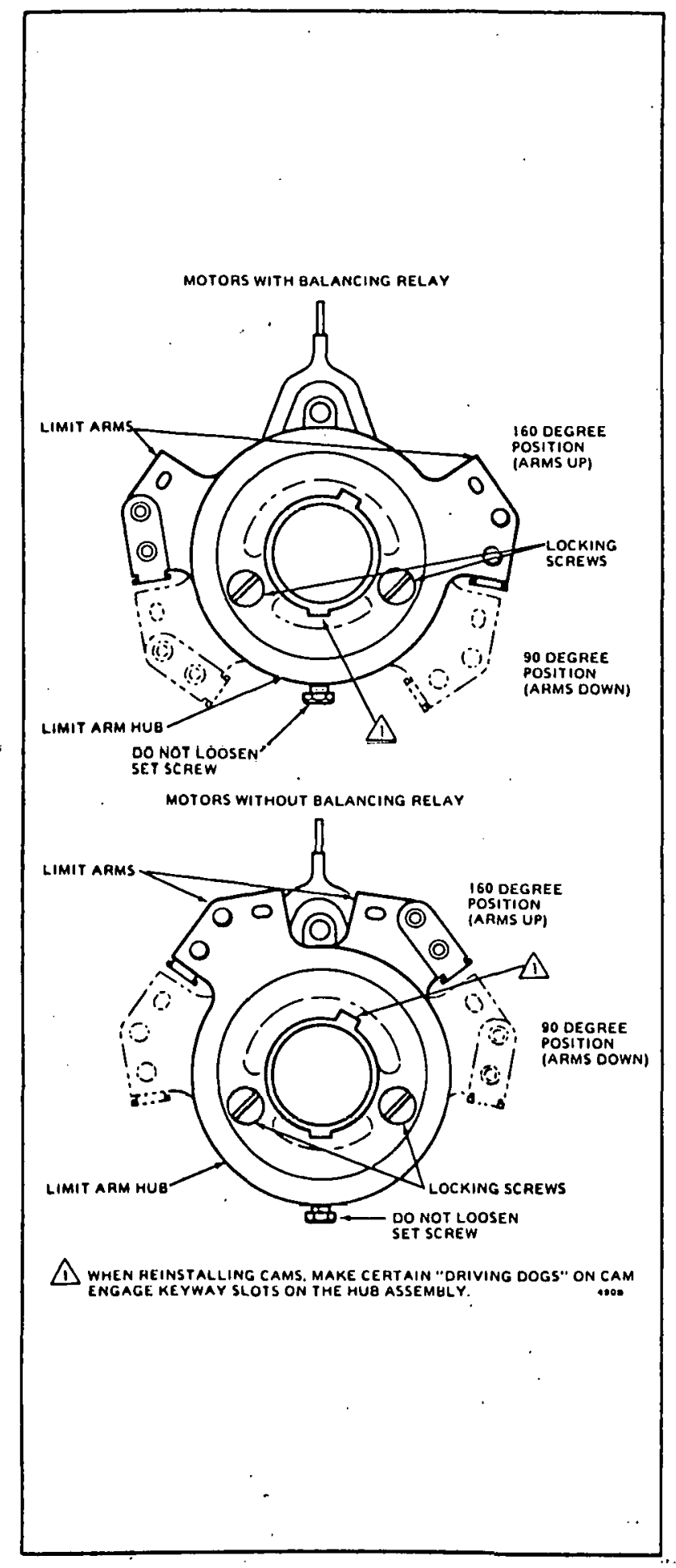

FIG. 13-CHANGE THE PÓSITIONS OF THE LIMIT ARMS TO ADJUST THE MOTOR STROKE.

\section{AUXILIARY SWITCH ADJUSTMEN, (M944D,E ONLY)}

The auxiliary switches in the M944 are operated by cams on the motor shaft. Each switch is operated by a separate set of cams; the left switch and cams are color-coded blue, and the right switch and cams are color-coded red. The switch makes red to blue when its cam roller moves to the upper level of the operational cam and makes red to yellow when the cam roller moves to the lower level. The differential cam provides an intermediate level; it can be used to increase differential between the switch make and break points.

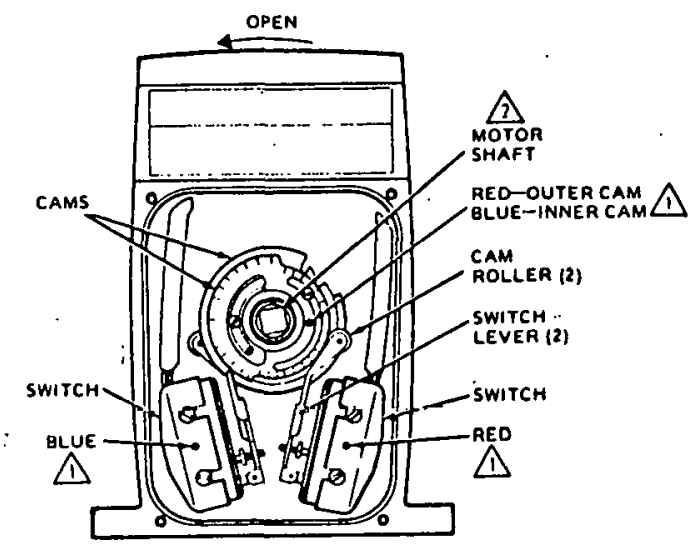

$\triangle$ COLOR CODING DOT. 2. MOTOR SHOWN AT CLOSED POSITION AS VIEWEO FROM
AUXILIARY END.
FIG. 14-LOCATION OF INTERNAL AUXILIARY SWITCHES AND SWITCH CAMS IN M944 MODUTROL MOTORS.

\section{APPROXIMATE ADJUSTMENT}

(Does not require running the motor.)

1. Motor must be in the full closed position.

2. Remove auxiliary end cover by removing the 4 screws securing it to the motor.

3. Remove spring and washers on motor shaft.

4. Push back right cam roller and remove outer cam. Note color coding dots.

5. Adjust left switch (inner cam) first (Fig. 15). 


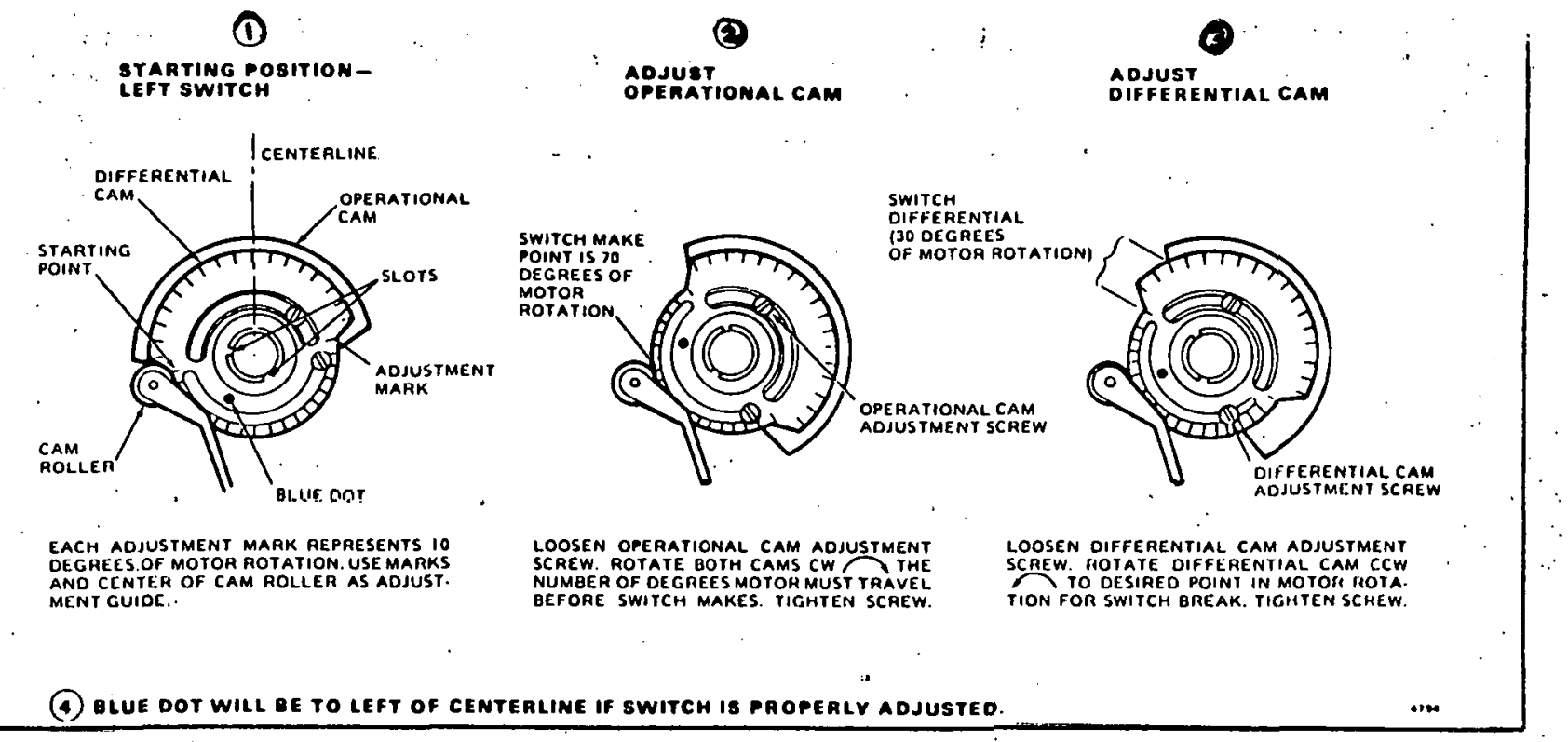

FIG. 15-ADJUST MAKE AND BREAK POINTS OF LEFT AUXILIARY SWITCH.

6. Put right switch cams on motor shaft and adjust right switch (Fig. 16).

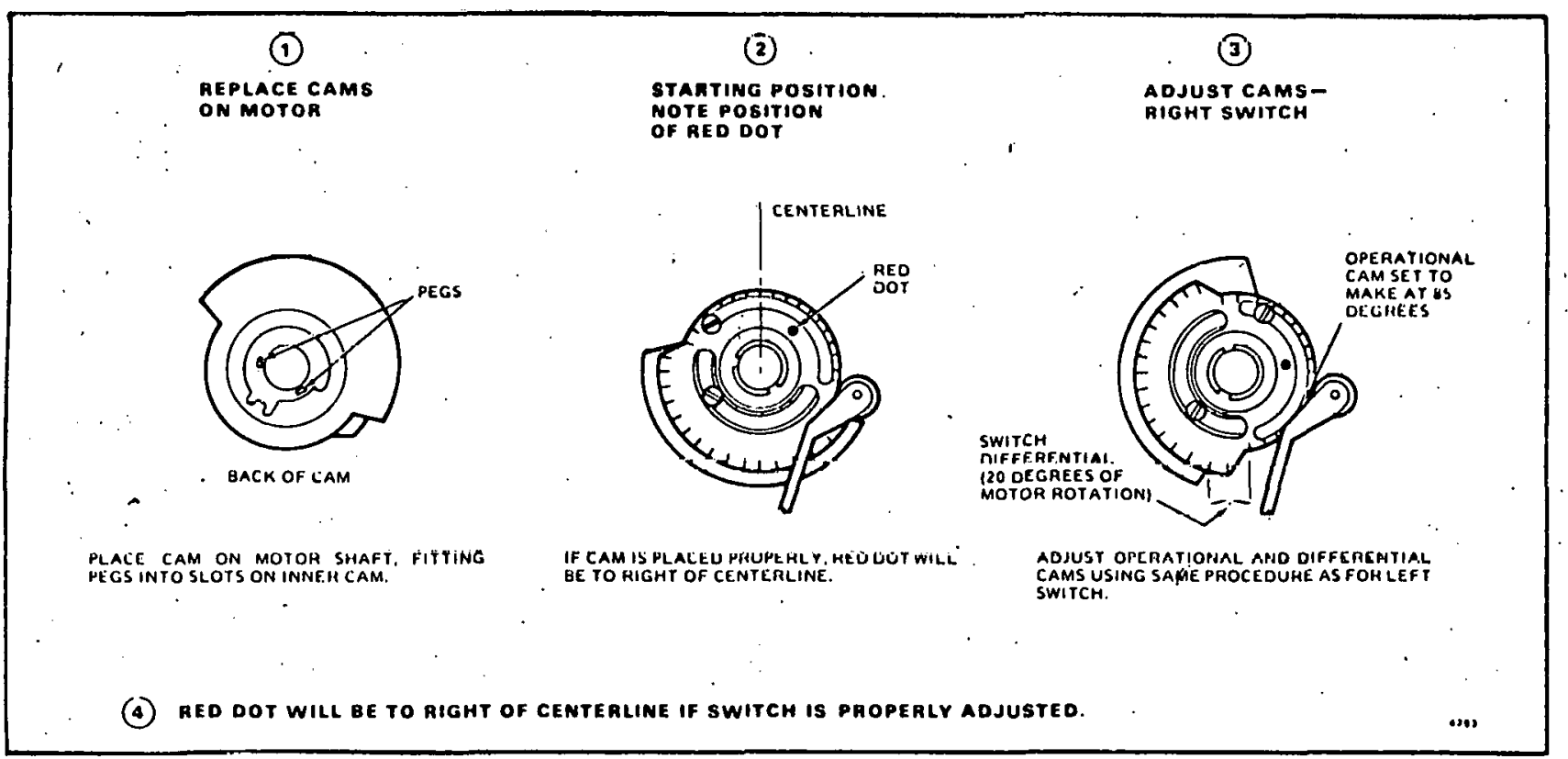

FIG. 16-ADJUST MAKE AND BREAK POINTS OF RIGHT AUXILIAÁY SWITCH.

7. After switches are adjusted, replace spring and washers on motor shaft and replace the auxiliary end cover.

\section{EXACT ADJUSTMENT}

(Requires running the motor.)

Connect a manual potentiometer to the motor in place of the regular controller and run the motor to the de. sired position for switch make. Set the switch cam and then run the motor back to desired switch break point and set differential cam.

\section{(x)}

Do not turn the motor shaft by hand or with a wrench as damage to the gear train will result.

\section{M944K AUXILIARY SWITCHES}

The auxiliary switches in the M944K are not adjust. able. They are spdt switches which function both as auxiliary switches and as limits on motor rotation. When the motor reaches the full open position, the auxiliary side of tho switohes makes to powor auxiliary equipment. When the motor begins to close, these switches break and the limit side of the switches remakes to supply power to the motor windings. 


\section{SERIES 90 CIRCUIT}

The 2 potentiometers, one in the controller and one in the motor, along with the balancing relay form a bridge circuit. As long as the value of the controlled medium remains at the controller set point, the circuit is balanced (equal current flowing through each half of the balancing relay), and the motor does not run.

When the value of the controlled medium changes, the potentiometer wiper in the controller is moved. This unbalances the circuit and more current flows through one-half of the balancing relay. The relay closes and the motor runs in the direction necessary to correct the change in temperature or pressure. As the motor runs, the feedback potentiometer moves to rebalance the circuit and stop the motor.

\section{SERIES 70 CIRCUIT}

When the M944 is used with an electronic panel, the operation is similar to that described above. In this application, however, the temperature is sensed by a resistance element. With a change in temperature, the resistance of the element changes and unbalances a circuit that actuates the electronic relay. This, in turn, runs the motor, which moves the feedback po. tentiometer and rebalances the circuit.

\section{CHECKOUT}

After installation and linkage adjustment, check the entire motor and control hookup to prove that -

-the motor operates the damper or valve properly.

- the motor responds properly to the controller.

Inspect the motor, linkage and valve or damper to see that all mechanical connections are correct and secure. In damper installations, the pushrod should not extend more than a few inches past the ball joints. Check to see that there is adequate clearance for the linkage to move through its stroke without binding or striking other objects.

M944 motors are shipped in the fully closed position (the limit of counterclockwise rotation as viewed from the power end of the motor).

To check operation of motors with integral balance relay, jumper $\mathrm{Rl}$ to $\mathrm{Wl}$ to close, or $\mathrm{Rl}$ to $\mathrm{Bl}$ to open, the motor. Check operation of motors without integral balance relay by jumpering appropriate terminals on the remote balance relay. If the motor is used with an elec. tronic relay, follow the instructions provided with the relay.

To reverse the direction of motor rotation, reverse the wires at terminals $\mathrm{Bl}$ and $\mathrm{Wl}$ on M944A,C,D, and $F$; terminals 1 and 2 and terminals $Y$ and $G$ on M944B,E, $\mathrm{G}, \mathrm{J}$, and $\mathrm{L}$ motors. On M944K motors, reverse the wires at terminals 1 and 3 and terminals 4 and 6 . The wires may be reversed either at the motor or at the panel.

To check system operation, adjust the set point of the controller above and below the ambient value and make sure the motor and valve or damper operate as desired. Return controller to desired setting before leaving job. 
THE Q601 VALVE LINKAGE IS USED TO CONNECT A MODUTROL MOTOR TO A WATER OR STEAM VALVE.

$\square$ It is applicable to either two or three way valves in modulating or two position service.

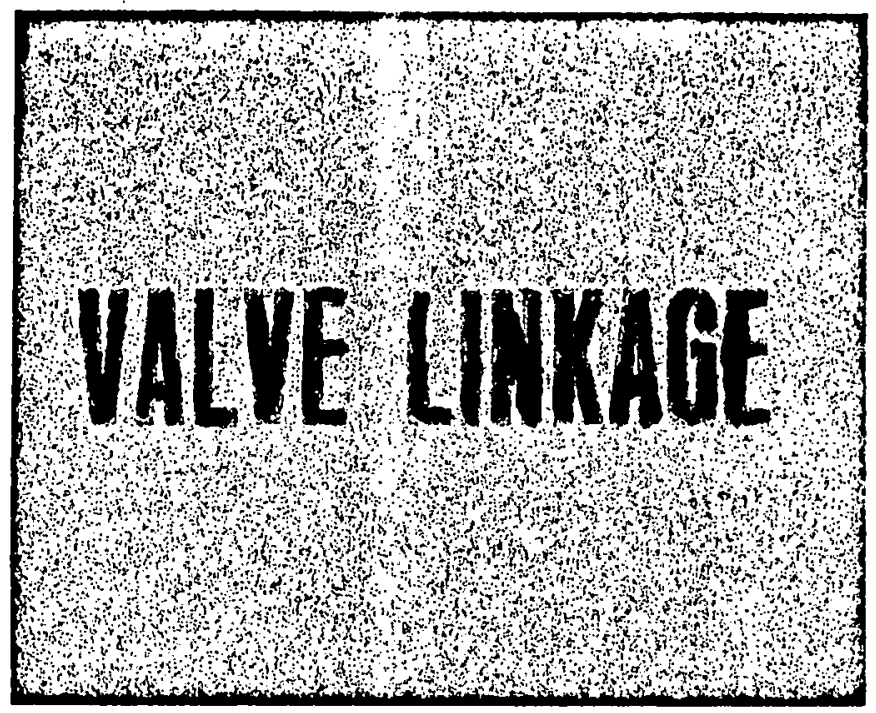

$\square$ The linkage mounts directly on the valve bonnet and the motor mounts on the linkage.

in Easy-to-read valve position indicator.

$\square$ Simple lift adjustment.

$\square$ Strain relief permits tightest possible closeoff without excessive strain on the motor.

$\square$ Easy mounting and valve connection.

$\square$ Two bracket diameters make linkages adaptable to many valve bodies.

H.A.

REV. $5-74(.034)$
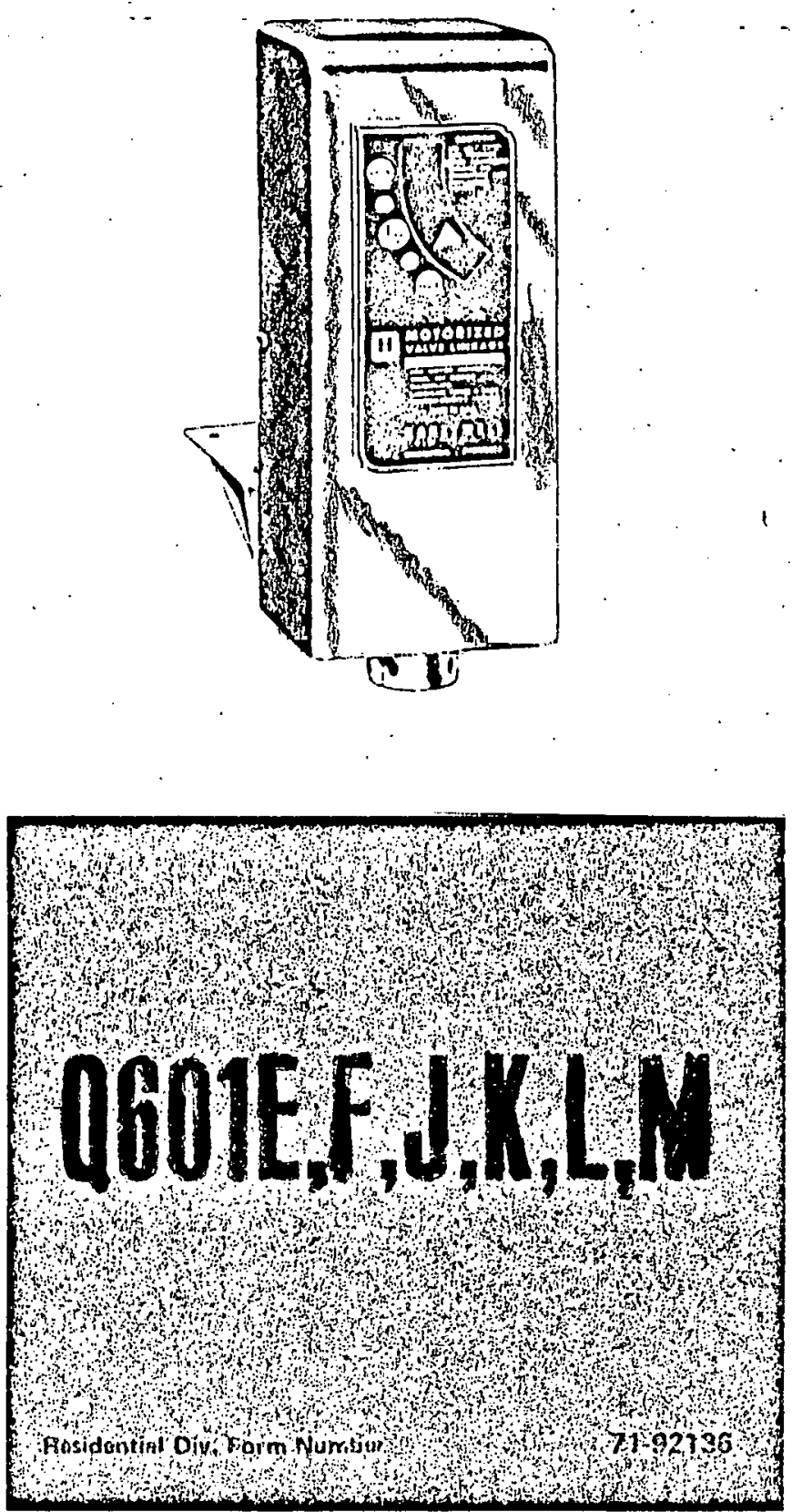
TRADELINE MODELS

Tradeline models are selected and packaged for ease of stocking, ease of handling, and maximum replacement value. Tradeline model specifications are the same as those for standard modcls cxcept as follows:

TRADELINE MODELS AVAILABLE: Q601M nonTRADELINE FEATURES: Special Tradeline pack adjustable valve linkage. with cross reference label and special Tradeline instructions.

STANDARD MODELS

TABLE I

\begin{tabular}{|c|c|c|c|c|c|c|c|}
\hline MODEL & $\begin{array}{c}\text { STRADN } \\
\text { RELIEF } \\
\text { SPRDNG } \\
\text { TENSION } \\
\text { (LB) }\end{array}$ & $\begin{array}{c}\text { LIFT } \\
\text { SLOT } \\
\text { ADJUSTMENT } \\
\text { (IN) }\end{array}$ & $\begin{array}{c}\text { BONNET } \\
\text { CONNECTION }\end{array}$ & $\begin{array}{l}\text { BONNET } \\
\text { SIZE } \\
\text { (IN) }\end{array}$ & $\begin{array}{c}\text { STEM } \\
\text { CONNECTION } \\
\text { TYPE }\end{array}$ & $\begin{array}{l}\text { ANTI-SPIN } \\
\text { MECHANISM } \\
\text { INCLUDED }\end{array}$ & $\begin{array}{l}\text { LINKAGE } \\
\text { REPLACED }\end{array}$ \\
\hline Q601E & 160 & $3 / 8$ to $1-1 / 2$ & Setscrews & $1-7 / 8$ & button \& clamp & yes & - \\
\hline$Q 601 F$ & 80 & $3 / 8$ to $2-1 / 2$ & Setscrews & $1-7 / 8$ & button \& clauns & yes & $\mathrm{Q601H}$ \\
\hline $\mathrm{Q} 601 \mathrm{~J}$ & 160 & $3 / 4 \mathrm{fixcd}^{\mathrm{h}}$ & Setscrews & $1-3 / 8$ & button \& clamp & no & - \\
\hline $\mathrm{Q} 601 \mathrm{~K}$ & 160 & $3 / 8$ to $1-1 / 2$ & Setscrews & $1-3 / 8$ & button \& clamp & yes & Q601D \\
\hline Q601L & 80 & $3 / 8$ to $1-1 / 2$ & Setscrews & $1-3 / 8$ & button \& clamp & yes & Q601G \\
\hline $\mathrm{Q601M}$ & 80 & $3 / 4$ fixed $^{2}$ & Setscrews & $1-3 / 8$ & button \& clamp & no & Q455G \\
\hline
\end{tabular}

$\mathrm{a}_{\text {Heat-Cool sequenced linkage. }}$

MODELS VALVE-LINKAGE-MOTOR COMBINATIONS

TABLE II-SPRING RETURN MOTORS: 2 POSITION-M445, M845; MODULATING-M945-

\begin{tabular}{l|c|c|c|c}
\hline VALVE & TYPE & CONNECTIONS & PIPE SIZE (IN) & LINKAGE \\
\hline V5011A & 2 way & screwed & $1 / 2,3 / 4,1,1-1 / 4,1-1 / 2$, & Q601L \\
\hline V5011A & 2 way & flanged & $2-1 / 2,3,3$ & Q601L \\
\hline V5047A & 2 way & screwed & $1,1-1 / 4,1-1 / 2,2$ & Q601L \\
\hline V5013A & $\begin{array}{c}\text { 3way } \\
\text { nixing }\end{array}$ & screwed & $1 / 2,3 / 4,1,1-1 / 4,1-1 / 2,2$ & Q601L \\
\hline
\end{tabular}

TABLE III-NON.SPRING RETURN MOTORS: 2 POSITION-M644; MODULATING-M944-

\begin{tabular}{|c|c|c|c|c|}
\hline VALVE & TYPE & CONNECTIONS & PIPE SIZE (IN) & LNNAAGE \\
\hline $\mathrm{V} 5011 \mathrm{~A}, \mathrm{C}$ & 2 way & Screwed & $1 / 2,3 / 4,1,1-1 / 4,1-1 / 2,2,2-1 / 2,3$ & $Q 601 K$ \\
\hline V5011A & 2 way & Flanged & $2-1 / 2,3$ & Q601K \\
\hline $\mathrm{V} 5011 \mathrm{~A}, \mathrm{~B}$ & 2 way & Flanged & $4,5,6$ & Q601E \\
\hline V5047A & 2 way & Screwed & $1,1-1 / 4,1-1 / 2,2$ & Q601K \\
\hline V5051A & 2 way & Flanged & $2-1 / 2,3,4,5,6$ & Q601K \\
\hline V5013A & 3 way, mixing & Screwed & $1 / 2,3 / 4,1,1-1 / 4,1-1 / 2,2$ & Q601K \\
\hline V5013B & 3 way, mixing & Flanged & $2-1 / 2,3$ & Q001K \\
\hline V5013B & 3 way, mixing & Flanged & $4,5,6$ & Q601E \\
\hline V5013C & $\begin{array}{l}\text { 3 way, } \\
\text { diverting }\end{array}$ & Elanged & $2-1 / 2,3$ & $Q 601 K$ \\
\hline V5013C & $\begin{array}{l}3 \text { way, } \\
\text { diverting }\end{array}$ & Flanged & $4,5,6$ & Q601E \\
\hline
\end{tabular}

\section{ORDERING INIFORMATION}

WHEN ORDERING REFER TO THE TRADELINE CATALOG OR PRICE SHEETS FOR COMPLETE ORDERING SPECIFICATION NUMBER, OR ...

SPECIFY-

1. MODEL NUMBER (VALVE AND MOTOR MUST BE ORDERED SEPARATELYI.

2. O601M TRADELINE. IF DESIRED.
OROER FROM-

1. YOUR USUAL SOURCE, OR

2. HONEYWELL

1885 DOUGLAS DRIVE NORTH

MINNEAPOLIS, MINNESOTA 55422

IIN CANADA-HONEYWELL CONTROLS LIMITED 740 ELLESMERE ROAD SCARBOROUGH, ONTARIO)

INTERNATIONAL SALES AND SERVICE OFFICES IN ALL PRINCIPAL CITIES OF THE WORLD. 
LISTS FOR COMMONLY USED VALVES (INCHES)

TABLE IV-

\begin{tabular}{|c|c|c|c|c|c|c|c|c|c|c|c|}
\hline VALVE & \multicolumn{11}{|c|}{ VALVE SIZEa } \\
\hline MODEL NO. & $1 / 2$ IN. & $3 / 4 \mathrm{IN}$. & $1 \mathrm{IN}$. & $1-1 / 4 \mathrm{IN}$. & $1-1 / 2 \mathrm{IN}$. & 2 IN. & $2-1 / 2 \mathrm{IN}$. & $3 \mathrm{IN}$. & $4 \mathrm{IN}$. & $5 \mathrm{IN}$. & 6 IN. \\
\hline $\mathrm{V} 5011 \mathrm{~A}$ & $3 / 4$ & $3 / 4$ & $3 / 4$ & $3 / 4$ & $3 / 4$ & $3 / 4$ & $3 / 4$ & $3 / 4$ & $1-1 / 2$ & $1-1 / 2$ & $1-1 / 2$ \\
\hline V5013A & $3 / 4$ & $3 / 4$ & $3 / 4$ & $3 / 4$ & $3 / 4$ & $3 / 4$ & -1 & $=$ & 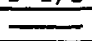 & & \\
\hline V5013B & $=$ & $=$ & $=$ & - & $=$ & $=$ & $3 / 4$ & $3 / 4$ & $1-1 / 2$ & $1-1 / 2$ & $1-1 / 2$ \\
\hline V5013C & $=$ & $=$ & $\bar{T}$ & $=$ & $=$ & $=$ & $3 / 4$ & $3 / 4$ & $1-1 / 2$ & $1-1 / 2$ & $1-1 / 2$ \\
\hline $\mathrm{V} 5047 \mathrm{~A}$ & 二 & $=$ & $9 / 16$ & $9 / 16$ & $9 / 16$ & $3 / 4$ & $=$ & - & $-\infty$ & - & \\
\hline V5051A & $\overline{-}$ & $=$ & $=$ & $=$ & - & - & $1-1 / 2$ & $1-1 / 2$ & $1-1 / 2$ & $1-1 / 2$ & $1-1 / 2$ \\
\hline
\end{tabular}

aWhere no lift values are given, either the valve is unavailable in that size or using this valve size in motordriven assembly is not recommended.

\section{DIMENSIONS}

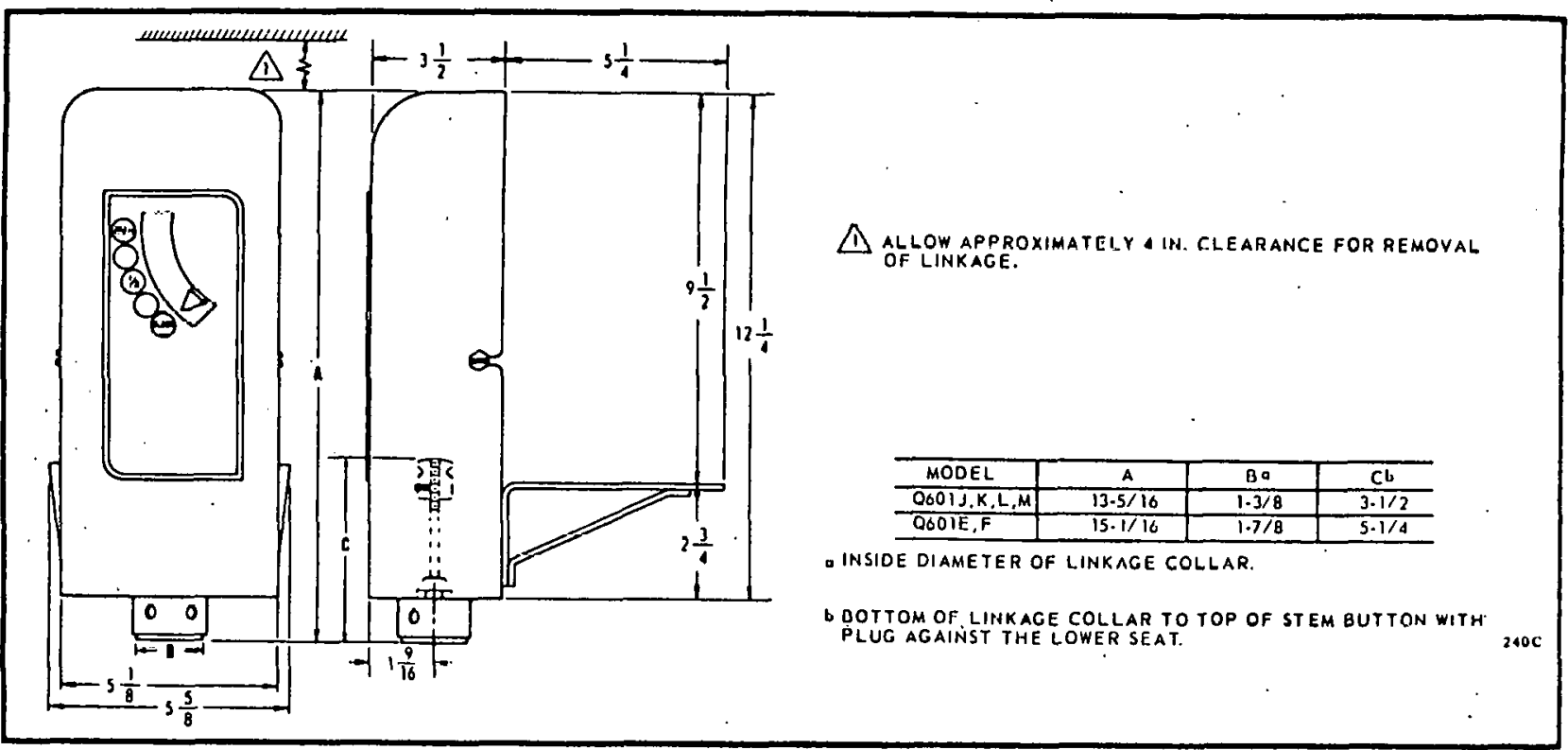

FIG. 1-0601 LINKAGES INSTALLATION WITH DIMENSIONS IN INCHES.

\section{INSTIALLATION}

IMPORTANT

1. Installer must be a trained and experienced servlceniaul.

2. Perform a complete checkout when installation is complete.

\section{LOCATION}

Select a location that allows ample clearance for adjustment and maintenance.

Mount the motor with the shaft horizontal to keep the gear train properly lubricated. Allow at least four inches above the linkage to remove the valve assembly for maintenance.

\section{MOUNTING THE MOTOR}

1. Hold the crank arm and connector link as shown in Fig. 2 (turn arm 160 degrees for normally open motors).

2. Slide the motor toward crank arm slot until motor shaft properly engages the crank arm. The key on the crank arm must fit in the keyway on the motor shaft.

3. Tighten the clamp screw.

4. Bolt motor to bracket with the four bolts provided.

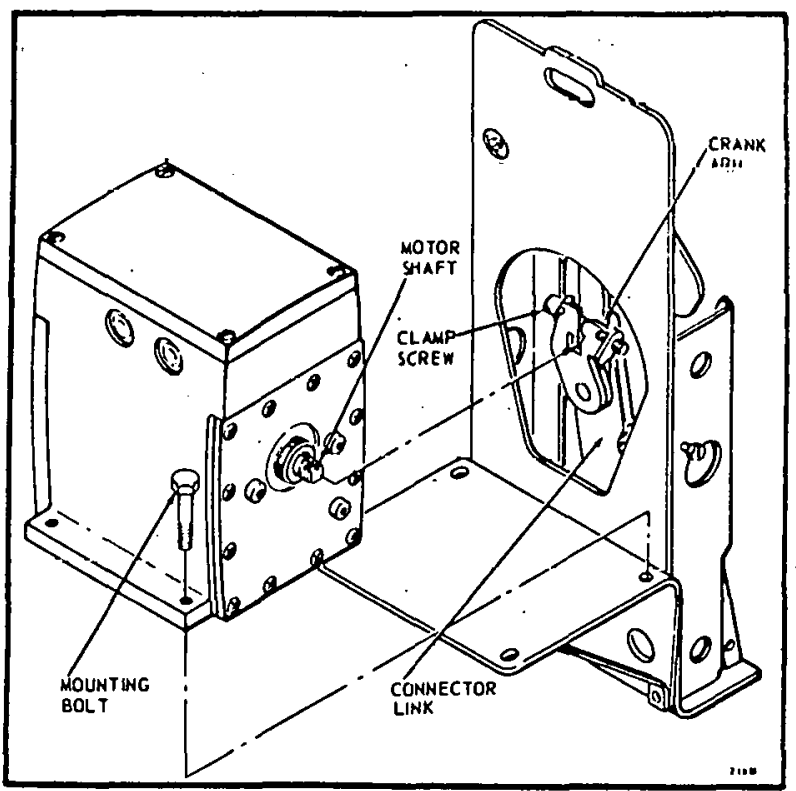

FIG. 2-MOUNTING THE MOTOR ON O601 VALVE LINKAGE. 


\section{MOUNT MOTOR AND LINKAGE ON VALVE}

\section{SETSCREW BONNET CONNECTION}

1. Remove the button clamp screw.

2. Loosen screws, fit collar over valve bonnet, and tighten screws.

3. Loosen adjustment screw locknut.

4. Push valve stem to bottom of stroke for normally closed installation (closed to port B on three-way valve).

Push valve stem totop of stroke for a normally open installation (open to port B on three-way valve).

5. Turn adjustment screw and align stem button clamp with groove in stem button.

6. Fit stem button into clamp, line up anti-spin device (when fitted), and replace and tighten the screw.

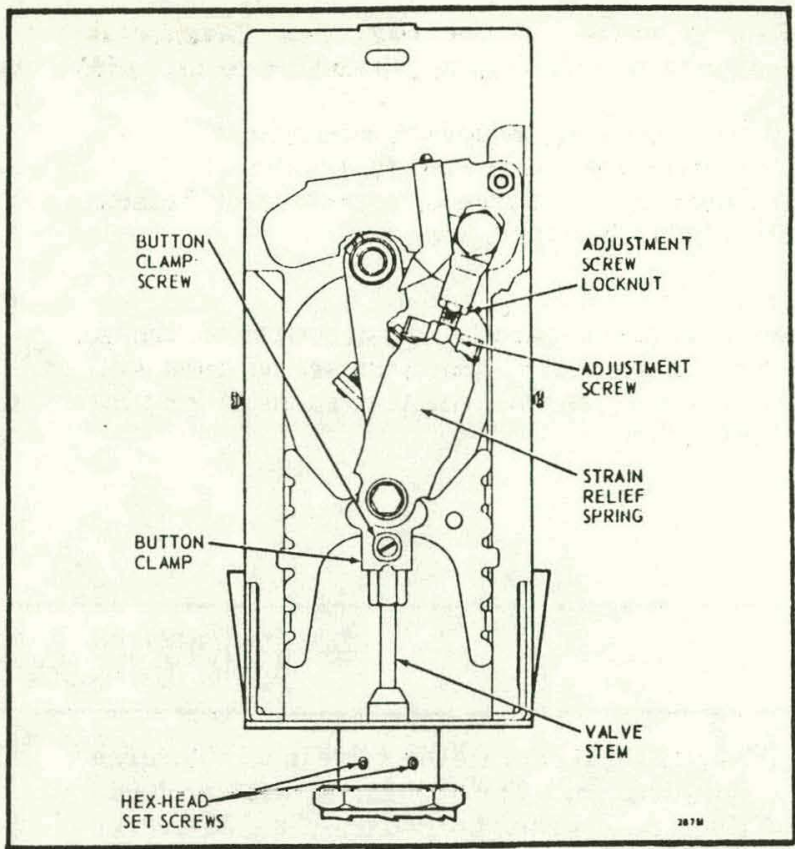

FIG. 3-MOUNTING THE Q601 LINKAGE AND MOTOR ON THE VALVE.

\section{ADJUSTMIENTS}

\section{TWO-WAY VALVES}

1. On Q601E, F, K, L only, set the lift adjustment equal to the rated lift of the valve (Table IV).

2. For all models, with valve and motor closed, loosen the locknut and turn the adjusting screw down until top of washer is even with pointer. This puts tension on valve in closed position.

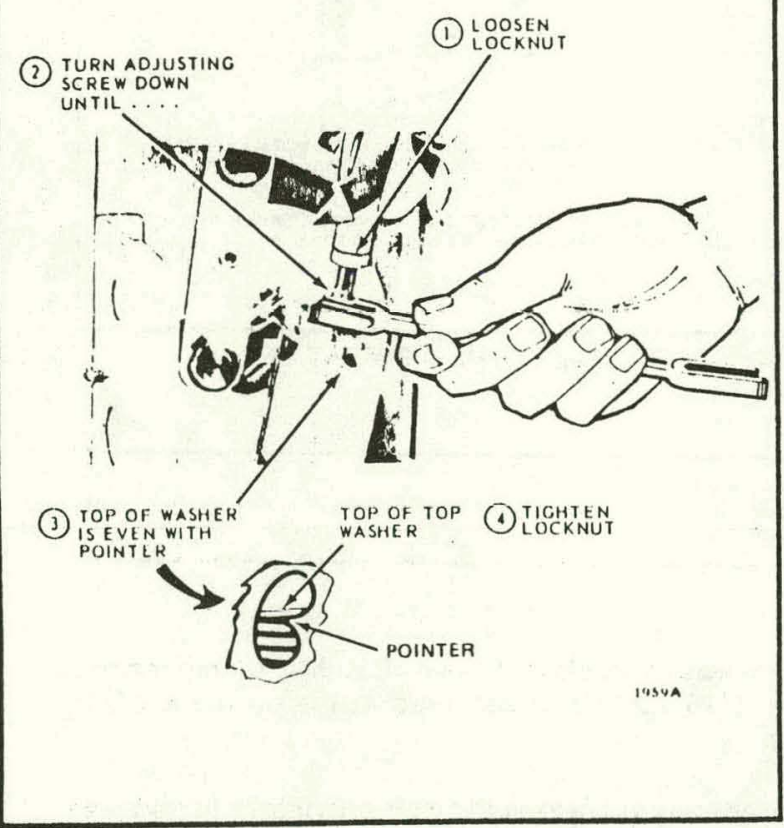

FIG. 4-TWO-WAY VALVE ADJUSTMENT.

\section{THREE-WAY VALVES}

Q6OIE, F, K, L

1. Set the lift adjustment $1 / 2$ division above the rated valve lift (Table IV).

2. With motor closed and valve at bottom of stroke, loosen locknut and turn adjustment screw down until top of washer is even with pointer (same as for twoway valve).

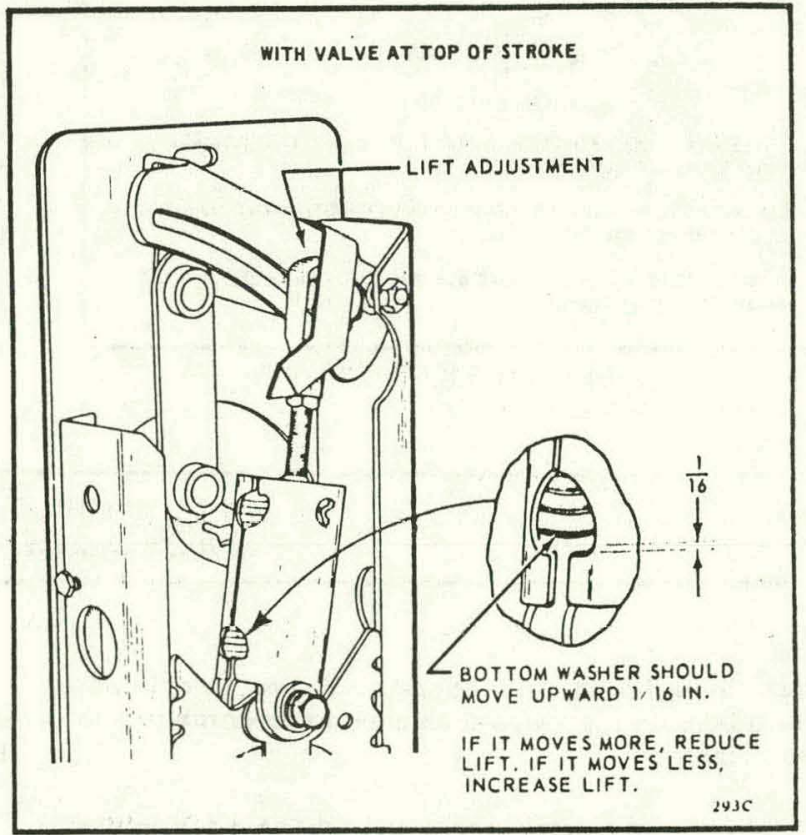

FIG. 5-THREE-WAY VALVE ADJUSTMENT. 
3. Run the motor all the way open. Washer at bottom of strain relief spring should move up $1 / 16$ inch-

- If it moves more, reduce lift adjustment.

-If it moves less, increase lift adjustment.

If lift adjustment is changed, reset close-off tension at bottom of stroke before going on.

\section{Q6015, $M$}

1. With motor closed and valve at bottom of stroke, loosen locknut and turn adjustment screw down until top of washer is even with pointer (same as for twoway valves).
2. Tun the motor all the way open. Washer at bottom of strain relief spring should move up approximately the same distance as top washer moved down.

If bottom washer moves more-turn adjusting screw up (counterclockwise $\bigcirc$ ).

If bottom washer moves less-turn adjusting screw down (clockwise $\bigcirc$ ).

Adjust screw until washer movement is equal. If tension is incorrectly adjusted, valve may not close off tightly.

\section{OPERATION}

The Q601E, F, K, L operate the valve in a 160 degree stroke. See Fig. 6. The Q601J, M heat-cool sequenced linkages operate the valve in a 100 degree stroke. Auxiliary switches operate in the remaining 60 degrees to sequence the cooling equipment. See Fig. 7.

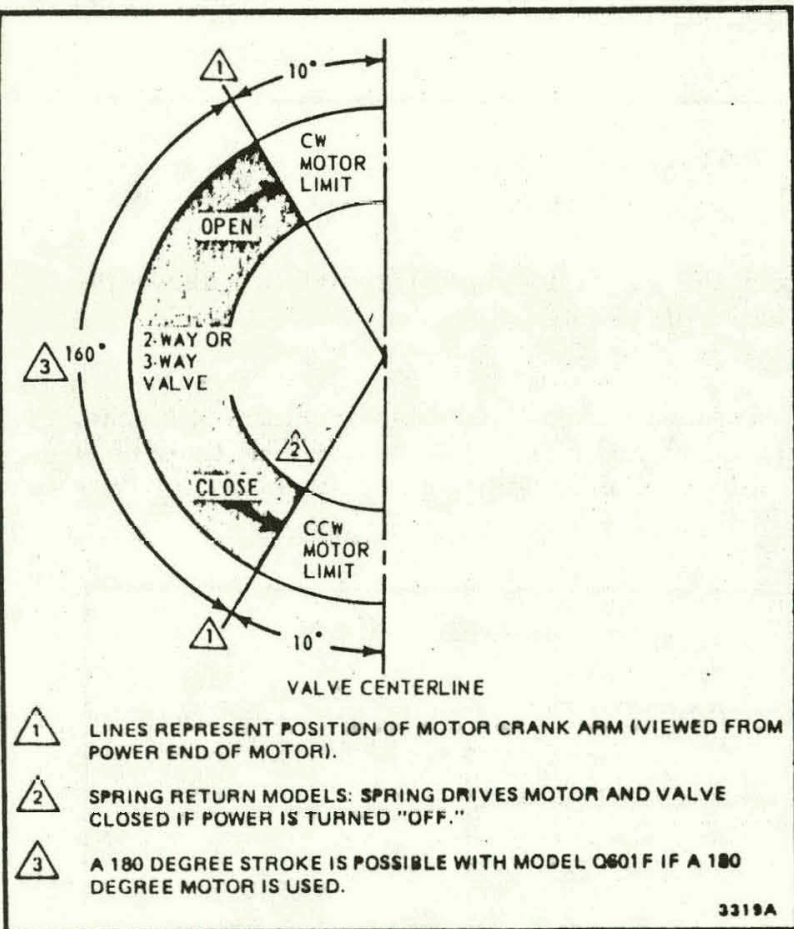

FIG. 6-OF Q601E,F,K,L OPERATION

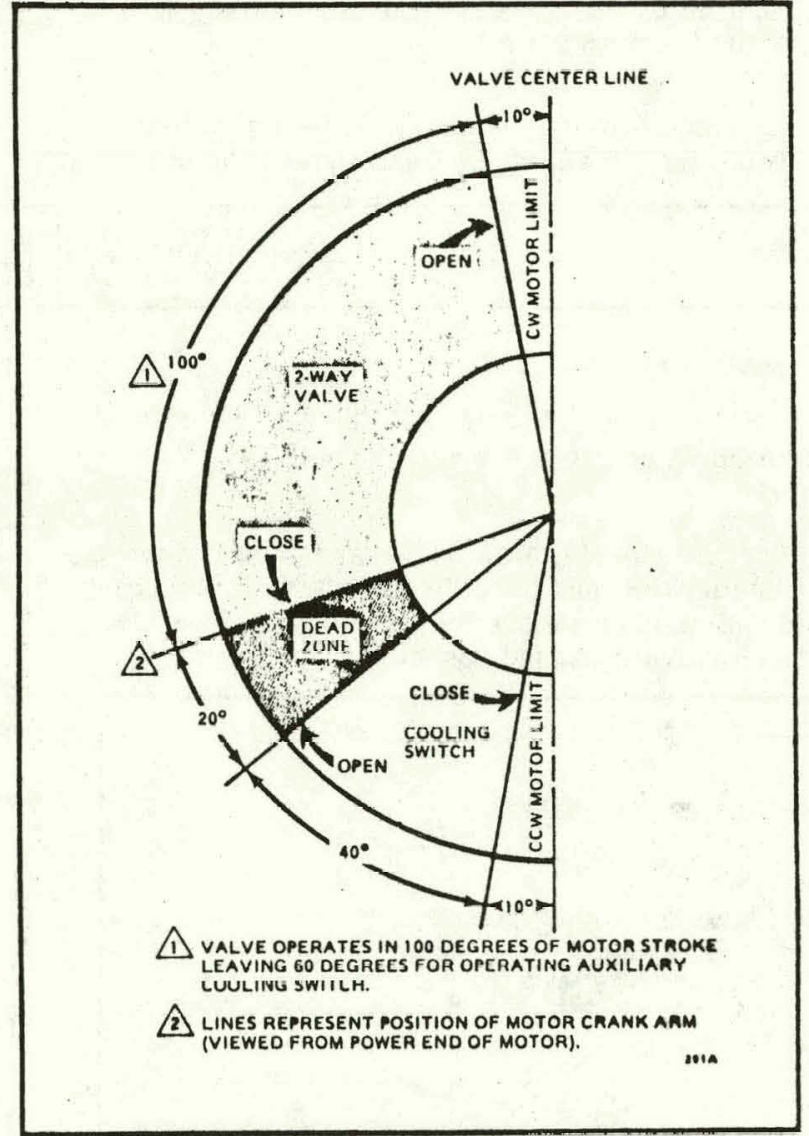

FIG. 7-OF Q601J,M OPERATION

\section{CMIECROUT}

After installation and adjustment are completed, check to be sure the valve-linkage-motor combination works properly.

Refer to the appropriate instruction sheet for information on running the motor during checkout.
A two-way valve should close off tightly (compressing spring 1/16 inch) and not bind at the open end of its stroke.

A three-way valve should close off tightly (compressing spring $1 / 16$ inch) at both ends of its stroke. 
THE 0618 VALVE LINKAGE CONNECTS A MODUTROL MOTOR TO A 2. OR 3-WAY VALVE. IT IS USED ON HONEYWELL STEAM AND WATER VALVES HAVING A 3/4 INCH [19 MM] STROKE AND A 1-3/8 INCH [35 MM] BONNET, SUCH AS THE V5011 OR V5013.

$\square$ Linkage requires no adjustment for use on either 2-or 3-way valves.

$\square$ Linkage mounts easily on Modutrol motors and valves.

$\square$ Requires no adjustment, either at installation or later.

口Small, lightweight unit requires little space on the installation.

$\square$ Available with either 80 or 160 pound sealoff force.

3.K.

REV. 8-75 (.012)
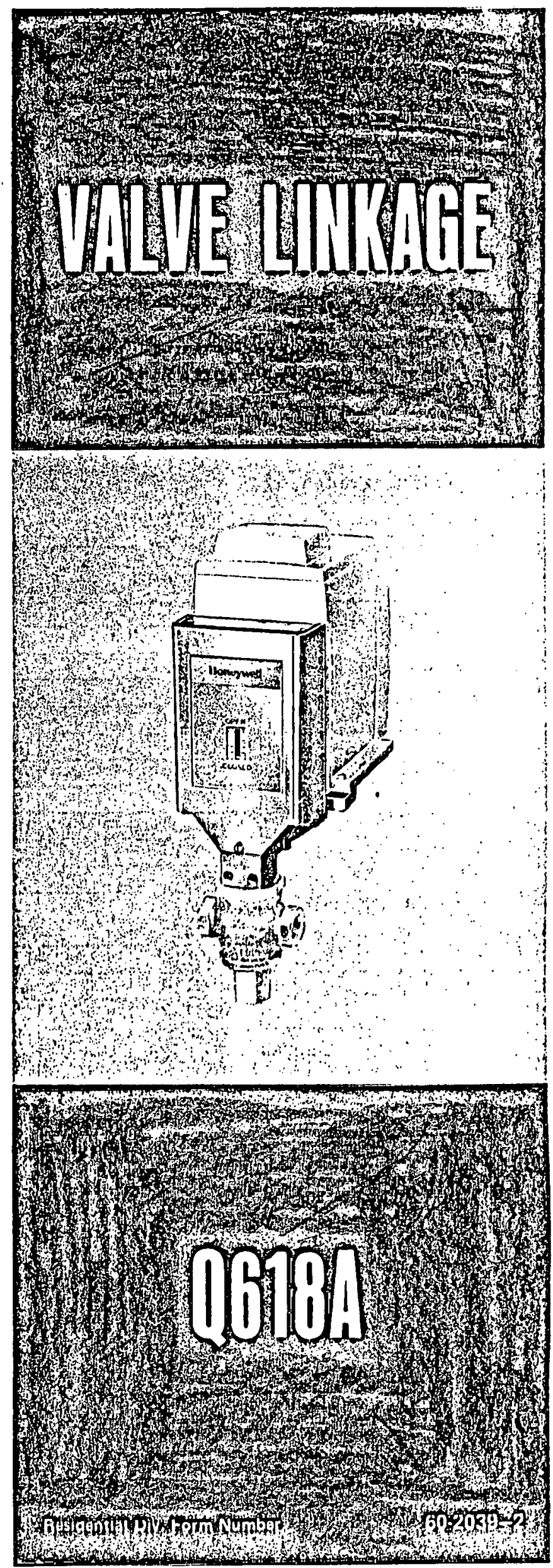
TRADELINE MODELS

Tradeline models are selected and packaged to provide ease of stocking, ease of handling, and maximum replacement value. Tradeline model specifications are the same as those of standard models except as noted below.

TRADELINE MODELS:

Q618A Valve Linkage with 80 or $160 \mathrm{lb}$. seal-off force on valve stem.
ADDITIONAL FEATURES: Tradeline pack with cross reference label and special instruction sheet.

\section{STANDARD MODELS}

MODEL: Q618A Valve Linkage.

STROKE: $3 / 4$ inch [ $19 \mathrm{~mm}$ ], fixed.

SEAL-OFF FORCE ON VALVE STEM: 80 or 160 pounds.

VALVE BONNET SIZE: $1 \cdot 3 / 8$ inches [ $35 \mathrm{~mm}$ ].

TEMPERATURE RATINGS: Limited only by temperature rating of valve and motor.
WEIGHT: $3-1 / 2$ pounds.

MOTOR REQUIRED:

160 pound-M944, M644, M941.

80 pound-M945, M445, M845, M934, M634.

MOTOR STROKE: 160 degrees-normally open or normally closed.

DIMENSIUNNS: See Fiy. 1.

LINKAGE REPLACEMENT INFORMATION:

\begin{tabular}{|c|c|c|c|c|}
\hline \multirow{2}{*}{ OLD LINKAGES } & \multicolumn{2}{|c|}{ TYPICALLY USED ON- } & \multicolumn{2}{|c|}{ REPLACEMENT LINKAGES } \\
\hline & VALVE & SIZE IN INCHES [MM] & STANDARD & TRADELINE \\
\hline \multirow{5}{*}{ Q455C and Q601D } & V.5n11 & $1 / 2-3[12.5-76]$ & Q618A1008 & 0618A1024 \\
\hline & V5013 & $1 / 2-3[12.5-76]$ & Q618A1008 & O618A1024 \\
\hline & $V 5047 a$ & $1-1.1 / 2[25.5-38]$ & $0601 K 1003$ & - \\
\hline & V5047 & $2[51]$ & Q618A1008 & Q618A1024 \\
\hline & V5051a & $2 \cdot 1 / 2-6[63.5-152.5]$ & $0601 K 1003$ & - \\
\hline \multirow{2}{*}{ Q455D } & V5011a & $4-6[101.5-152.5]$ & $0601 E 1000$ & - \\
\hline & V5013a & $4-6[101.5-152.5]$ & Q601E1000 & - \\
\hline \multirow{2}{*}{$\mathrm{Q} 455 \mathrm{E}$ and $\mathrm{Q} 601 \mathrm{H}$} & V5011a & $4-6[101.5-152.5]$ & Q601F 1009 & - \\
\hline & $V 5013^{a}$ & $4-6[101.5-152.5]$ & Q601F1009 & - \\
\hline \multirow{5}{*}{ Q445F and Q601G } & V5011 & $1 / 2-3[12.5-76]$ & Q618A1016 & Q618A1032 \\
\hline & V5013 & $1 / 2-3[12.5-76]$ & Q618A1016 & O618A1032 \\
\hline & V5047a & $1-1-1 / 2[25.5-38]$ & Q601L1002 & - \\
\hline & V5047 & $2[51]$ & O618A1016 & Q618A1032 \\
\hline & V5051a & $2 \cdot 1 / 2-6[63.5-152.5]$ & $0601 L 1002$ & - \\
\hline \multirow{2}{*}{ Q455G } & V5011a & $1 / 2-3[12.5 \cdot 76]$ & Q601M1001 & Q6ก1M1019 \\
\hline & V5013a & $1 / 2-3[12.5-76]$ & Q601M1001 & Q601M1019 \\
\hline
\end{tabular}

aSee Q601 Specification Sheet, 71-92136.

(continued on page 3)

\section{ORDERING INFORMATION}

WHEN ORDERING REFER TO THE TRADELINE CATALOG OR PRICE SHEETS FOR COMPLETE ORDERING SPECIFICATION NUMBER, OR

SPECIFY -

1. MODEL NUMBER, SPECIFY TRADELINE, IF DESIRED.

2. SEAL-OFF FORCE.
ORDER FROM-

1. YOUR USUAL SOURCE, OR

2. HONEYWELL

1885 DOUGLAS DRIVE NORTH

MINNEAPOLIS, MINNESOTA 55422

(IN CANADA-HONEYWELL CONTROLS LIMITED 740 ELLESMERE ROAD SCARBOROUGH, ONTARIO)

INTERNATIONAL SALES AND SERVICE OFFICES IN ALL PRINCIPAL CITIES OF THE WORLD. 

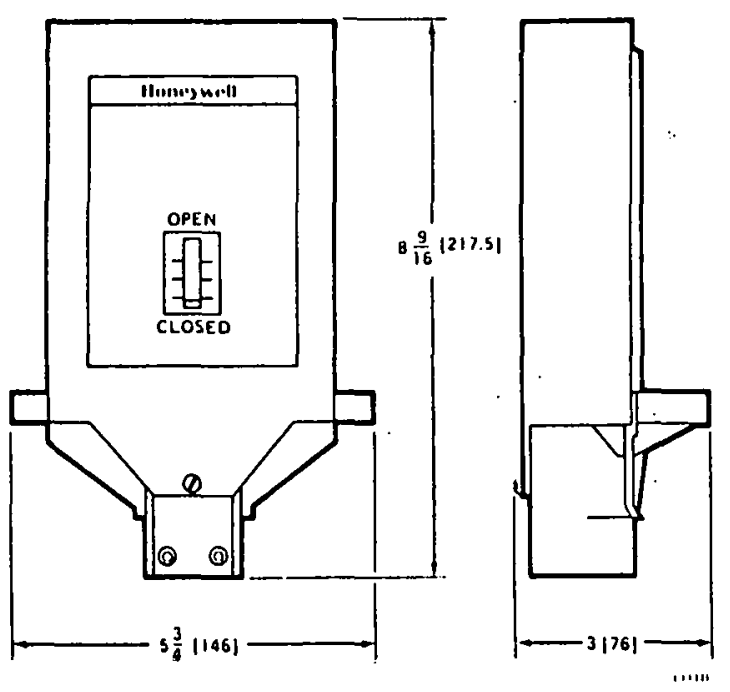

FIG. 1-0618 INSTALLATION DIMENSIONS, IN INCHES [MILLIMETERS SHOWN IN BRACKETS].

\section{$\because \cdots, \quad$ CAUTION \\ 1. Installer must be a trained, experiencẹd: serviceman. \\ 2. Disconnect power supply before beginning installation. \\ 3. Always conduct a thorough checkout when installation is complete.}

The Q618A mounts on the power end of a Modutrol motor. The linkage and motor can be rotated 360 degrees around the valve stem. The motor, however, must be installed with the shaft in a horizontal position.

Refer to the instructions packed with the valve for information on valve installation.

Wiring diagrams and other motor installation information are found in the appropriate motor instruction sheet.

\section{MOUNT LINKAGE ON MOTOR}

1. Remove the cover from the linkage.

2. Mount the cam on the shaft at the power end of the motor. Note that the key on the cam must fit into the keyway on the motor shaft.

3. Use the 2 bolts provided to fasten the linkage to the base of the motor. Note that the slide mechanism will have to be compressed slightly to fit over the cam. Put the nuts on these bolts, but leave them slightly loose (Figs. 2 and 3 ).

4. Fasten the linkage to the motor with the 2 captive self-tapping screws in the linkage.

5. Tighten the 2 machine bolts (step 3 above).

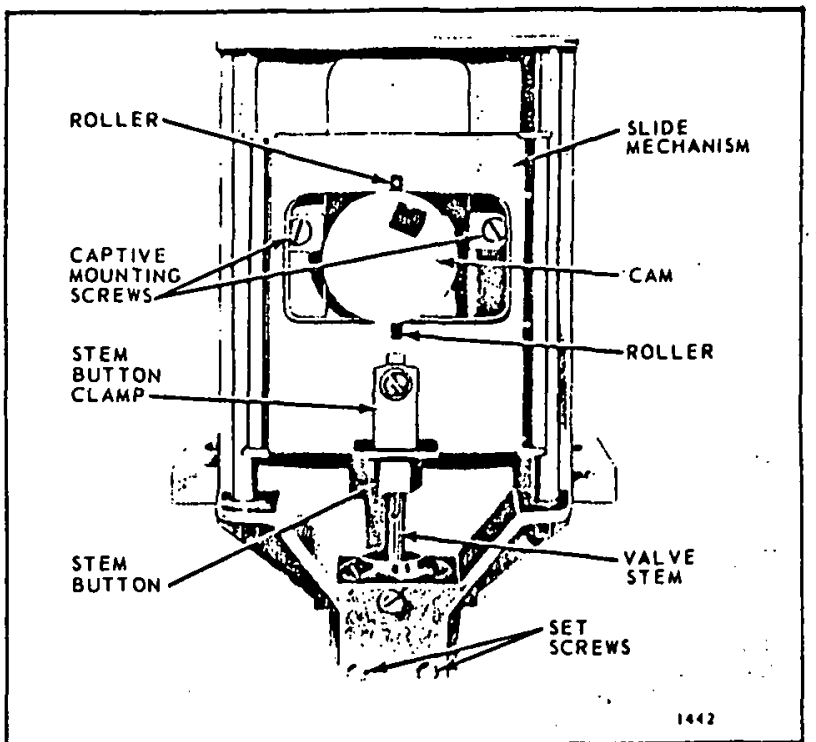

FIG. 2-INTERNAL PARTS OF THE 0618 VALVE LINKAGE.

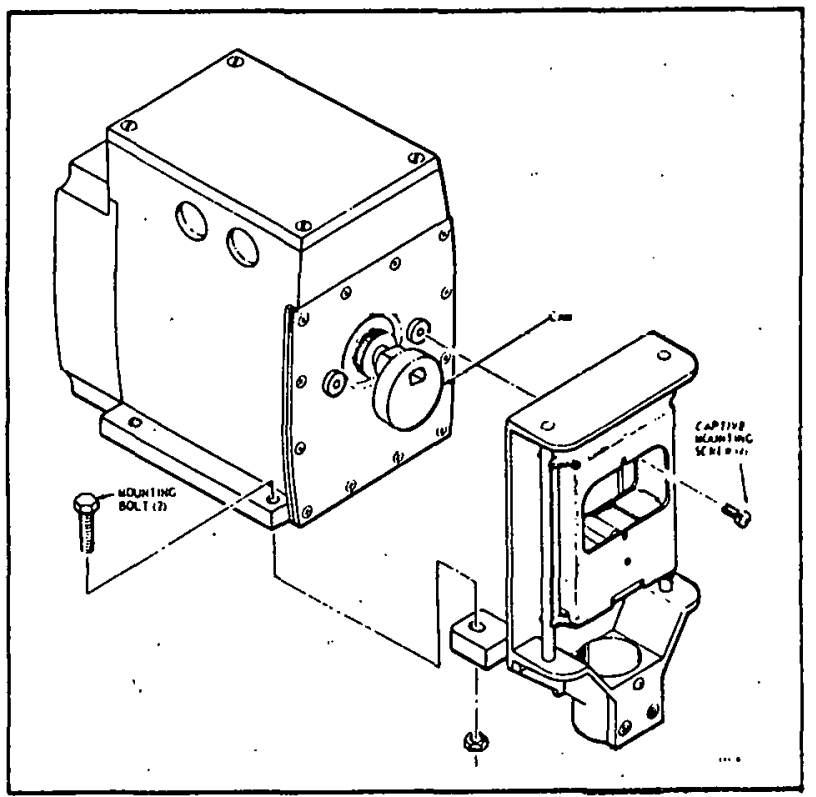

FIG. 3-ASSEMBLY OF THE 0618 VALVE LINKAGE TO A MODUTROL MOTOR.

\section{MOUNT LINKAGE AND MOTOR ON VALVE}

\section{CAUTION}

Make sure nut on valve stem is tight.

1. Remove the stem button clamp.

2. Loosen, if necessary, the 2 setscrews and slide the linkage over the valve bonnet (Fig. 4).

3. Tighten the 2 setscrews to secure the linkage and motor to the value. 


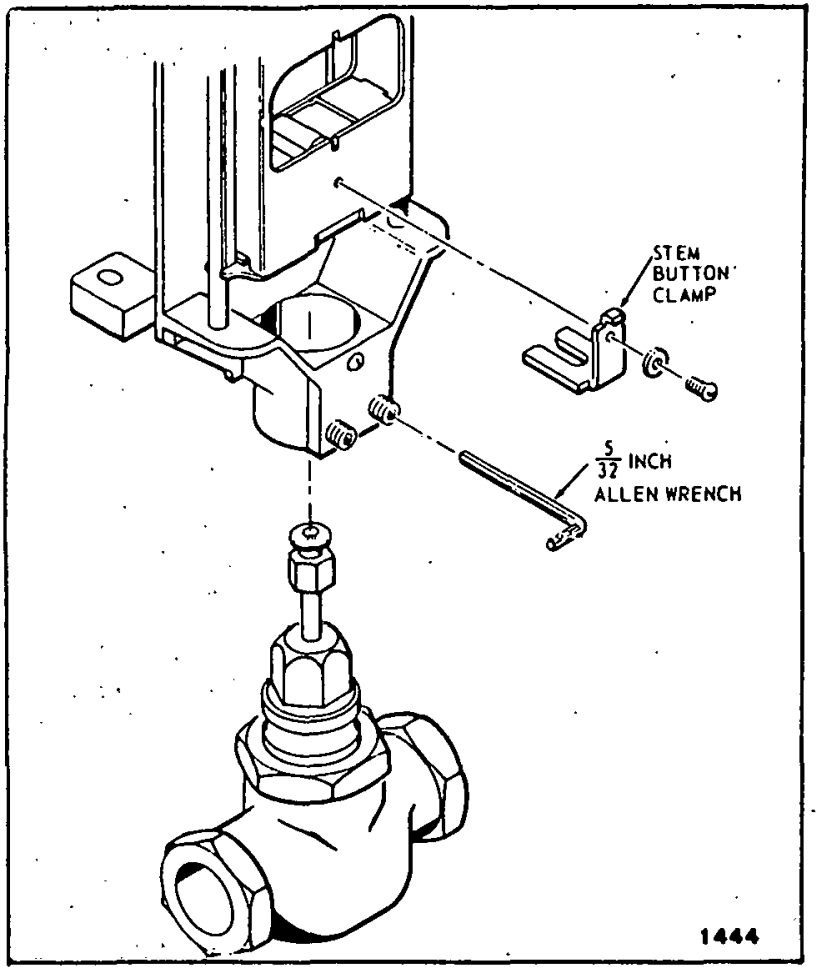

FIG. 4-ASSEMBLY OF THE LINKAGE TO THE VALVE.

\section{CONNECT VALVE STEM TO LINKAGE NORMALLY CLOSED MOTORS}

1. Place a heavy duty screwdriver under the linkage slide and into the slot in the back of the linkage (Fig. 5).

2. Use the screwdriver as a lever to force the slide mechanism up (compressing the tension relief spring) until the stem button clamp can be fully inserted into its slot.

3. Replace and tighten the stem button clamp screw.

4. Replace the cover on the valve linkage.

NORMALLY OPEN MOTORS

1. Place a heavy duty screwdriver between the slide mechanism and the top of the linkage frame.

2. Use the screwdriver as a lever to force the slide mechanism down until the stem button clamp can be fully inserted into its slot.

3. Replace and tighten the stem button clamp screw.

4. Replace the cover on the valve linkage.

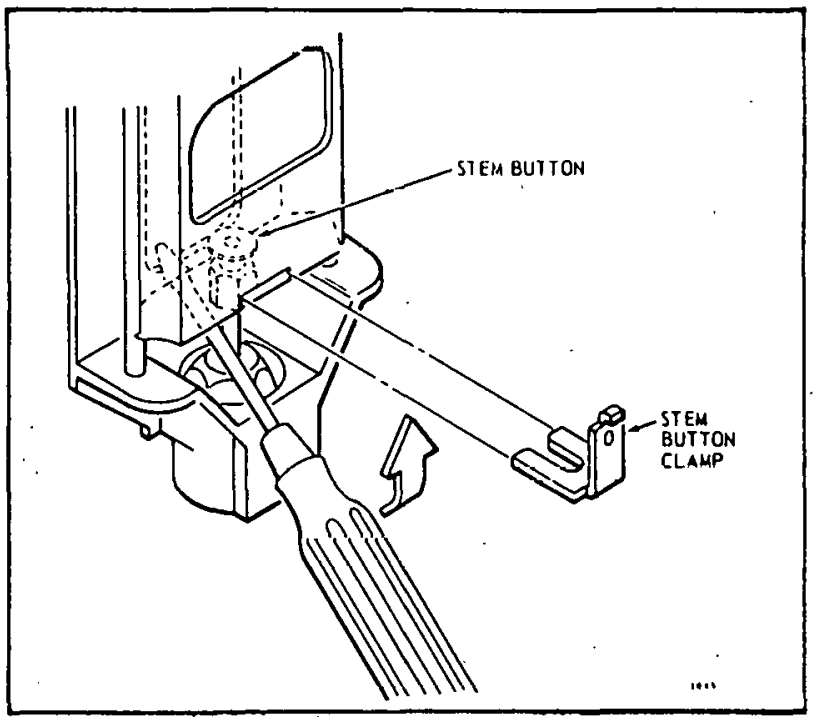

FIG. 5-THE STEM BUTTON CLAMP FASTENS THE VALVE STEM TO THE LINKAGE SLIDE MECHANISM.

\section{CHECKOUT}

After installation has been completed, the motor linkage, and valve should be checked for the following points of operation.

1. Motor should be free to run through its complete stroke.

2. The linkage should work freely without binding.

3. The valve must close off tightly at the bottom of its stroke (both ends of stroke for 3-way valve). Check for at least $1 / 32[.8 \mathrm{~mm}]$ deflection of the roller bracket in closed position (Fig. 6).

Refer to the motor instructions for motor checkout procedure.

\section{LUBRICATION}

The Q618 Valve Linkage was lubricated at the factory and should require no additional lubrication at the time of installation. For optimum performance, the slide mechanism rollers may be lubricated yearly with a good grade of cup grease.

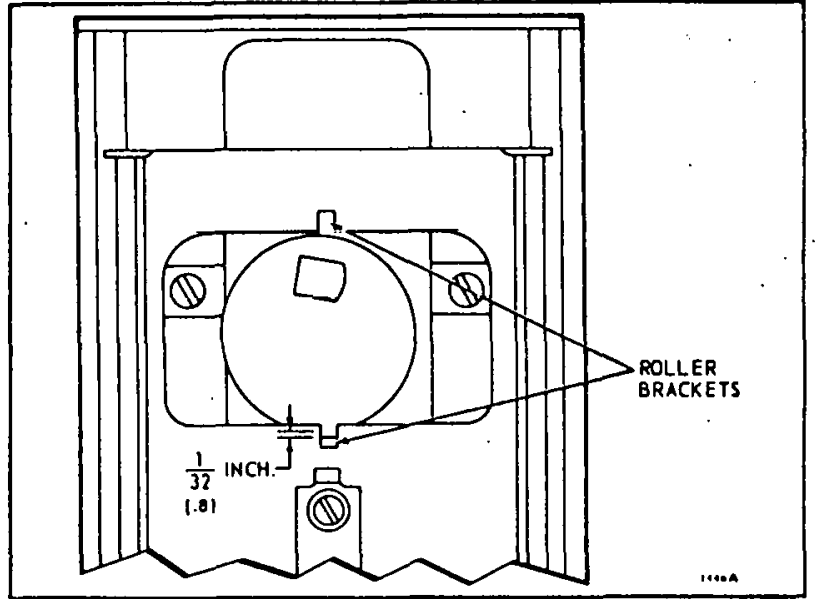

FIG. 6-FOR TIGHT CLOSE.OFF, THE ROLLER BRACKET ON THE LINKAGE MUST BE DEPRESSED AT LEAST $1 / 32$ INCH [.8 MM] AT THE END OF THE MOTOR'S STROKE. 
THE R7412 DIFFERENTIAL TEMPERATURE CONTROLLER PROVIDES AUTOMATIC CONTROL OF CIRCULATING PUMPS, VALVES, DAMPERS, MOTORS, AND OTHER ACCESSORIES USED IN SOLAR ENERGY SYSTEMS.

- All models contain a solid state differential temperature controller.

D R7412B,C include freeze protection.

- R7412D,E include overtemperature protection.

$\square$ R7412F includes freeze and overtemperature protection (field adjustable), and an auxilialy yelay driver.

- Plug-in resistors permit changing on and off temperature differential and adapt. ing R7412 for single function temperature control.

C R7412B-E overtemperature and freeze protection set points are selectable for factory setting, but are not fiold adjuctable.

$\square$ Uses one or two C773 Temperature Sensors.

$\square$ Separate sensors are not required for freeze and/or overtemperature protection.

R.L.

REV. $2-78(.09)$ 


\section{SPECIFICATIONS}

IMPORTANT

THE SPECIFICATIONS GIVEN IN THIS PUBLICATION DO NOT INCLUDE NORMAL MANUFACTUAING TOLERANCES. THEREFORE, THIS UNIT MAY NOT MATCH THE LISTED SPECIFICA TIONS EXACTLY. ALSO, THIS PRODUCT IS TESTED AND CALIBRATED UNDER CLOSELY CONTROLLED CONDITIONS, AND SOME MINOR DIFFERENCES IN PERFOR. MANCE CAN BE EXPECTED IF THOSE CONDITIONS ARE CHANGED.

\section{TRADELINE MODELS}

TRADELINE MODELS are selected and packaged for ease of stocking, ease of handling, and maximum replacement value. TRADELINE specifications are the same as those of standard models except as noted below.

TRADELINE MODEL AVAILABLE:

R7412F Differential Temperature Controller.
TRADELINE FEATURES:

- Includes freeze and overtemperature protection and an auxiliary relay driver.

- TRADELINE Pack with cross reference label.

\section{STANDARD MODELS}

\begin{tabular}{|c|c|c|c|c|}
\hline MÖDEEL & $\begin{array}{l}\text { DIFF. TFMP. } \\
\text { CONTROL }\end{array}$ & $\begin{array}{c}\text { FREEZE } \\
\text { PROTECTION }\end{array}$ & $\begin{array}{c}\text { OVERTTEMPERATURE } \\
\text { PROTECTION }\end{array}$ & $\begin{array}{l}\text { AUXILIARY RELAY } \\
\text { DRIVER }\end{array}$ \\
\hline R7412A & Yes $^{\mathrm{a}}$ & & & \\
\hline$R 7412 B$ & $Y_{e s}{ }^{a}$ & Yes ad & & \\
\hline R7412C & Yes a & Yescd & & Yesc \\
\hline$R 7412 D$ & $Y_{e s}{ }^{\text {d }}$ & & Yes bu & \\
\hline $\mathrm{R} 7412 \mathrm{E}$ & Yes a & & $Y_{e s}{ }^{c d}$ & Yes \\
\hline $\mathrm{R} 7412 \mathrm{~F}$ & $\mathrm{Yes}^{\mathrm{a}}$ & Yesacd & Yesbcd & Yesc \\
\hline
\end{tabular}

ánternal relay energizes. ${ }^{b}$ Internal relay de-energizes. ${ }^{C}$ Auxiliary relay energizes. dProtection setpoint is factory fixed.

\section{TEMPERATURE SETTING RANGES:}

Control Range- 0 to plus $210 \mathrm{~F}$ [minus 18 to plus $99 \mathrm{C}]$ as defined by temperature of low tempera. ture sensor.

Differential Temperature Controller-Adjustable ON and $\mathrm{OFF}$ differentials from minus 10 to plus $40 \mathrm{~F}$ [minus 5.6 to plus $22.2 \mathrm{C}$ ]. Factory-set at $18 \mathrm{~F}$ $[10 \mathrm{C}]$ temperature difference $\mathrm{ON}$ and $3 \mathrm{~F}$ [1.7 C] temperature difference OFF. Plug-in resistors vary settings (see Table 1, page 7).

Freeze Protection-

R7412B,C set point may be specified at 37,42 , or
$47 \mathrm{~F}[3,6$, or $8 \mathrm{C}]$, but it is factory fixed.

$\mathrm{R} 7412 \mathrm{~F}$ has field adjustable settings at 37,42 , or $47 \mathrm{~F}[3,6$, or $8 \mathrm{C}]$.

Freeze differential $-3 \mathrm{~F}$ [1.7 C].

Overtemperature Protection-

R7412D,E set point may be specified at $5 \mathrm{~F}$

[3.2 C] increments from 140 to $190 \mathrm{~F}$ [ 60 to $88 \mathrm{C}]$, but it is factory fixed.

R7412F has field adjustable settings in $5 \mathrm{~F}$ [3.2 C] increments from 140 to $190 \mathrm{~F}[60$ to $88 \mathrm{C}]$. Overtemperature differential . $10 \mathrm{~F}[5.5 \mathrm{C}]$.

(continued on page 3)

\section{ORDERING INFORMATION}

WHEN PURCHASING REPLACEMENT AND MODERNIZATION PRODUCTS FROM YOUR TRADELINE WHOLESALER OR YOUR DISTRIBUTOR, REFER TO THE TRADELINE CATALOG OR PRICE SHEETS FOR COMPLETE ORDERING NUMBER, OR SPECIFY-

1. Differential Temperature Controller order

3. Freeze protection $(R 7412 B, C)$ or overtemperature number. protection $(R 7412 D, E)$ set point desired.

2. Temperature Sensor order number (two

4. Immersion well order number. required).

5. Accessories, if desired.

6. Optional specifications, if desired.

IF YOU HAVE ADDITIONAL QUESTIONS, NEED FURTHER INFORMATION, OR WOULO LIKE TO COMMENT ON OUR PRODUCTS OR SERVICES, PLEASE WRITE OR PHONE:

1. YOUR LOCAL HONEYWELL RESIDENTIAL DIVISION SALES OFFICE (CHECK WHITE PAGES OF PHONE DIRECTORY).

2. RESIDENTIAL DIVISION CUSTOMER SERVICE HONE YWELL INC.. 1885 DOUGLAS DRIVE NORTH MINNEAPOLIS, MINNESOTA $55422 \quad(612) 542-7500$

(IN CANADA-HONEYWELL CONTROLS LIMITED, 740 ELLESMERE ROAD, SCARBOROUGH, ONTARIO MTP 2V9) INTERNATIONAL SALES AND SERVICE OFFICES IN ALL PRINCIPAL CITIES OF THE WORLD. 
ELECTRICAL RATINGS:

Input Voltage-120V ac, $60 \mathrm{~Hz}$.

Load Relay Contacts-

1 N.O. Pole-10 AFL/60 ALR at $120 \mathrm{~V}$ ac.

I N.C. Pole-125 VA at $120 \mathrm{~V}$ ac.

Auxiliary Relay Drive-5 VA maximum at $24 \mathrm{~V}$ ac, $60 \mathrm{~Hz}$.

Power Consumption -7 watts maximum.

\section{AMBIENT TEMPERATURE RANGE:}

Controller-plus 20 to $115 \mathrm{~F}$ [minus 7 to plus $46 \mathrm{C}$ ].

Temperature Sensor-Minus 50 to plus $450 \mathrm{~F}$ [minus 46 to plus $232 \mathrm{C}$ ].

MOUNTING:

Controller-two screw holes in opposite corners of case. Mounting screws not included.

Electronic Temperature Sensor-Sensor is available for mounting with clip or has a flattened end with a mounting hole. Tank sensor mounts in an immersion well. See ACCESSORIES.

WIRING CONNECTIONS: 9 screw terminals. Also, 2 leadwires on R7412C,E,F,

DIMENSIONS: See Fig. 2.

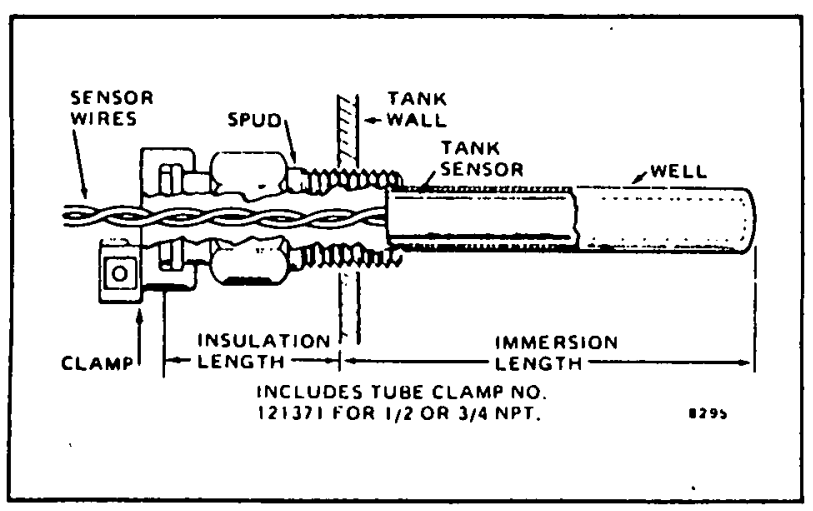

FIG. 1-TANK SENSOR INSERTED IN IMMERSION WELL.

\section{AUXILIARY RELAYS:}

R856A Fan Centers-

Line voltage spst and spdt switching.

Low voltage terminal strip for wiring thermostat and high side panel.

R8225A Fan Relay-spdt switching, one double throw contact.

R8225B Fan Relay-spst switching; normally open contacts.

R8225C Fan Relay--dpst switching; one normally open and one normally closed contact.

R8225D Fan Relay-dpst switching; one normally open main and one normally open auxiliary pole.

\section{OPTIONAL SPECIFICATIONS:}

Indicator Light-indicates when pump or fan are operating.

Auto-Off-On Switch-manual override switch which permits automatic operation of the controller or allows the controller to be switched directly ON and OFF. Switch does not affect the operation of the auxiliary relay in R7412C,E, and F.
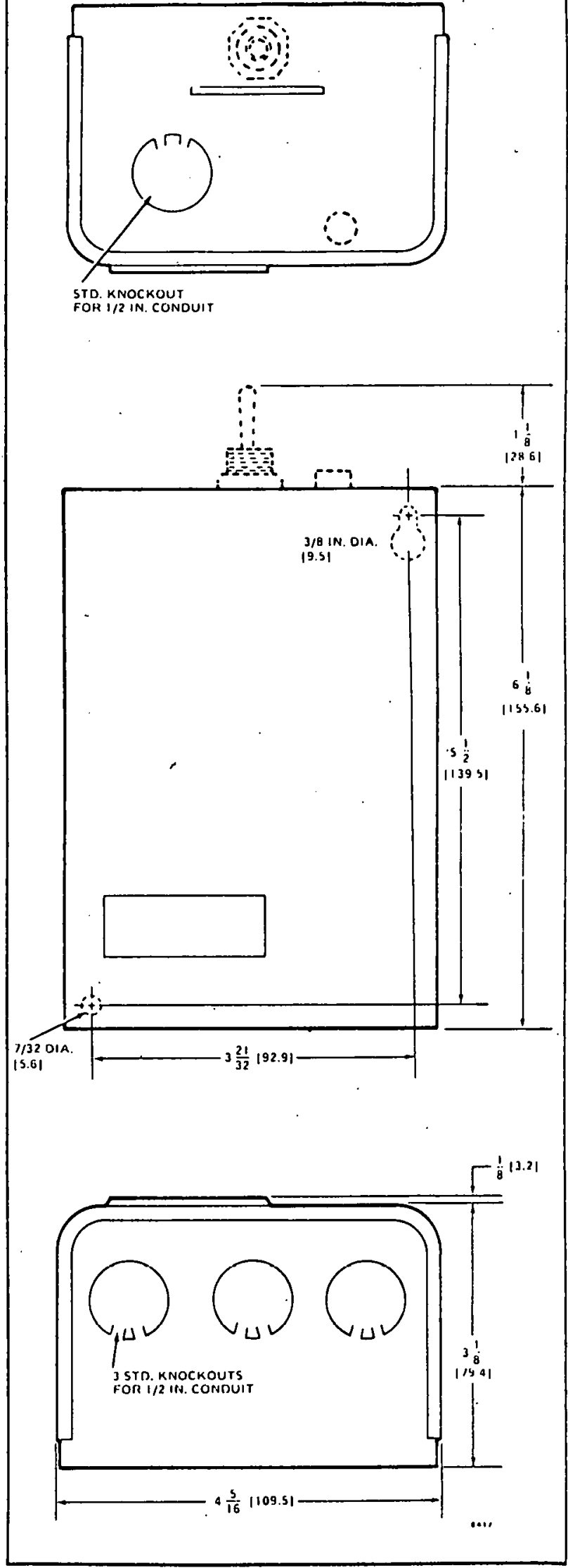

FIG. 2-R7412 MOUNTING DIMENSIONS IN INCHES [MILLIMETRES IN BRACKETS]. 
ACCESSORIES:

C773A Temperature Sensor. Single sensor mounts in storage tank with immersion well or on collector with mounting clip.

C773B Temperature Sensor. Double sensor mounts in storage tank with immersion well or on collector with mounting clip.

C773C Temperature Sensor. Single sensor has flattened end with mounting hole for collector in. stallation.
C773D Temperature Sensor. Double sensur has flat. tened end with mounting hole for collector in. stallation.

Immersion Well-for mounting sensor in storage tank. See immersion well table and Fig. 1.

Remote Sensor Wiring Compartment-mounts to im. mersion well. Part No. 111892 F.

\begin{tabular}{c|c|c|c||c|c|c|c}
\hline \multicolumn{3}{c||}{ WELL DIMENSIONS } & \multicolumn{3}{c}{$\begin{array}{c}\text { SELECT WELL MATERIAL AND } \\
\text { ORDER NUMBER BELOW }\end{array}$} \\
\hline $\begin{array}{c}\text { INSERTION } \\
\text { LENGTH }\end{array}$ & $\begin{array}{c}\text { INSULATION } \\
\text { LENGTH }\end{array}$ & \multicolumn{2}{c|}{ COPPER } & \multicolumn{2}{c}{ STAINLESS STEEL } \\
\hline in & $\mathrm{mm}$ & in & $\mathrm{mm}$ & $1 / 2 \mathrm{NPT}$ & $3 / 4 \mathrm{NPT}$ & $1 / 2 \mathrm{NPT}$ & $3 / 4 \mathrm{NPT}$ \\
\hline $3-3 / 8$ & 85.7 & $1.1 / 2$ & & $121371 \mathrm{~A}$ & $121371 \mathrm{~B}$ & $121371 \mathrm{E}$ & $121371 \mathrm{~F}$ \\
\hline $3 \cdot 3 / 8$ & 85.7 & $1.1 / 2$ & & - & $121371 \mathrm{Ka}$ & - & - \\
\hline $3 \cdot 3 / 8$ & 85.7 & 3 & & $121371 \mathrm{~L}$ & $121371 \mathrm{M}$ & - & - \\
\hline $5.3 / 8$ & 85.7 & 4 & & $122554 \mathrm{Ba}$ & $122555 \mathrm{Ba}$ & - & - \\
\hline $3.3 / 8$ & 136.5 & 4 & & $122554 \mathrm{Aa}$ & $122555 \mathrm{Aa}$ & - & - \\
\hline 6 & 152.4 & $1.1 / 4$ & 31.8 & $112620 \mathrm{BB}$ & - & - & - \\
\hline
\end{tabular}

aHas plastic sleeve on insertion well.

\section{INSTALLATION}

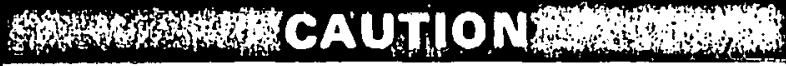

1. Installer must be a trained, experienced service technician.

2. Disconnect power supply before connecting wiring.

3. Conduct thorough checkout when installation is complete.

IMPOHTANI

Do NOT mount collector sensor to collector fluid channels. Protect sensor from extreme temperature conditions which may be encountered when the fluid channels are drained.

\section{MOUNTING CONTROLLER}

Loosen the cover screw and remove the cover. Locate the controller case on any convenient flat surface near the circulator or storage tank. Ambient temperature at location should not exceed $115 \mathrm{~F}$ [46 C]. Secure the controller using the 2 mounting holes located in opposite corners of the case and 2 mounting screws (not included).

\section{MOUNTING TEMPERATURE SENSORS}

Mount tank sensor and immersion well as follows:

1. Drain system fluid to a point below the sensor fitting. (Refer to Fig. 1.)

2. Screw the well into the threaded fitting. Use an approved pipe dope or Teflon tape to seal the threads.

3. Refill system and check for leaks.

4. Insert the sensor probe into the immersion well until it bottoms.

5. Attach retainer clamp over groove on well spud. Fit wires in clamp groove and lightly tighten screw. Do not over tighten.

Mount collector sensor according to the collector manufacturers recommendations. Fasten the sensor to the panel with a No. 8 or 10 screw (Fig. 3). Do NOT mount collector sensor to collector fluid channels. Do not exceed ambient temperature ratings.

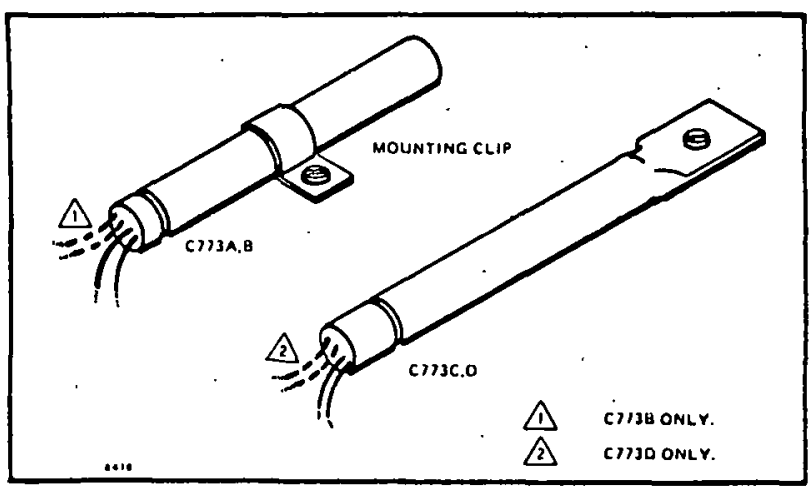

FIG. 3-MOUNTING THE 6773 TEMPERATURE SENSOR. 


\section{WIRING}

All wiring must comply with applicable codes and ordinances. The R7412 can be used for numerous applications in solar energy systems. Refer to Figs. 4 through 7 for typical examples of R7412 hookups. Also, the OPTIONAL APPLICATIONS section depicts the R74l 2 using only one temperature sensor.

The temperature sensors are wired to the controller through the $1 / 2$ inch knockout for conduit in the top of the controller case. Wire the power supply, relay contacts, and auxiliary relay driver using the three knockouts for
$1 / 2$ inch conduit in the bottom of the controller wase (Fig. 1).

If the amount of sensor cable used exceeds 100 feet [30.5 m], use No. 14 wire and grounded metallic conduit or two conductor shielded cable. Connect the shield to ground at the controller. Grounded metallic conduit and shielded cable (such as Belden 8762 or equivalent) minimizes possible radio frequency signal interference.

$111892 \mathrm{~F}$ Remote Sensor Wiring Compartment is available for tank sensor wiring (see ACCESSORIES).

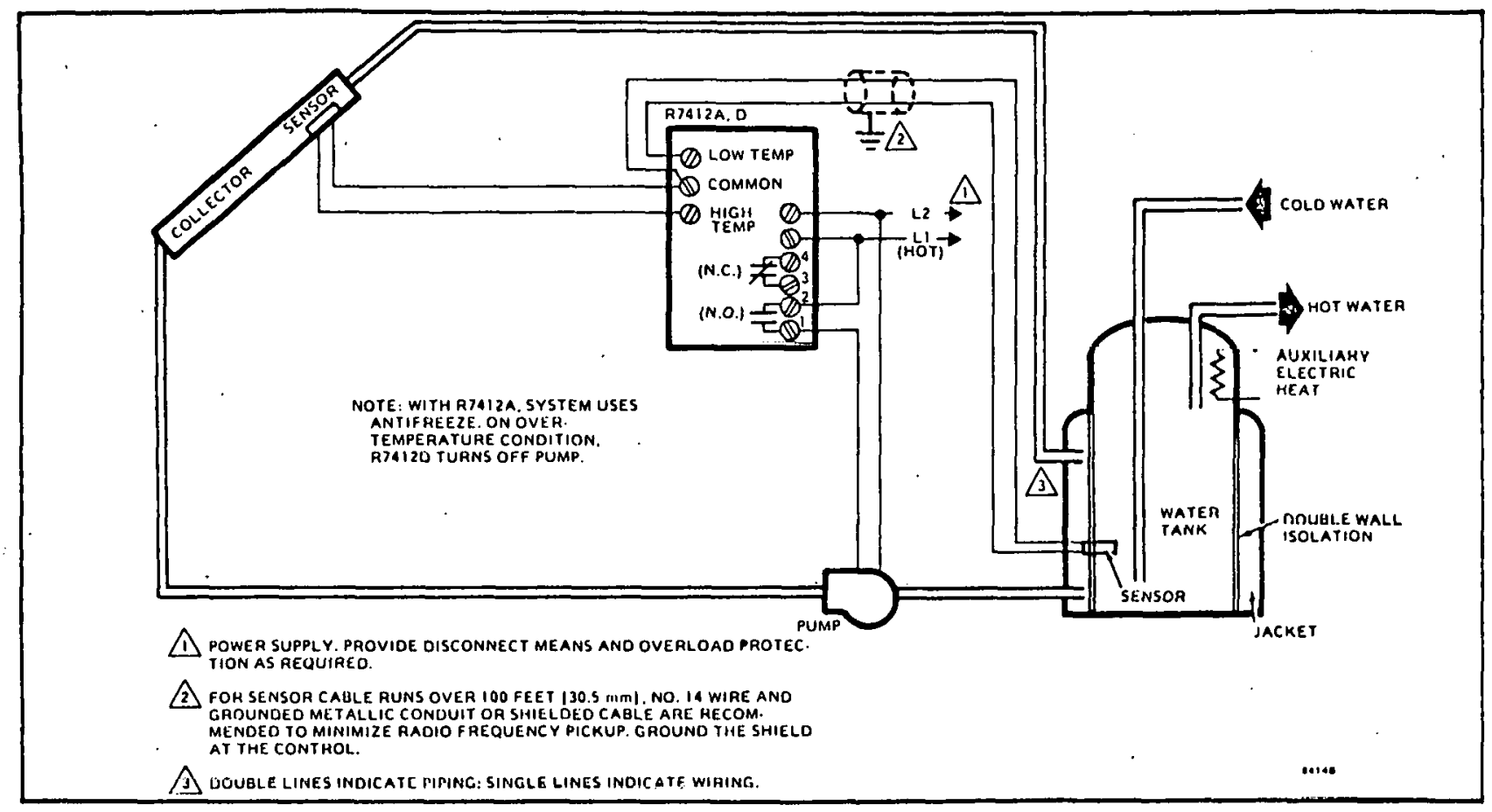

FIG. 4-USING THE R7412A,D WITH A SOLAR WATER HEATER.

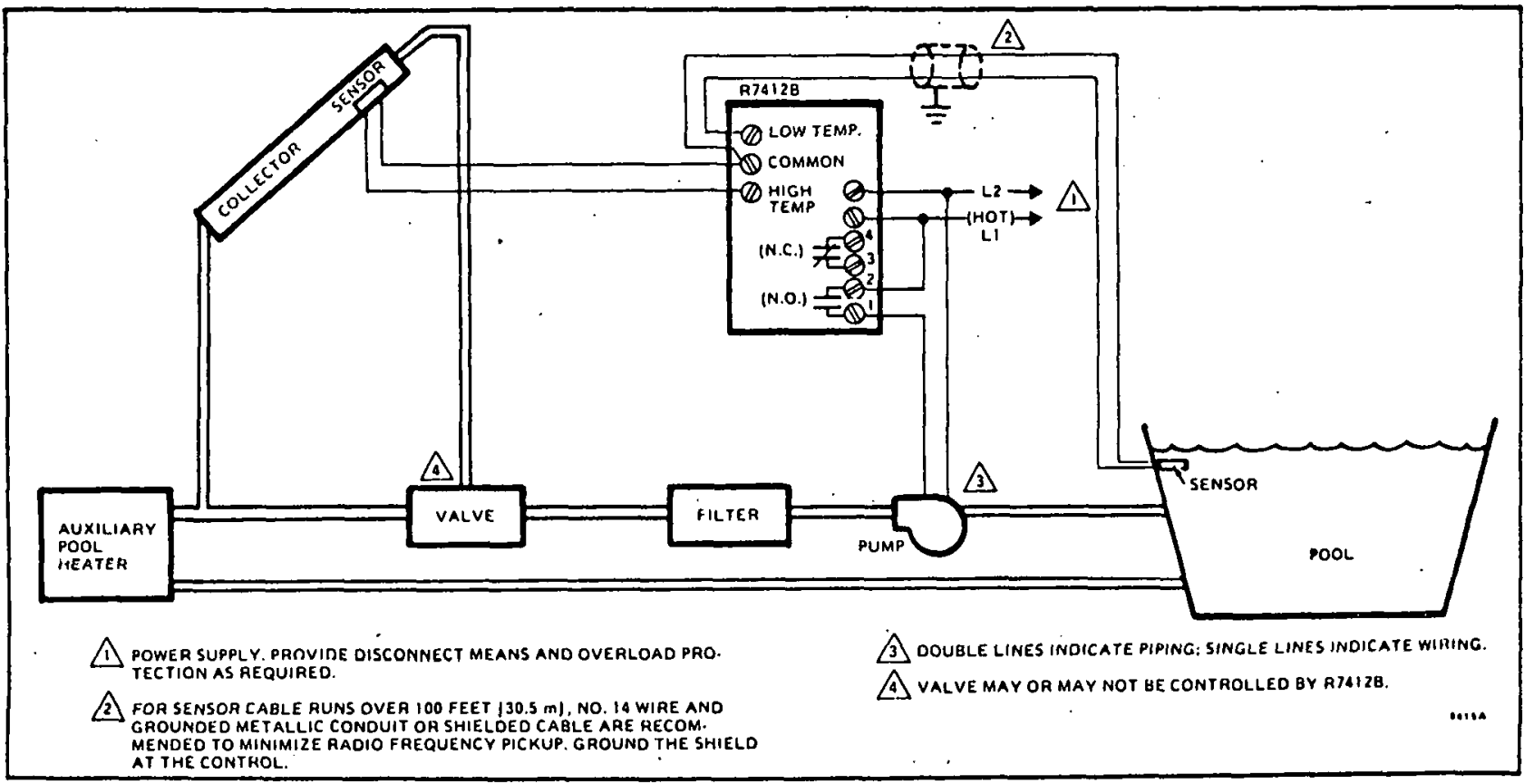

FIG. 5-USING THE R7412B WITH A SOLAR POOL HEATER. CONTROLLER ENERGIZES PUMP DURING FREEZE CONDITION. 


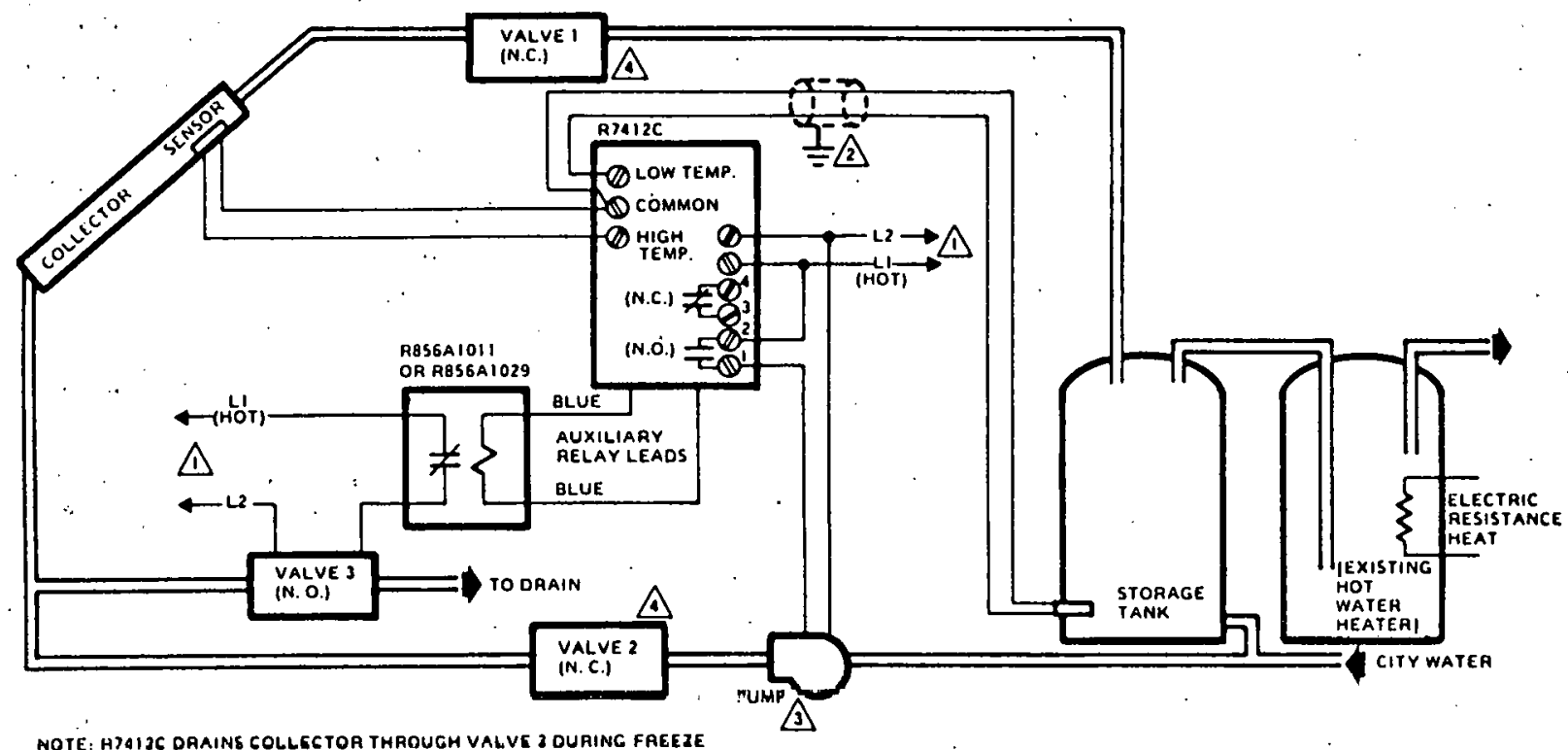
CONDITION.

(1) POWER SUPPLY. PHOVIOE DISCONNECT MEANS AND OVERLOAD PRO TECTION AS REOUIRED. 2. FOR SENSOR CABLE RUNS OVER 100 FEET 130.5 mI. NO. I WIRE AND
GROUNDED METALLIC CONOUIT OR SHIELOEO CABLE ARE AECOM. MENOCD TO MINIMILE RADIO FREQUENCY PICKUP. GROUND THE SHIELO AT THE CONTROL.

今 DOUDLC LINCS INOICATC FIPING: SINGLE LINES INDICATE WIRINO 4. WIRE VALVES I ANU 2 IN PAHALLEL WITH PUMP.

FIG. 6-INSTALLING THE R7412C IN A SOLAR HOT WATER HEATING SYSTEM.

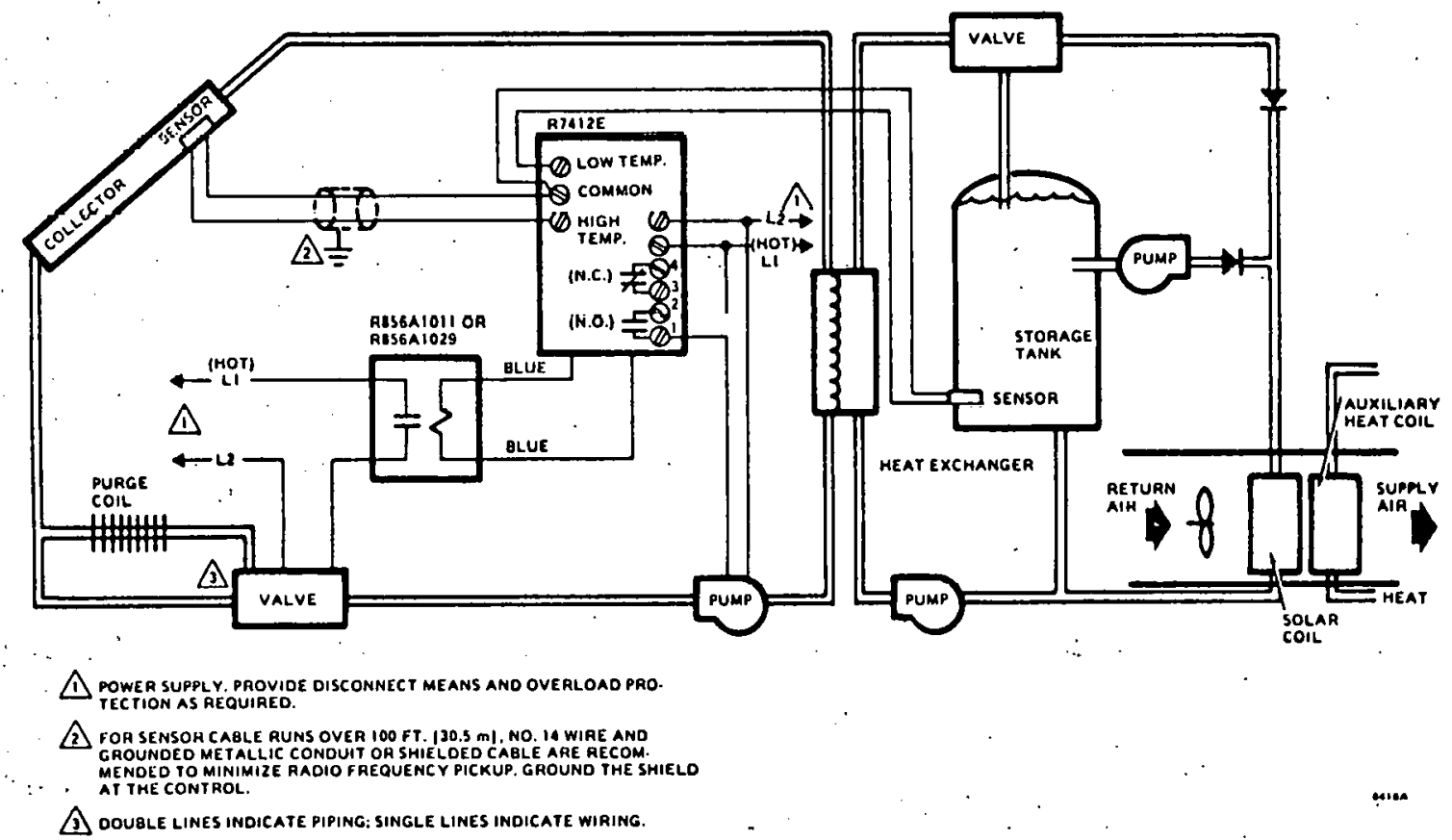

FIG. 7-TYPICAL INSTALLATION OF THE R7412E IN A SOLAR HOT WATER TO WARM AIR HEATING SYSTEM. 


\section{ADJUSTMENTS AND CHECKOUT}

\section{DIFFERENTIAL TEMPERATURE SELECTION}

The control settings may be adjusted by changing the ON and OFF plug-in resistors (see Fig. 8). The R741 2 is factory-set for pull-in at $18 \mathrm{~F}[10 \mathrm{C}]$ temperature difference with a $4750 \mathrm{ohm}$ ON resistor. Dropout is set for $3 \mathrm{~F}[1.7 \mathrm{C}]$ temperature difference with a $9760 \mathrm{ohm}$ OFF resistor.

To change either setting, refer to Table $I$ to select the resistor(s) needed. See Fig. 9 to prepare resistor for installation. Remove the old resistor and plug in the replacement. Be sure the correct resistor is inserted in the proper position. Use $1 / 8$ watt, 1 percent resistors, available locally.

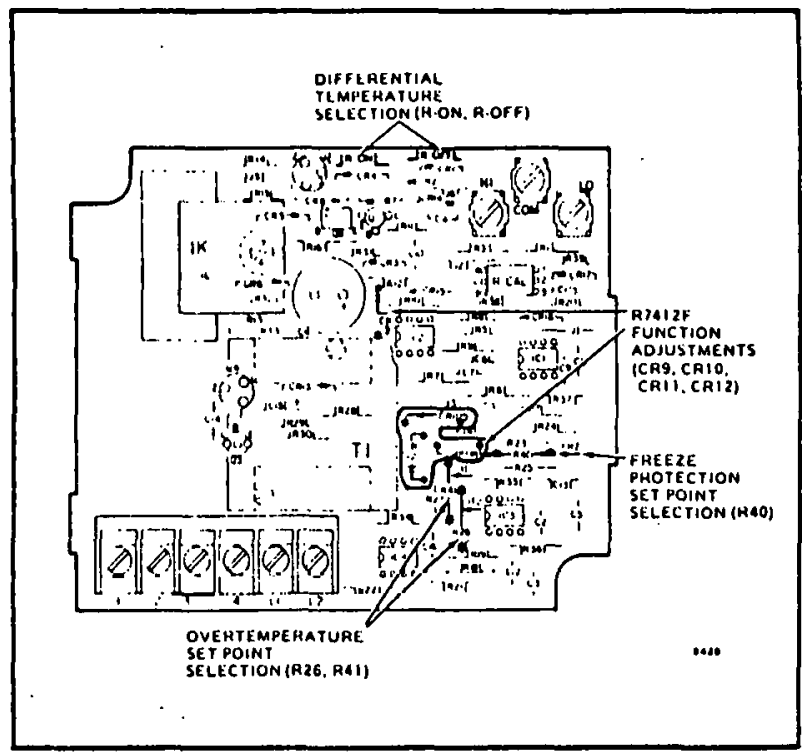

FIG. 8-ADJUSTMENT COMPONENTS OF THE R7412.

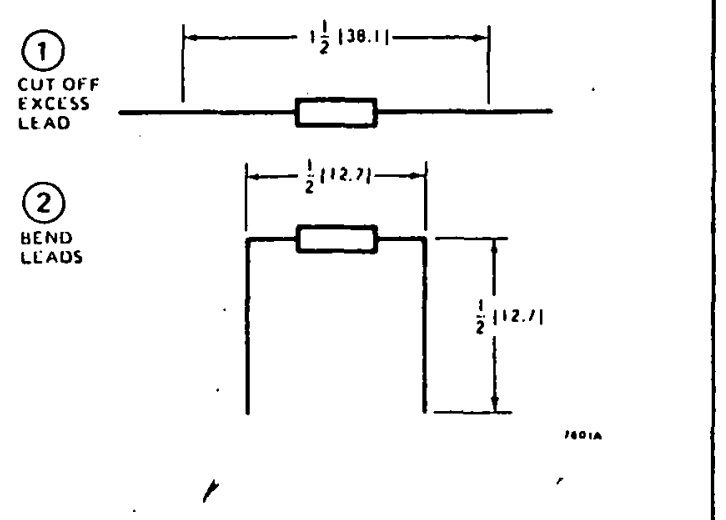

FIG. 9-PLUG.IN RESISTOR PREPARATION. DIMENSIONS IN INCHES [MILLIMETRES IN BRACKETS].

TABLE 1-ON, OFF DIFFERENTIAL TEMPERATURE CONTROL

FOR

TEMPERATURE

DIFFERENCE

OF:

\begin{tabular}{|c|c|c|}
\hline \multicolumn{2}{|c|}{ OF: } & \multirow{2}{*}{$\begin{array}{l}\text { RESISTORS } \\
\text { (IN OHMS) }\end{array}$} \\
\hline$F$ & C & \\
\hline-10 & -6.0 & 27500 \\
\hline .5 & -3.0 & 15400 \\
\hline 0 & 0 & 11500 \\
\hline 1 & 0.6 & 11000 \\
\hline 2 & 1.0 & 10500 \\
\hline 3 & 1.7 & 9760 \\
\hline 4 & 2.2 & 9310 \\
\hline 5 & 3.0 & 8870 \\
\hline 6 & 3.3 & 8250 \\
\hline 7 & 4.0 & 7870 \\
\hline 8 & 4.4 & 7500 \\
\hline 9 & 5.0 & 7150 \\
\hline 10 & 6.0 & 6810 \\
\hline 12 & 7.0 & 6340 \\
\hline 14 & 8.0 & 5620 \\
\hline 16 & 9.0 & 5230 \\
\hline 18 & 10.0 & 4750 \\
\hline $20^{a}$ & $11.0^{a}$ & $4220^{a}$ \\
\hline 25 & 14.0 & 3320 \\
\hline 30 & 17.0 & 2430 \\
\hline 35 & 19.0 & 1750 \\
\hline 40 & 22.0 & 1210 \\
\hline
\end{tabular}

a Maximum OFF setting must not exceed $20 \mathrm{~F}[11 \mathrm{C}]$; resistor value must be greater than 4220 ohms.

\section{R7412F FREEZE PROTECTION} TEMPERATURE SELECTION

Freeze protection setting is adjusted by changing the freeze protection plug-in resistor, R40 (see Fig. 8). The R741 2 freeze protection is factory-set at $37 \mathrm{~F} \mathrm{[} 3 \mathrm{C}$ ].

To change the setting to $37 \mathrm{~F}[3 \mathrm{C}]$, simply remove the freeze protection resistor and leave it open circuited. For a setting of $42 \mathrm{~F}[6 \mathrm{C}]$, install a 110 kilohm resistor using the resistor preparation indicated in Fig. 9. Use a 48.7 kilohm resistor to change the freeze protection setting to $47 \mathrm{~F}[8 \mathrm{C}]$.

\section{R7412F OVERTEMPERATURE SETTING SELECTION}

Overtemperature protection setting may be adjusted by changing the overtemperature protection resistors, OT1 (R41) and OT2 (R26) (see Fig. 8). The R741 2 overtemperature limit is factory-set at $140 \mathrm{~F}[66 \mathrm{C}]$.

To change the setting, refer to Table 2 to select the resistors needed. See Fig. 9 to prepare resistor for in. stallation. Remove the old overtemperature resistors and insert the correct resistor in the proper position. Use $1 / 8$ watt, 1 percent resistors, available locally. 
TABLE 2-OVERTEMPERATURE CONTROL

\begin{tabular}{|c|c|c|c|}
\hline \multicolumn{2}{|c|}{$\begin{array}{l}\text { FOR } \\
\text { OVER- } \\
\text { TEMPERA. } \\
\text { TURE } \\
\text { LIMIT OF: }\end{array}$} & \multirow[t]{2}{*}{$\begin{array}{c}\text { CHANGE } \\
\text { RESISTOR } \\
\text { OT1 (R41) } \\
\text { TO: } \\
\text { (OHMS) }\end{array}$} & \multirow[t]{2}{*}{$\begin{array}{c}\text { CHANGE } \\
\text { RESISTOR } \\
\text { OT2 (R26) } \\
\text { TO: } \\
\text { (OHMS) }\end{array}$} \\
\hline $\mathbf{F}$ & $\mathrm{C}$ & & \\
\hline 140 & 60 & 11,800 & 174,000 \\
\hline 145 & 63 & 16,900 & 113,000 \\
\hline 150 & 66 & 19,100 & 61,900 \\
\hline 155 & 68 & 22,100 & 44,200 \\
\hline 160 & 71 & 25,500 & 33,200 \\
\hline 165 & 74 & 30,900 & 27,400 \\
\hline 170 & 77 & 38,300 & 23,200 \\
\hline 175 & 79 & 52,300 & 20,000 \\
\hline 180 & 82 & 78,700 & 17,800 \\
\hline 185 & 85 & 154,000 & 15,800 \\
\hline 190 & 88 & Open & 14,300 \\
\hline
\end{tabular}

\section{ADJUSTING FUNCTIONS OF THE R7412F}

Refer to Fig. 8 for the location of the components which can be removed to change the function of the R7412F.

The R7412F can be modified to provide freeze protection through the internal relay, the auxiliary relay, both the internal and the auxiliary relay, or neither. Diodes CR9 and CRII control these types of freeze protection. If both CR9 and CRII remain in the controller, the internal relay will be energized as well as the auxiliary relay. Removing CR9 disables the internal relay; clipping out CRII disables the auxiliary relay. When both CR 9 and $C R I I$ are taken out, the freeze protection feature of the $R 7412 \mathrm{~F}$ is completely disabled.
Usually, CR9 or CRII is removed to provide freeze protection which is operated by either the internal relay or the auxiliary relay, but not both.

Also, the R7412F may be adjusted to give over. temperature protection through the internal relay, the auxiliary relay, both the internal and the auxiliary relay, or neither. Diodes CR10 and CRI 2 control these types of overtemperature protection. If both CRIO and CRI2 remain in the controller, the internal relay will be de. energized and the auxiliary relay will be energized. Removing CR10 prevents the internal relay from locking out the pump during overtemperature; clipping out CRI2 disables the auxiliary relay. If both CRIO and CRI2 are clipped out, the overtemperature protection capabilities of the $R 7412 \mathrm{~F}$ are completely disabled.

Normally, CRIO or CRI2 is clipped out to give overtemperature protection through the internal relay or auxiliary relay, but not through both.

In most cases the auxiliary relay is used for fresze protection or overtemperature protection, but not both. Therefore, CRII or CRI2 is usually removed when matifying the R7412F.

To convert the R7412F to models R7412A, B, C, D, or $\mathrm{E}$ use Table 3.

TABLE 3-R7412F ADJUSTMENTS

\begin{tabular}{c|l|l}
\hline $\begin{array}{c}\text { TO CONVERT } \\
\text { R7412F TO: }\end{array}$ & $\begin{array}{c}\text { CLIP } \\
\text { OUT: }\end{array}$ & \multicolumn{1}{|c}{$\begin{array}{c}\text { LEAVE } \\
\text { IN: }\end{array}$} \\
\hline R7412A & $\begin{array}{l}\text { CR9, CR10, } \\
\text { CR11, CR12 }\end{array}$ & \\
\hline R7412B & $\begin{array}{l}\text { CR10, CR11, } \\
\text { CR12 }\end{array}$ & CR9 \\
\hline R7412C & $\begin{array}{l}\text { CR9, CR10, } \\
\text { CR12 }\end{array}$ & CR11 \\
\hline R7412D & $\begin{array}{l}\text { CR9, CR11, } \\
\text { CR12 }\end{array}$ & CR10 \\
\hline R7412E & $\begin{array}{l}\text { CR9, CR10, } \\
\text { CR11 }\end{array}$ & CR12 \\
\hline
\end{tabular}

\section{OPERATION AND CHECKOUT}

\section{OPERATION}

The controller relay contacts make when the differential temperature is greater than the $O N$ setting and breaks when the temperature difference is less than the OFF setting.

\section{CHECKOUT}

Check control for proper operation as follows:

1. Disconnect low temperature terminal, jumper low temperature and common terminal. Relay should pull in.
2. Remove jumper. Relay should drop out.

Observe system operation for one automatic cycle. Make certain that system comes on and turns off in response to the R7412 Differential Temperature Controller. Check for proper operation of freeze and over. temperature protection and of controlled equipment such as circulators and valves.

Shorting out the high and common terminals will simulate a freeze condition.

Shorting out the common and low terminals will simulate an overtemperature condition. 


\section{OPTIONAL APPLICATIONS}

In addition to the differential temperature control, the $\mathrm{R} 7412 \mathrm{~A}$ can serve as a single function temperature controller such as a. high temperature limit or an Aquastat. The R7412A is adapted to these functions by changing the $\mathrm{ON}$ and $\mathrm{OFF}$ resistors and the sensor connections. When changing functions, use $1 / 8$ watt, 1 percent resistors, available locally.

Use the following procedures to change the factory. set differential temperature controller to a single function temperature controller as indicated in Figs. 10 and 11 .

1. Remove cover. Remove the OFF resistor and replace with an $11,500 \mathrm{ohm}$ resistor according to resistor preparation shown in Fig. 9.

2. To adjust the temperature differential, remove the $\mathrm{ON}$ resistor and select a resistor value according to Table 1. Install the selected resistor.

3. To adjust the temperature setpoint, select a resistor value according to the graph in Fig. 12. Connect the selected setpoint resistor to the low temperature and common terminals for make on temperature rise control (Fig. 10). Connect to high and common terminals for make on temperature fall.

4. Wire the sensor to the high temperature and common terminals for make on temperature rise; wire the sensor to the low temperature and common terminals on temperature fall.

5. Check the resistors for proper location and value. Replace the cover.

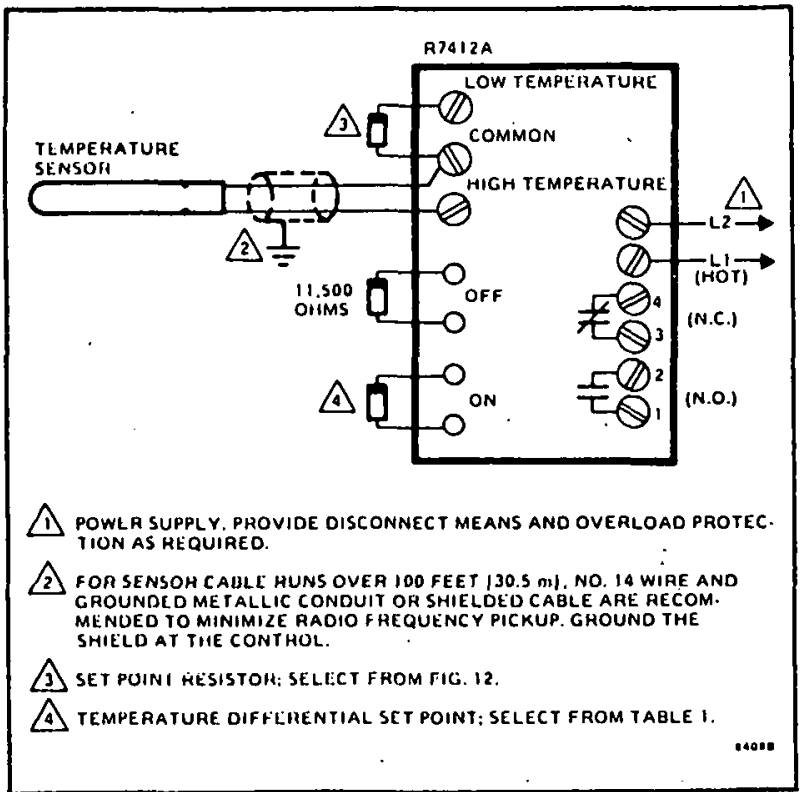

FIG. 10-SINGLE FUNCTION SET POINT CONTROL. CONTROL MAKES ON TEMPERATURE RISE TO SET POINT PLUS DIFFERENTIAL, BREAKS ON TEMPERATURE FALLTOSET POINT.

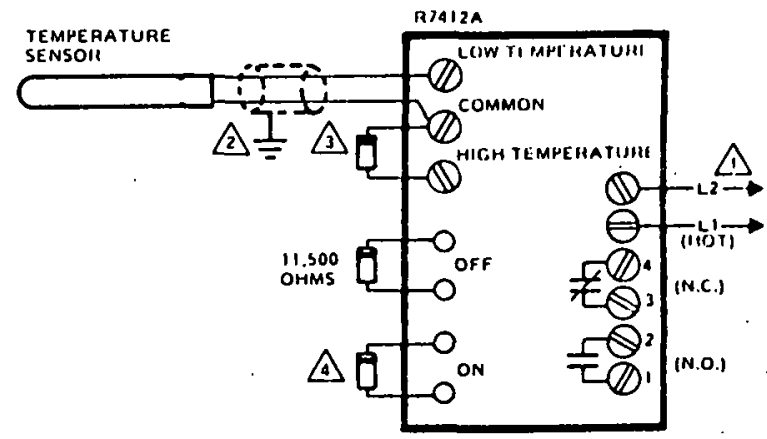

A POWER SUPPLY. PROVIDE DISCONNECT MEANS AND OVEHLOAD PRO TECTION AS REQUIREO.

2 FOR SENSOR CABLE RUNS OVER 100 FEET $130.5 \mathrm{ml}$ : NO. 14 WIRE ANO GOUNDED METALLIC CONDUIT ON SWET J JOS

A SET POINT RESISTOR; SELECT FROM FIG. 12.

A. TEMPERATURE difFerential SET POINT: SELECT From table I.

FIG. 11-SINGLE FUNCTION SET POINT CONTROL. CONTROL MAKES ON TEMPERATURE FALL TO SET POINT MINUS DIFFEREN. TIAL, BREAKS ON TEMAPERATURE RISE TO SET POINT.

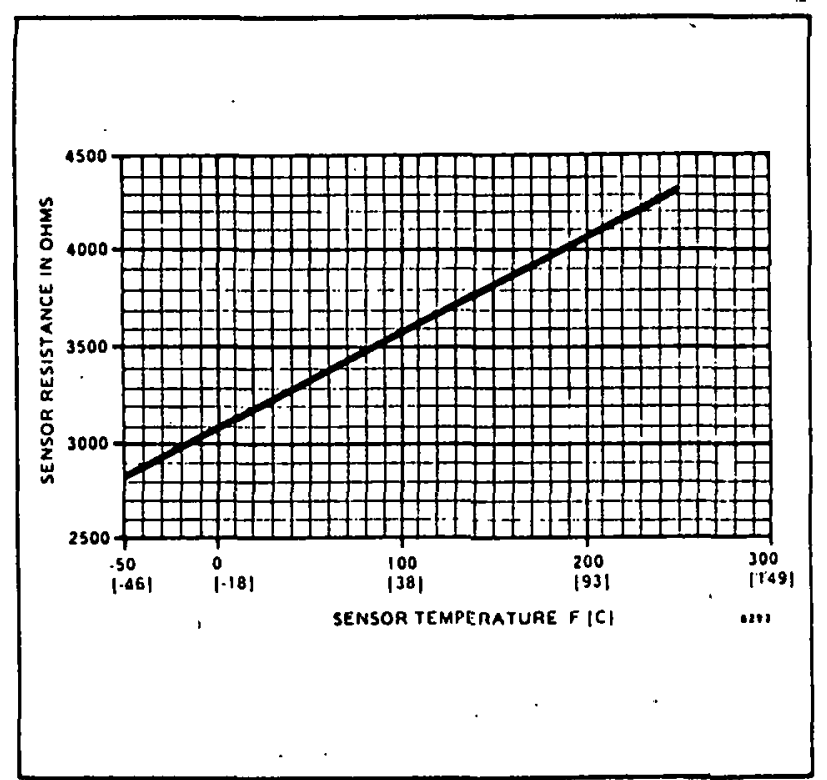

FIG. 12-R7412A SINGLE FUNCTION TEMPERATURE SET POINT. CHOOSE A RESISTANCE ACCORDING TO THE DESIRED SET POINT.

HONEYWELL MINNEAPOLIS, MINN. 55408 INTE.RNATIONAL Sales Offices in all principal cities of the world. Manufacturing in Australia, Canada, Finland, France, Germany, Japan, Mexico, Netherlands, Spain, Taiwan, United Kingdom, U.S.A. 
THE T675 AND T678 TEMPERATURE CON. TROLLERS REGULATE THE TEMPERATURE OF AIR OR LIQUIDS IN DUCTS, PIPES, AND TANKS. TYPICAL USES INCLUDE CONTROL OF DAMPERS AND VALVES IN HEATING, COOLING, OR HEATING-COOLING SYS"TEMS.

T675A High Limit Controller makes a circuit on a rise in temperature.

口 T675B Low Limit Controller makes a circuit on a decrease in temperature.

口 T678A Low Limit Controller makes two independent circuits in sequence on a decrease in temperature.

$\square$ Fast response models with adjustable differential available.

$\square$ Ambient temperature compensated.

Setting knob on front.

Sensing element may be mounted up to 20 fect from controller case.

E.S.

REV. 11.75
FORM 60-2200 -1

RESIDENTIAL DIV.
TEMPERATURE CONTROLLERS

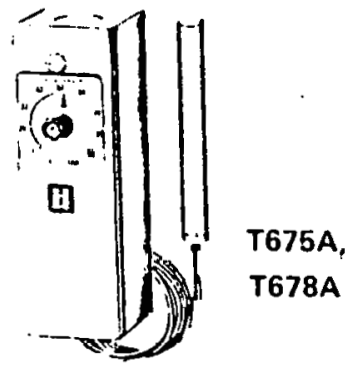

T675B
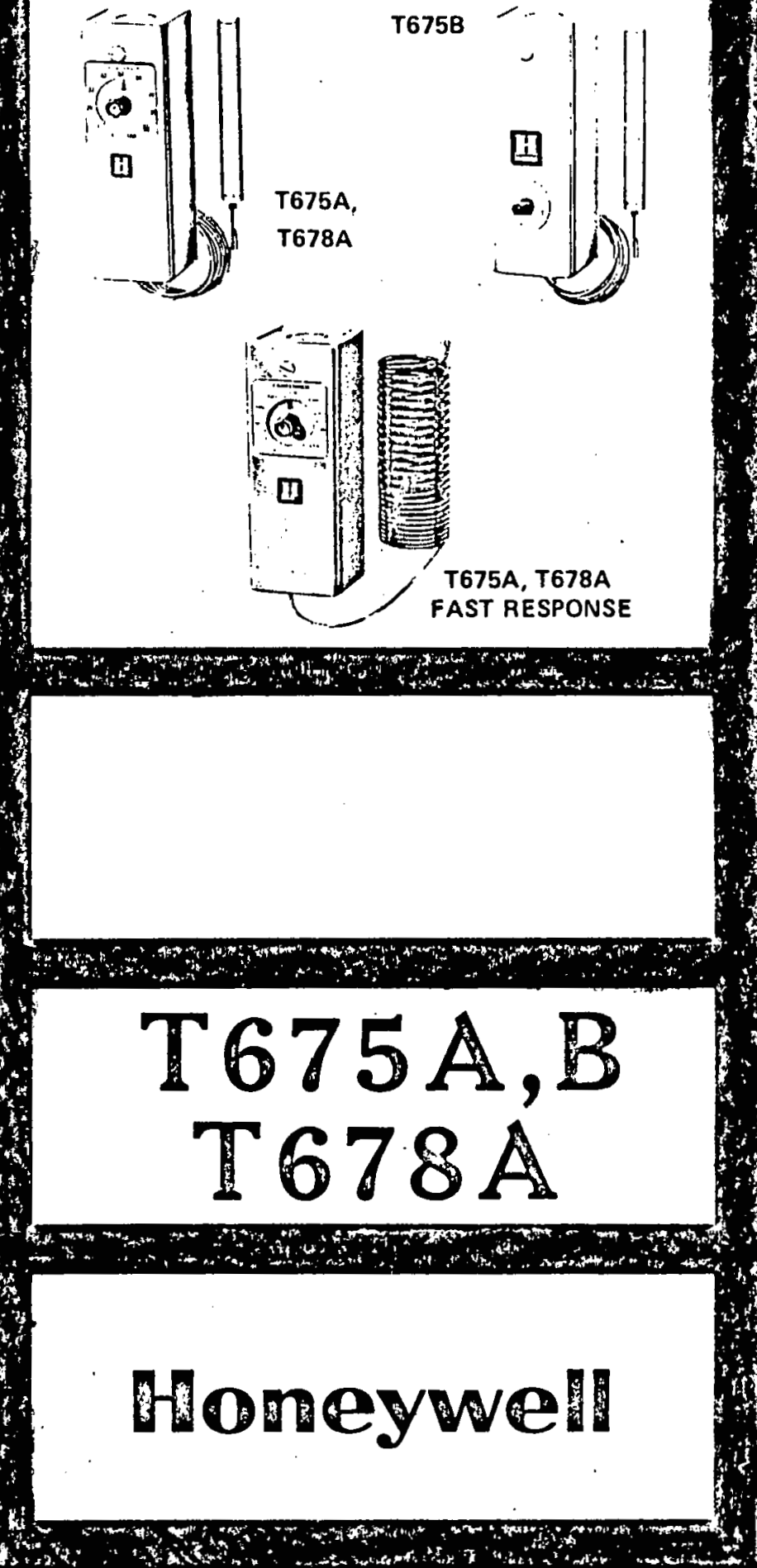
MODELS (also refer to Table I):

T675A Temperature Controller - spdt switching to make or break a circuit on a temperature change; fast response models operate approximately seven times faster than standard models.

T675B Low Limit Temperature Controller breaks a circuit on a temperature fall; must be manually reset.

T678A Temperature Controller - two spdt switches operate two independent circuits in sequence; fast response models operate approximately seven times faster than standard models.

TABLE I

\begin{tabular}{c|c|c|c}
\hline \hline $\begin{array}{c}\text { MODEL } \\
\text { NO. }\end{array}$ & RANGE & MAX. & SWITCHING \\
\hline & 0 to $100 \mathrm{~F} /-15$ to $35 \mathrm{C}$ & $125 \mathrm{~F}$ & \\
T675A & 55 to $175 \mathrm{Fa} / 15$ to $75 \mathrm{C}$ & $200 \mathrm{~F}$ & \\
& 80 to $180 \mathrm{~F} / 30$ to $80 \mathrm{C}$ & $200 \mathrm{~F}$ & spdt \\
& 160 to $260 \mathrm{~F} / 75$ to $125 \mathrm{C}$ & $280 \mathrm{~F}$ & \\
\hline T675Bb & 30 to $50 \mathrm{~F}$ & $125 \mathrm{~F}$ & spst \\
\hline & 0 to $100 \mathrm{~F}^{\mathrm{a}} /-15$ to $35 \mathrm{C}$ & $125 \mathrm{~F}$ & \\
& 55 to $175 \mathrm{~F} / 15$ to $75 \mathrm{C}$ & $200 \mathrm{~F}$ & \\
T678A & 80 to $180 \mathrm{~F} / 30$ to $80 \mathrm{C}$ & $200 \mathrm{~F}$ & two spdt \\
& 160 to $260 \mathrm{~F} / 75$ to $125 \mathrm{C}$ & $280 \mathrm{~F}$ & \\
\hline
\end{tabular}

aAvallable with fast response sensing element.

b $675 \mathrm{~B}$ scale is marked $30,40,50$; set point is factory set and locked at $37 \mathrm{~F}$.

\section{SWITCH DIFFERENTIALS:}

T675A-fixed differential models $-1 \mathrm{~F}(.6 \mathrm{C})$; adjustable models -3 to $10 \mathrm{~F}(1.7$ to $5.6 \mathrm{C})$; fast response models-3.6 to $12 \mathrm{~F} \mathrm{(2} \mathrm{to} 6.6 \mathrm{C}$ ). T675B-fixed $10 \mathrm{~F}(5.6 \mathrm{C})$.

T678A-flxed $3 \mathrm{~F}$ per switch with adjustable interstage 3 to $10 \mathrm{~F}(1.7$ to $5.6 \mathrm{C})$;

models with 55 to $175 \mathrm{~F}$ scale-fixed $3.6 \mathrm{~F} \mathrm{(2} \mathrm{C)}$ per switch with adjustable interstage 3.6 to $12 \mathrm{~F}$ $(2$ to $6.6 \mathrm{C})$.
ELECTRICAL RATINGS:

T675A adjustable models and T678A:

\begin{tabular}{l|c|r}
\hline & $120 \mathrm{v} \mathrm{ac}$ & $240 \mathrm{v} \mathrm{ac}$ \\
\hline Full Load & 8.0 & 5.1 \\
\hline Locked Rotor & 48.0 & 30.6 \\
\hline
\end{tabular}

T675A nonadjustable models, 125 va at $120 / 208$ / 240v ac.

T675 B 125 va at $240 \mathrm{v}$ ac pilot duty.

MAXIMUM AMBIENT OPERATING TEMPERATURE: $125 \mathrm{~F}$.

NOTE: The maximum recommended ambient for the T675B, when used for freeze-up protection, is $100 \mathrm{~F}$. An ambient of $125 \mathrm{~F}$ lowers the switch break point about $1.5 \mathrm{~F}$.

BULB SIZE: $1 / 2 \times 4-3 / 16$ inches for 0 to $100 \mathrm{~F}$ models; $1 / 2 \times 3-9 / 16$ inches for other scale ranges.

MAXIMUM BULB PRESSURE: 50 psig direct immersion.

\section{CAPILLARY LENGTH AND MATERIAL:}

T675A, T678A standard response models -5 or 20 foot copper, or 20 foot Monel or stainless steel.

T675A, T678A fast response models -5 foot copper with the sensing portion of element $1-1 / 2$ inch dia. $x$ 5 inches long (coiled 1/8 inch tubing). The coil may be stretched to approximately 10 inches.

T675B-10 foot copper.

CAPILLARY HOLDER: Honeywell part 131524A included with all fast response models.

(continued on poge 3)

\section{ORDERING INIFORMATION}

WHEN ORDERING REFER TO THE TRADELINE CATALOG OR PRICE SHEETS FOR COMPLETE ORDERING SPECIFICATION NUMBER, OR...

SPECIFY-

1. MODEL NUMBER.

2. SCALE RANGE.

3. STANDARD OR FAST RESPONSE MODEL.

4. CAPILLARY LENGTH AND MATERIAL.

6. FIXED OR ADJUSTABLE DIFFERENTIAL ON T675A.

6. ACCESSORIES, IF DESIRED.
ORDER FROM-

1. YOUR USUAL SOURCE, OR

2. HONEYWELL

1885 DOUGLAS DRIVE, NORTH

MINNEAPOLIS, MINNESOTA 55422

IIN CANADA-HONEYWELL CONTROLS LIMITED

740 ELLESMERE ROAD

SCARBOROUGH, ONTARIO) 
LISTING BODIES: Listed by Underwriters' Laboratories, Inc.

\section{ACCESSORIES:}

1. Separable immersion wells; short necked, $1 / 2$ inch NPT, copper - order 112622AA. For additional information on immersion wells see Honeywell Tradeline Catalog.

2. Pressure fitting rated at 50 psi water or 15 psi air-order 7617ABY. For additional information on pressure fittings see Honeywell Tradeline Catalog.

3. Duct bulb holder 311266 ; also refer to Honeywell Tradeline Catalog.

4. T-strap 105900 for strapping the bulb to a pipe.

5. Bag assembly $7617 \mathrm{ABZ}$ with bracket for mounting the controller to fan coil units.

6. Calibration wrench 801534 .

7. Bag assembly $7640 \mathrm{HY}$ with standoff bracket for mounting the controller to an insulated duct.

8. Q615A weatherproof enclosure.

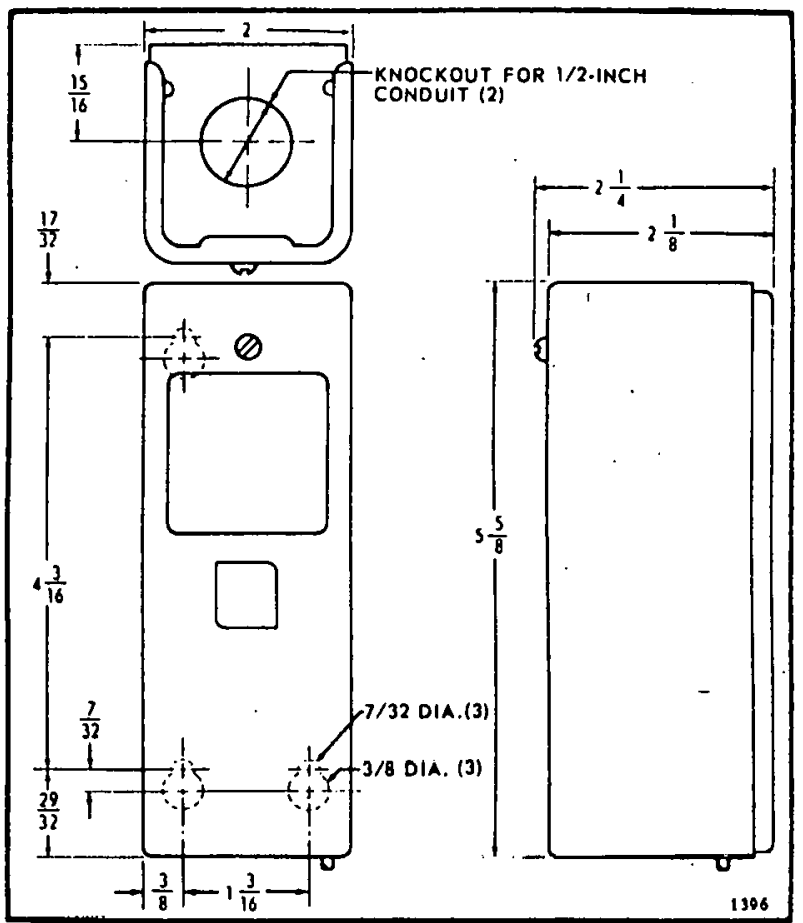

FIG. 1-DIMENSIONS (IN INCHES) Or TG7S AND T678 CON. TROLLERS.

\section{INSTALLATION}

\section{CAUTION}

1. Dlsconnect power supply before making wiring connections to prevent electrical shock and equipment damage.

2. Installer must be a trained, experlenced serviceman.

3. Always conduct a thorough checkout when installation is complete.

\section{LOCATION AND MOUNTING}

The controller may be installed in any convenient position. Be sure to consider the length of the capillary before mounting controller.

Install the sensing element where it is exposed to the average temperature of the controlled medium. T675A fast response models must use the caplllary holder furnished with the device. The sensing bulb of standard models should be held in place with a bulb holder, Immersion well, or pressure fittings. (See Higs. 2-4.) Sharp bends or kinks in the capillary tubing affect the efficlency of the controller and must be avoided. Excess capillary should be carefully coiled and left directly beneath the controller.

NOTE: When pressure fittings are used in areas of vibration such as pipe lines, the bulb must be adequately supported.

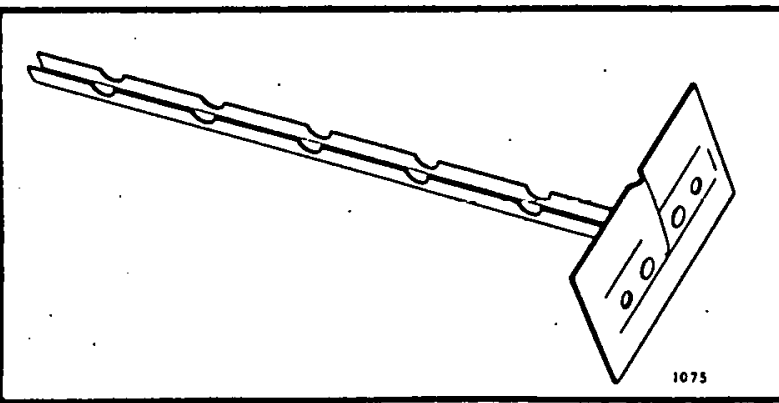

FIG. 2-BULB HOLDER FOR MOUNTING SENSING ELEMENT.

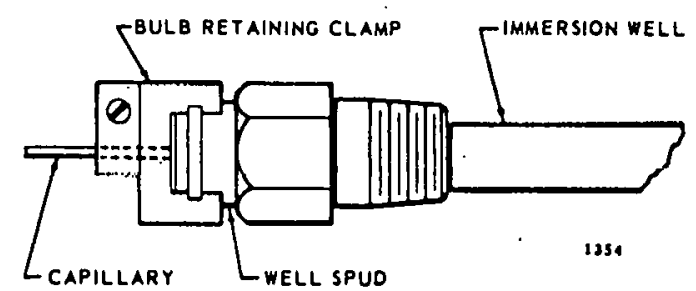

FIG. 3-IMMERSIUN WELL ASSEMBLY FOR MOUNTING SENS ING BULB.

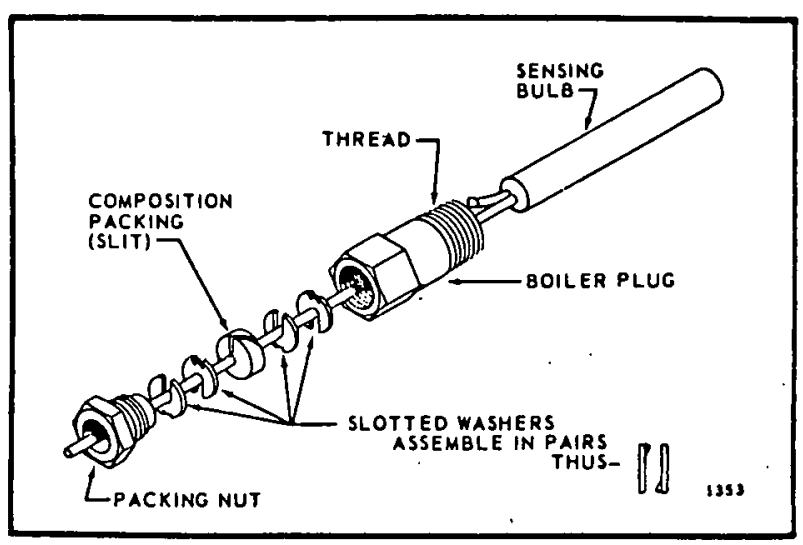

FIG. 4-COMPRESSION FITTING FOR PRESSURE TIGHT MOUNTING OF SENSING ELEMENT. 


\section{WIRING}

All wiring must comply with local electrical codes and ordinances.

\section{CAUTION}

Disconnect the power supply before proceeding with wiring.

Two knockouts for $1 / 2$ inch conduit are provided, one at top and one at bottom of case. Follow the wiring instructions furnished with the heating or cooling system. Fig. 5 shows the switching action.

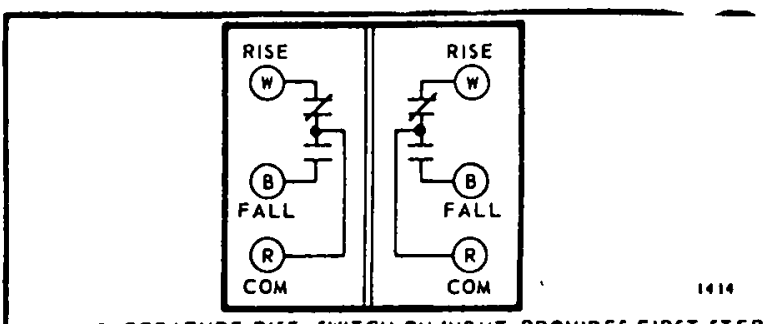

ON TEMPERATURE RISE, SWITCH ON KIGHT PROVIOES FIRST STEP SWITCHING; SWITCH ON LEFT PROVIDES SECOND STEP SWITCHING.

FIG. 5-T678A SWITCHING ACTION. T675A IS SIMILAR BUT HAS ONLY ONE SPDT SWITCH. T675B HAS ONE SPST SWITCH.

\section{OPERATION}

\section{T675A}

As the temperature of the controlled medium falls below the set point, less differential, the T675A switches to make terminals $R$ to $B$ and energize a normally closed solenold valve to provide heat. In cooling applications, the T675A makes terminal $R$ to $W$ as the temperature rises above the set point and energizes cooling equipment. Fig. 7 shows the operation of the T'675A.

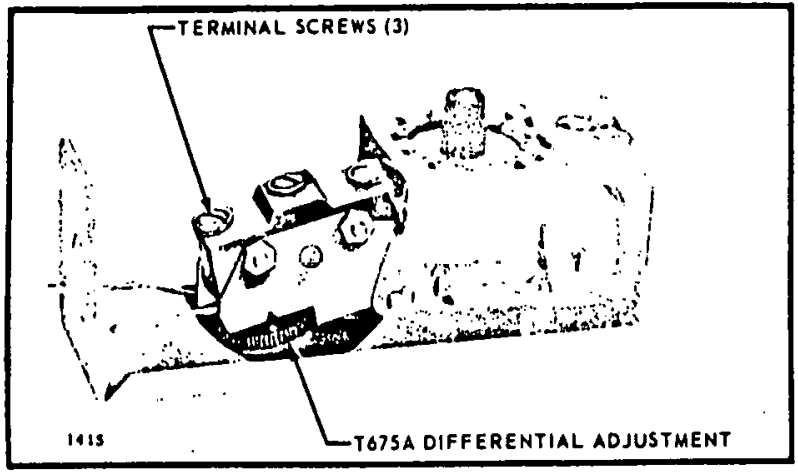

FIG. 6-INTERNAL VIEW OF T675A SHOWING THE SWITCH DIFFERENTIAL ADJUSTMENT WHEEL (APPLICABLE MODELS).

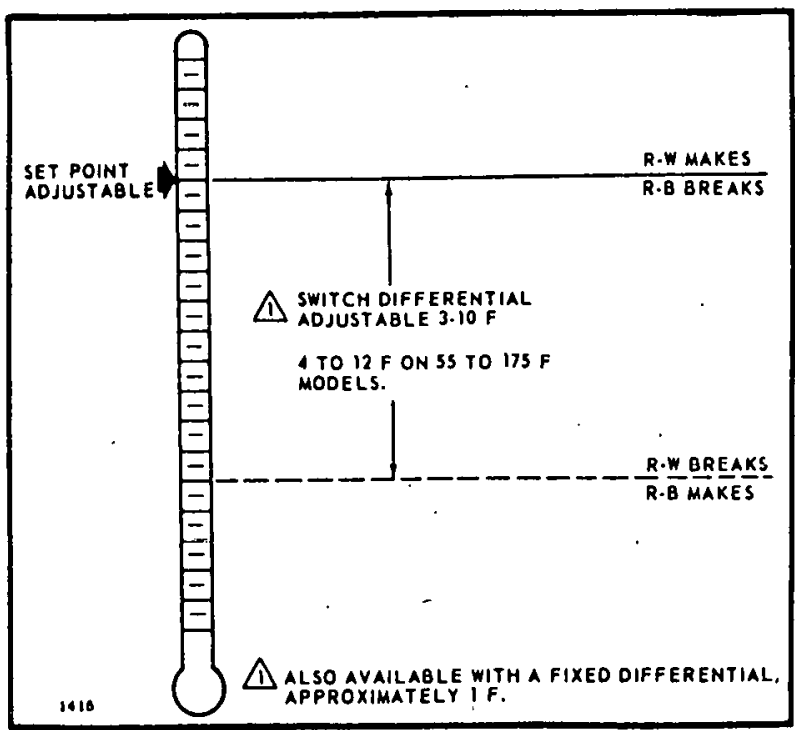

FIG. 7-DIFFERENTIAL ADJUSTMENT RANGE OF T675A.

\section{FREEZE-UP PROIECTION}

When using the T675A (auto-recycling) for freezeup protection, the recommended set point is $38 \mathrm{~F}$ plus the switch differential.

example: SET POINT $38 \mathrm{~F}$, plus $1 \mathrm{~F}$ (fixed differential model) equals an actual set point of $39 \mathrm{~F}$.

example: SET POINT $38 \mathrm{~F}$, plus $3 \mathrm{~F}$ (adjustable differential model) equals an actual set point of $41 \mathrm{~F}$.

This ensures adequate safety factor for freeze-up protection.

NOTE: The T675B is a manual reset device and is specifically designed for freeze-up protection.

\section{8}

Used as a low limit controller, the T675B inter rupts the operation of equipment if the temperature of the controlled medium falls below a predetermined limit. The device is reset manually after a rise in temperature of approximately $10 \mathrm{~F}$. The operation of T675B is shown graphically in Fig. 8.

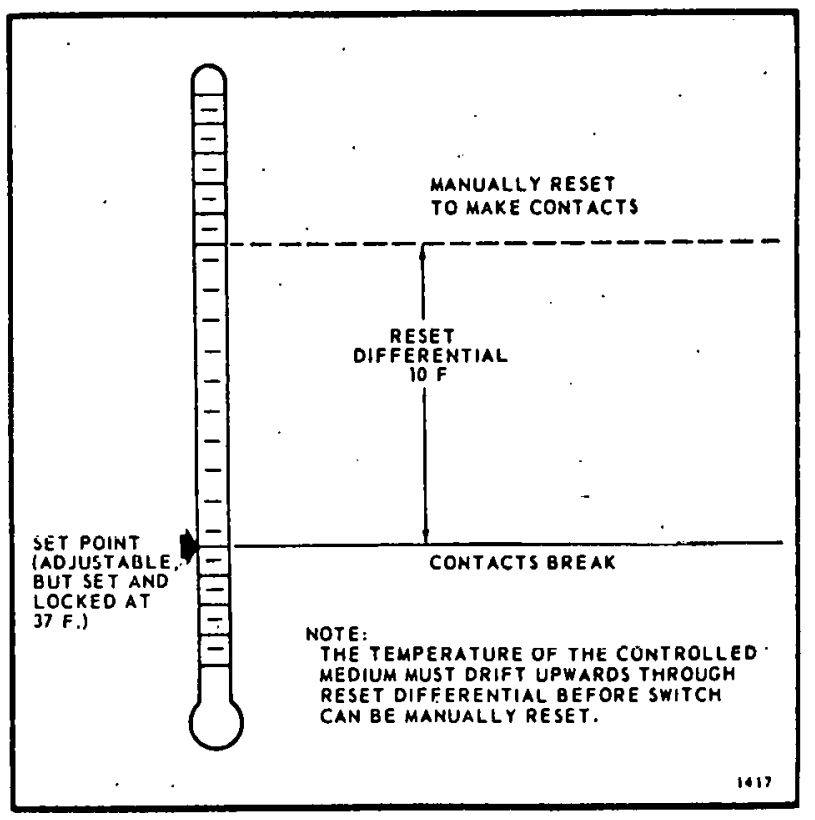

FIG. 8-DIFFERENTIAL ADJUSTMENT RANGE OF T675B. 
When the temperature at the sensing bulb rises above the setting of the controller, the switch on the right completes a circuit between the $R-W$ terminals of that switch. Should the temperature continue to rise through the preselected interstage differential of the controller, the switch on the left will complete its $\mathrm{R}-\mathrm{W}$ circuit.

Conversely, on a temperature fall the switch on the left provides first step switching. If the temperature continues to fall, the switch on the right completes its $R-B$ circuit to provide sequencing of equipment.

Each T678 has a between-switch differential adjustment. Make this adjustment by inserting a narrow screwdriver into the rectangular hole in the chassis (See Fig. 9) and pushing the star wheel. At its maximum position, interstage differential is $10 \mathrm{~F}$. At minimum position differential is $3 \mathrm{~F}$. Adjust until satisfactory operation is achieved.

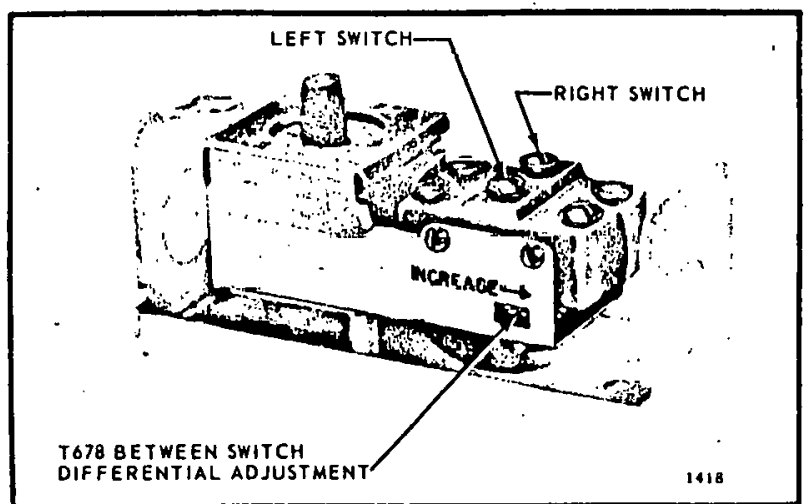

FIG. 9-INTERNAL VIEW OF T678A SHOWING THE BETWEEN SWITCH DIFFERENTIAL ADJUSTMENT.
The T678A Temperature Controller may be adjusted to give an interstage differential of three to ten degrees above the set point. The set point adjustment dial determines the temperature at which the right switch operates. The operation of the left switch is adjustable from three to ten degrees above that point of operation. An illustration depicting the operation of the T678A is shown in Fig. 10.

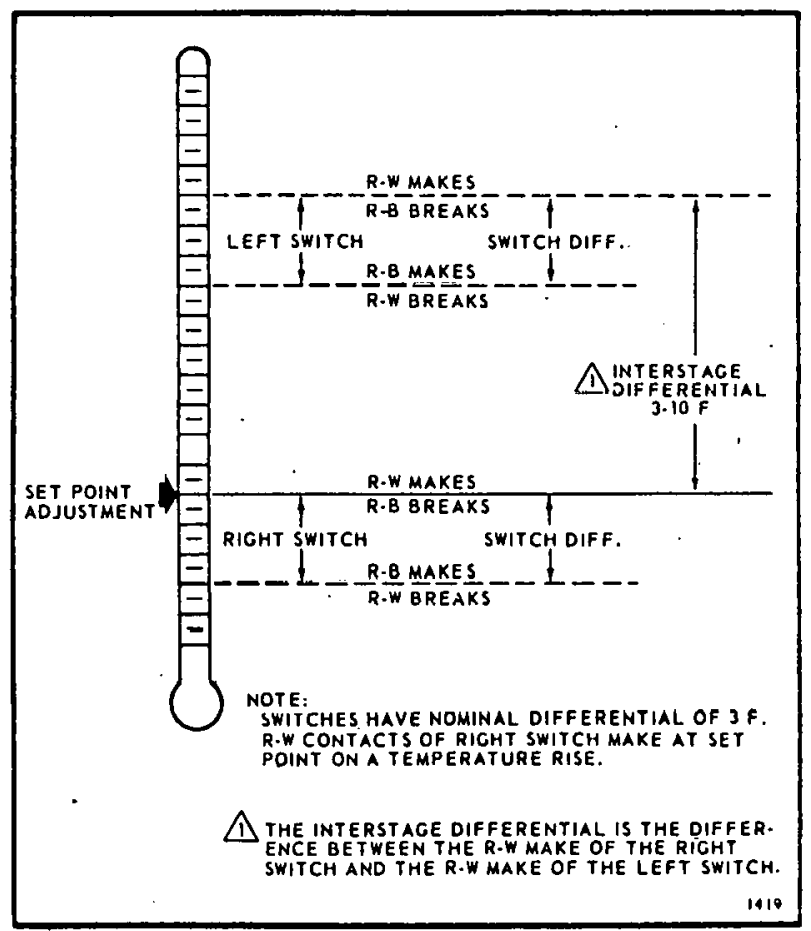

FIG. 10-DIFFERENTIAL ADJUSTMENT RANGE OF T678A.

\section{CALIBRAIION}

All controllers are carefully tested and calibrated at the factory under controlled conditions. If the controller is not operating at a temperature corresponding to the scale setting and differential setting, check to see that the bulb senses the average temperature of the medium controlled. If the temperature of the controlled medium is changing rapidly the differential will appear wider than its setting.

For calibration, an accurate temperature reading of the controlled medium must be taken. Place an accurate thermometer near the bulb of the controller, or refer to a thermometer that has been installed as part of the system. If the bulb of the controller is installed in an inaccessible area, or if the controlled medium is unstable, it should be removed and placed in a controlled bath for accurate calibration.

\section{4}

These controllers are calibrated so that the dial setting is the point at which the R-W switch contacts make on a temperature rise. Measure the tempera- ture at the bulb. Rotate the dial counterclockwise 7 from the top of the scale, simulating a temper * ature rise, until the $\mathrm{R}-\mathrm{W}$ switch contacts make. Note the dial reading. If it differs from the set point, calibrate the dial as follows:

1. Determine the number of degrees difference between the set point and the point at which the contacts make.

2. Remove the dial knob and slip the fingers of the calibration wrench into the slots of the dial. Rotate the dial until the fingers of the wrench drop into the slots of the calibration nut under the dial. Note the dial indication at this point. Turn the dial and the calibration nut up or down scale the number of degrees that the set point differs from the point at which the contacts make (determined in step 1). For example, move dial from 45 to 65 degrees for a 20 degree change in calibration.

3. Check the calibration adjustment by moving the dial up and down the scale while watching the contacts make and break. If dial is still out of calibration, repeat calibration procedure. 
These controllers are calibrated so that the dial setting is the point at which the switch contacts break on a temperature fall. Measure the temperature at the bulb. Rotate the dial clockwise $\rightarrow$ from the bottom of the scale to simulate a temperature fall until the switch contacts break. Note the dial reading.

If it differs from the set point, follow the callbration procedure outlined for the T675A.

\section{T678A}

These controllers are calibrated so that the nonadjustable (right hand) switch makes on a temperature rise and the adjustable (left hand) switch makes 3 to $10 \mathrm{~F}$ higher. The point at which the nonadjustable switch makes represents the dial setting. Rotate the dial reading. Continue rotating the dial until the left hand switch makes. The difference between the two readings is the interstage differential. The left hand switch must make at a lower reading than the right hand switch. Adjust the differential if necessary. Changing the differential may change the calibration.

Measure the temperature at the bulb. Rotate the dial counterclockwise from the top of the scale to simulate a temperature rise until the contacts of the left hand switch make. Note the reading.

If it differs from the set point, follow the procedure outlined for the T675A.

\section{CHECROUT:}

Check the operation of the controller by raising and lowering the set point through the temperature range of the air or liquid being controlled. Make sure that controlled equipment operates as intended. 
T991A Proportional Temperature Controllers provide modulating control of water or air tem. peratures in ducts, tanks, and similar applications. Standard models have a sensing bulb and capillary; fast response models have a coiled sensing element that operates at least four times faster than standard controllers, depending upon operating conditions.

$\square$ All models compensate for effects of ambient temperature on the case and tubing.

\section{Controls temperature of air or liquids.}

Sensing element capillary tubing allows remote mounting of sensing element.

$\square$ Set point may be read and adjusted through cover.

Throttlingdial inside case adjusts proportioning range.

PROPORTIONAL TEMP足合TUR定 CONTROLLERS

RESPONSE
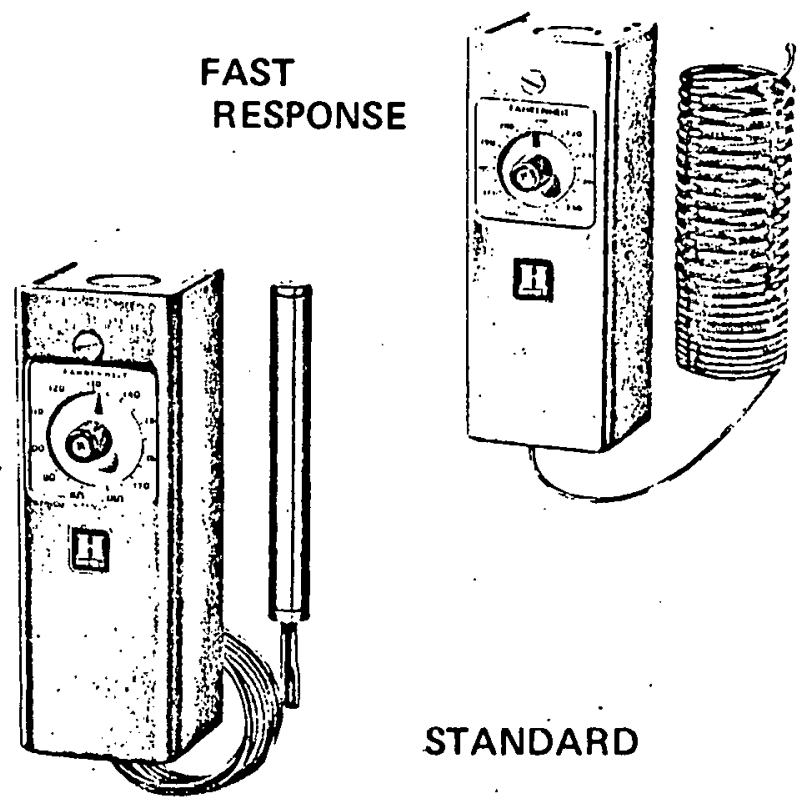

STANDARD

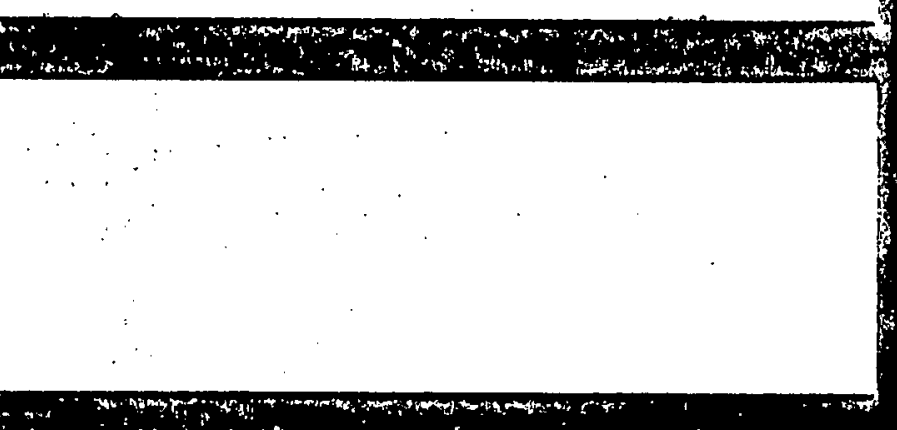

\section{$\mathbb{T} 991 \mathbb{A}$}




\section{SPECIIFICATIONS}

MODELS: T991A Temperature Controller-standard or fast response.

ELECTRICAL RATING: 24 to $30 \mathrm{v}$ ac.

POTENTIOMETER RESISTANCE: $135 \mathrm{ohms}(280 \mathrm{ohms}$ available as option on model with 55 to $175 \mathrm{~F}$ range).

TEMPERATURE RANGES AND LIMITS:

\begin{tabular}{c|c|c}
\hline \hline Range & $\begin{array}{c}\text { Maximum Ambient } \\
\text { Temperature for } \\
\text { Controller }\end{array}$ & $\begin{array}{c}\text { Maximum Operating } \\
\text { Temperature for } \\
\text { Bulb }\end{array}$ \\
\hline 0 to $100 \mathrm{~F}$ & & $125 \mathrm{~F}$ \\
55 to $175 \mathrm{~F}^{\mathrm{a}}$ & & $200 \mathrm{~F}$ \\
80 to $180 \mathrm{~F}$ & $125 \mathrm{~F}$ & $200 \mathrm{~F}$ \\
160 to $260 \mathrm{~F}$ & & $280 \mathrm{~F}$ \\
\hline-15 to $35 \mathrm{C}$ & & $52 \mathrm{C}$ \\
15 to $75 \mathrm{C}$ & & $93 \mathrm{C}$ \\
30 to $80 \mathrm{C}$ & $52 \mathrm{C}$ & $93 \mathrm{C}$ \\
75 to $125 \mathrm{C}$ & & $138 \mathrm{C}$ \\
\hline
\end{tabular}

${ }^{\text {a Avallable in } 20 \mathrm{ft} \times 7 / 64}$ O. D. averaging element (copper)-senses temperature along length of element.

PROPORTIONING RANGE: Adjustable from approximately 3 to 30 degrees $F$ ( 1.7 to 17 degrees C); set point is always the center point of promertioning range.

BULB PRESSURE RATING: 50 psi maximum for direct immersion.

CAPILLARY LENGTH AND MATERIAL (5/64 inch O.D.):

Copper: 5, 10, 20, or 24 feet.

Stainless steel: 20 feet.

MOUNTING MEANS: Three holes in back of case for furnished screws.

DIMENSIONS: See Fig. 1.

FINISH: Gray.

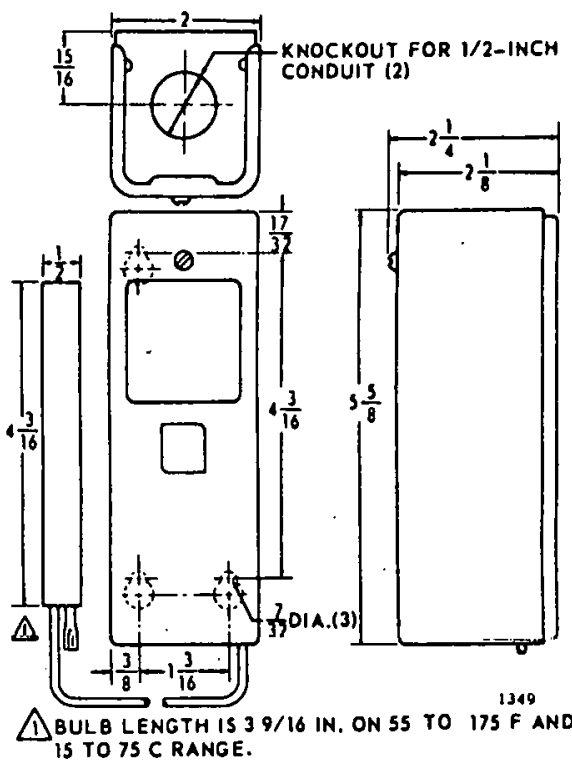

FIG. 1-APPROXIMATE DIMENSIONS IN INCHES

\section{ACCESSORIES:}

1. Separable immersion wells, to be screwed into tank or boiler: 112622AA-1/2 inch NPT, or 112630AA $-3 / 4$ inch NPT.

2. Pressure fitting $7617 \mathrm{ABY}-1 / 2$ inch NPT, rated at $50 \mathrm{psi}$ water or $15 \mathrm{psi}$ air pressure.

3. Duct Bulb Holder 107324A.

Duct Cull Holder 131524A.

4. T-Strap 105900 for strapping bulb to a plpe.

5. Bracket assembly $7640 \mathrm{HY}$ (a standoff bracket for mounting T991A to insulated duct).

6. Assembly $7640 \mathrm{HX}$ for mounting T991A with averaging element when access into duct is not available.

7. Calibration wrench 801534 .

8. Weatherproof enclosure Q615A.

\section{OPTIONAL SPECIFICATIONS:}

1. 280 ohm potentiometer on 55 to $175 \mathrm{~F}$ model.

2. Averaging element available on 55 to $175 \mathrm{~F}$ model or 15 to $75 \mathrm{C}$ model.

\section{ORDERING INIFORMATION}

WHEN ORDERING REFER TO THE TRADELINE CATALOG OR PRICE SHEET FOR COMPLETE ORDERING SPECIFICATION

NUMBER, OR. .

SPECIFY-

1. MODEL NUMBER

2. SCALE RANGE.

3. CAPILLARY LENGTH AND MATERIAL.

4. OPTIONAL SPECIFICATIONS OR ACCESSORIES IF DESIRED.

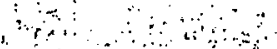

IIN CANADA-HONEYWELL CONTROLS LIMITED 740 ELLESMERE ROAD SCARBOROUGH, ONTARIO 
CAUTION: Disconnect power supply.

Installation should be made only by a qualified serviceman. Follow instructions of system manufacturer, if available.

\section{LOCATION}

The T991A may be mounted in any convenient position on a flat surface where the ambient temperature does not exceed $125 \mathrm{~F}$. When mounting on a hot or cold surface, mount the case on a wood board or other insulating material. The capillary tube provides for remote mounting.

\section{MOUNTINO}

On replacement applications, mount the T991A in place of old control if requirements under LOCATION above, are met. Mount case according to instruc tions below. Use old sensing bulb hole, bulb holder, immersion well, or compression fitting if these are suitable; otherwise, follow the instructions below for new applications.

\section{MOUNT THE CONTROLLER CASE:}

1. Remove cover. Using the case as a template, mark three screw hole locations on mounting surface, llien punch ur drill hules.

2. Fasten T991A securely to mounting surface with the furnished mounting screws.

TO INSTALL SENSING BULB IN AIR DUCT:

Locate the sensing bulb where duct air of average temperature can circulate freely around it. Avoid mounting the bulb close to hot pipes, cooling coils, and other places where air temperatures are not representative.

To support the bulb in the duct, use bulb holder accessory (see Fig. 2).

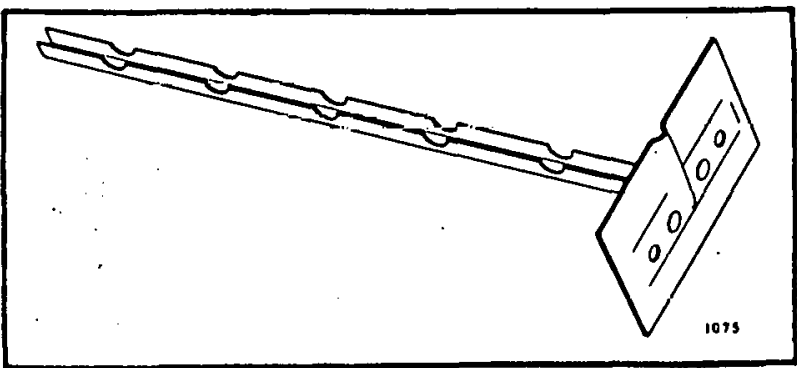

FIG. 2-BULB HOLDER.

1. Drill a $3 / 4$ inch hole in the duct wall to admit the sensing bulb and holder.

2. Using the holder as a template, mark and drill holes for bulb holder mounting screws.

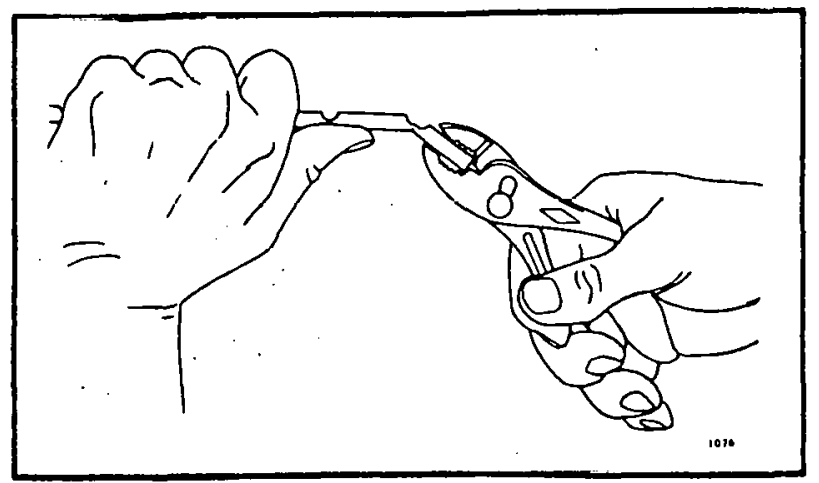

FIG. 3-SHORTENING THE BULB HOLDER.
3. Break off bulb holder to desired length, as shown in Fig. 3. NOTE: Holder should be long enough to hold sensing bulb in freely circulating air, away from duct wall. Neatly coil any excess capillary tubing at controller case or at bulb holder.

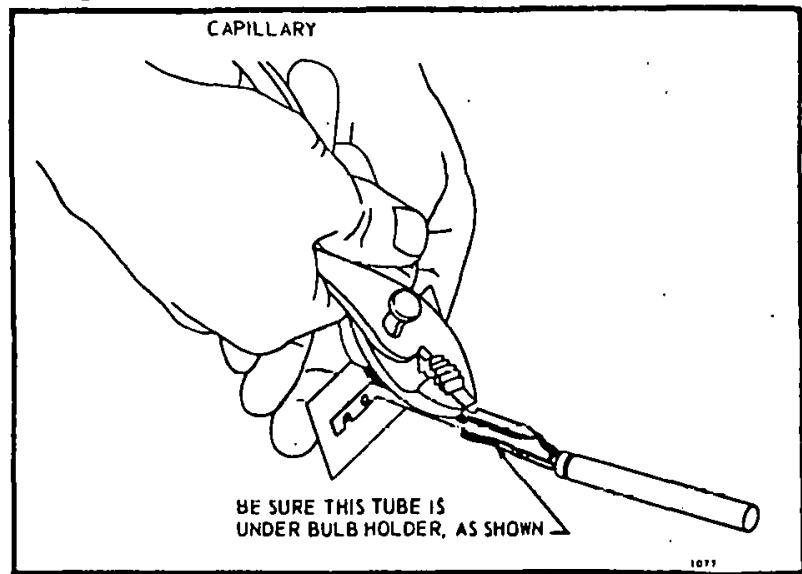

FIG. 4-INSERTING CAPILLARY TUBING IN HOLDER.

4. Place capillary tubing in bulb holder channel, and pinch top edges of holder together at each segment, as shown in Fig. 4.

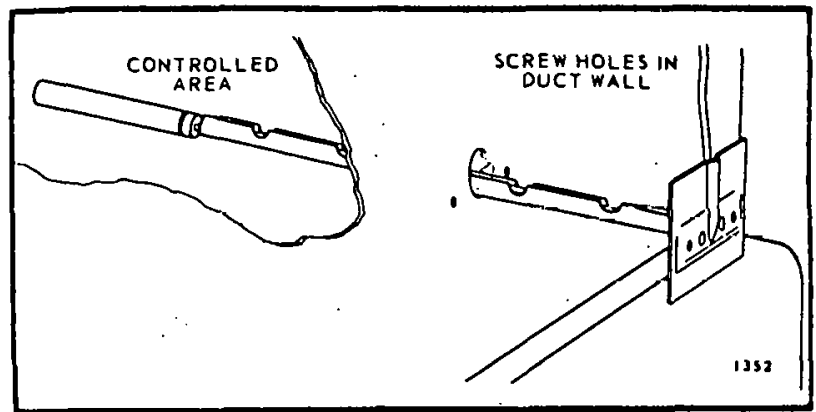

FIG. 5-INSFRTION INTO DUCT.

5. Insert bulb and holder into controlled area through hole prepared in Step 1 (Fig. 5).

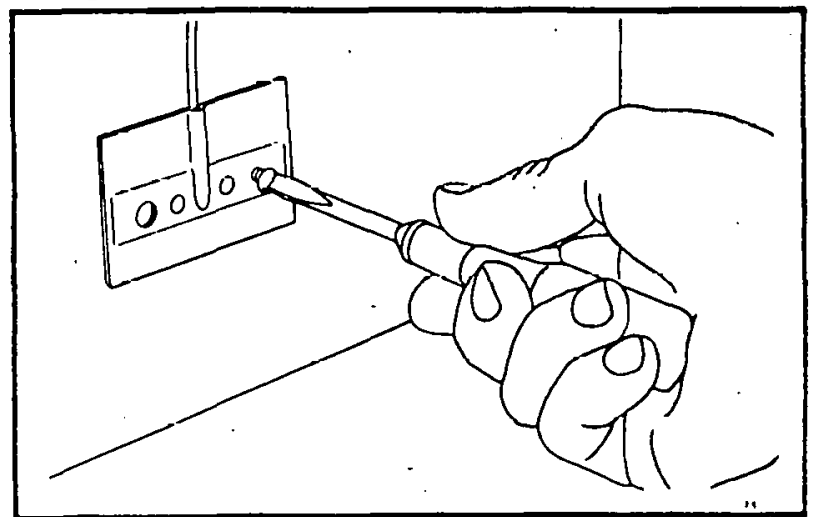

FIG. 6-FASTENING HOLDER TO DUCT WALL.

6. Fasten bulb holder to duct wall with screws furnished, as shown in Fig. 6 .

TO INSTALL A FAST RESPONSE MODEL:

Use duct holder assembly for the sensing coil. Drill a 1-5/8 inch hole in the duct wall to receive the whole coil, and then use the mounting procedure for the standard model. WARNING: Do not stretch the coil more than eight inches on the holder. 
TO INSTALI SENSING BULB IN TANK OR BOILER:

The bulb may be inserted directly into 2 tank or boiler tapping by means of a pressure fitting (see ACCESSORIES), or the bulb may be inserted into an immersion well that is screwed into the tank or boiler (see ACCESSORIES).

To install pressure fitting:

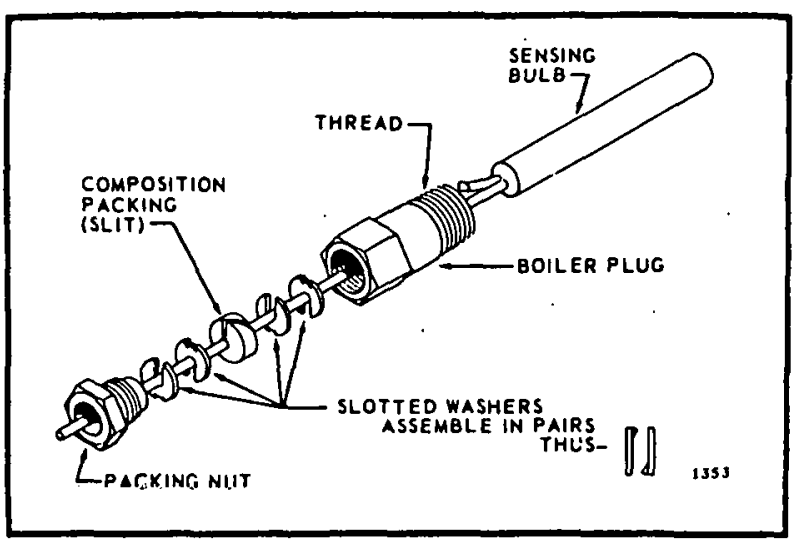

FIG. 7-PRESSURE FITTING ASSEMBLY.

1. Drain system, and screw boiler plug into properly sized and threaded boiler or pipe tapping (1/2-14 NPT).

2. Place packing nut on T991A capillary tube.

3. Slide sensing bulb completely through boiler plug.

4. Place composition disc and the four slotted brass washers on tubing in the order shown in Fig. 7.

5. Slide the assembly into the boiler plug, and tighten the packing nut.

6. Refill the system and check for leaks, Neatly coil excess capillary tubing at T991A case.

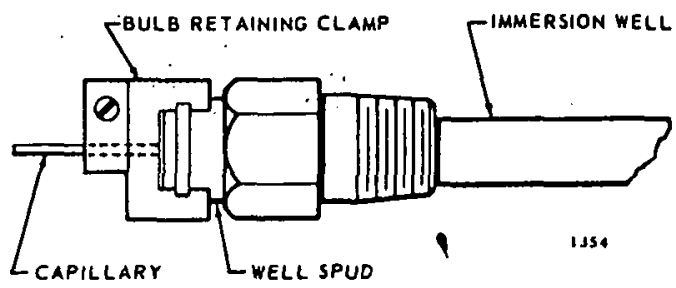

FIG. 8-IMMERSION WELL ASSEMBLY.

To install immersion well:

1. Drain system. Screw the well into properly sized and threaded boiler tapping or pipe fitting.

2. Refill the system and check for leaks.

3. Insert sensing bulb into well until it bottoms.

4. Fit bulb retaining clamp over immersion well flange and capillary tubing, and tighten screw, as shown in Fig. 8.

Coil excess capillary tubing at T991A case.

\section{WIRING}

All wiring must comply with local codes.

Two knockouts are provided at top and bottom of case for $1 / 2$ inch conduit. Follow any wiring instructions furnished with heating or cooling system. In replacement applications, make certain the T991A is wired in the system to operate the same way as old control. Fig. 9 shows typical wiring.

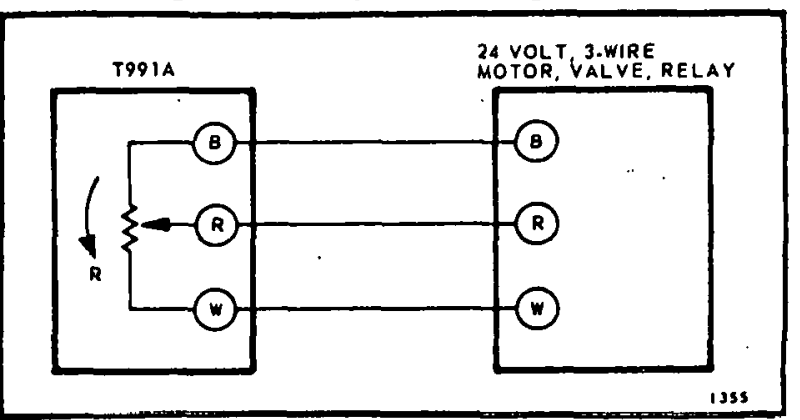

FIG. 9-TYPICAL HOOKUP.

\section{ADJUSTMENTS AND CILECROUT}

TEMPERATURE SETTING: Turn knob on front of case until pointer indicates desired set polnt temperature. This is the center point of the proportional range.

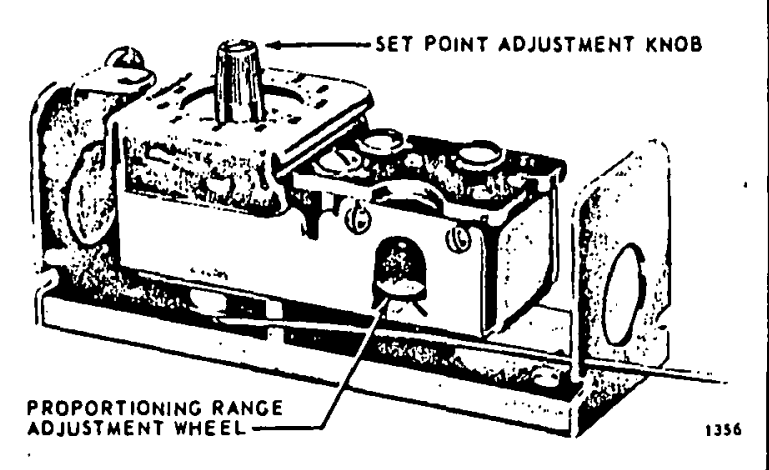

FIG. 10-PROPORTIONING RANGE ADJUSTMENT.
RANGE ADJUSTMENT: The T991A may be adjusted to vary the temperature range within which proportional action is desired. With cover off, turn adjustment wheel until pointer indicates desired range.

Example: If the temperature of the controlled medium is to be maintained at $130 \mathrm{~F}$, and proportional action from $125 \mathrm{~F}$ to $135 \mathrm{~F}$ (a range of 10 degrees) is desired-turn the temperature set point indicator to $130 \mathrm{~F}$ and the proportional range adjustment wheel to 10 .

\section{CHECKOUT}

After mounting and wiring have been completed, let the controlled equipment operate until system temperature stabilizes (from 1 to 3 hours). Observe the motor action to see if it stabilizes. If the motor shaft constantly moves back and forth, widen the T991A proportional range (about five degrees at a timé) until the system is stable. 


\section{Honeyerel}

THE C773 IS A PLATINUM FILM SENSOR WHICH HAS A POSITIVE TEMPERATURE COEFFICIENT. ON A RISE IN AMBIENT TEMPERATURE THE RESISTANCE OF THE SENSOR INCREASES.

C773A contains a single sensor for storage tank or solar collector mounting.

C773B contains a double sensor for storage tank or solar collector applications.

- C773C contains a single sensor with a flattened end and mounting hole for easy solar collector installation.

U C773D contains a double sensor with a flattened end and mounting hole for easy solar collector installation.

$\checkmark$ Available with a medium or high ambient temperature range (specify when ordering).

- Immersion well and remote sensor wiring compartment available separately.

R.L.

$10-77(.03)$
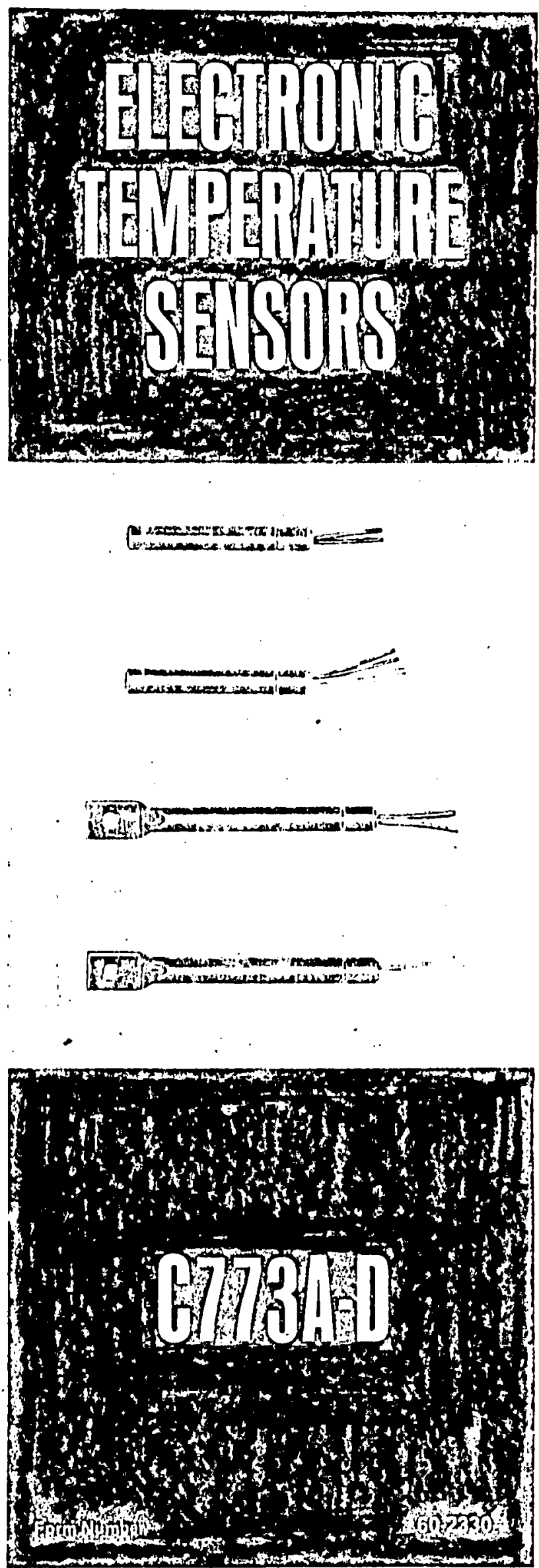
THE SPECIFICATIONS GIVEN IN THIS PUBLICATION DO NOT INCLUDE NORMAL MANUFACTURING TOLERANCES. THEREFORE, THIS UNIT MAY NOT MATCH THE LISTED SPECIFICATIONS EXACTLY. ALSO, THIS PRODUCT IS TESTED AND CALIBRATED UNDER CLOSELY CONTROLLED CONDITIONS, AND SOME MINOR DIFFERENCES IN PERFOR. MANCE CAN BE EXPECTED IF THOSE CONDITIONS ARE CHANGED.

TRADELINE MODELS AVAILABLE:

C773A Temperature Sensor. Single sensor mounts in storage tank using immersion well or on collector with mounting clip.

C773B Temperature Sensor. Double sensor mounts in storage tank using immersion well or on collector with mounting clip.

C773C Temperature Sensor. Single sensor has flattened end with mounting hole for collector installation.

C773D Temperature Sensor. Double sensor has flattened end with mounting hole for collector installation.

LEADWIRE:

C773A,C-two black 18 inch [457.2 mm], No. 22, NEC Class 1.

C773B,D-two black, two white, 18 inch [457.2 $\mathrm{mm}$ ], No. 22 stranded, NEC Class 1.

TEMPERATURE RANGE: Minus 50 to plus $450 \mathrm{~F}$

[minus 46 to plus $232 \mathrm{C}$ ].
DIMENSIONS: See Figs. 2 and 3.

ACCESSORIES:

Immersion Well-for mounting sensor in storage tank. See Table 1 and Fig. 1.

Remote Sensor Wiring Compartment-for wiring storage tank sensor, Part No. 111892F.

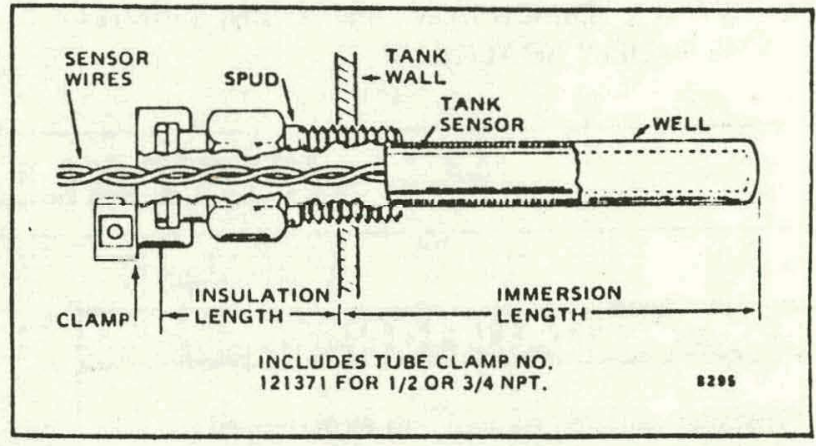

FIG. 1-TANK SENSOR INSERTED IN IMMERSION WELL.

TABLE 1-IMMERSION WELL TABLE

\begin{tabular}{c|c|c|c|c|c|c|c}
\hline \multirow{2}{*}{$\begin{array}{c}\text { IMMERSION } \\
\text { LENGTH }\end{array}$} & \multicolumn{2}{c|}{$\begin{array}{c}\text { INSULATION } \\
\text { LENGTH }\end{array}$} & \multicolumn{4}{c}{$\begin{array}{c}\text { SELECT WELL MATERIAL AND } \\
\text { ORDER NUMBER BELOW }\end{array}$} \\
\cline { 7 - 8 } & in. & $\mathrm{mm}$ & in. & $\mathrm{mm}$ & \multicolumn{2}{|c}{ COPPER } & \multicolumn{2}{c}{ STAINLESS STEEL } \\
\cline { 6 - 8 } & & & $1 / 2 \mathrm{NPT}$ & $3 / 4 \mathrm{NPT}$ & $1 / 2 \mathrm{NPT}$ & $3 / 4 \mathrm{NPT}$ \\
\hline $3 \cdot 3 / 8$ & 85.7 & $1 \cdot 1 / 2$ & 38.1 & $121731 \mathrm{~A}$ & $121371 \mathrm{~B}$ & $121371 \mathrm{E}$ & $121371 \mathrm{~F}$ \\
\hline $3 \cdot 3 / 8$ & 85.7 & $1 \cdot 1 / 2$ & 38.1 & - & $121371 \mathrm{Ka}$ & - & - \\
\hline $3 \cdot 3 / 8$ & 85.7 & 3 & 76.2 & $121371 \mathrm{~L}$ & $121371 \mathrm{M}$ & - & - \\
\hline $3 \cdot 3 / 8$ & 85.7 & 4 & 101.6 & $122554 \mathrm{~A}^{\mathrm{a}}$ & $122555 \mathrm{Aa}$ & - & - \\
\hline $5 \cdot 3 / 8$ & 136.5 & 4 & 101.6 & $122554 \mathrm{Ba}$ & $122555 \mathrm{Ba}^{\mathrm{a}}$ & - & - \\
\hline 6 & 152.4 & $1 \cdot 1 / 4$ & 31.8 & $112620 \mathrm{BB}$ & - & - & - \\
\hline
\end{tabular}

a Has plastic sleeve on insertion well.

continued on page 3

\section{ORDERING INFORMATION}

WHEN PURCHASING REPLACEMENT AND MODERNIZATION PRODUCTS FROM YOUR TRADELINE WHOLESALER OR YOUR DISTRIBUTOR, REFER TO THE TRADELINE CATALOG OR PRICE SHEETS FOR COMPLETE ORDERING NUMBER, OR SPECIFY-

1. Order number.

2. Accessories (immersion well remote sensor wiring compartment).

IF YOU HAVE ADDITIONAL QUESTIONS, NEED FURTHER INFORMATION, OR WOULD LIKE TO COMMENT ON OUR PRODUCTS OR SERVICES, PLEASE WRITE OR PHONE:

1. YOUR LOCAL HONEYWELL RESIDENTIAL DIVISION SALES OFFICE (CHECK WHITE PAGES OF PHONE DIRECTORY).

2. RESIDENTIAL DIVISION CUSTOMER SERVICE

HONEYWELL INC., 1885 DOUGLAS DRIVE NORTH

MINNEAPOLIS, MINNESOTA 55422 (612) $542-7500$

(IN CANADA-HONEYWELL CONTROLS LIMITED, 740 ELLESMERE ROAD, SCARBOROUGH, ONTARIO MIP 2V9) INTERNATIONAL SALES AND SERVICE OFFICES IN ALL PRINCIPAL CITIES OF THE WORLD. 


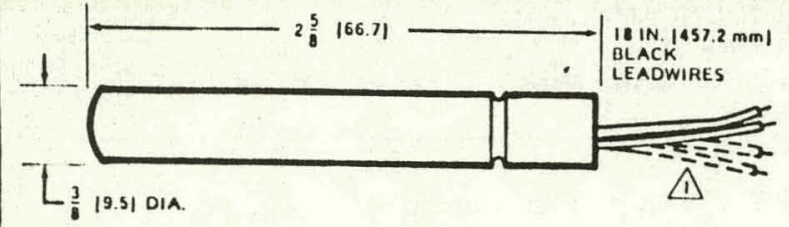

1. 18 IN [457.2 mm] WHITE LEADWIRES ON C7/3B ONLY.
FIG. 2-C773A,B DIMENSIONS IN INCHES IMIL. METRES IN BRACKETS].

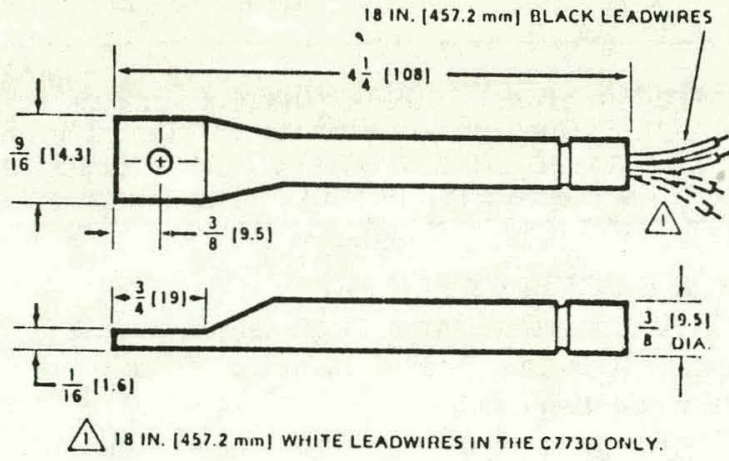

atu

FIG. 3-C773C,D DIMENSIONS IN INCHES [MIL. METRES IN BRACKETS].

\section{INSTALLATION}

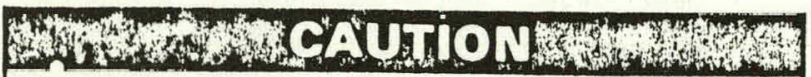

1. Installer must be trained and experienced.

2. Disconnect power supply before connecting wiring to prevent electrical shock or equipment damage.

3. Always conduct a thorough checkout as outlined in the instructions with the primary control when installation is complete.

\section{LOCATION}

Follow the system manufacturer's recommendations for the best location of the sensor. Each sensor should be located so that it experiences the most useful temperature for proper system opcration.

\section{MOUNTING SENSOR}

Mount C773A,B as a storage tank sensor using an immersion well as follows:

1. Drain system fluid to a point below the sensor fitting.

2. Screw the well into the threaded fitting. Use an approved pipe dope or Teflon tape to seal the threads.

3. Refill system and check for leaks.

4. Insert the sensor probe into the immersion well until it bottoms. See Fig. 1.

5. Attach retainer clamp over groove on well spud. Fit wires in clamp groove and lightly tighten screw. Do not overtighten.

Install C773A,B as a collector sensor using the mounting clip provided and No. 8 screw. Mount C773C,D as a collector sensor using the flattened end with mounting hole and a No. 8 or 10 screw.

Temperatures in excess of $450 \mathrm{~F}$ [232 C] will damage the sensor. Shield the sensor against possible overtemperature conditions prior to system operation. Do not mount collector sensor to collector fluid channels.

\section{WIRING}

\section{W}

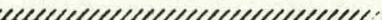

1. Shield the sensor against possible overtemperature conditions prior to system operation.

2. On unglazed collectors mount the sensor with leadwires down to keep sensor from accumulating water.

3. Wire additions to the leadwires must be capable of withstanding a temperature of $450 \mathrm{~F}[232 \mathrm{C}]$.

All wiring must comply with applicable codes and ordinances. The $\mathrm{C773}$ can be used for numerous applications in solar energy systems. Fig. 4 shows the sensors wired to an R7412 Differential Temperature Controller.

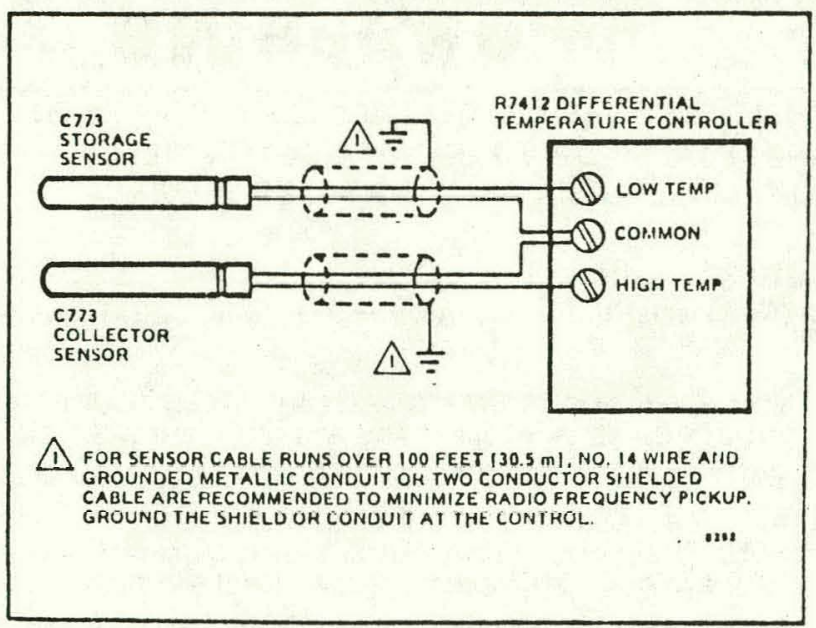

FIG. 4-WIRING C773 TO R7412 DIFFERENTIAL TEMPERATURE CONTROLLER. 
the two black leadwires belong to one sensor and the two white leadwires belong to the other sensor.

If the amount of sensor cable used exceeds 100 feet [30.5 m], use No. 14 wire and grounded metallic conduit or two conductor shielded cable. Connect the shield or conduit to ground at the controller. Grounded metallic alent) minimizes possible radio frequency signal interference.

Remote Sensor Wiring Compartment (Part No. $111892 \mathrm{~F}$ ) is available for tank sensor wiring (see Accessories).

\section{OPERATION AND CHECKOUT}

\section{OPERATION}

The $\mathrm{C} 773$ is a platinum film sensor packaged in a copper capsule. The sensor has a positive temperature coefficient; on a rise in ambient temperature the resistance of the sensor increases (Fig. 5).

\section{CHECKOUT}

Make certain that each sensor is securely mounted. When observing the system in operation, check that the sensors are correctly located. Each sensor should be located so that it experiences the most useful temperature for proper system operation.

To determine the temperature which the sensor is experiencing, use a high resistance ohmmeter $(20,000$ ohm/volt or greater) to measure the resistance of the sensor. This measurement may be converted to a tem. perature reading using Fig. 5 . Check a variety of temperature locations to insure that the sensor reading is providing the most accurate temperature for proper system operation. ?

If the sensors are not providing correct temperature readings because of location, change the location and mount properly.

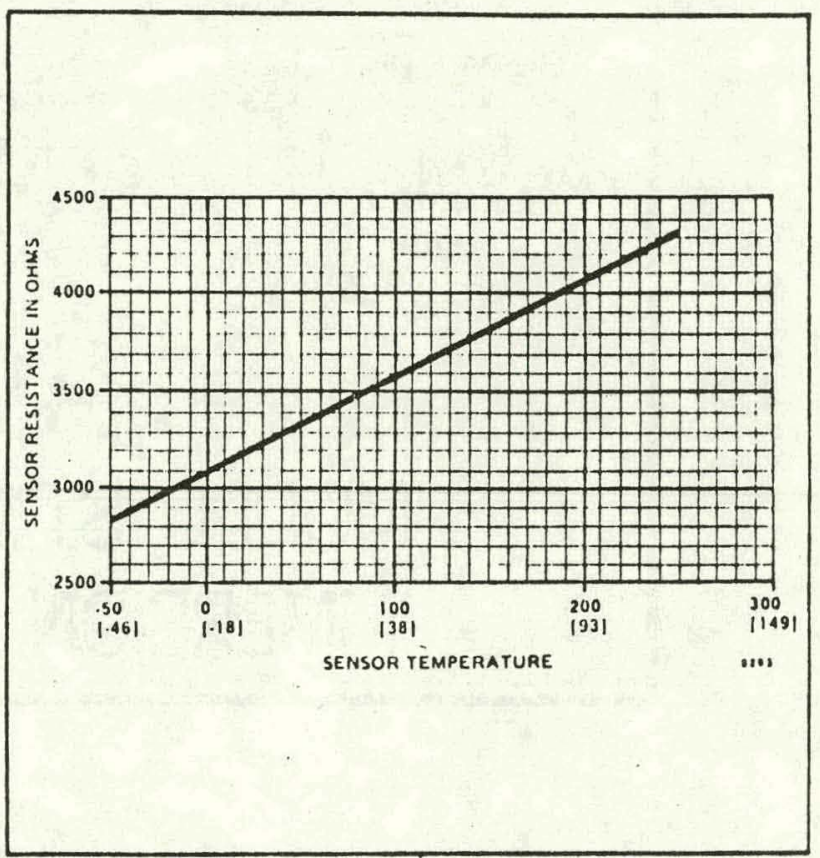

FIG. 5-CONVERTING SENSOR RESISTANCE INTO DEGREES F [C]. 

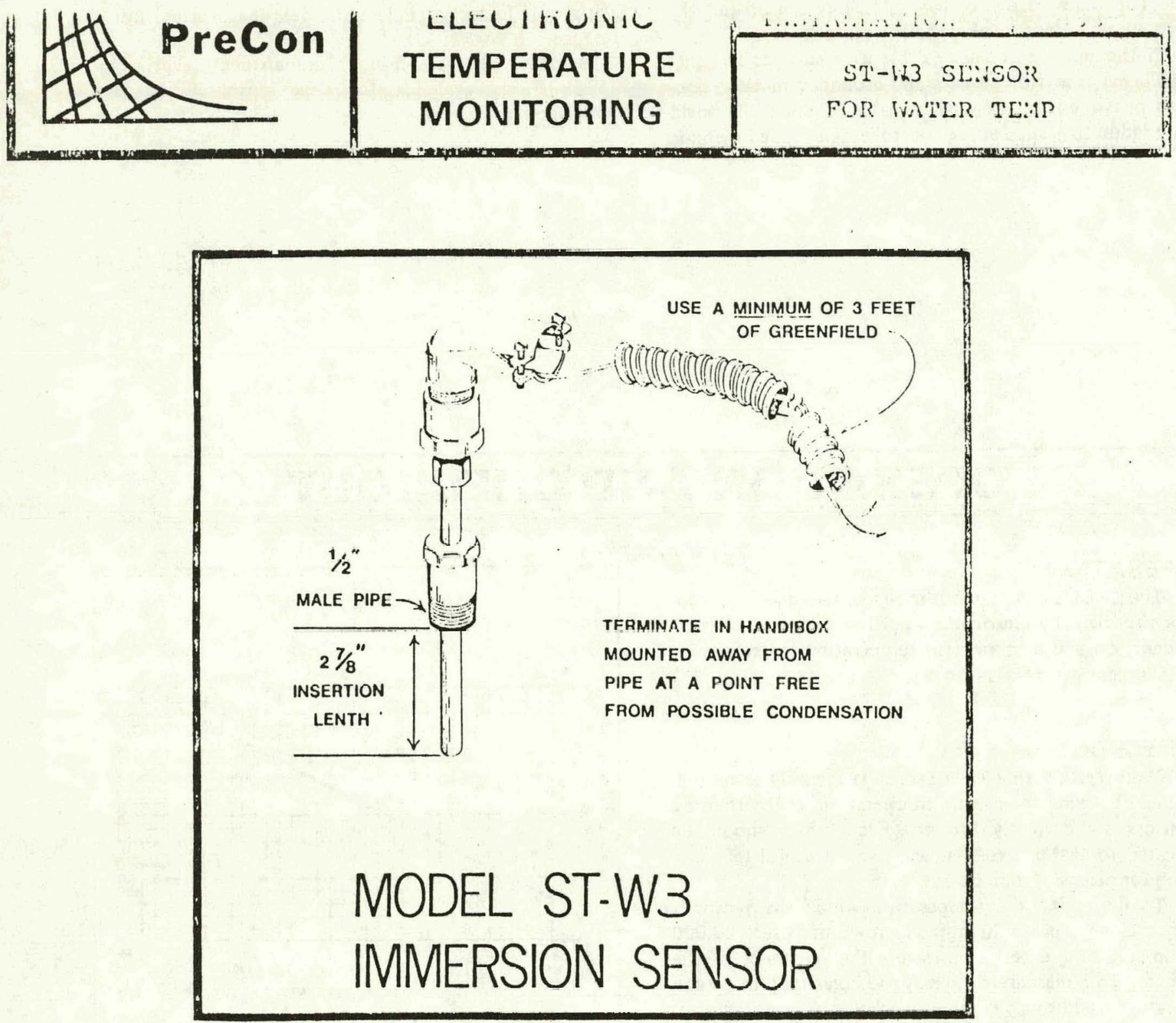

APPLICATION: INUILALIU: OF WNIJE TLYPLRATURL

DLSCRIPTIOA: Prevision lligh Resistance Ihermistor in a brass and copper immersion well with greenfield connector and $7^{\prime}$ wire leads.

l10Uli'IIIG : lount in pipe as shown on job control diagrams. For smaller than 3" locite at a tec or elbow.

PreCon Corporation - 946 Rayner St., Memphis,Tenn. 38114 C- 102 
HIRIIV: Apply no voltage to the sensor. If line voltage is accidentally applied, replace the unit as its accuracy will have been destroyed. 'This high resistance electronic elcment requires solder or crinp type butt splice connections for reliable long term operation. Do not make connections closer than $3^{\prime}$ to the sensing well. Connections must be macie in a box mounted as far as possible from chilled water lines. Any condensation at the point of the splice may cause erroneous (inigh) readings.

\begin{tabular}{|c|c|}
\hline Wire Size & Maximum Run \\
\hline 18 & $3000 \mathrm{Ft}$. \\
\hline 16 & $4750 \mathrm{Ft}$ \\
\hline 14 & $7550 \mathrm{Ft}$ \\
\hline CHART No 1 \\
\hline
\end{tabular}

Chart 1 shows minimum wire size for the run back to the indicating meter. USE S! BLLLST SIZE STRAHDEL WIRE PLRMITTED BY THE CHART. Wiring is class II.

Sensor wiring can be run in the same conduit as other low power control wiring. Do not run sensor wiring with power wiring. For most applications $\$ 182$ conductor rip cord is ideal for sensor wiring. Nake ficld connections according to the job wiring diagrams.

ST-W3 SPECIFICATIONS

RHIGE : $\ldots \ldots \ldots \ldots \ldots \ldots \ldots \ldots 0^{\circ} \mathrm{F}$ to $240^{\circ} \mathrm{F}$

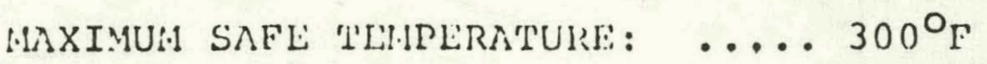

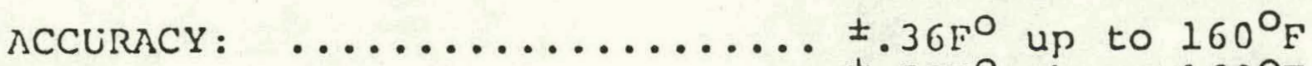

$\pm .52 \mathrm{~F}^{\circ}$ above $160^{\circ} \mathrm{F}$

S'TABILI'Y : $\ldots \ldots \ldots \ldots . \ldots \ldots$ Typical $\pm .1 F^{\circ}$

Maximum $\pm .2 \mathrm{~F}^{\circ}$

REFERLWCL RLSIS'LAINCL: ....... $14.78 \mathrm{~K}$ \& $60^{\circ} \mathrm{F}$

WAIRAIITY: $\quad \ldots \ldots \ldots \ldots \ldots$ Five Years Against Drift or Failure

* Based on a seven year study by the National bureau of standards. 


\section{and \\ STRIP.CHART RECORDER}

\section{RS1008}

The RS1008 operates on the principle that the "short circuit" voltage output of the silicon cell is directly proportional to the radiant input. This principle permits construction of an inexpensive but accurate instrument to measure solar radiation.

The RS1008 is temperature-compensated. The sealed space under the glass dome is connected to a rechargeable desiccant reservoir to ensure dry air conditions. The RS1008 may be conveniently mounted on a photographic-type tripod or on a standard 1/4-20 bolt. It may be leveled with the spring-loaded adjusting screws.

Specifications:

a) Instantaneous response

b) Output approximately $100 \mathrm{MV}$ at $100 \mathrm{Btu} / \mathrm{ft}^{2}-\mathrm{hr}$ solar input

c) Cosine response essentially identical to thermopile pyranometers

d) Temperature compensated to main tain pyranometer within $-2.2 \%$ at $0^{\circ} \mathrm{C}$ (datum point $=30^{\circ} \mathrm{C}$ ) and $+0.8 \%$ at $60^{\circ} \mathrm{C}$ (datum point $=30^{\circ} \mathrm{C}$ )

e) Accuracy within $5 \%$ of daily integrated value of Class 1 instrumentation.

f) Calibration constant and instructions provided with each instrument

g) Weight: Approximately $1 \mathrm{lb}$.

h) Size: 5" diameter $\times 4$ " high

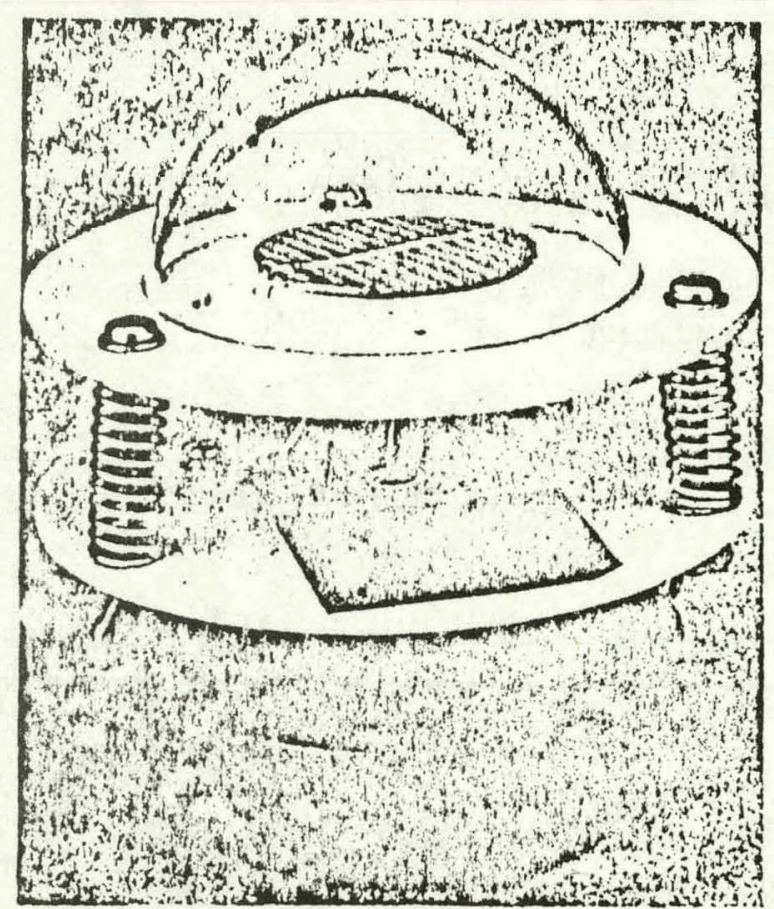

RS 1009

The instrument is designed to provide a historical record of the output of the RS1008 photovoltaic pyranometer. The unit can be calibrated in $B t u / \mathrm{ft}^{2} \cdot \mathrm{hr}$, $W / M^{2}$. Langleys, or other engineering units.

The high output of the silicon cell pyranometer permits direct connection to the recorder without an amplifier. Each recorder is calibrated individually with the pyranometer which accompanies it.

Specifications:

a) Writing speed: 1 strike/ 2 seconds

b) Chart speed. inch/hr

c) Duration of roll: 1 month

d) Accuracy: $\pm 4 \%$ of full scale

e) Input power: 120 VAC

f) Weight: Approximately 3 lbs.

g) Size: $5 \frac{1}{2}$ " deep $\times 4 \frac{1}{2}$ " high $\times 3 \frac{1}{2}$ " wide

A full set of wiring instructions and recorder operations is provided with each unit.

NOTE: The RS1008 (photovoltaic pyranometer) and the RS1009 (strip chart recorder) can be purchased either as a packarge or separately.

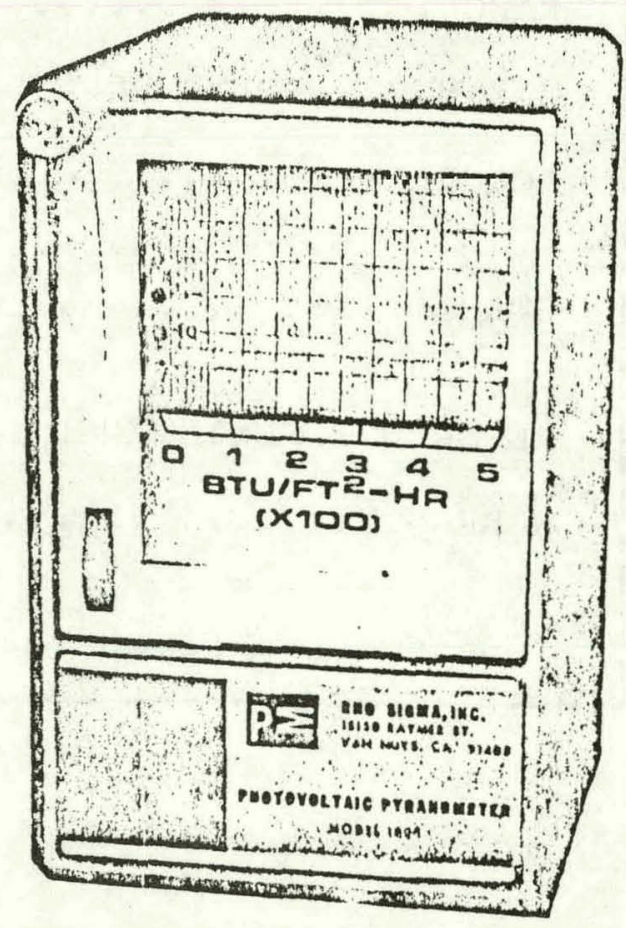


APPENDIX D

PROJECT DRAWINGS

D-1 
HEAT EXCHANGERS

$\sum_{2 x=0}^{2}$ man

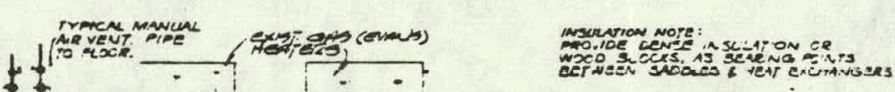

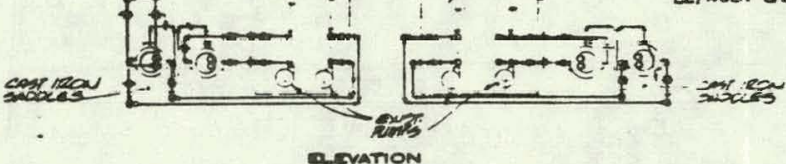

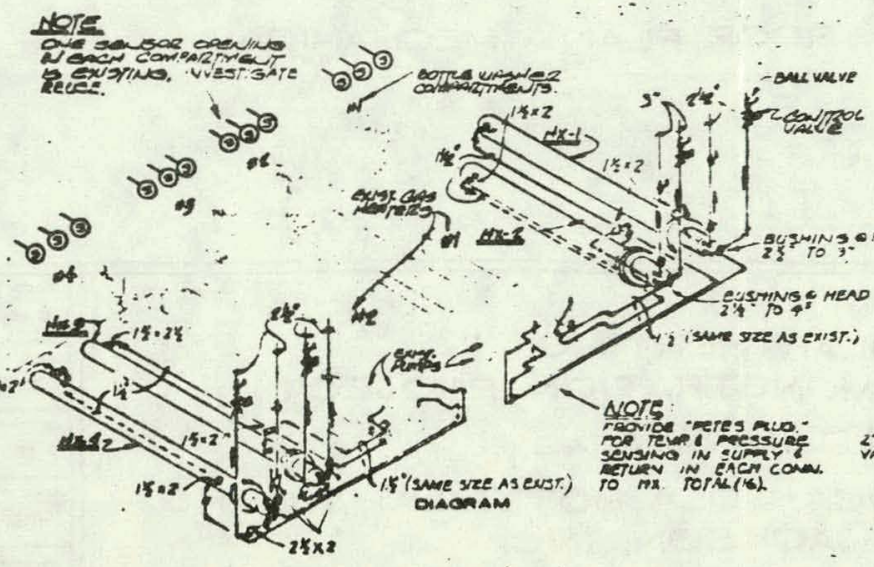

DOTTLE
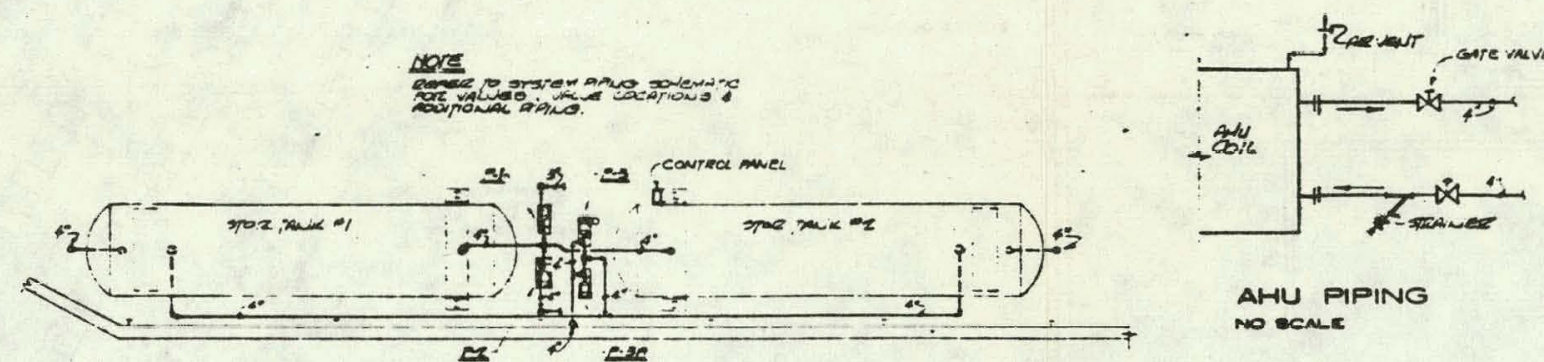

AHU PIPING

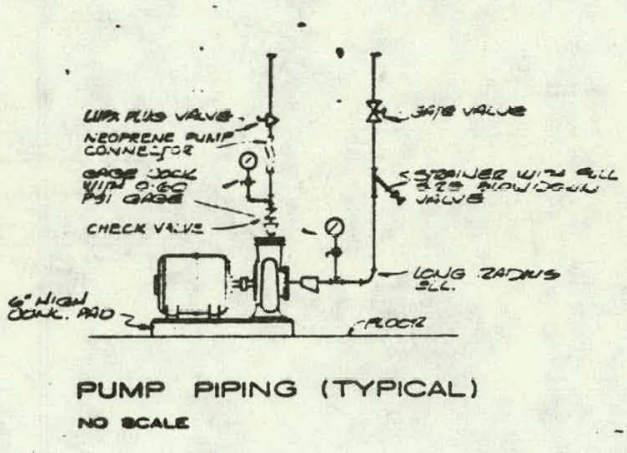

PAFT FLOOR PLAN - MECHANICAL f
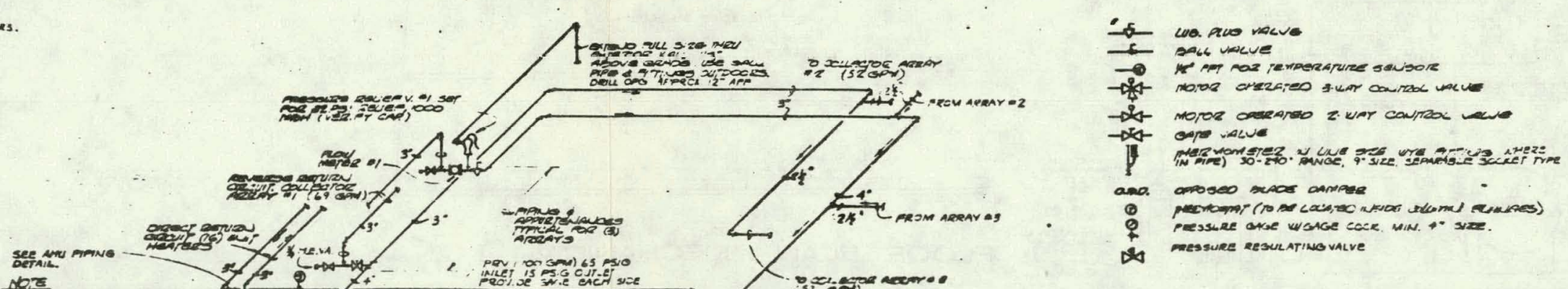


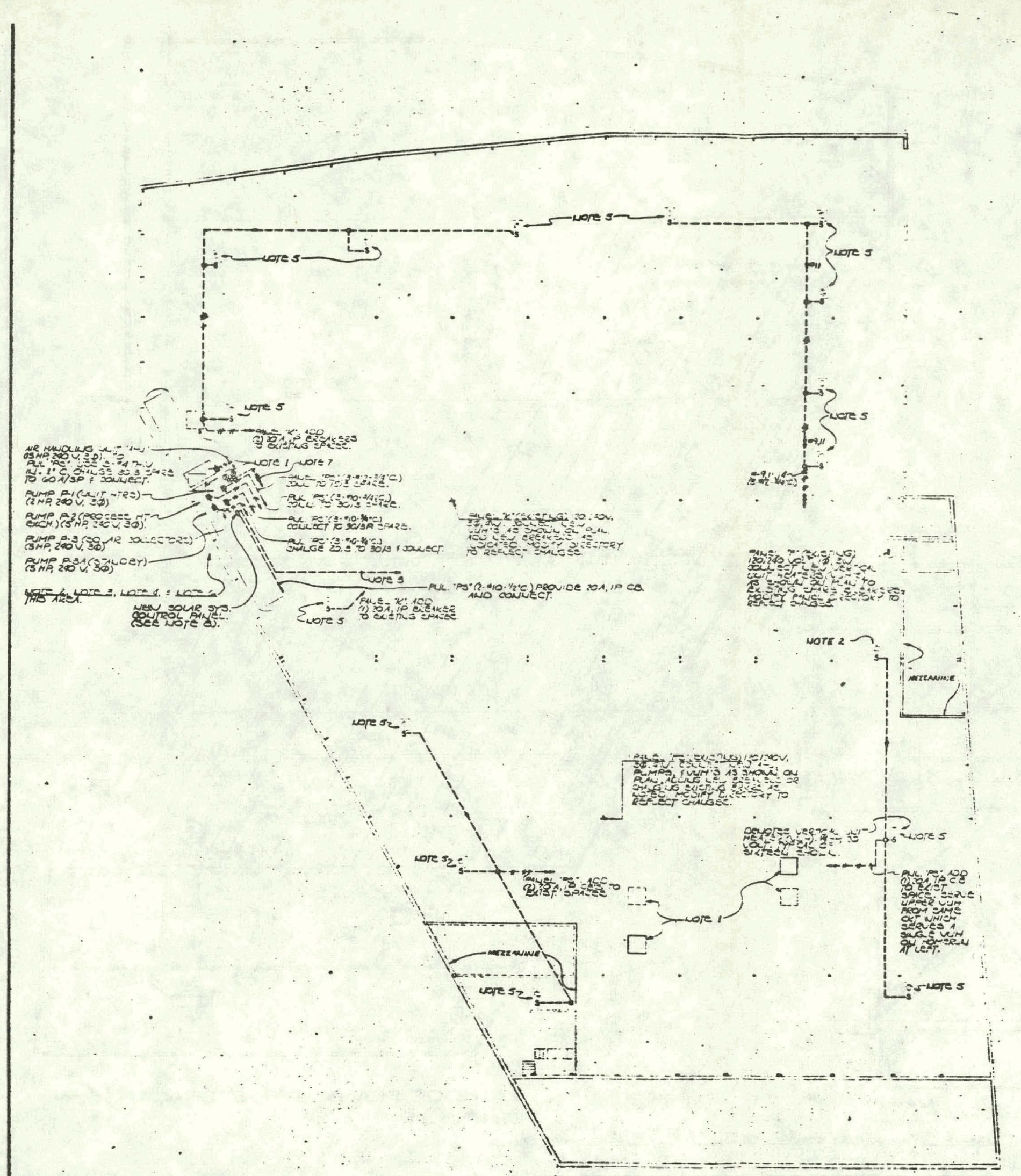

FLOOR PLAN - ELECTRICAL

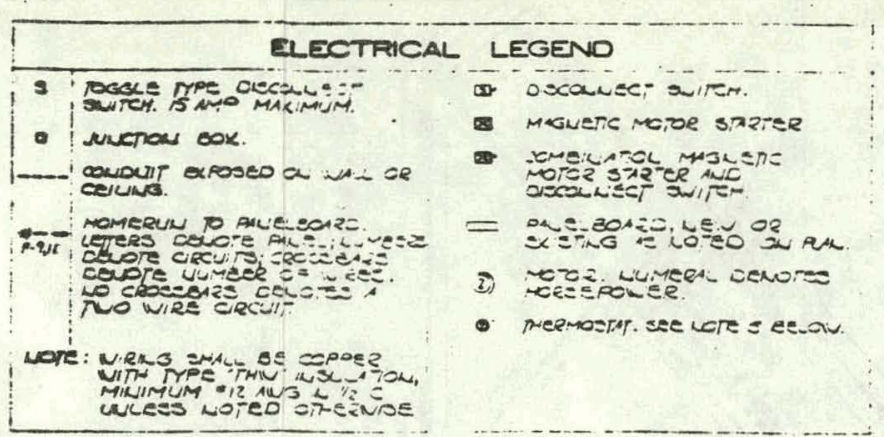

\section{ELECTRICAL NOTES}

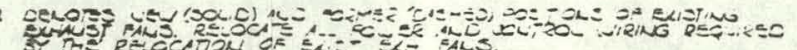

2.

$=4$

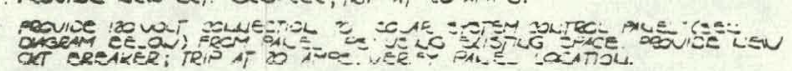

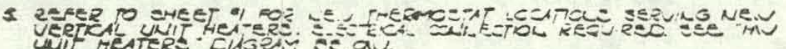

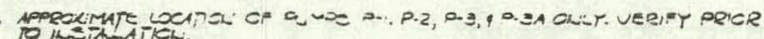

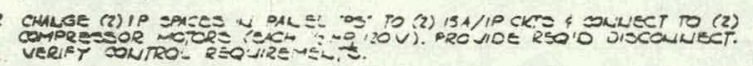

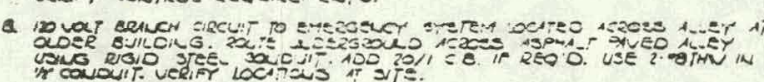
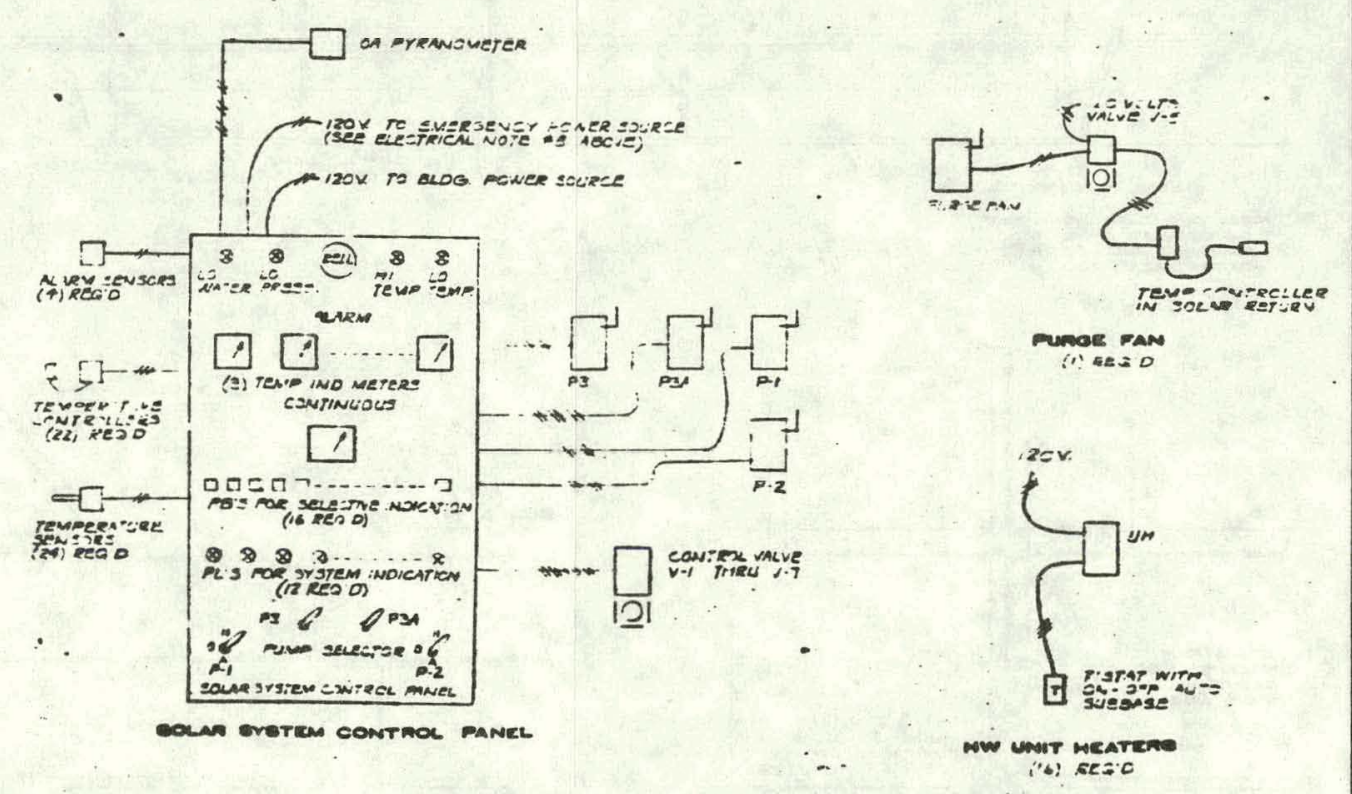

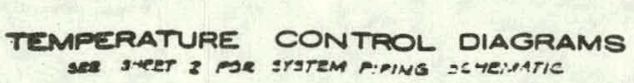

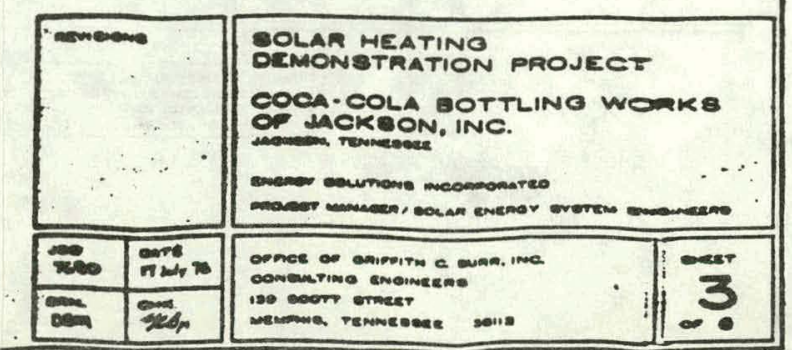




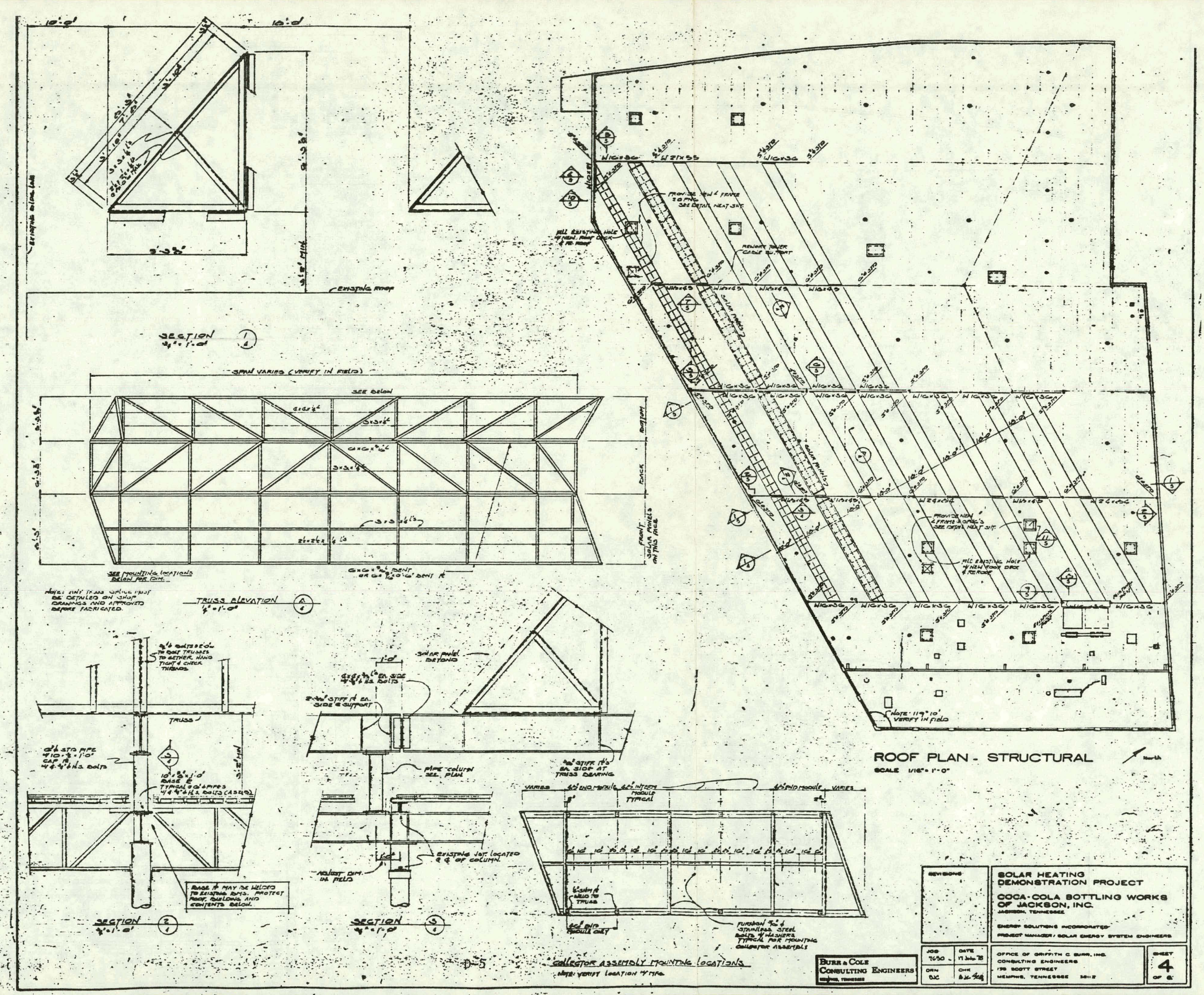




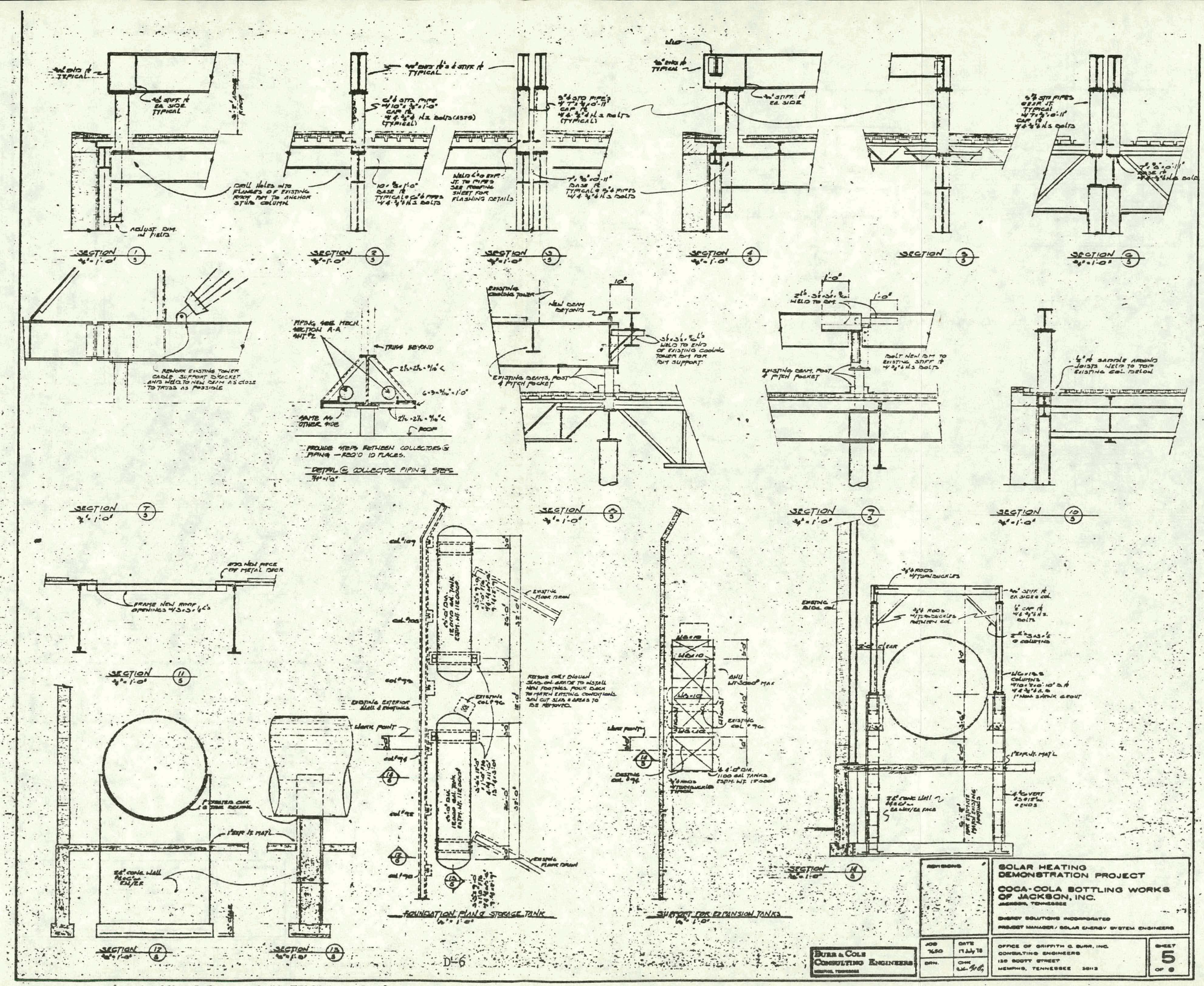




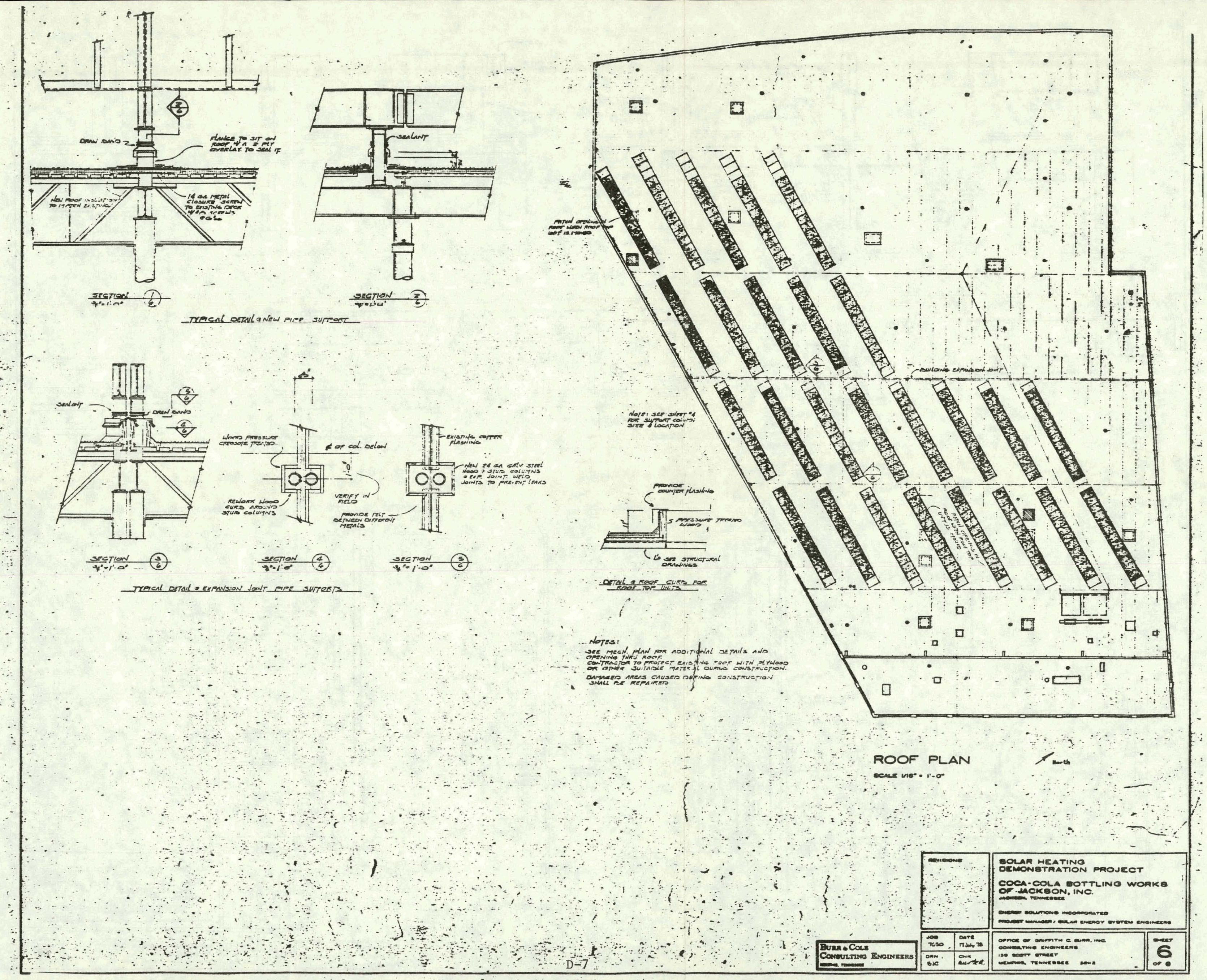




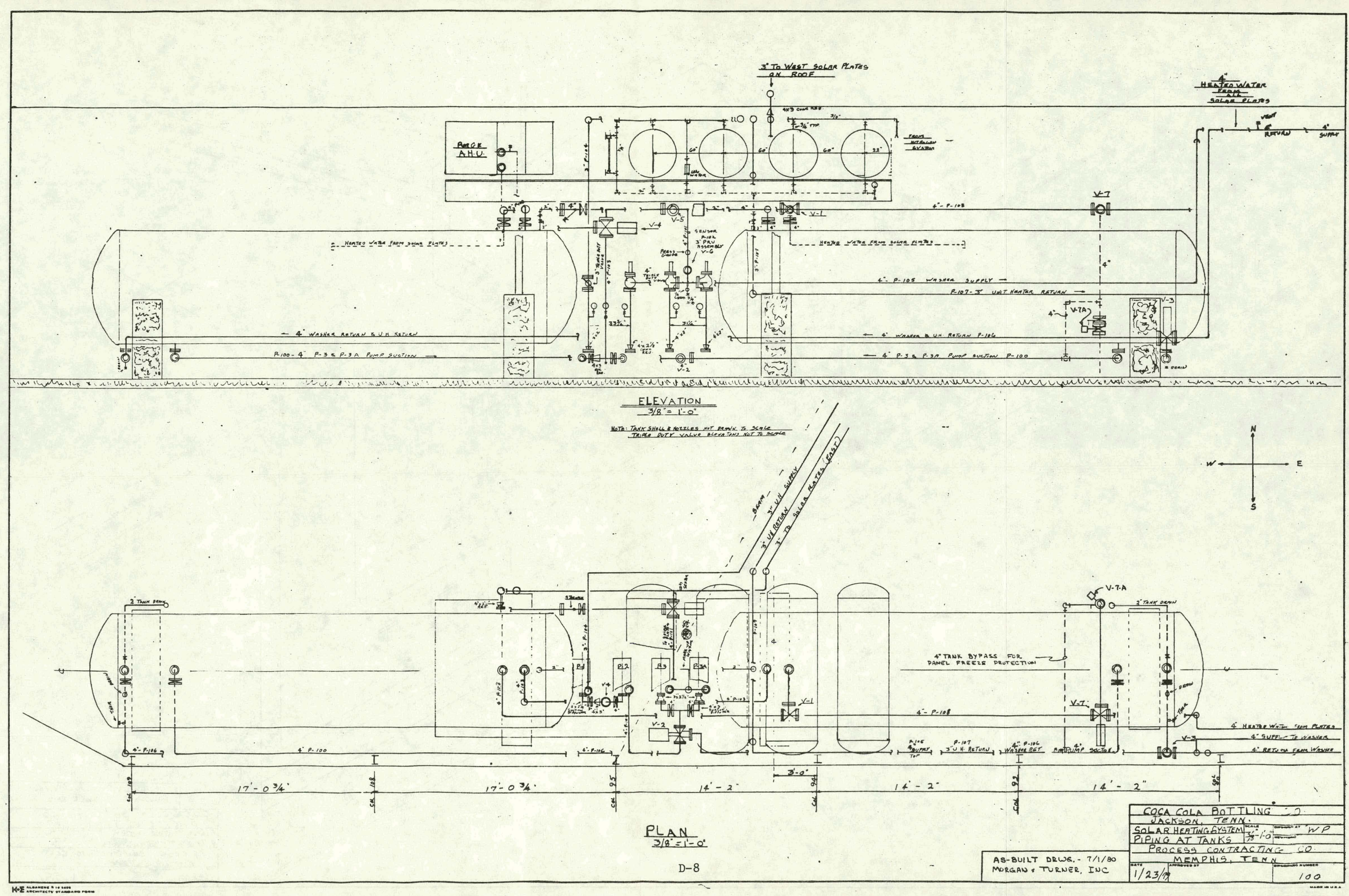




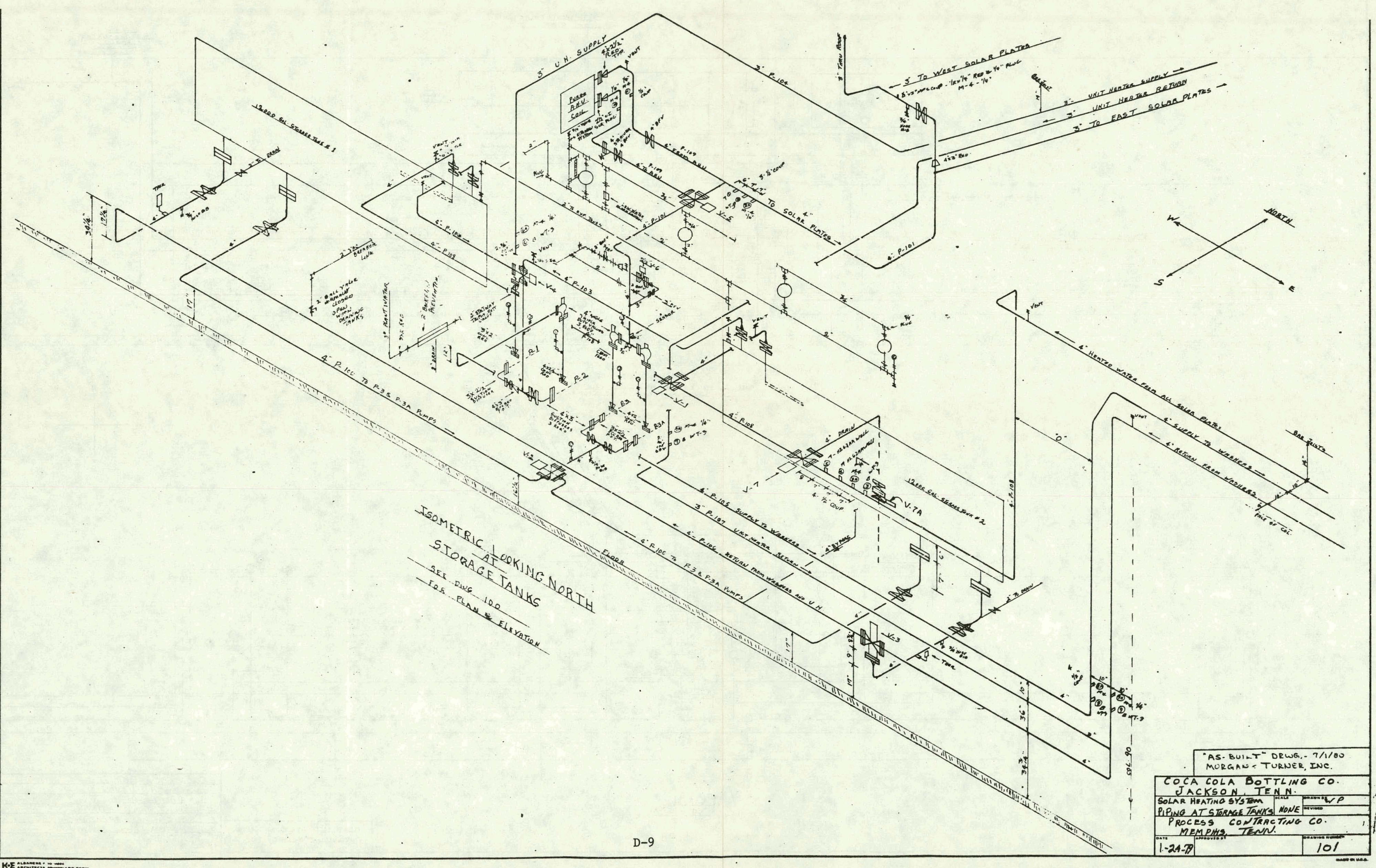




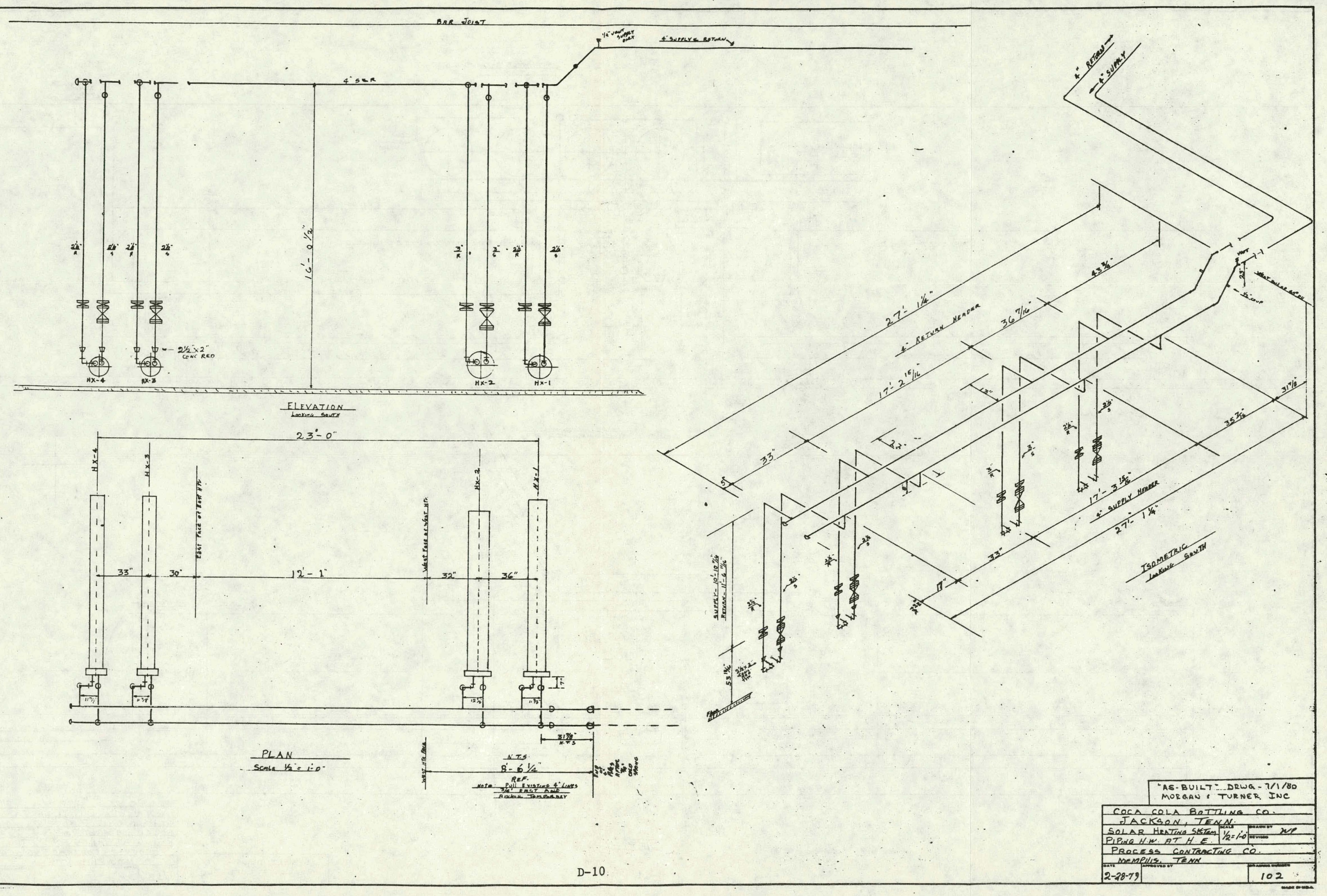




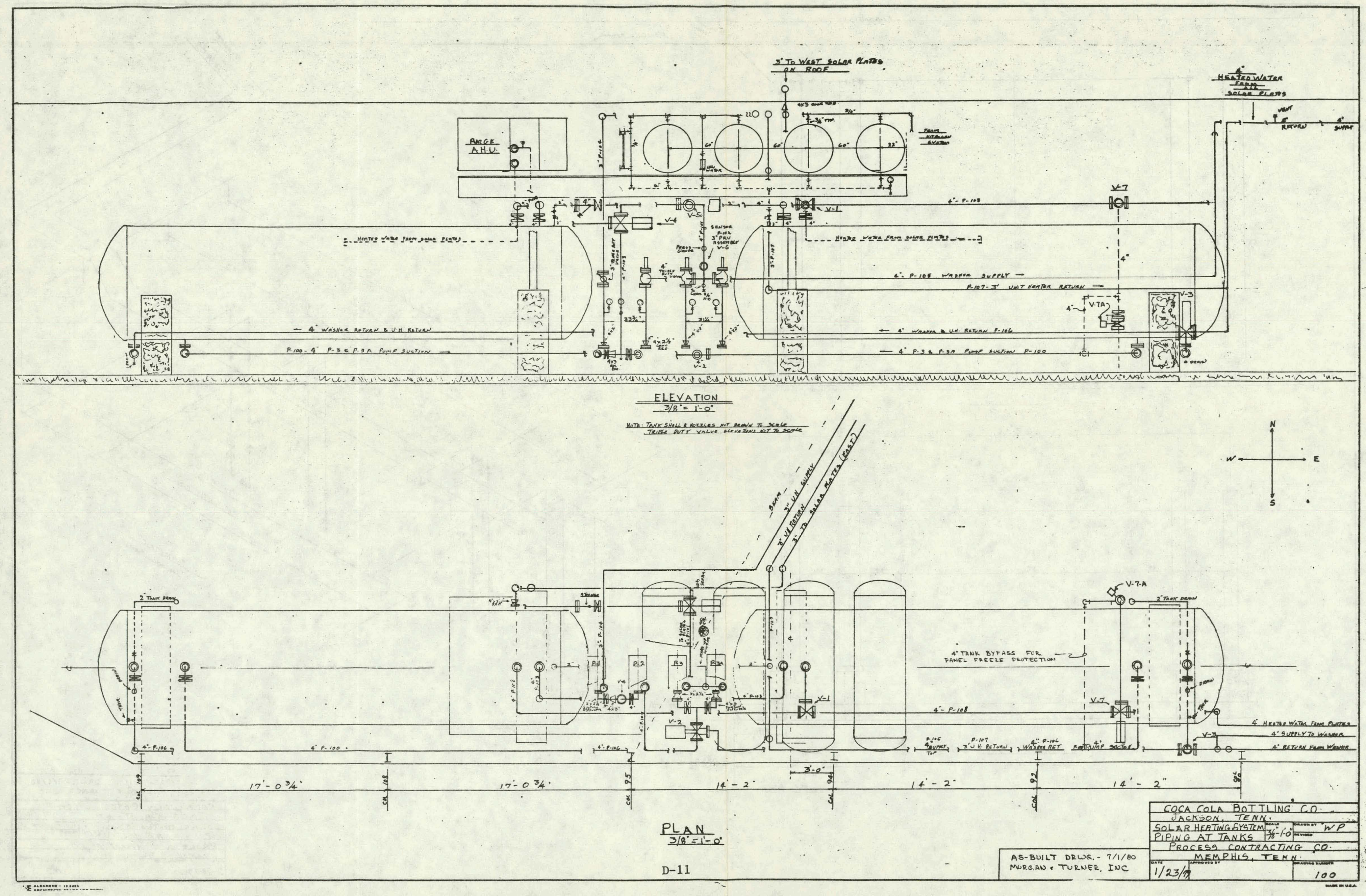




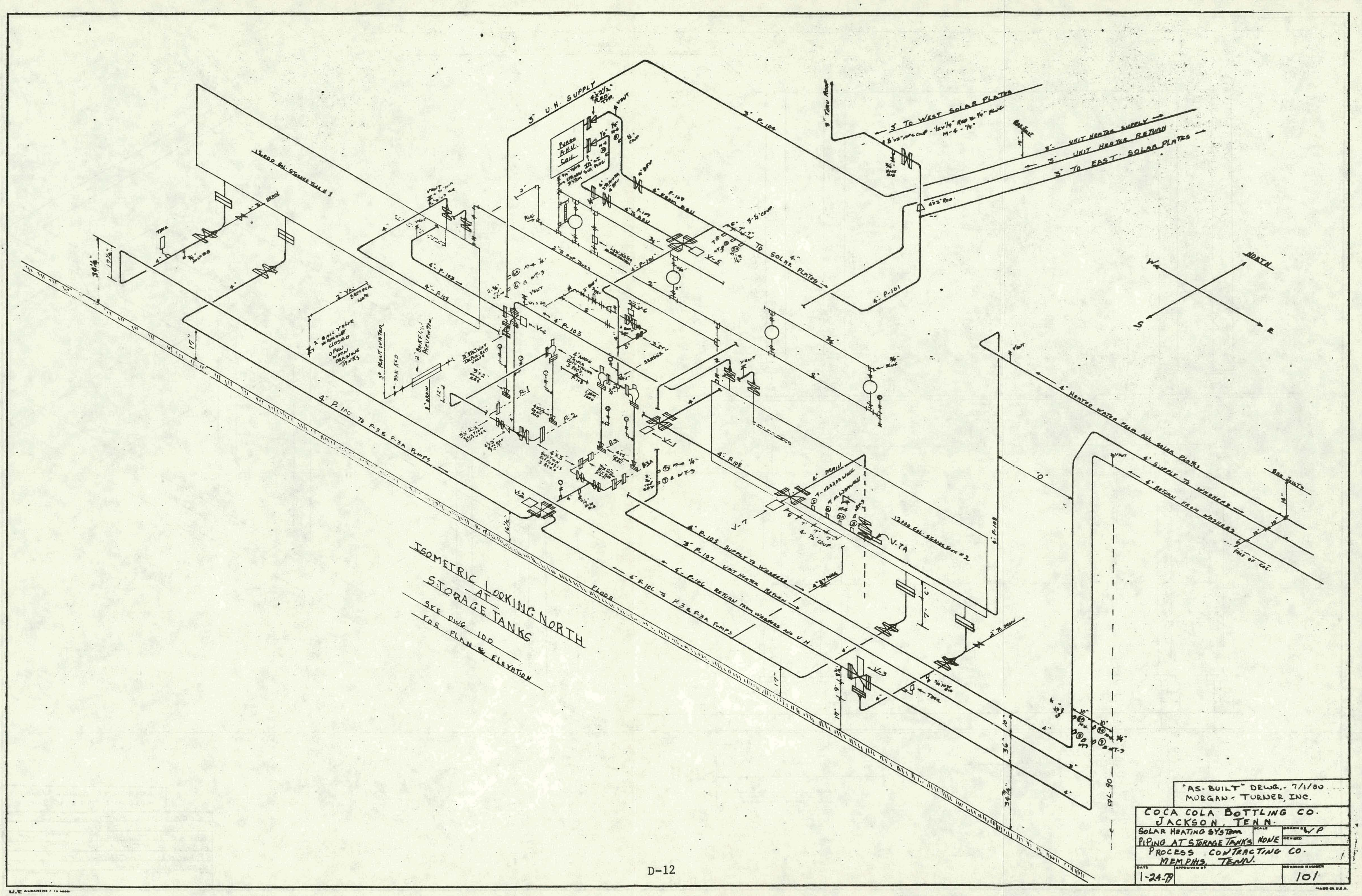




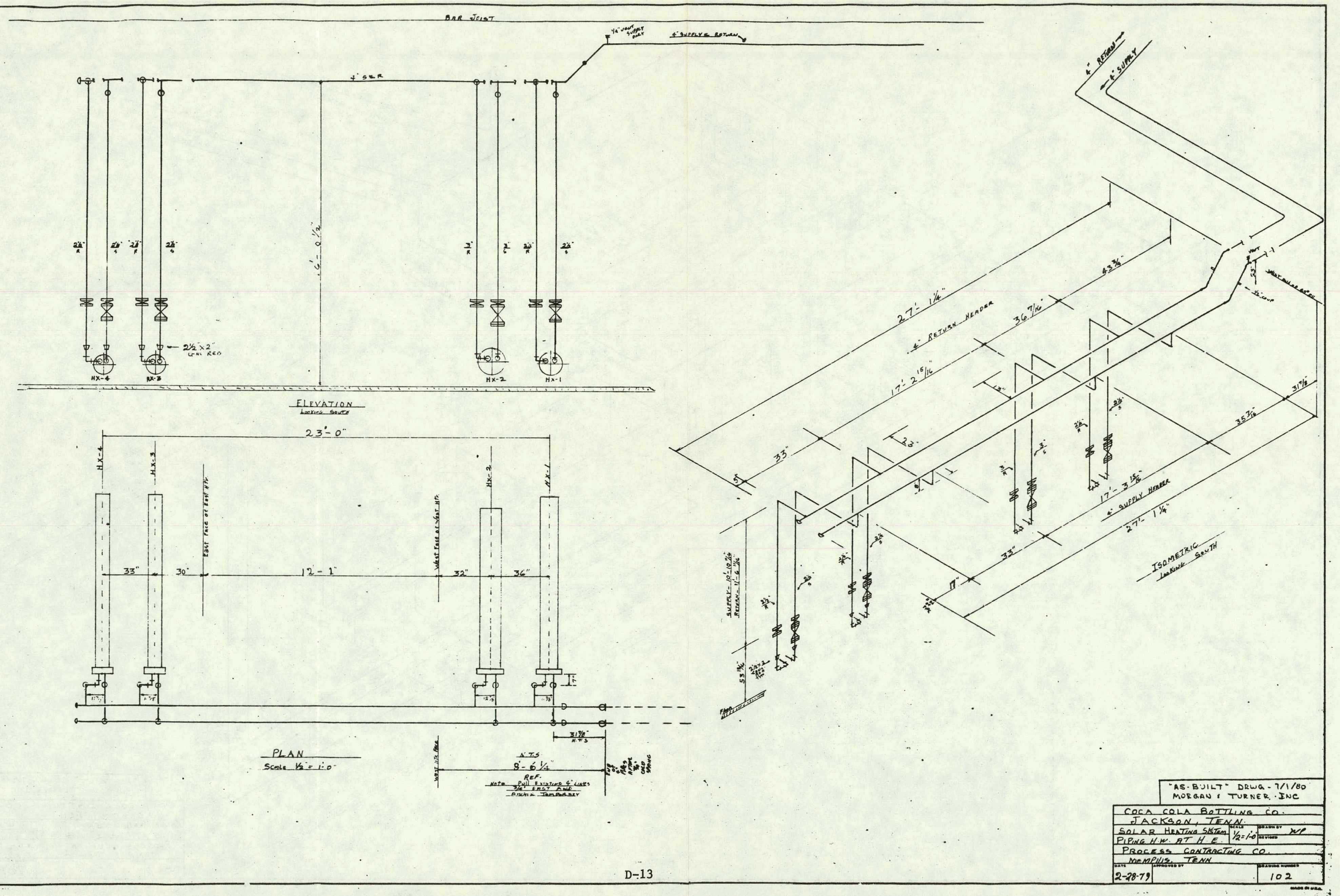




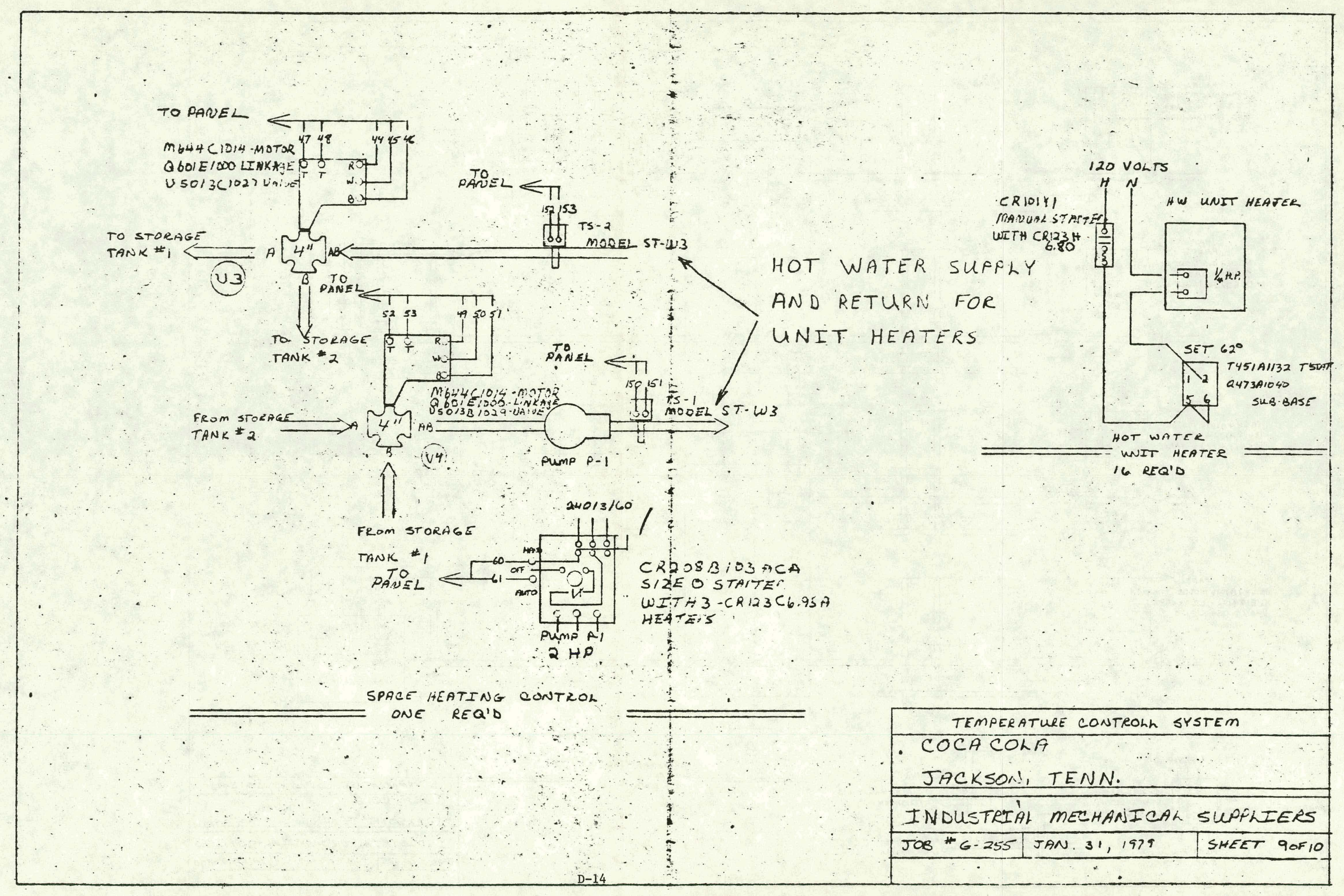




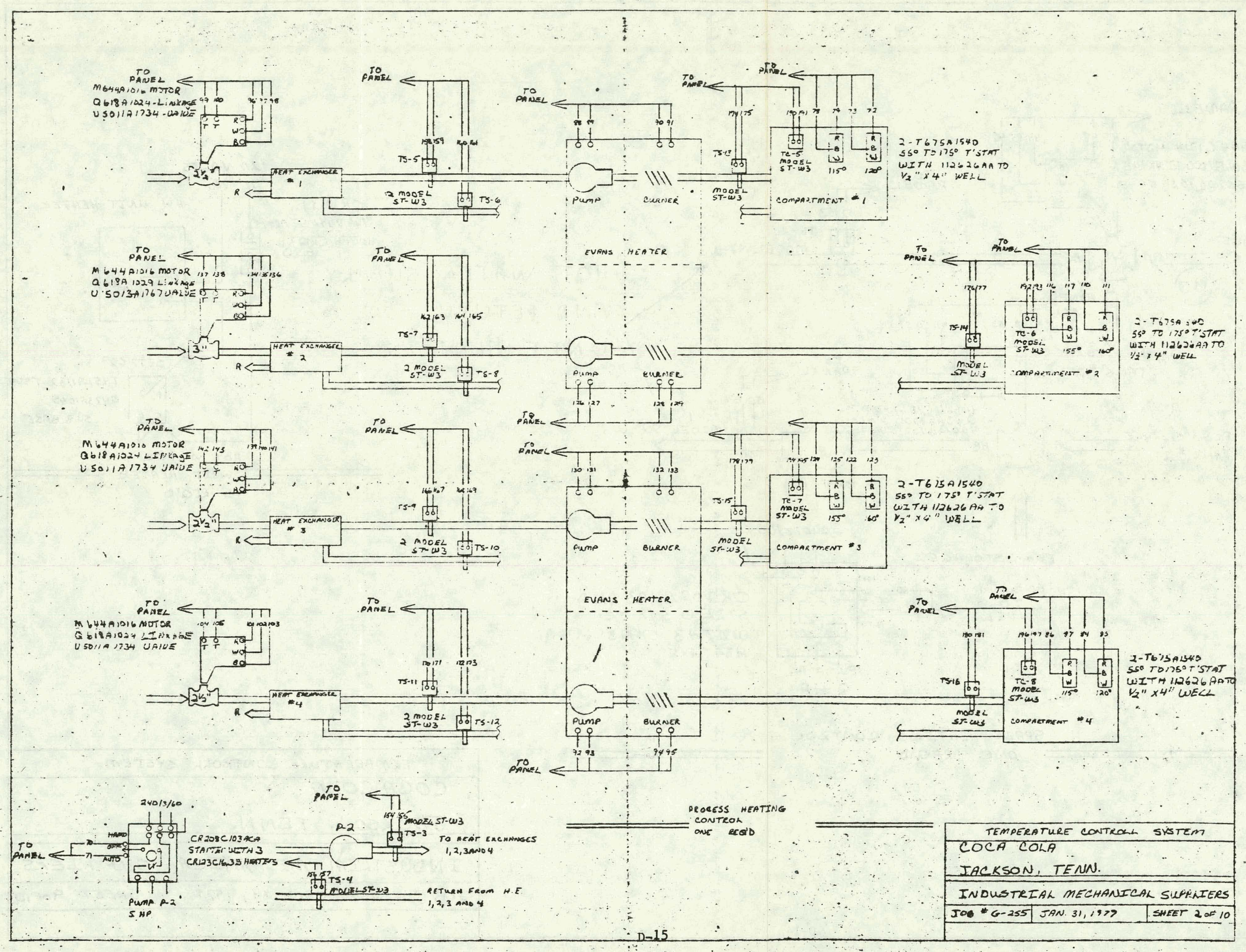




\section{COATraO gBovence}

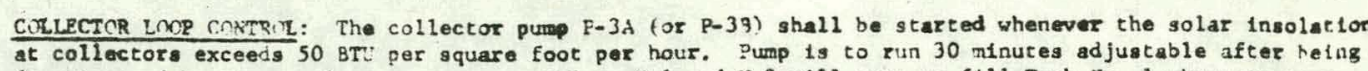

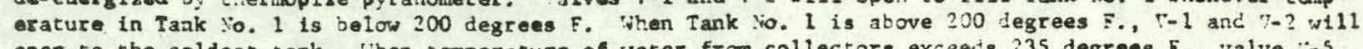
opent to the coldese tank. When tamperature of water from collectors exceats

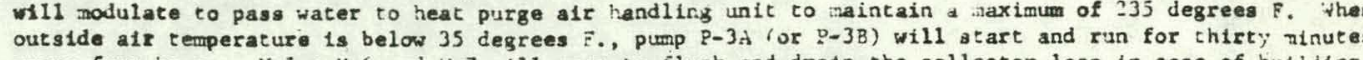

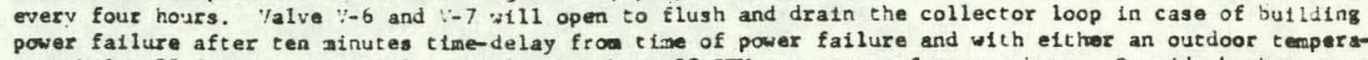

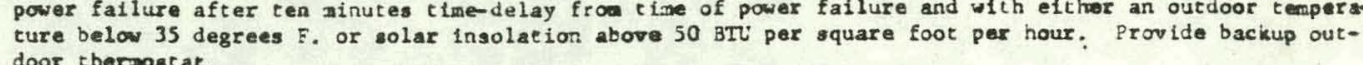

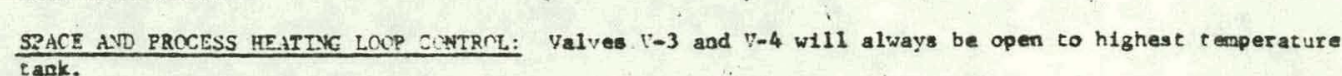

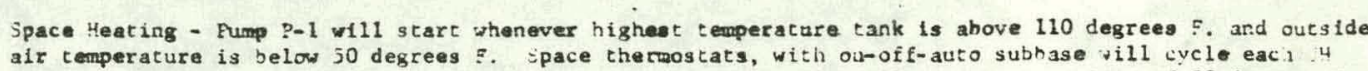

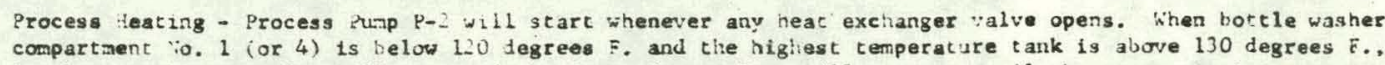
its heat exthanger valve will open and the vans teater Pump will operate unt t1 the compar ment temperaerature tank is below 160 degrees $F$, the gas burner will be energized until the compartment cemperature

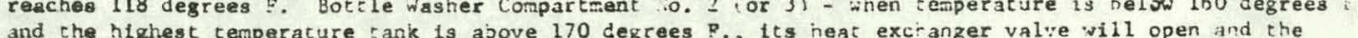

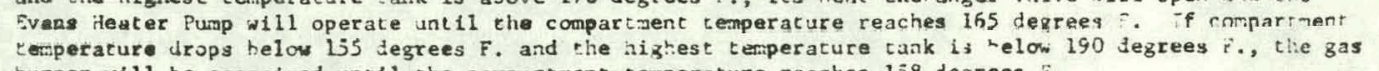

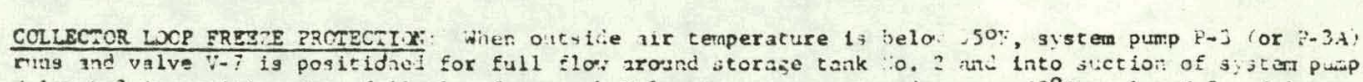

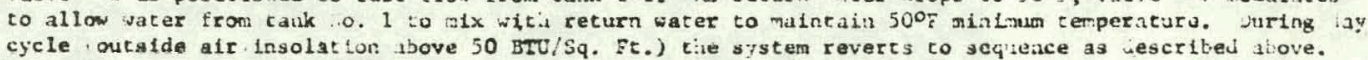

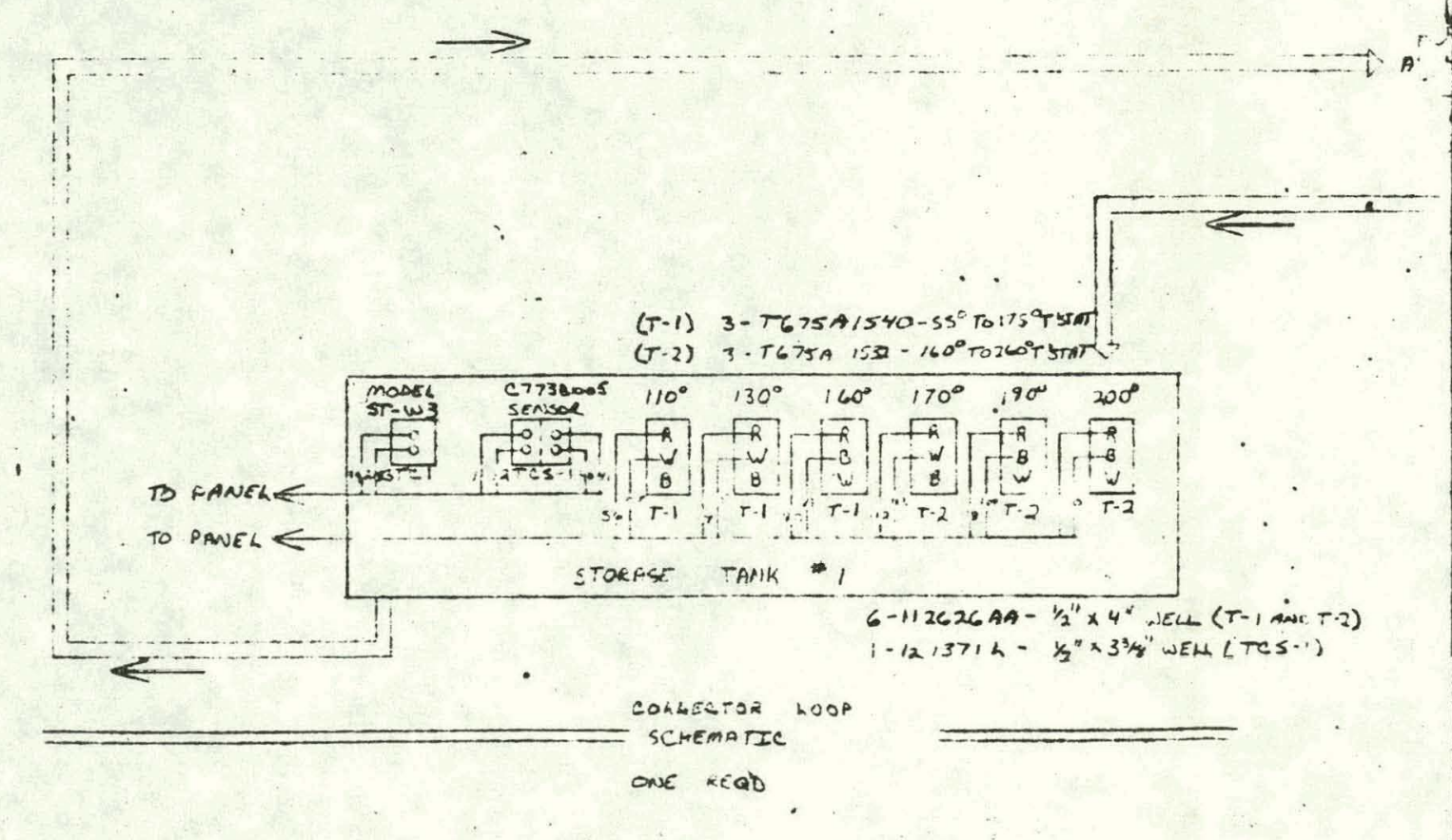

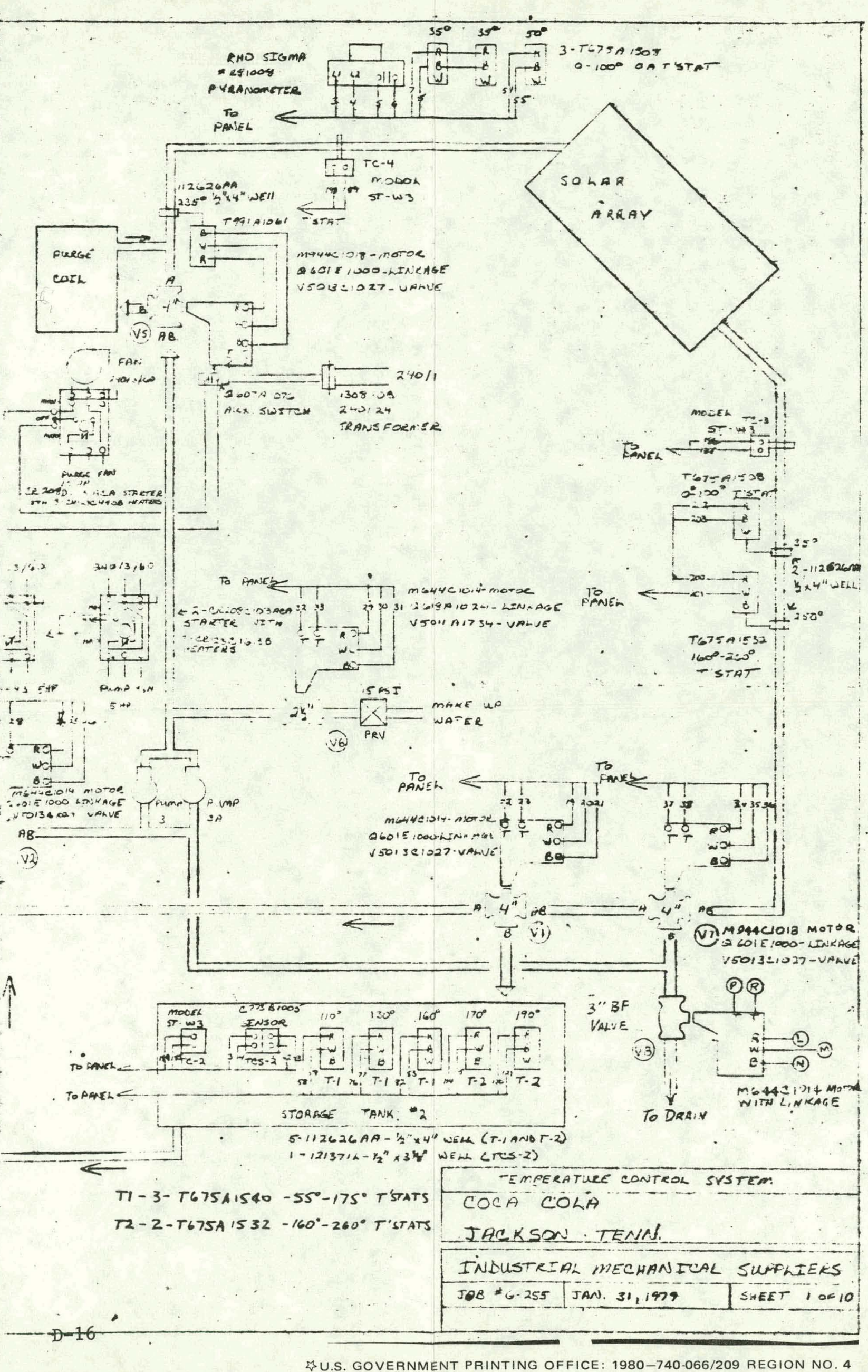

27. U.S. GOVERNMENT PRINTING OFFICE: 1980-740-066/209 REGION NO. 4 